\title{
Effects of a Cattail Wetland on Water Quality of Irondequoit Creek near Rochester, New York
}

\section{U.S. GEOLOGICAL SURVEY}

Water-Resources Investigations Report 00-4032

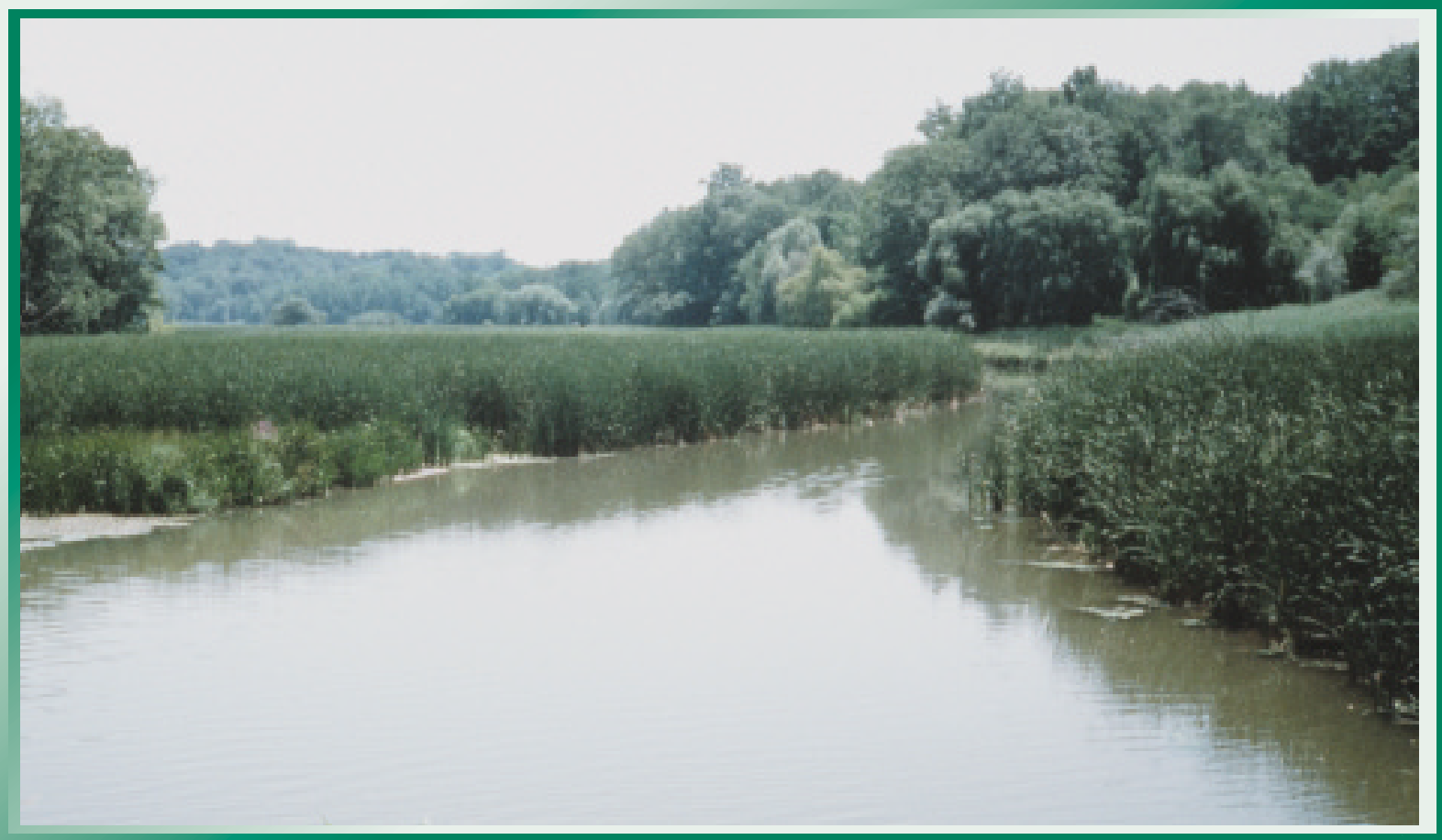

Prepared in cooperation with the MONROE COUNTY DEPARTMENT OF HEALTH 


\section{Effects of a Cattail Wetland on Water Quality of Irondequoit Creek near Rochester, New York}

By WILLIAM F. COON, JOHN M. BERNARD, AND FRANZ K. SEISCHAB

U.S. GEOLOGICAL SURVEY

Water-Resources Investigations Report 00-4032

Prepared in cooperation with the MONROE COUNTY DEPARTMENT OF HEALTH

Ithaca, New York 2000 


\title{
U.S. DEPARTMENT OF THE INTERIOR \\ BRUCE BABBITT, Secretary
}

\author{
U.S. GEOLOGICAL SURVEY
}

Gordon P. Eaton, Director

The use of trade, product, or firm names in this report is for identification or location purposes only and does not constitute endorsement of products by the U.S. Geological Survey, nor impute responsibility for any present or potential effects on the natural resources of the United States.

For addtional information write to:

\section{Subdistrict Chief}

U.S. Geological Survey

30 Brown Road

Ithaca, NY14850
Copies of this report can be purchased from:

\author{
U.S. Geological Survey \\ Branch of Information Services \\ Box 25286 \\ Denver Federal Center \\ Denver, CO 80225-0046
}




\section{CONTENTS}

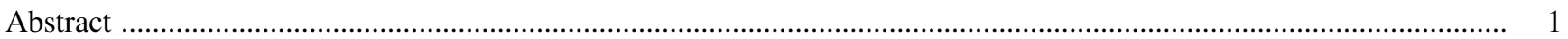

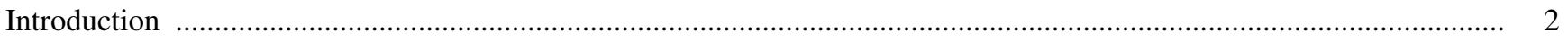

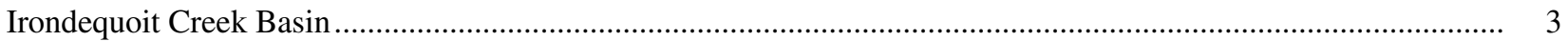

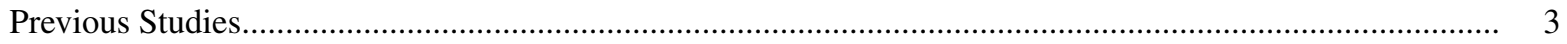

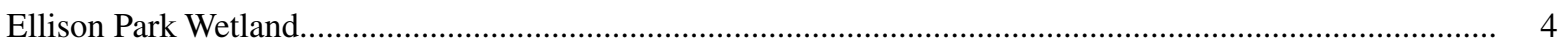

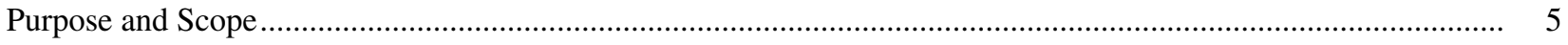

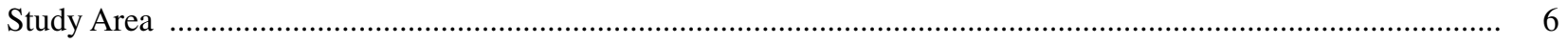

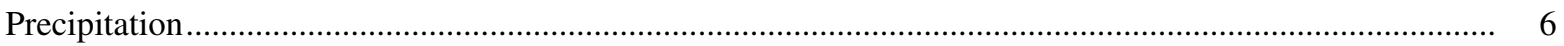

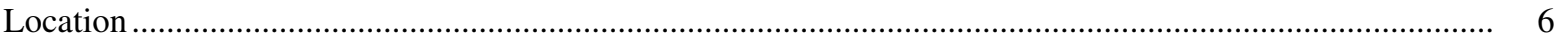

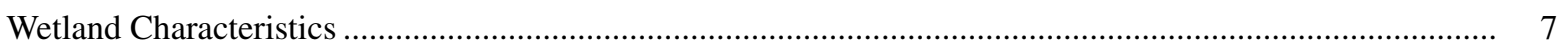

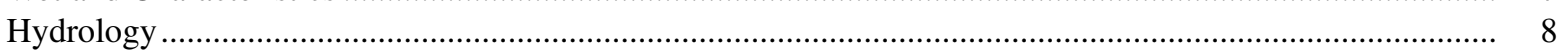

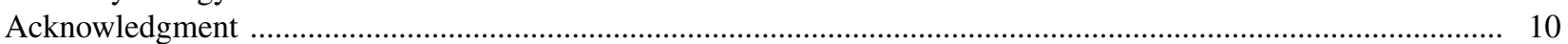

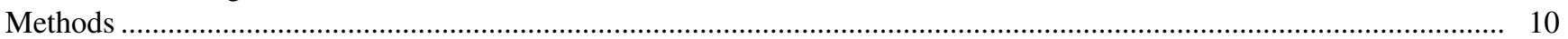

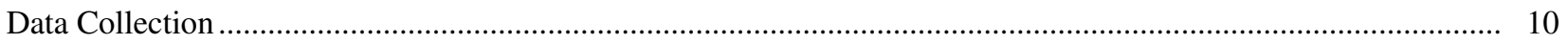

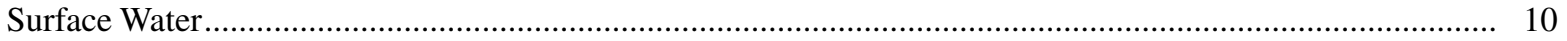

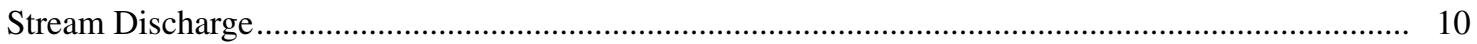

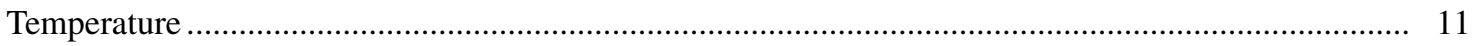

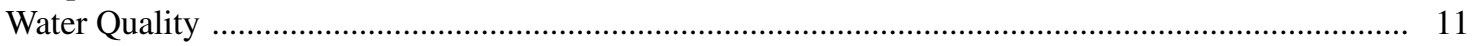

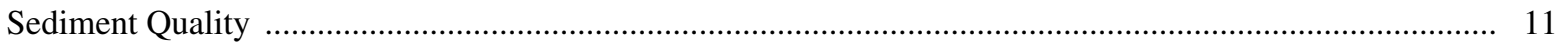

Flora Survey, Plant-Tissue Analyses, and Biomass Measurements............................................................ 11

Quality-Assurance and Quality-Control Program ......................................................................................... 12

Computation of Constituent Loads and Removal Efficiency .......................................................................... 14

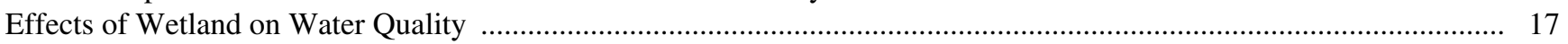

Constituent Loads and Removal Efficiencies ................................................................................................... 19

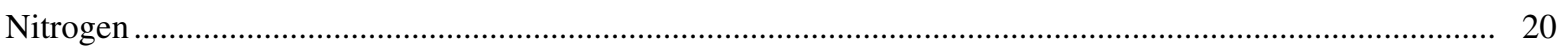

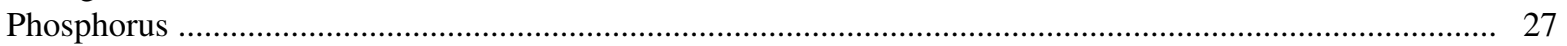

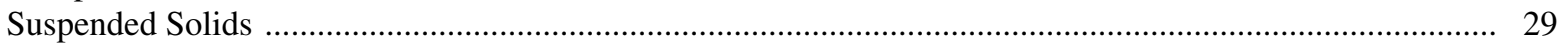

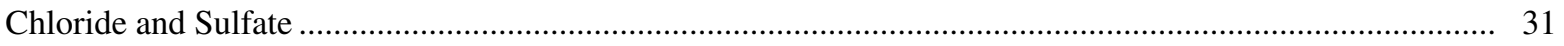

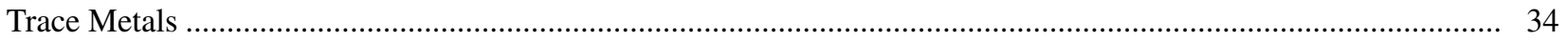

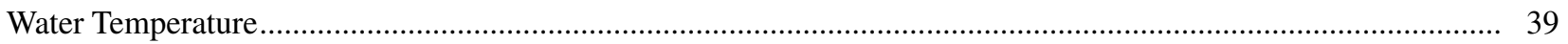

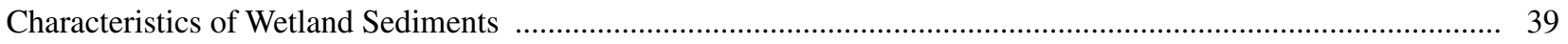

Characteristics of Wetland Vegetation (Typha glauca) ……..................................................................... 41

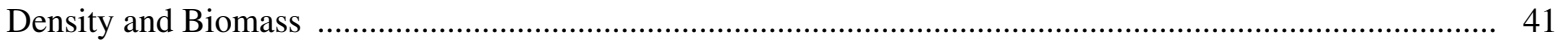

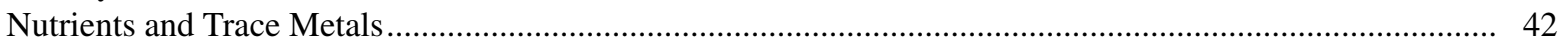

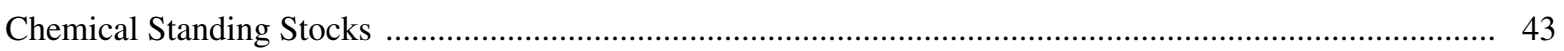

Water-Quality-Improvement Function of Ellison Park Wetland .................................................................. 44

Progress Toward Water-Quality Improvement of Irondequoit Bay …….............................................................. 45

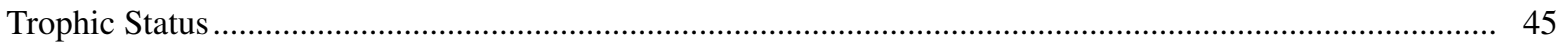

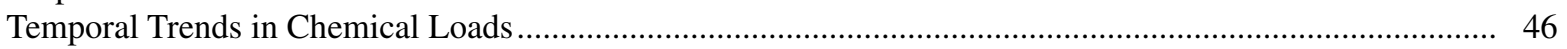

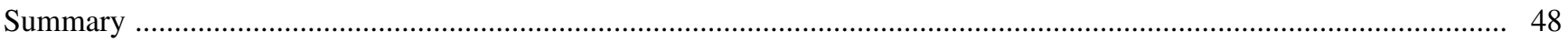

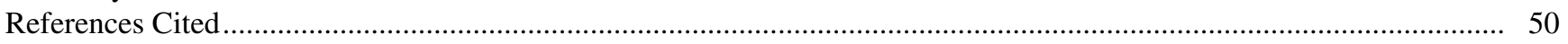

\section{FIGURES}

1. Map showing location of study area and major geographic features of Irondequoit Creek basin, Monroe

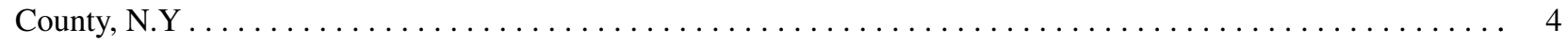

2. Map showing locations of data-collection sites and Ellison Park wetland within the Irondequoit Creek basin,

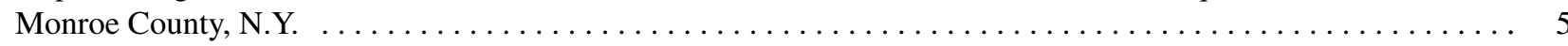


3. Graph showing (A) Monthly precipitation, 1990-96, and normal (1961-90) mean monthly precipitation recorded at the Greater Rochester International Airport, Rochester, N.Y., and (B) Monthly mean discharges at Irondequoit Creek above Blossom Road and at Empire Boulevard, 1990-96, with monthly maximum, mean, and minimum discharges for the period of record at Blossom Road, 1981-96, Monroe County, N.Y. . . . . . . . . . . . . . .

4. Graph showing daily mean water-surface elevation of Ellison Park wetland as measured at Empire

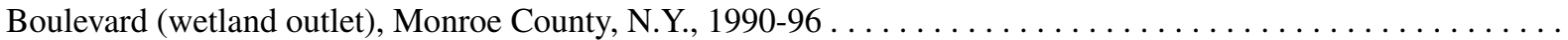

5. Graph showing concentration of (A) a dissolved constituent (ammonia nitrogen), and (B) a particulate constituent (total phosphorus) as a function of discharge in Irondequoit Creek above Blossom Road and at Empire Boulevard,

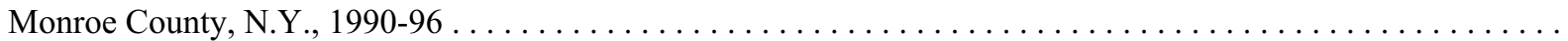

6. Graphs showing monthly load and wetland's removal efficiency for total nitrogen, Ellison Park wetland, Monroe County, N.Y., 1990-96

7-15. Graphs showing concentrations, monthly loads, and wetland's removal efficiency for selected constituents, Ellison Park wetland, Monroe County, N.Y., 1990-96

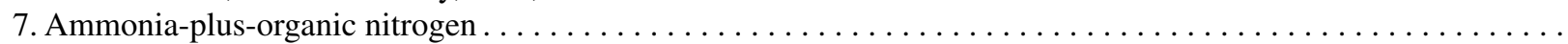

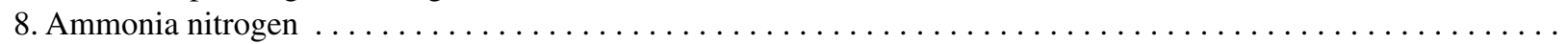

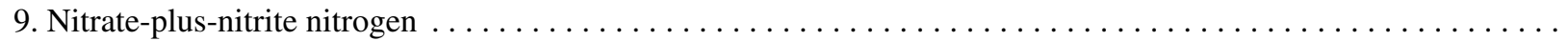

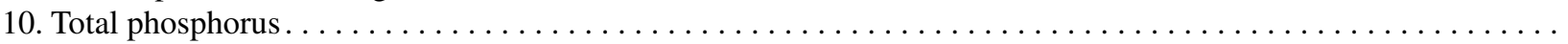

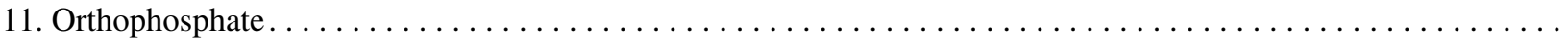

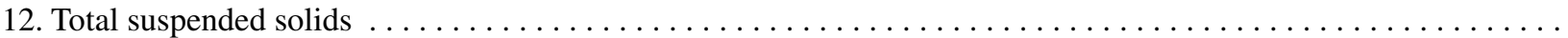

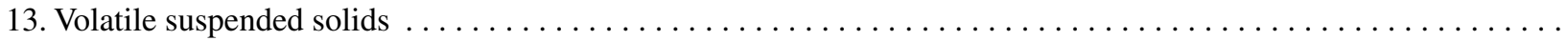

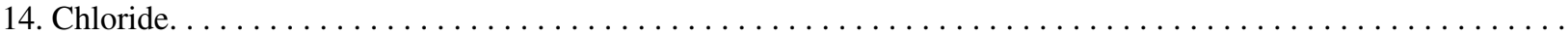

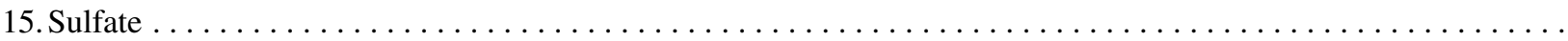

16. Box plots showing concentrations of selected trace metals in stormwater samples from Irondequoit Creek above Blossom Road and at Empire Boulevard, Monroe County, N.Y., 1990-96 . . . . . . . . . . . . . . . . . .

17. Graphs showing water temperatures at Irondequoit Creek above Blossom Road and at Empire Boulevard, Monroe County, N.Y.: A. Monthly mean water temperature, 1994-96. B. Daily mean water temperature, 1996 water year. C. Water temperature and D. hydrograph during storm runoff period, June $18-28,1996 \ldots \ldots \ldots \ldots \ldots \ldots$

18. Graph showing trophic state of Irondequoit Bay, 1971-96, based on measured chlorophyll_ $a$ and computed

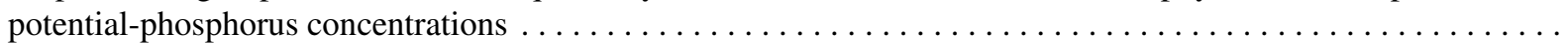

\section{TABLES}

1. Monthly and annual total precipitation recorded at Greater Rochester International Airport, Rochester, N.Y., 1990-96, with normal 30-year (1961-90) means . . . . . . . . . . . . . . . . . .

2. Periods of inundation and average maximum depth of inundation in southern and northern areas of Ellison Park wetland, Monroe County, N.Y., $1991-96$. . . . . . . . . . . . . . . . . . . . . . . . .

3. Explanatory variables used in regression models developed to compute constituent loads for Irondequoit Creek above Blossom Road (wetland inlet) and at Empire Boulevard (wetland outlet), Monroe County, N.Y., 1990-96 .

4. Regression statistics for models used to compute constituent loads for Irondequoit Creek above Blossom Road (wetland inlet) and at Empire Boulevard (wetland outlet), Monroe County, N.Y., 1990-96 . . . . . . . . . . . .

5. Statistics (p-values) related to tests of significant difference between monthly constituent loads computed for Irondequoit Creek above Blossom Road (wetland inlet) and at Empire Boulevard (wetland outlet), Monroe

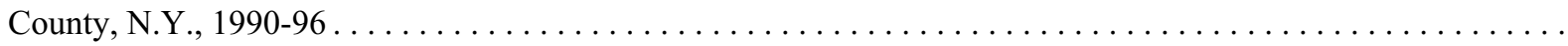

6. Spearman correlation coefficients between constituent loads and removal efficiencies and four variables, Ellison

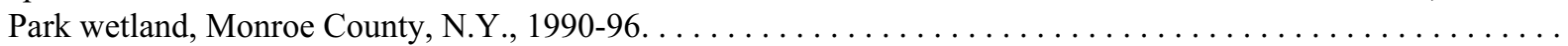

7. Concentrations and average annual input and output loads, and removal efficiency, for selected constituents, Ellison Park wetland, Monroe County, N.Y., 1990-96 . .

8. Selected statistics on trace-metal concentrations in Irondequoit Creek above Blossom Road (wetland inlet) and at Empire Boulevard (wetland outlet), Monroe County, N.Y., 1990-96 . . . . . . . . . . . . . . . . . . . .

9. Concentrations of selected chemicals in sediment of Ellison Park wetland, Monroe County, N.Y., October 1994. .

10. Characteristics of Typha glauca in Ellison Park wetland, Monroe County, N.Y., 1991 and 1996 . . . . . . . . . . .

11. Average dry-weight percentage or concentration of selected elements in above- and below-ground biomass of Typha glauca in Ellison Park wetland, Monroe County, N.Y., 1991 and 1996 . . . . . . . . . . . . . . . . . .

12. Average standing stocks of selected elements in above- and below-ground biomass of Typha glauca in Ellison

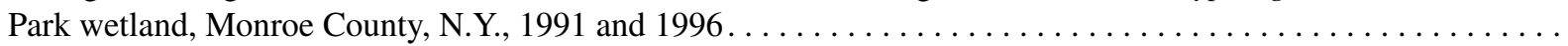

13. Estimated average annual loads of selected chemical constituents entering Irondequoit Bay, Monroe

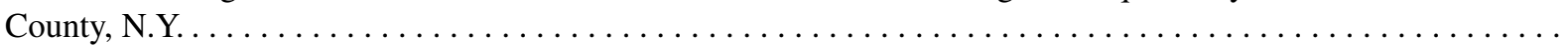




\section{APPENDIXES}

1. Selected chemical analyses of water samples from Irondequoit Creek above Blossom Road and at Empire Boulevard (Ellison Park wetland inflow and outflow sites), Monroe County, N.Y., 1990-96 . . . . . . . . . . . .

2. Monthly and annual constituent input and output loads and associated errors for Ellison Park wetland, Monroe

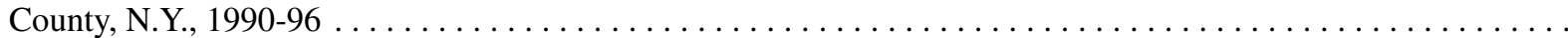

3. Monthly removal efficiencies for selected constituents as percentage of input load retained in Ellison Park

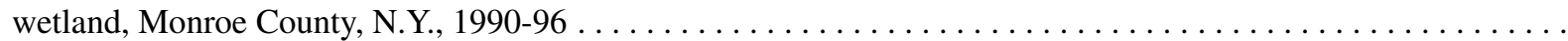

4. Chemical analyses of four sediment samples collected in the Ellison Park wetland, Monroe County, N.Y., October 1994 . 


\begin{tabular}{|c|c|c|}
\hline \multicolumn{3}{|c|}{ INCH-POUND TO INTERNATIONAL SYSTEM (SI) UNITS } \\
\hline Multiply & By & To obtain \\
\hline \multicolumn{3}{|c|}{ Length } \\
\hline inch (in.) & 2.54 & centimeter \\
\hline inch (in.) & 25.4 & millimeter \\
\hline foot $(\mathrm{ft})$ & 0.3048 & meter \\
\hline mile (mi) & 1.609 & kilometer \\
\hline \multicolumn{3}{|c|}{ Area } \\
\hline acre & 0.4047 & hectare \\
\hline square foot $\left(\mathrm{ft}^{2}\right)$ & 0.09290 & square meter \\
\hline square mile $\left(\mathrm{mi}^{2}\right)$ & 2.590 & square kilometer \\
\hline \multicolumn{3}{|c|}{ Volume } \\
\hline cubic foot $\left(\mathrm{ft}^{3}\right)$ & 0.02832 & cubic meter \\
\hline acre-foot (acre-ft) & 1,233 & cubic meter \\
\hline \multicolumn{3}{|c|}{ Flow rate } \\
\hline cubic foot per second $\left(\mathrm{ft}^{3} / \mathrm{s}\right)$ & 0.02832 & cubic meter per second \\
\hline \multicolumn{3}{|c|}{ Mass } \\
\hline ounce, avoirdupois (oz) & 28.35 & gram \\
\hline pound, avoirdupois (lb) & 0.4536 & kilogram \\
\hline ton, short $(2,000 \mathrm{lb})$ & 0.9072 & megagram \\
\hline \multicolumn{3}{|c|}{ INTERNATIONAL SYSTEM (SI) TO INCH-POUND UNITS } \\
\hline Multiply & By & To obtain \\
\hline \multicolumn{3}{|c|}{ Length } \\
\hline centimeter $(\mathrm{cm})$ & 0.3937 & inch \\
\hline millimeter $(\mathrm{mm})$ & 0.03937 & inch \\
\hline meter $(\mathrm{m})$ & 3.281 & foot \\
\hline kilometer $(\mathrm{km})$ & 0.6214 & mile \\
\hline \multicolumn{3}{|c|}{ Area } \\
\hline hectare (ha) & 2.471 & acre \\
\hline square meter $\left(\mathrm{m}^{2}\right)$ & 10.76 & square foot \\
\hline square kilometer $\left(\mathrm{km}^{2}\right)$ & 0.3861 & square mile \\
\hline \multicolumn{3}{|c|}{ Volume } \\
\hline cubic meter $\left(\mathrm{m}^{3}\right)$ & 35.31 & cubic foot \\
\hline cubic meter $\left(\mathrm{m}^{3}\right)$ & 0.0008107 & acre-foot \\
\hline \multicolumn{3}{|c|}{ Flow rate } \\
\hline cubic meter per second $\left(\mathrm{m}^{3} / \mathrm{s}\right)$ & 35.31 & cubic foot per second \\
\hline \multicolumn{3}{|c|}{ Mass } \\
\hline $\operatorname{gram}(\mathrm{g})$ & 0.03527 & ounce, avoirdupois \\
\hline kilogram (kg) & 2.205 & pound, avoirdupois \\
\hline gram per square meter $\left(\mathrm{g} / \mathrm{m}^{2}\right)$ & .0002049 & pound per square foot \\
\hline megagram (Mg) & 1.102 & ton, short $(2,000 \mathrm{lb})$ \\
\hline
\end{tabular}

Specific conductance is given in microsiemens per centimeter at 25 degrees Celsius $\left(\mu \mathrm{S} / \mathrm{cm}\right.$ at $\left.25{ }^{\circ} \mathrm{C}\right)$.

Temperature: degrees Celsius $\left({ }^{\circ} \mathrm{C}\right)=5 / 9$ (degrees Fahrenheit $\left({ }^{\circ} \mathrm{F}\right)$ minus 32$)$

Concentrations of chemical constituents in water are given either in:

milligrams per liter $(\mathrm{mg} / \mathrm{L}) \approx$ micrograms per gram $(\mathrm{mg} / \mathrm{g})=$ parts per million $(\mathrm{ppm})$; or micrograms per liter $(\mu \mathrm{g} / \mathrm{L}) \approx$ micrograms per kilogram $(\mu \mathrm{g} / \mathrm{kg})=$ parts per billion $(\mathrm{ppb})$

National Geodetic Vertical Datum of 1929 (NGVD) is a geodetic datum derived from a general adjustment of the first-order level nets of both the United States and Canada, formerly called Sea Level Datum of 1929. 


\title{
Effects of a Cattail Wetland on Water Quality of Irondequoit Creek near Rochester, New York
}

\author{
by William F. Coon, John M. Bernard ${ }^{1}$, and Franz K. Seischab ${ }^{2}$
}

\section{ABSTRACT}

A 6-year (1990-96) study of the Ellison Park wetland, a 423-acre, predominantly cattail (Typha glauca) marsh in Monroe County, N.Y., was conducted to document the effect that this wetland has on the water quality of Irondequoit Creek, which flows through it. Irondequoit Creek drains 151 square miles of mostly urban and suburban land and is the main tributary to Irondequoit Bay on Lake Ontario. The wetland was a sink for total phosphorus and total suspended solids ( 28 and 47 percent removal efficiencies, respectively, over the 6-year study period). Sedimentation and vegetative filtration appear to be the primary mechanisms for the decrease in loads of these constituents. Total nitrogen loads were decreased slightly by the wetland; removal efficiencies for ammonia-plusorganic nitrogen and nitrate-plus-nitrite were 6 and 3 percent, respectively. The proportions of total phosphorus and total nitrogen constituents were altered by the wetland. Orthophosphate and ammonia nitrogen were generated within the wetland and represented 12 percent of the totalphosphorus output load and 1.8 percent of totalnitrogen output load, respectively. Conservative chemicals, such as chloride and sulfate, were little affected by the wetland. Concentrations of zinc, lead, and cadmium showed statistically significant decreases, which are attributed to sedimentation

\footnotetext{
${ }^{1}$ Department of Biology, Ithaca College, Ithaca, N.Y.

${ }^{2}$ Department of Biology, Rochester Institute of Technology, Rochester, N.Y.
}

and filtration of sediment and organic matter to which these elements adsorb.

Sediment samples from open-water depositional areas in the wetland contained high concentrations of (1) trace metals, including barium, manganese, strontium, zinc (each of which exceeded 200 parts per million), as well as chromium, copper, lead, and vanadium, and (2) some polycyclic aromatic hydrocarbons. Persistent organochlorine pesticides, such as chlordane, dieldrin, DDT and its degradation products (DDD and DDE), and polychlorinated biphenyls (PCB's), also were detected, but concentrations of these compounds were within the ranges often found in depositional environments in highly urbanized areas.

Cattail shoots attained a maximum height of 350 centimeters, a density of more than 30 shoots per square meter, and total biomass of more than 5,600 grams per square meter (46 percent of which was in above-ground tissues during the growing season). Nitrogen and potassium were three times more abundant in above-ground tissues ( 2.4 and 1.5 percent by dry weight, respectively) than in below-ground tissues ( 0.8 and 0.5 percent, respectively).

Concentrations of phosphorus, molybdenum, and manganese in above-ground tissues were similar to those in below-ground tissues, but the concentrations of all other constituents were considerably higher in below-ground tissues. Concentrations of several elements exceeded those typically found in natural wetlands; these included manganese (417 ppm, parts per million) and sodium $(3,600 \mathrm{ppm})$ in above-ground tissues, and aluminum (1,540 ppm), iron (15,400 ppm), 
manganese (433 ppm), and sodium (10,000 ppm) in below-ground tissues.

Large quantities of nutrients are assimilated by wetland vegetation during the growing season, but neither tissue production nor microbial metabolic processes appeared to play a significant role in the observed patterns of surface-water chemical input-to-output relations on a seasonal basis. Presumably, internal cycling of nutrients sequestered in the sediments and detritus, combined with a summer increase in microbially mediated chemical transformations, obscured the effects of vegetative assimilation during the summer on surface-water chemical loads. Additionally, the natural confinement of most flows within the banks of Irondequoit Creek, which resulted in passage of stormwater through the wetland with little dispersion or detention in the cattail and backwater areas, diminished the capability of the wetland to improve water quality. Additional factors that probably affected the chemical-removal efficiency of the wetland included chemical inflow loading rates, storage and release mechanisms of the sediments (sedimentation, adsorption, filtration, precipitation, dissolution, and resuspension), and accretion and burial of organic matter.

Measurements of chlorophyll_a concentrations, and calculations of potential phosphorus concentrations, since the 1970's indicate an improvement in the trophic state of Irondequoit Bay. Estimated average annual loads (1990-96) of selected constituents entering Irondequoit Bay indicate that, since 1980, the loads of all major forms of nitrogen have decreased, chloride loads have increased, and sulfate loads have changed little. Inputs of total phosphorus and suspended solids to the wetland have increased since 1980, possibly as a result of increased erosion by stormflows from an increasingly developed watershed. The wetland decreases the loads of these constituents, but the trends of these loads entering Irondequoit Bay cannot be reliably defined because the removal efficiencies during the two earlier study periods (1980-81 and 1984-88) are unknown.

\section{INTRODUCTION}

Wetlands have been recognized as important ecosystems that provide unique habitats for fish, wildlife, and plants. They provide many other functions and values, including ground-water recharge and discharge, flood storage and desynchronization of flood waves, shoreline anchoring and dissipation of erosive forces, sediment trapping and removal of adsorbed chemicals (heavy metals and organic compounds), nutrient retention and removal, nutrient cycling, food-chain support (production, decomposition, consumption, and detrital export), recreation (swimming, boating, fishing, nature study), and scientific research (Adamus and Stockwell, 1983; and Mitsch and Gosselink, 1986). Among these functions is the potential to improve water quality by facilitating the retention or removal of sediment and nutrients carried by urban stormwater. This function can be achieved through various processes, including sedimentation (settling), adsorption, chemical precipitation, filtration, biochemical interactions and microbially mediated transformations, nutrient assimilation, volatilization and aerosol formation, infiltration (Strecker and others, 1992), ion exchange, biodegradation (U.S. Environmental Protection Agency, 1993), and long-term storage of chemicals through accretion and burial (Mitsch and Gosselink, 1986). These processes can cause a wetland to act as either a temporary or permanent sink for certain constituents. Other processes, such as leaching, decomposition, dissolution, diffusion from sediments, and, again, microbially mediated transformations, can cause a wetland to act as a source for certain constituents by generating these constituents and exporting them in quantities larger than those that entered the wetland (Kadlec and Knight, 1996; Strecker and others, 1992; Mitsch and Gosselink, 1986; U.S. Environmental Protection Agency, 1993).

Mitsch and Gosselink (1986) note that the effects of nutrient uptake by macrophytes, algae, bacteria, and fungi on water quality in the wetland can be similar to those of secondary and advanced treatment of wastewater. Johnston (1991) points out that physical and microbial processes in a wetland generally have a greater effect than vegetative uptake in the retention of sediment and nutrients. Hickok and others (1977) conclude that, barring flooded or cold soil conditions, which inhibit microbial processes, microbial activity is the principal mechanism for removing phosphorus from the soil-water solution. 
Natural and constructed wetlands have been studied since the 1960's and are receiving widespread use as cost-effective and environmentally beneficial means of mitigating the deleterious effects of storm runoff and wastewater on receiving surface-water bodies and ground-water systems (Kadlec and Knight, 1996; Strecker and others, 1992; U.S. Environmental Protection Agency, 1993; Livingston, 1989; Gadbois, 1989). One factor that largely determines a wetland's removal efficiency for the primary nutrients (phosphorus and nitrogen) is macrophyte density that is, the amount of surface area to which bacteria, fungi, and epiphytic algae can adhere (Kadlec and Knight, 1996). These microbes facilitate the assimilation and transformation of nutrients and form a biofilm on substrate surfaces.

The processes of water-quality improvement in a wetland are interrelated, and the relative importance of any one mechanism can vary from wetland to wetland. The broad range in the effectiveness of wetlands in treating stormwater results from (1) the diversity among wetlands in terms of vegetation, depth and duration of inundation, climatic factors, soils, and hydraulic characteristics, and (2) differences in water sources (surface water, ground water, or atmospheric deposition) and in water chemistry. The balance between chemical uptake and retention, and chemical release (through leaching, decomposition, and plantfacilitated transfer from the sediments to overlying waters) and export (through surface flow and atmospheric exchange) determines a wetland's net effect on water quality. Chemical retention or export can be affected by many factors, including the wetland's size and water-storage capacity; the rate and velocity of flow; the detention time of stormwater; the flow pattern and degree of dispersal or mixing (circulation); the presence or absence of pools for sediment accumulation; the frequency, duration, and depth of inundation; the types and density of vegetation; the water $\mathrm{pH}$, temperature, dissolvedoxygen concentration, and turbidity or amount of light penetration; the season; the types of maintenance practices used (removal of sediment or vegetation); and the chemical-exchange rates between water and sediment (Livingston, 1989; Strecker and others, 1992; Kadlec and Knight, 1996; Adamus and Stockwell, 1983).

The hydrologic characteristics of a wetland play a major role in its structure and water-qualityimprovement function in that they (1) determine or modify the composition, diversity, and distribution of wetland flora; (2) affect the level of productivity through volume and circulation of flow and through duration and frequency of inundation; and (3) affect (a) rates of sedimentation, resuspension, and erosion; (b) rates of organic accumulation and export; and (c) the input, output, transformation, and cycling of nutrients and other constituents (Mitsch and Gosselink, 1986).

\section{Irondequoit Creek Basin}

The Irondequoit Creek basin, east and southeast of Rochester, in Monroe and Ontario Counties, has been the subject of numerous water-quality studies in response to public concern over the sedimentation and eutrophication of Irondequoit Bay on Lake Ontario (fig. 1). Irondequoit Creek, the bay's main tributary, is the source of (1) nutrients that, in the past, supported summertime algal blooms in the bay (Pixley, 1982); (2) dissolved chloride, which can alter the bay's chemical and thermal stratification and interfere with seasonal mixing of the bay's waters (Diment and others, 1974; Bubeck and Burton, 1989); and (3) sediment to which heavy metals and organic compounds can adhere (Schroeder, 1985). Until the spring of 1977, effluent from 14 wastewater-treatment facilities within the basin and combined-sewer overflows from the city of Rochester were discharged into the creek (M. Schifano, Monroe County Pure Waters, oral commun., 1999). At present, these wastewaters are treated at a central location at the north end of Rochester and are discharged into Lake Ontario. These diversions of wastewater out of the basin have improved the water quality of Irondequoit Bay, but further improvement has been slowed by the continued input of contaminants from nonpoint sources in the basin-primarily nutrients, metals, and organic compounds washed from impervious surfaces by rain and snowmelt (R. Burton, Monroe County Environmental Health Laboratory, written comm., 1996).

\section{Previous Studies}

The hydrologic characteristics of the Irondequoit Creek basin were studied during 1979-81 as part of the Nationwide Urban Runoff Program (NURP) (O'Brien and Gere, 1983; Zarriello and others, 1985; Kappel and others, 1986). One goal of that study was to assess the effect of storm runoff and 
its associated nutrients and contaminants on the quality of water in Irondequoit Bay. Kappel and others (1986) estimated annual loads (1980-81) of selected constituents that entered the bay: 214 tons of ammonia-plus-organic nitrogen, 20.2 tons of total phosphorus, and 19,100 tons of total suspended solids. O'Brien and Gere (1983, p. iv) used a steady-state model and estimated that 15.7 tons of phosphorus were entering Irondequoit Bay annually (1980-81) from external sources and that, from an assumption of a zero net phosphorus release from the bottom sediments of the bay, the external loading would need to be decreased to about 5.6 tons annually to maintain the bay in a trophic state appropriate for recreational usage. They also indicated that 50 to 75 percent of the annual phosphorus loads entered the bay during a 3-month period that included the major seasonal snowmelt and spring runoff. A unique component of the Irondequoit Creek NURP study (Kappel and others, 1986) was the inclusion of an in-stream natural wetland (Ellison Park) in the study's monitoring program (fig. 2). Several NURP projects considered wetlands to be promising mechanisms for treatment of urban runoff, but these projects did not include development of performance or design criteria (U.S. Environmental Protection Agency, 1983).

\section{Ellison Park Wetland}

The Irondequoit Creek NURP study identified the large, predominantly cattailcovered Ellison Park wetland near the mouth of Irondequoit Creek, just south of Irondequoit Bay, as the most cost-effective means of decreasing nutrient loads entering the bay (O'Brien and Gere, 1983). Kappel and others (1986) estimated that the wetland provided a 10-percent decrease in phosphorus loads and theorized that an additional 15 percent decrease (primarily through deposition and mineralization of particulate phosphorus associated with the silt-clay sediment fraction) could be achieved if flows through the wetland were regulated and waterdispersal and detention time increased. Similarly, O'Brien and Gere (1983) estimated an annual phosphorus removal of 24 percent could be attained through operation of a flow-control structure installed

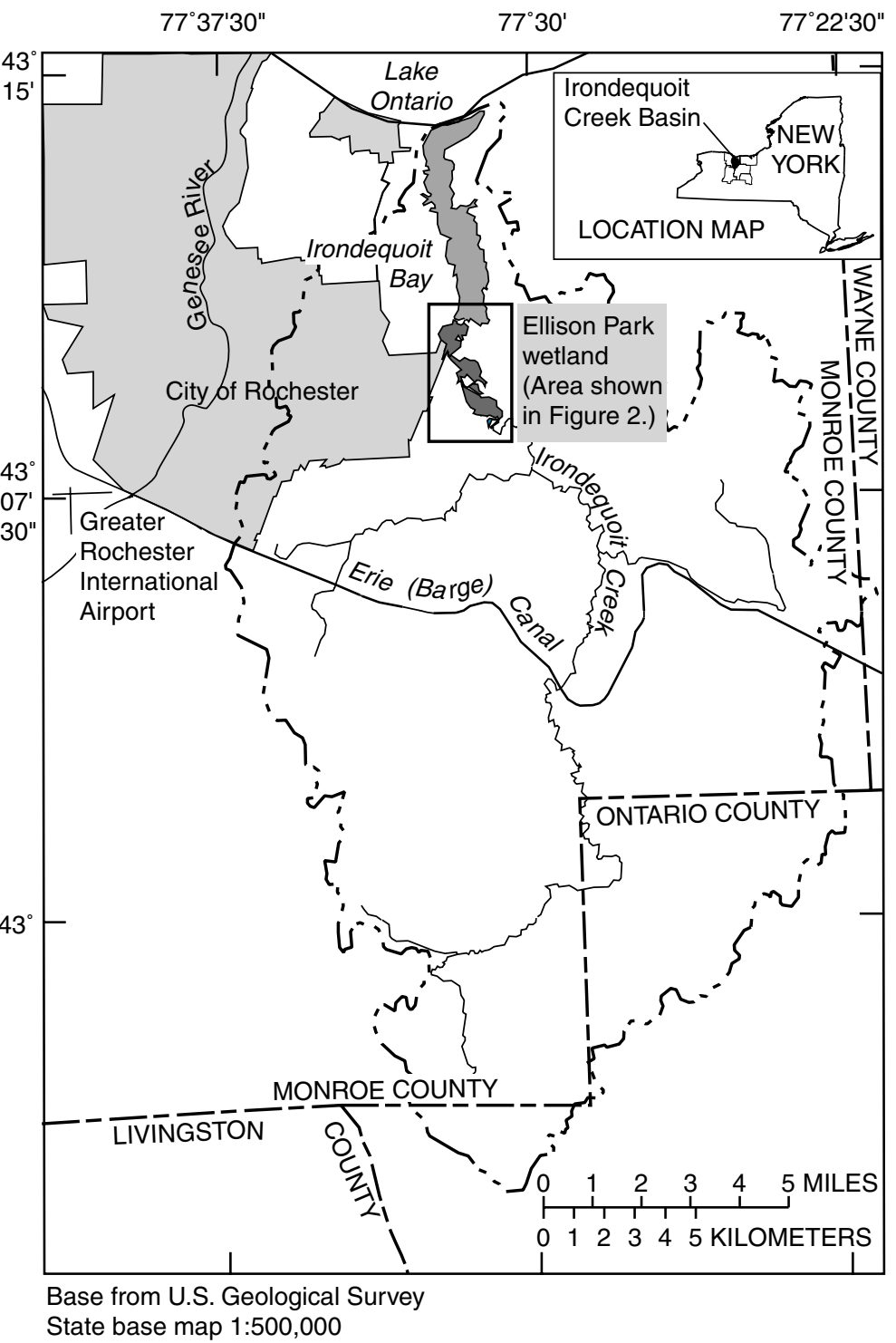

Figure 1. Location of study area and major geographic features of Irondequoit Creek basin, Monroe County, N.Y.

at a natural constriction in the wetland midway between Browncroft and Empire Boulevards (fig. 2).

In 1990, the U.S. Geological Survey (USGS), in cooperation with the Monroe County Department of Health, began a 6-year study of the wetland to evaluate its potential for water-quality improvement.

Streamflow and water chemistry of Irondequoit Creek at the upstream and downstream ends of the wetland were monitored. Concurrent biological studies of the fish, bird, and benthic-macroinvertebrate communities in the wetland were conducted (Miller and Ringler, 1992). Wetland flora and vegetation studies were conducted in 1991 and 1996 (Bernard and Seischab, 
1991 and 1997) between Browncroft and Empire

Boulevards to (1) identify individual species, (2) map plant communities, (3) measure cattail density (shoots per square meter) and above- and below-ground biomass, and (4) provide chemical analyses of aboveand below-ground cattail tissues.

A description of the hydrologic,

sedimentological, and biological characteristics of the wetland is given by Coon (1997), who noted that (1) water levels in the wetland are controlled by the surface elevation of Lake Ontario; (2) bankfull and lower flows of Irondequoit Creek do not disperse through the wetland, but are mostly confined within the banks of the main channel and usually pass through the wetland in less than 3.5 hours; dispersal of stormflows occurs only when flows exceed the capacity of the channel (overbank flows), which on average occurs twice a year; (3) dispersed water moves into the cattail-covered backwater areas of the wetland, where it can be detained for 3 to 15 hours or more (the maximum detention time has not been determined); (4) dispersal of flows also occurs during backwater conditions that result from high water levels on Lake Ontario, usually from April to July; (5) the channel sediments in the wetland range from sand, which is found in the main channel of Irondequoit Creek, to silt and clay with a high concentration of organic matter (about 4 percent total organic carbon by weight), in the backwater areas; (6) sedimentation in the wetland is sporadic, but an annual sedimentation rate from 0.006 to $0.016 \mathrm{ft}$ has been estimated. Data on the biological structure of the wetland are summarized in Coon (1997) and include (1) the identification and distribution of fish species during 1991-92 (Miller and Ringler, 1992); (2) results of the bird surveys conducted during 1980-85 (Andrle and Carroll, 1988) and 1991-92 (Miller and Ringler, 1992); (3) a cursory description of the macroinvertebrate community based on the analyses of the stomach contents of fishes (Miller and Ringler, 1992); and (4) a general description of the wetland flora (Bernard and Seischab, 1991).

\section{Purpose and Scope}

This report (1) presents Ellison Park wetland's monthly and annual inflow and outflow loads of total nitrogen, ammonia-plus-organic nitrogen, ammonia, organic nitrogen, nitrate-plus-nitrite nitrogen, total phosphorus, orthophosphate, total and volatile

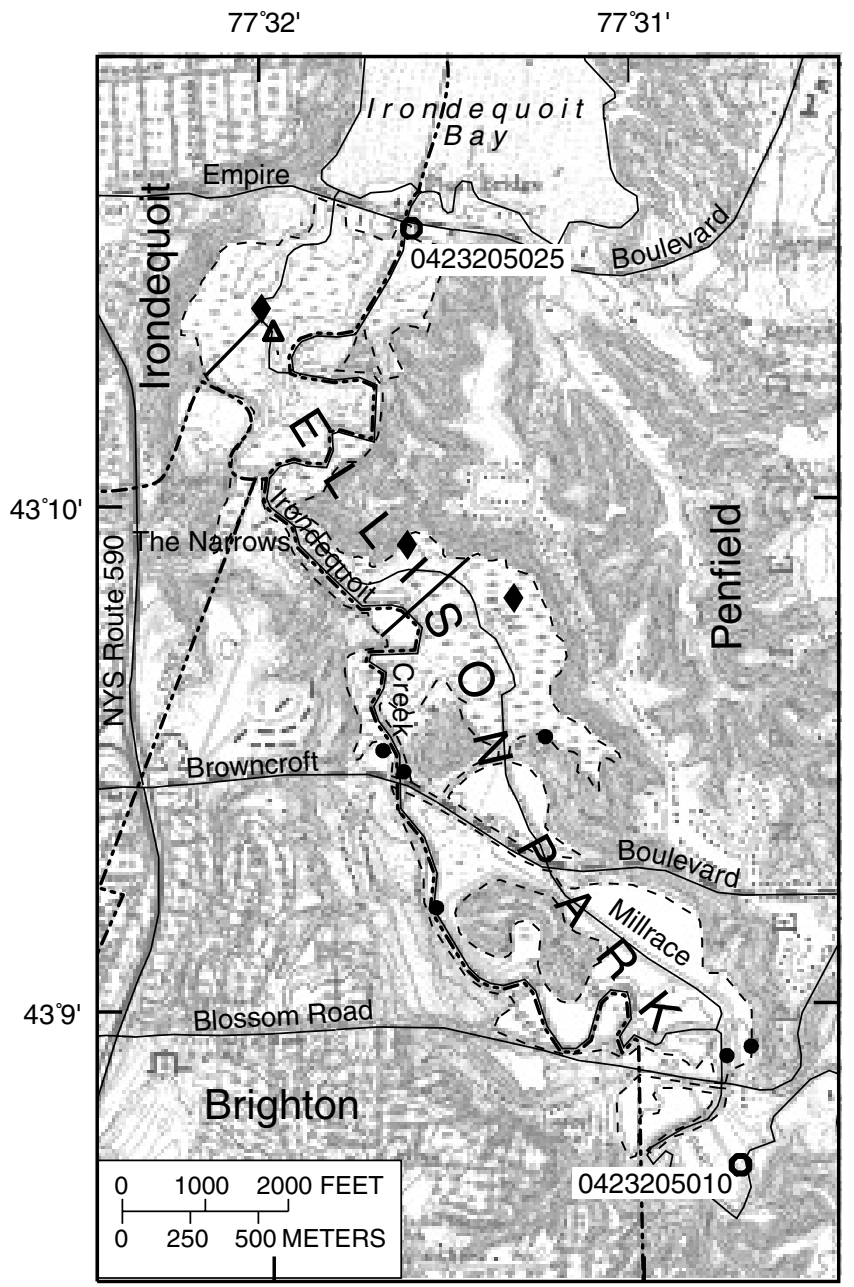

Base from scanned U.S. Geological Survey Rochester East, NY 1:24,000, 1978

\section{EXPLANATION}

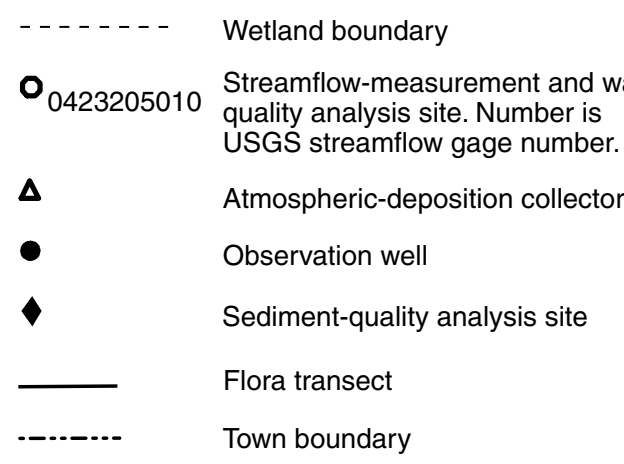

Figure 2. Locations of data-collection sites and Ellison Park wetland within the Irondequoit Creek basin, Monroe County, N.Y. (Location is shown in fig. 1.)

suspended solids, chloride, and sulfate, during the 1990-96 water years (a water year is the period from October of one year to September of the following year); (2) gives the wetland's computed monthly and 
annual removal efficiencies for the above constituents; (3) assesses the effect of the wetland on surface-water temperature; (4) describes the physical and chemical characteristics of the vegetation and recently deposited sediment in the wetland; (5) discusses the role of the wetland sediment and vegetation, primarily cattail (Typha glauca), in the retention or export of nutrients; and (6) assesses the current ecological status of Irondequoit Bay in terms of trophic state and trends in estimated constituent loads entering the bay. Detailed chemical analyses of water and sediment samples are given in the appendixes.

\section{Study Area}

The Irondequoit Bay watershed covers an area of $169 \mathrm{mi}^{2}$ (fig. 1), of which $151 \mathrm{mi}^{2}$ is drained by Irondequoit Creek, which flows into the south end of Irondequoit Bay. About 54 percent of the watershed is urban or suburban, and about 34 percent is agricultural (Christopher Sciacca, Monroe County Planning Board, written commun., 1998). The upstream (southern) part of the basin is dominated by forest and agricultural areas but is becoming increasingly developed.

\section{Precipitation}

Average annual precipitation in the Rochester area is 32.4 in. (168 years of record), including that from an average snowfall of about 90 in. (55 years of record), as recorded by the National Weather Service station at the Greater Rochester International Airport (National Climatic Data Center, 1996). Monthly precipitation quantities during the 1990-96 study period (table 1) are plotted with 30-year (1961-90) mean monthly precipitation values in figure $3 \mathrm{~A}$. Monthly precipitation greatly exceeded the long-term average during July 1992, October 1995, and June 1996, and was substantially below average during February and June 1991; May, July and August 1993; July and October 1994; and February through June 1995.

\section{Location}

The wetland (referred to in this report as the Ellison Park wetland) lies at the mouth of Irondequoit Creek along the township boundaries of Irondequoit, Brighton, and Penfield in Monroe County (fig. 2). The wetland, which forms a transition zone between the riparian environment of the creek and the lacustrine environment of Irondequoit Bay, encompasses about 423 acres at and below an elevation of $250 \mathrm{ft}$ (DeGaspari and Bannister, 1983) and covers less than 0.5 percent of the creek's total drainage area. Bounded by steep valley sides on the east and west, it covers the entire valley floor from Blossom Road to Empire Boulevard. Between Browncroft and Empire Boulevards, the wetland is dominated by cattails and is divided into southern and northern segments (263 acres and 160 acres, respectively, DeGaspari and Bannister, 1983) by a natural constriction that is locally referred to as the Narrows (fig. 2). The width of the wetland ranges from $200 \mathrm{ft}$ at the Narrows to $2,500 \mathrm{ft}$ in the southern and northern parts.

Table 1. Monthly and annual total precipitation recorded at Greater Rochester International Airport, Rochester, N.Y., 1990-96, with normal 30-year (1961-90) means

[Data from National Climatic Data Center (1996). Values are in inches. Location is shown in fig. 1]

\begin{tabular}{|c|c|c|c|c|c|c|c|c|c|c|c|c|c|}
\hline \multirow[b]{2}{*}{ Year } & \multicolumn{12}{|c|}{ Monthly } & \multirow[b]{2}{*}{ Annual } \\
\hline & Jan & Feb & Mar & Apr & May & Jun & Jul & Aug & Sep & Oct & Nov & Dec & \\
\hline 1990 & 1.61 & 3.93 & 1.56 & 3.58 & 5.76 & 2.88 & 3.05 & 3.59 & 3.36 & 4.37 & 2.27 & 4.18 & 40.14 \\
\hline 1991 & 1.69 & 1.16 & 4.70 & 4.07 & 2.43 & 1.19 & 2.37 & 1.80 & 2.86 & 1.65 & 2.39 & 2.92 & 29.23 \\
\hline 1992 & 1.46 & 1.87 & 3.53 & 3.43 & 2.83 & 1.98 & 6.03 & 4.45 & 3.02 & 1.78 & 2.90 & 2.98 & 36.26 \\
\hline 1993 & 2.32 & 1.52 & 2.44 & 3.07 & 1.24 & 2.76 & 1.67 & 1.67 & 4.37 & 3.21 & 3.27 & 1.60 & 29.14 \\
\hline 1994 & 2.68 & 1.63 & 1.70 & 4.08 & 2.56 & 2.43 & 0.61 & 4.27 & 2.68 & 1.34 & 3.24 & 2.32 & 29.54 \\
\hline 1995 & 2.46 & 1.58 & 1.15 & 1.18 & 1.75 & 2.07 & 3.85 & 3.05 & 1.50 & 5.70 & 4.21 & 1.50 & 30.00 \\
\hline 1996 & 3.18 & 1.72 & 2.07 & 4.84 & 3.51 & 6.65 & 2.18 & 3.33 & 5.09 & 5.40 & 4.12 & 2.97 & 45.06 \\
\hline $\begin{array}{l}\text { Normal mean, } \\
1961-90\end{array}$ & 2.08 & 2.10 & 2.28 & 2.61 & 2.72 & 3.00 & 2.71 & 3.40 & 2.97 & 2.44 & 2.92 & 2.73 & 31.96 \\
\hline
\end{tabular}



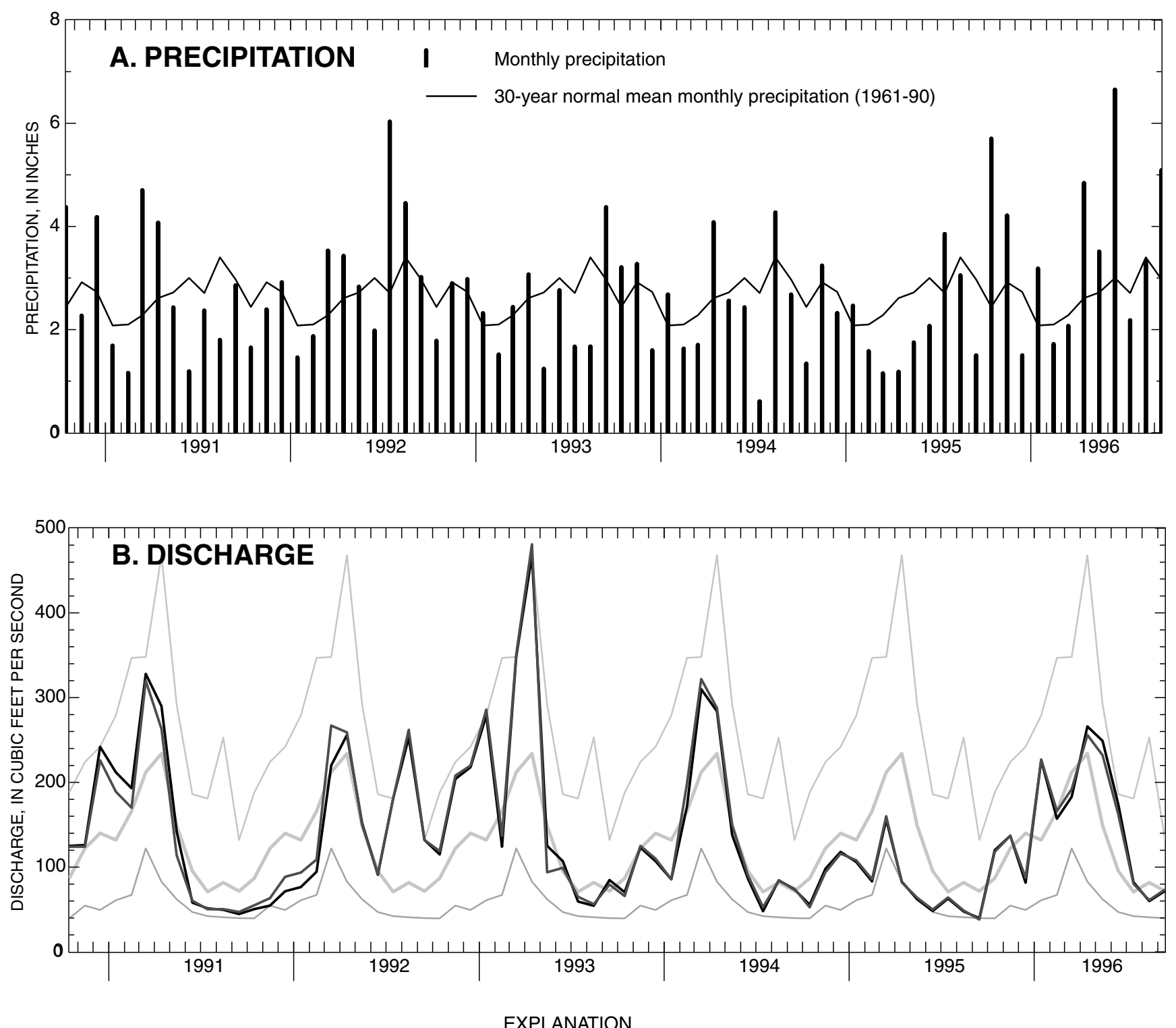

Monthly mean discharge for this study (1991-96)

Monthly discharge at Blossom Road for period of record (1981-96)
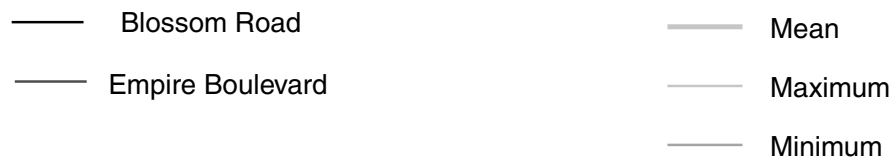

Figure 3. A. Monthly precipitation, 1990-96, and normal (1961-90) mean monthly precipitation, recorded at the Greater Rochester International Airport, Rochester, N.Y. B. Monthly mean discharges at Irondequoit Creek above Blossom Road and at Empire Boulevard, 1990-96, with monthly maximum, mean, and minimum discharges for the period of record at Blossom Road, 1981-96, Monroe County, N.Y. (Locations are shown in figs. 1 and 2.)

\section{Wetland Characteristics}

The Ellison Park wetland is classified as a palustrine persistent emergent wetland by the U.S. Fish and Wildlife Service (Cowardin and others, 1979); that is, a nontidal marsh characterized by erect, rooted, herbaceous hydrophytes that may be temporarily or permanently flooded at the base and normally remain standing at least until the beginning of the next growing season. Cattails, primarily Typha glauca, cover about 265 acres, or 63 percent of the wetland surface area, which is most of the unponded area of the wetland between Browncroft and Empire 
Boulevards. (Acreages were digitized from a USGS 7.5-minute topographic map, Rochester East, N.Y. quadrangle.) Plant diversity is greatest on the banks of the main channel of Irondequoit Creek and along the wetland margins, where soil wetness varies with slight elevation differences. Open-water areas, including channels, cover about 99 acres, or 23 percent of the wetland. A hardwood-forested wetland between Browncroft Boulevard and Blossom Road covers about 25 acres, or 6 percent of the wetland, and maintained grass areas of the county park below the wetland-demarcation elevation of $250 \mathrm{ft}$ (National Geodetic Vertical Datum, NGVD) cover the rest of the wetland (about 34 acres, or 8 percent of the wetland).

The Ellison Park wetland contains hydric soil, defined by the U.S. Soil Conservation Service (1985) as soil that in its undrained condition is saturated, flooded, or ponded long enough during the growing season to develop anaerobic conditions that favor the growth and regeneration of hydrophytic vegetation. It is a mineral soil, formed through the deposition of alluvium (flood-plain deposits) from the Irondequoit Creek basin. The upper layer consists of a dense accumulation of partly decomposed organic material.

\section{Hydrology}

Wetland conditions in Ellison Park are wholly or partly dependent on the surface elevation of Lake Ontario, which is maintained within a narrow range through regulation of control structures on the St. Lawrence Seaway. Data collected at a streamflowmonitoring station at Empire Boulevard indicate that water-surface elevations at the mouth of the wetland fluctuated only $4.1 \mathrm{ft}$ during 1990-96 (fig. 4). Lake Ontario water levels usually rise during the springrunoff period and are maintained through the summer for navigational and recreational purposes and for hydroelectric-power generation on the St. Lawrence River near Massena, N.Y. Water levels are lowered in December and January to increase the storage capacity for spring runoff (Paul Yu, U.S. Army Corps of Engineers, oral commun., 1997). When the watersurface elevation recorded at the streamflowmonitoring site at Empire Boulevard is at or above $246.9 \mathrm{ft}$, most of the cattail-covered area in the southern and northern wetland sections is inundated. At a slightly lower elevation, $246.5 \mathrm{ft}$, the water levels in the southern wetland area drop below land surface, and only the northernmost part of the northern wetland area remains inundated. Water levels range from $2 \mathrm{ft}$ or more above land surface to $1.5 \mathrm{ft}$ below. Flat vegetated areas of the wetland can be briefly inundated by runoff from large storms and are seasonally inundated for periods of 4 to 7 months. The duration of seasonal inundation (hydroperiod) varies from year to year and from south to north; in some years, the water level rises only enough to inundate the southern wetland area for several days, but in other years, high water levels can persist from January through August (fig. 4 and table 2). The 6 years of water-level data from this study (1990-96) show that the hydroperiod averaged 136 days per year in the southern wetland area and 189 days per year in the northern wetland area. The maximum depth of inundation during these periods ranged from 0.1 to $2.4 \mathrm{ft}$ (average $1.1 \mathrm{ft}$ ) in the southern wetland area, and from 0.5 to $2.8 \mathrm{ft}$ (average $1.5 \mathrm{ft}$ ) in the northern area.

Two channels convey water through the wetland-the main channel of Irondequoit Creek, which carries most of the flow, and a smaller channel, locally referred to as the Millrace, which formerly was the outlet raceway for a flour mill on the east bank of the creek just upstream from Blossom Road but currently is a diversion from the main channel downstream from Blossom Road to the eastern part of the southern wetland area north of Browncroft Boulevard. In the vicinity of Blossom Road, the main channel is about $70 \mathrm{ft}$ wide and from 10 to $12 \mathrm{ft}$ deep at bankfull stage, whereas the Millrace is 20 to $25 \mathrm{ft}$ wide and 5 to $6 \mathrm{ft}$ deep. Between Browncroft Boulevard and the Narrows, the main channel dimensions decrease to a bankfull width of 50 to $60 \mathrm{ft}$ and depth of 5 to $8 \mathrm{ft}$. The extension of the Millrace channel into the southern wetland area widens to about $50 \mathrm{ft}$ but is only about $3 \mathrm{ft}$ deep. North of the Narrows, the depth of Irondequoit Creek generally continues to decrease to 3 or $4 \mathrm{ft}$.

Low flows usually occur during late summer; whereas peak flows result from snowmelt and rain during late winter and spring, and from summer thunderstorms. Daily mean flow in the creek, based on 16 years of record at the inflow-monitoring site (Blossom Road), exceeded $45 \mathrm{ft}^{3} / \mathrm{s} 90$ percent of the time, $87 \mathrm{ft}^{3} / \mathrm{s} 50$ percent of the time, and $251 \mathrm{ft}^{3} / \mathrm{s} 10$ percent of the time (Hornlein and others, 1997). Annual peak discharges ranged from $658 \mathrm{ft}^{3} / \mathrm{s}$ (November 2, 1994) to $1,710 \mathrm{ft}^{3} / \mathrm{s}$ (April 2, 1993) and usually exceeded $1,000 \mathrm{ft}^{3} / \mathrm{s}$. Overbank flows occur twice a year on average. Overbank flows causing inundation of the Ellison Park wetland occurred 3 to 4 


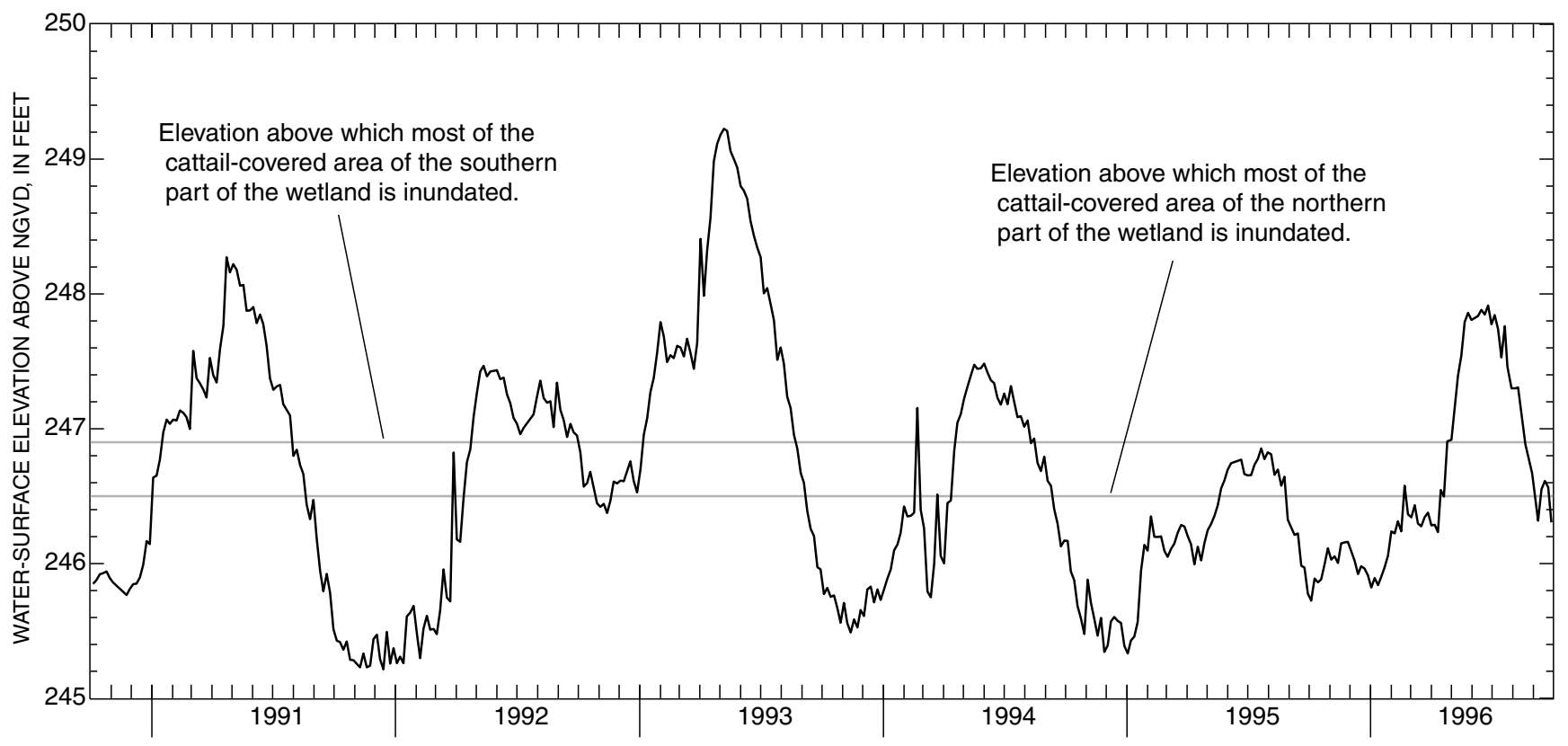

Figure 4. Daily mean water-surface elevation of Ellison Park wetland as measured at Empire Boulevard (wetland outlet), Monroe County, N.Y., 1990-96. (Location is shown in fig. 2.)

times yearly in 1990-92 and 1994, and once in 1993, which was the 16-year period-of-record peak flow; then did not occur at all in 1995. Monthly mean discharges of Irondequoit Creek above Blossom Road and at Empire Boulevard during the study period (fig. 3B) were below average for two extended periods-June 1991 through February 1992 and October 1994 through September 1995. The period-ofrecord peak discharge occurred during a period of above-average flow, March to April 1993. Monthly discharges also were above average from December 1990 through April 1991, July 1992 through January 1993, and March through April 1994.

The slope of the main channel decreases from about 0.003 upstream from the Blossom Road streamflow-monitoring site (measured from USGS 7.5minute topographic maps, Rochester East and Fairport, N.Y., quadrangles) to 0.0006 within the wetland from Blossom Road to Empire Boulevard (from survey data). This decrease in channel gradient, in conjunction with the wide wetland flood plain, promotes the sedimentation and filtering functions of the wetland and the attenuation of peak flows. Time-of-travel and flow-dispersion studies conducted in the wetland during 1991 (Coon, 1997) indicate the following:
(1) Medium-to-high flows (600 to $800 \mathrm{ft}^{3} / \mathrm{s}$ ) in the main channel are contained by banks that are higher than the cattail-covered areas beyond and move through the wetland with little dispersal into the cattail areas. The high banks are a result of preferential sediment deposition at the point where overbank flow

Table 2. Periods of inundation and average maximum depth of inundation in southern and northern areas of Ellison Park wetland, Monroe County, N.Y., 1991-96

[ft, feet. Locations are shown in fig. 2.]

\begin{tabular}{|c|c|c|c|c|}
\hline \multirow[b]{2}{*}{$\begin{array}{l}\text { Water } \\
\text { Year }^{1}\end{array}$} & \multicolumn{2}{|c|}{ Southern wetland area } & \multicolumn{2}{|c|}{ Northern wetland area } \\
\hline & $\begin{array}{l}\text { Period of } \\
\text { inundation } \\
\text { (days) }\end{array}$ & $\begin{array}{l}\text { Average } \\
\text { maximum } \\
\text { depth }(\mathrm{ft})\end{array}$ & $\begin{array}{l}\text { Period of } \\
\text { inundation } \\
\text { (days) }\end{array}$ & $\begin{array}{l}\text { Average } \\
\text { maximum } \\
\text { depth (ft) }\end{array}$ \\
\hline 1991 & 194 & 1.5 & 234 & 1.9 \\
\hline 1992 & 155 & 0.8 & 194 & 1.2 \\
\hline 1993 & 230 & 2.4 & 289 & 2.8 \\
\hline 1994 & 113 & 0.7 & 157 & 1.1 \\
\hline 1995 & 1 & 0.1 & 100 & 0.5 \\
\hline 1996 & 121 & 1.1 & 159 & 1.5 \\
\hline Mean & 136 & 1.1 & 189 & 1.5 \\
\hline
\end{tabular}

${ }^{1}$ Water year is the period from October of one year to September of the following year. 
velocities decrease and sediment is trapped by the dense vegetation along the bank tops.

(2) Overbank flows (greater than about $900 \mathrm{ft}^{3} / \mathrm{s}$ ) disperse through the cattail-covered areas.

(3) Water that leaves the main channel and flows through the Millrace into the backwater area of the southern part of the wetland becomes detained in that area for 3 to 15 hours or more; the maximum detention time has not been determined. The channel in this part of the wetland is shallower than the main channel and does not have well-defined banks; therefore, high flows are not confined to the channel and easily move into and through the adjacent cattail areas.

(4) Dispersal and detention of flows in both channels is facilitated by backwater from high water levels in Irondequoit Bay and Lake Ontario.

Increasing the detention time and the dispersal of stormflows, or maximizing the conditions that facilitate these results, presumably could result in water-quality improvement. Therefore, modifications were made to increase flow into the Millrace and into the eastern part of the southern wetland area, where detention and dispersal occur naturally. Discharge measurements made during 1991 indicated that the Millrace could convey as much as a quarter of the total flow during low-flow periods but carried a decreasing proportion of the flow as total flow in the creek increased (Coon, 1997). The diversion from the main channel to the Millrace downstream from Blossom Road was modified during the summer of 1994 by lowering and paving the top of the bank above the two diversion culverts (48-in.- and 36-in.-diameter pipes); thereby increasing flows in the Millrace for nearbankfull discharges.

Ground-water movement in the unconfined aquifer of the lower Irondequoit Creek basin moves from the valley walls toward Irondequoit Creek and underflow moves northward (downgradient) toward Irondequoit Bay and Lake Ontario (Yager and others, 1985). High water levels in the creek might cause short-term reversal of groundwater flow by recharging the streambank and flood-plain deposits, but generally the Ellison Park wetland is a ground-water discharge point (Kappel and Young, 1989).

\section{Acknowledgments}

Thanks are extended to the employees of Monroe County Environmental Health Laboratory (MCEHL) who assisted in the maintenance and operation of the streamflow- and water-qualitymonitoring sites and analyzed water samples. Richard Burton, laboratory administrator, provided guidance and suggestions throughout the data-collection period.

\section{METHODS}

The study included (1) collection and chemical analyses of surface-water, sediment, and cattail-tissue samples, (2) a program to assess the accuracy and validity of streamflow and water-quality data provided by the cooperating agency (Monroe County Environmental Health Laboratory), and (3) use of a USGS chemical-load estimation program (Cohn and others, 1989) to compute surface-water constituent loads in the wetland inflow and outflow. Each of these is described below.

\section{Data Collection}

The following paragraphs describe (1) field methods for the measurement of surface-water stage, velocity, and temperature, the collection of water and sediment samples, and the survey of the wetland flora and collection of cattail-tissue samples, and (2) laboratory methods used for chemical analyses of water, sediment, and cattail-tissue samples.

\section{Surface Water}

Stream discharge and water temperature were measured, and water samples collected, at the inlet (Blossom Road) and outlet (Empire Boulevard) of the Ellison Park wetland. Each monitoring station included an electronic data logger, water-stage and temperature sensors, and an automatic water sampler. The outlet station also had a water-velocity sensor. Sensors made measurements every 15 minutes, and the measured values were stored in the data loggers.

\section{Stream Discharge}

The upstream monitoring site was $4,000 \mathrm{ft}$ (channel distance) above Blossom Road (fig. 2). Discharge was computed from a stage-to-discharge relation by standard USGS procedures for gaging streamflow (Carter and Davidian, 1968; Rantz and others, 1982), measuring stage and discharge (Buchanan and Somers, 1968 and 1969, respectively), and analyzing stage-to-discharge relations (Kennedy, 
1984). Periodic field measurements of discharge were made to identify any deviations from the established stage-to-discharge relation. The downstream site (fig. 2) was on the bank of the short channel that connects the wetland with Irondequoit Bay. Computation of discharge for this site was complicated by backwater conditions caused by fluctuating water levels in Irondequoit Bay and Lake Ontario. Therefore, water velocity was measured with an acoustic velocity meter (AVM), and the recorded velocity was correlated with the mean velocity in the channel as calculated from discharge measurements made from the Empire Boulevard bridge. Discharge was computed from this relation and from the relation between stage and flow area. Standard USGS procedures for gaging streamflow with an AVM and analyzing stage-and-velocity-to-discharge relations (Laenen, 1985) were followed.

\section{Temperature}

Water temperatures were measured at each site intermittently during 1990-94 and continuously (every 15 minutes) from December 1994 through September 1996. The continuous measurements were made by temperature probes connected to the data loggers. Temperatures were measured manually during site inspections to verify the recorded temperatures and to permit correction, if necessary.

\section{Water Quality}

Automated samplers, which extracted water samples from the channel (near the centroid of flow) hourly and stored them in refrigerated bottles, were maintained by the Monroe County Environmental Health Laboratory (MCEHL). Samples were composited on the basis of discharge. If base-flow conditions prevailed during the entire sampling cycle (3 to 4 days), all samples were composited, and a single analysis was performed. During storms, samples were composited to represent conditions during the rising and falling phases of the storm hydrograph, and one or two near-peak samples were analyzed separately. Laboratory analyses were done by MCEHL, which participated in the USGS qualityassurance program for cooperating analytical laboratories. Analytical procedures are described in American Public Health Association and others (1995). Samples were analyzed for phosphorus (total and orthophosphate), nitrogen (total, ammonia-plusorganic, nitrate-plus-nitrite, and ammonia), chloride, sulfate, and suspended solids (total and volatile). Samples collected during stormflows, and periodically during low-flow periods, were analyzed additionally for total organic carbon, biochemical and chemical oxygen demand, alkalinity, specific conductance, and trace metals (zinc, lead, copper, and cadmium). (See Appendix 1.)

\section{Sediment Quality}

The chemical quality of sediment in the Ellison Park wetland was assessed through analyses of three fine-grained samples (plus one duplicate sample) collected in October 1994 from two sites in the backwater areas of the southern part of the wetland and one site in the northern part (fig. 2). These sites were within open-water long-term depositional areas and distant from channels that might carry highvelocity, erosive flows. Samples were carefully scooped under shallow water from the top 2 to 3 in. of sediment, packed in ice and shipped to the USGS National Water Quality Laboratory in Arvada, Colo., and analyzed by methods described by Shelton and Capel (1994) and Radtke (1997). The sediment fraction with particle sizes less than $2 \mathrm{~mm}$ (sand size and smaller), which constituted 100 percent of each sample, was analyzed for (1) polycyclic aromatic hydrocarbons by gas chromatography with a massspectrometric detector, and (2) organochlorine compounds by gas chromatography with electroncapture detectors as described in Wershaw and others (1987). The clay fraction (particle size less than 63 micrometers) was analyzed for major and trace elements following procedures listed in Timme (1995) and described in Fishman and Friedman (1989).

\section{Flora Survey, Plant-Tissue Analyses, and Biomass Measurements}

Wetland-flora studies conducted during 1991 and 1996 included (1) identification of individual species, (2) mapping of plant communities, (3) measurements of cattail density and above- and belowground biomass, and (4) chemical analyses of aboveand below-ground tissues of cattails. During the 1991 study, flora identification and mapping, and measurements of cattail density, were conducted on June 5 and July 5; cattail tissues for biomass calculations and chemical analyses were collected between August 15 and September 10. All components 
of the 1996 study were conducted between July 25 and August 25.

Two permanent transects (fig. 2) were established-one across the southern part of the wetland, and one across the northern part-along which $3.3-\mathrm{ft}^{2}\left(1-\mathrm{m}^{2}\right)$ plots were established every $33 \mathrm{ft}$ $(10 \mathrm{~m})$ and marked with 1.5-in. PVC pipe. The height of cattail shoots, the cattail density, the percentage of plot surface covered by cattails, and the water depth were measured at each of 31 plots across the southern transect and 26 plots across the northern transect. Only 20 plots were sampled along the northern transect in 1996. Samples of above-ground tissues were harvested from a $3.3-\mathrm{ft}^{2}\left(1-\mathrm{m}^{2}\right)$ area adjacent to each permanent plot, and samples of below-ground tissues were collected within these areas from a $1.6-\mathrm{ft}^{2}\left(0.5-\mathrm{m}^{2}\right)$ area to a depth of about $12 \mathrm{in} .(30 \mathrm{~cm})$. Each sample was washed free of sediment and debris, then air-dried and weighed, and the biomass per unit area was computed. Unusually high water levels and hazardous walking conditions in the field necessitated modification of the above protocols for biomass collection across the northern transect during the 1991 study. At that time and location, a representative sample of above-ground biomass ( 2 or 3 cattail shoots) was collected adjacent to each permanent plot, and the rhizomes and roots of these harvested cattails were used for the below-ground biomass sample. After drying and weighing, the above-ground biomass per unit area was computed as the product of the average weight per shoot and the number of shoots in the adjacent permanent plot. The below-ground biomass per unit area was calculated similarly from the average rhizome-plus-root weight per shoot. This method of calculation was reported to give reliable results for a Carex sp. (sedge) wetland in New York (Bernard and Gorham, 1978).

Prior to drying, a small subsample of each aboveand below-ground sample was processed for chemical analysis. These subsamples were washed in a solution of detergent and 0.4 percent hydrochloric acid for 30 seconds, rinsed twice in distilled water, oven-dried at $70^{\circ} \mathrm{C}$, and ground in a Wiley mill with a 40-mesh screen. Samples were composited on the basis of soil wetness at the permanent plots, and at least three composite samples from each of three "wetness" environments (dry, shallow-water, and deep-water areas) along each transect were analyzed for metals (copper, nickel, chromium, cobalt, molybdenum, zinc, aluminum, iron, boron, manganese, and lead) and nutrients (nitrogen, phosphorus, potassium, calcium, magnesium, and sodium) at the Soil and Plant Testing Laboratory in the Soils, Crops and Atmospheric Sciences Department at Cornell University, Ithaca, N.Y.

\section{Quality-Assurance and Quality-Control Program}

Much of the data presented in this report were collected and analyzed by the MCEHL, whose responsibilities included (1) measurement of stream discharge and collection of water samples at the streamflow- and water-quality-monitoring stations, and (2) analysis of the water samples. A qualityassurance and quality-control (QA/QC) program was established to ensure that the data collected by MCEHL met USGS standards. QA/QC for discharge measurements included (1) periodic instruction of MCEHL personnel in USGS measurement techniques; (2) monthly review of MCEHL stream-discharge measurements; and (3) semiannual discharge measurements and inspections of the monitoring sites by USGS personnel. The semiannual discharge measurements checked the correctness of MCEHL measurement techniques and the validity of the stageto-discharge relation that had been developed by the USGS for a particular year.

QA/QC for the water-sampling and analysis program included (1) a comparison of constituent concentrations measured in depth-integrated crosssectional samples (manual samples) with those measured concurrently in samples collected with automatic samplers; (2) MCEHL participation in the semiannual USGS Standard Reference Water Sample program for cooperating analytical laboratories; and (3) comparison of results from analyses of split samples by MCEHL and the USGS National Water Quality Laboratory (NWQL) in Denver, Colo.

Automatic water samplers provided nearly continuous water-chemistry data at the wetland inlet and outlet. The reliability of these data depends on how well constituent concentrations in each sample represent the mean concentrations of those constituents across the entire flow area. This representation was evaluated through a statistical test to compare manually collected sample data with the automatically collected sample data to determine whether the mean of the differences between paired data-(manual and automatic)—was significantly different from zero (paired t-test). A significant 
difference would indicate a systematic bias in the data collected by the automatic sampler. Results indicated that (1) the concentrations for total suspended solids (TSS) and total phosphorus (TP) in the automatically collected samples at Blossom Road were significantly greater $(\mathrm{p}$-value $=0.0001)$ than those in manually collected samples, and (2) the ammonia-nitrogen $\left(\mathrm{NH}_{3}\right)$ concentrations in automatically collected samples at Empire Boulevard were significantly less ( $\mathrm{p}$-value $=0.0017)$ than those in manually collected samples. No other significant differences $(\alpha=0.05)$ between concentrations obtained with the two methods were detected for any other constituent at Blossom Road or Empire Boulevard.

The higher concentrations of TSS and TP in automatically collected samples than in the manual samples from the Blossom Road site could have reflected the location and position of (1) the gage, which was at a point where the channel slope and, hence, flow velocity were decreasing; (2) the water intake, which was in the channel thalweg such that it was close to the bottom during medium and highstage flows (repositioning of the intake in the water column would have jeopardized collection of lowstage samples); and (3) the manual-samplecollection site for high flows, which was about 3,500 feet downstream from the automatic-samplecollection site-a distance that, given the decrease in gradient, would allow removal of suspended sediment and adsorbed chemicals through settling or overbank deposition. These discrepancies would cause the computed loads and removal efficiencies of these constituents calculated for the automatically collected samples to be larger than those calculated for the manually collected samples. The suggested causes for these discrepancies are plausible, and except in extreme floods, the automatically collected samples might reflect the concentrations of these constituents more accurately than the manually collected samples.

The higher ammonia concentrations in the depth-integrated manually collected samples than in the automatically collected samples from the Empire Boulevard site could have resulted from the inclusion of water with high ammonia concentrations near the bottom of the channel (generated by ammonification of decomposing organic matter in the bed sediments) in the manually collected samples. A similar vertical difference in ammonia concentration was reported in a wastewater-treatment pond by Davido and Conway
(1989). The $\mathrm{NH}_{3}$ output load computed from the automatically collected samples is significantly larger than the computed input load; the negative removal efficiency for this constituent indicates that the wetland is a source of $\mathrm{NH}_{3}$. The $\mathrm{NH}_{3}$ concentrations in the manually collected samples suggest that $\mathrm{NH}_{3}$ output loads should be larger than those computed from the concentrations in the automatically collected samples. The computed loads could have been adjusted to account for this discrepancy, but was not done because, even though the magnitude of the difference between input and output loads would increase, it would not affect the conclusion that the wetland is a source of $\mathrm{NH}_{3}$.

MCEHL participated in the semiannual USGS Standard Reference Sample (SRS) program, wherein reference samples were submitted to participating laboratories by USGS for analysis for trace constituents, major constituents, and nutrients. The analytical results from all participating laboratories were transmitted to USGS, and a "most probable value" (MPV) was statistically calculated for each constituent. MCEHL results were consistently rated "satisfactory" to "good" (within 1.50 to 0.51 standard deviations of the MPV) for trace elements; and "good" to "excellent" (within 1.00 to 0.00 standard deviations of the MPV) for major ions, nutrients, and mercury, and for analyses of low-ionic strength samples, which simulated precipitation.

An additional check on the analytical accuracy of MCEHL included the analyses of samples by both MCEHL and NWQL and comparison of the results. Samples collected on September 18, 1991, and October 20,1993, were divided into eight equal parts (split samples), and four subsamples were analyzed by each laboratory for dissolved or total ammonia-plusorganic nitrogen, nitrate-plus-nitrite, and total phosphorus. The results of paired t-tests, conducted on the analytical data from samples collected at all USGS stations in the Monroe County monitoring network to identify statistically significant differences between the two laboratories for specific constituents, are given in Sherwood (1997). Of the samples collected on September 18, 1991, only nitrate-plus-nitrite concentrations differed significantly between the two laboratories, and of the samples collected on October 20, 1993, only total ammonia-plus-organic nitrogen and total phosphorus concentrations showed significant differences. P-values associated with these tests of significance were not presented in Sherwood 
(1997). No conclusions from these comparisons have been drawn because only two split samples were analyzed during the 6-year study period, and the results were inconsistent.

\section{Computation of Constituent Loads and Removal Efficiency}

Monthly and annual constituent loads at the two water-quality-monitoring stations were calculated with the USGS program, Estimator (G. Baier, T. Cohn, and E. Gilroy, U.S. Geological Survey, written commun., 1995), which is based on a log-linear regression model that relates nutrient concentrations to surrogate variables of discharge, time (year and decimal-date), and season (Cohn and others, 1989; 1992). Nine variables were considered for each model: a constant; a quadratic fit to the logarithm of discharge (log flow and square of log flow); a quadratic fit to time (decimal time and square of decimal time); and two sinusoidal (first- and second-order Fourier) functions to account for the effects of annual seasonality (Cohn and others, 1992). Data from the entire period of study (October 1990 through September 1996) were used to develop the load model for each constituent at each sampling site. For a given constituent, if the coefficient for a variable was found to be significantly different from zero ( $p$-value less than 0.05 ) for either the input or output load models, it was included in both models to maintain comparability of the results from both models (table 3 ). The constituent loads were computed from continuous water-quality (composited hourly samples) and flow data-typically, at least two samples were provided per week, but more were obtained if a storm occurred. Typically, stormwater samples were composited in a similar manner at both sites; one sample each for the rising and falling stages and one or two samples during the peak. The discharge associated with a given water sample was computed as the mean of the 15-minute discharges indicated by the stage-to-discharge relation at the Blossom Road monitoring station and the stage-and-velocity-todischarge relation at the Empire Boulevard site for the period covered by the hourly water samples that were composited into the analyzed sample. Daily loads were computed by the load model from the daily mean discharges recorded at each site. From these data, total monthly, annual, and period-of-record loads were computed for nitrogen and phosphorus compounds, chloride, sulfate, and suspended solids. (See appendix 2.) The precision of the estimated loads can be described in terms of a confidence interval, which is based on the estimated mean and the standard error of

Table 3. Explanatory variables used in regression models developed to compute constituent loads for Irondequoit Creek above Blossom Road (wetland inlet) and at Empire Boulevard (wetland outlet), Monroe County, N.Y., $1990-96$

[Coefficient for a specified variable was found to be significantly different from zero (p-value less than 0.05) for one or both of the input- and output-load models. If, for a given constituent, a variable was significant for only one of the load models, it was nevertheless used in both models to maintain comparability of the models' results.]

\begin{tabular}{|c|c|c|c|c|c|c|c|c|c|}
\hline \multirow[b]{3}{*}{ Constituent } & \multicolumn{9}{|c|}{ Explanatory Variable } \\
\hline & \multirow[b]{2}{*}{ Constant } & \multirow{2}{*}{$\begin{array}{l}\text { Log } \\
\text { flow }\end{array}$} & \multirow{2}{*}{$\begin{array}{l}\text { Log flow } \\
\text { squared }\end{array}$} & \multirow{2}{*}{$\begin{array}{l}\text { Decimal } \\
\text { time }\end{array}$} & \multirow{2}{*}{$\begin{array}{l}\text { Decimal } \\
\text { time } \\
\text { squared }\end{array}$} & \multicolumn{4}{|c|}{ Seasonality function ( $\mathrm{T}$, time, in years) } \\
\hline & & & & & & $\operatorname{Sin}(2 \pi T)$ & $\operatorname{Cos}(2 \pi \mathrm{T})$ & $\operatorname{Sin}(4 \pi T)$ & $\operatorname{Cos}(4 \pi T)$ \\
\hline \multicolumn{10}{|l|}{ Total nitrogen, as $\mathrm{N}^{1}$} \\
\hline Ammonia-plus-organic nitrogen, as $\mathrm{N}$ & $\mathrm{X}$ & $\mathrm{X}$ & & $\mathrm{X}$ & & $\mathrm{X}$ & $\mathrm{X}$ & $\mathrm{X}$ & $\mathrm{X}$ \\
\hline Ammonia nitrogen, as $\mathrm{N}$ & $\mathrm{X}$ & $\mathrm{X}$ & & $\mathrm{X}$ & & $\mathrm{X}$ & $\mathrm{X}$ & $\mathrm{X}$ & $\mathrm{X}$ \\
\hline \multicolumn{10}{|l|}{ Organic nitrogen, as $\mathrm{N}^{1}$} \\
\hline Nitrate plus nitrite, as $\mathrm{N}$ & $\mathrm{X}$ & $\mathrm{X}$ & $\mathrm{X}$ & $\mathrm{X}$ & $\mathrm{X}$ & $\mathrm{X}$ & $\mathrm{X}$ & $\mathrm{X}$ & $\mathrm{X}$ \\
\hline Total phosphorus, as $\mathrm{P}$ & $\mathrm{X}$ & $\mathrm{X}$ & $\mathrm{X}$ & $\mathrm{X}$ & $\mathrm{X}$ & $\mathrm{X}$ & $\mathrm{X}$ & & \\
\hline Orthophosphate, as $\mathrm{P}$ & $\mathrm{x}$ & $\mathrm{X}$ & $\mathrm{x}$ & $\mathrm{X}$ & $\mathrm{x}$ & $\mathrm{x}$ & $\mathrm{x}$ & $\mathrm{X}$ & $\mathrm{x}$ \\
\hline Total suspended solids & $\mathrm{X}$ & $\mathrm{X}$ & & $\mathrm{X}$ & $\mathrm{X}$ & $\mathrm{X}$ & $\mathrm{X}$ & & \\
\hline Volatile suspended solids & $\mathrm{X}$ & $\mathrm{X}$ & & $\mathrm{X}$ & $\mathrm{X}$ & $\mathrm{X}$ & $\mathrm{X}$ & & \\
\hline \multicolumn{10}{|l|}{ Nonvolatile suspended solids 1} \\
\hline Chloride & $\mathrm{X}$ & $\mathrm{X}$ & $\mathrm{X}$ & $\mathrm{X}$ & & $\mathrm{X}$ & $\mathrm{X}$ & $\mathrm{X}$ & $\mathrm{X}$ \\
\hline Sulfate & $\mathrm{X}$ & $\mathrm{X}$ & $\mathrm{X}$ & $\mathrm{X}$ & $\mathrm{X}$ & & & & \\
\hline
\end{tabular}

${ }^{1}$ Loads for this constituent were not computed from a regression model. 
prediction calculated by the equation. At a 95-percent confidence interval $(\alpha=0.05)$, the confidence limits are the estimated load \pm 1.96 times the standard error of prediction (appendix 2).

Potential problems in calculating loads based on regression models include multiply censored waterquality data, logarithm retransformation bias, and lack of fit between predicted and observed values. The Estimator program handles multiply censored data through an adjusted maximum-likelihood estimation procedure (Cohn, 1988; 1995). Loads computed from the logarithm of constituent concentrations can show bias when the loads are transformed back into nonlogarithmic units. This bias, which tends to underestimate the loads, is corrected in the Estimator program by a minimum-variance unbiased estimator (Cohn, 1988; 1995; Cohn and others, 1992).

Misspecification of a regression model, which is likely to result when linear regression is used to describe the relation among time-series data, can be indicated by serial correlation (non-independence) of the residuals. In the Estimator program, serial correlation of residuals and the effect of seasonality is minimized by inclusion of sinusoidal functions of time $(\sin 2 \pi \mathrm{T}$, $\cos 2 \pi \mathrm{T}, \sin 4 \pi \mathrm{T}, \cos 4 \pi \mathrm{T}$, where $\mathrm{T}$ is time, in years) (Cohn and others, 1992). Lack of fit of a regression model can be indicated by low coefficients of determination and nonnormal distribution and serial correlation of the residuals. Cohn and others (1992) point out that (1) load estimators based on log-linear models, in general, appear to be relatively insensitive to violations of the assumptions of linear regression, that is, nonnormality and independence of the residuals; (2) a minimum variance unbiased estimator, in particular, which is based on the assumptions of a log-linear model, provides good estimates of loads despite these violations; and (3) the variances of annual or monthly load estimates based on infrequent sampling appear to be well described by log-linear model theory. Model validity or goodness of fit was evaluated by regression diagnostic statistics — standard error of prediction (appendix 2), coefficient of determination, and probability plot-correlation coefficient as a measure of the normality of the residuals-with consideration given to the number of total and censored observations included in the development of each model (table 4).

The effectiveness of the wetland in decreasing chemical loads can be evaluated in terms of removal efficiency - the percentage of an input load that is retained in, or exported from, the wetland. Removal efficiency for a given constituent was computed as the ratio of the difference between input and output load to the input load, expressed as a percentage. Monthly and annual removal efficiencies were computed for each constituent. A positive value indicated a net retention of a constituent in the wetland, and a negative value indicated the generation of a constituent within the wetland (or, possibly, its adjacent drainage area) and a net export of a constituent.

Statistical analyses were conducted through SAS (SAS Institute, Inc., 1989; 1990). Most of the monthly load and removal-efficiency data did not show normal distributions; therefore, nonparametric tests were used to analyze the data. Statistically significant differences between the monthly input and output loads were identified by the Wilcoxon signedranks test on the ranked differences between the paired (input and output) loads (table 5). This test indicated whether the mean of the differences between input and output loads was significantly different from zero.

As a measure of the strength of association between variables, Spearman correlation coefficients were computed between monthly efficiencies and loads, and season and monthly mean discharges and water-surface elevations (table 6). A numeric dummy variable was used for "season" as follows: (1) October through November, when plant senescence occurs, and water levels in the wetland drop in response to the lowering of Lake Ontario in anticipation of storage requirements during spring runoff; (2) December through February, when stream discharges and water levels are generally low; (3) March and April, when stream discharges are usually greatest, and water levels begin to rise in the lake and the wetland; and (4) May through September, when water levels are high, and stream discharges can vary substantially. The season variable was used to assess the wetland's water-quality-improvement function that could be attributed to nutrient uptake and release by wetland vegetation and microbes. The combined variables - season and monthly mean discharge and water-surface elevation-were used as surrogate variables to assess the effect of the duration and depth of wetland inundation on wetland processes.

Frequency of inundation, which could be quantified by the number of overbank flows that occurred during a given month, was not included in this analysis because (1) overbank flows occurred infrequently (from zero to four times a year), and (2) the regulated water level in 
Table 4. Regression statistics for models used to compute constituent loads for Irondequoit Creek above Blossom Road (wetland inlet) and at Empire Boulevard (wetland outlet), Monroe County, N.Y., 1990-96

[Dash indicates no data. Locations are shown in fig. 2.]

\begin{tabular}{|c|c|c|c|c|c|c|}
\hline Constituent & $\begin{array}{c}\text { Number } \\
\text { of } \\
\text { observations }\end{array}$ & $\begin{array}{c}\text { Number of } \\
\text { censored } \\
\text { observations }\end{array}$ & $\begin{array}{l}\text { Coefficient } \\
\text { of determi- } \\
\text { nation }^{1}\end{array}$ & $\begin{array}{l}\text { Residuals } \\
\text { probability } \\
\text { plot } \\
\text { correlation } \\
\text { coefficient }^{2}\end{array}$ & $\begin{array}{l}\text { Standard } \\
\text { error of } \\
\text { regression }\end{array}$ & $\begin{array}{l}\text { Serial } \\
\text { correlation } \\
\text { of } \\
\text { residuals }^{4}\end{array}$ \\
\hline \multicolumn{7}{|l|}{ Blossom Road } \\
\hline Total nitrogen, as $\mathrm{N}^{5}$ & -- & -- & -- & -- & -- & -- \\
\hline Ammonia-plus-organic nitrogen, as $\mathrm{N}$ & 1016 & 1 & 0.850 & 0.988 & 0.379 & 0.375 \\
\hline Ammonia nitrogen, as $\mathrm{N}$ & 985 & 440 & .571 & .955 & .865 & .449 \\
\hline Organic nitrogen, as $\mathrm{N}^{5}$ & -- & -- & -- & -- & -- & -- \\
\hline Nitrate plus nitrite, as $\mathrm{N}$ & 1007 & 0 & .938 & .948 & .216 & .633 \\
\hline Total phosphorus, as $\mathrm{P}$ & 1021 & 0 & .745 & .988 & .665 & .299 \\
\hline Orthophosphate, as $\mathrm{P}$ & 1022 & 3 & .749 & .989 & .483 & .501 \\
\hline Total suspended solids & 313 & 4 & .671 & .981 & .806 & .137 \\
\hline Volatile suspended solids & 309 & 21 & .648 & .986 & .725 & .228 \\
\hline Nonvolatile suspended solids ${ }^{5}$ & -- & -- & -- & -- & -- & -- \\
\hline Chloride & 1028 & 0 & .931 & .973 & .192 & .582 \\
\hline Sulfate & 1015 & 1 & .847 & .933 & .175 & .159 \\
\hline \multicolumn{7}{|l|}{ Empire Boulevard } \\
\hline Total nitrogen, as $\mathrm{N}^{5}$ & -- & -- & -- & -- & -- & -- \\
\hline Ammonia-plus-organic nitrogen, as $\mathrm{N}$ & 875 & 0 & .883 & .993 & .298 & .510 \\
\hline Ammonia nitrogen, as $\mathrm{N}$ & 857 & 100 & .502 & .986 & .715 & .580 \\
\hline Organic nitrogen, as $\mathrm{N}^{5}$ & -- & -- & -- & -- & -- & -- \\
\hline Nitrate plus nitrite, as $\mathrm{N}$ & 875 & 0 & .957 & .992 & .188 & .625 \\
\hline Total phosphorus, as $\mathrm{P}$ & 886 & 0 & .837 & .980 & .439 & .421 \\
\hline Orthophosphate, as $\mathrm{P}$ & 887 & 1 & .866 & .981 & .321 & .536 \\
\hline Total suspended solids & 233 & 3 & .745 & .984 & .623 & .228 \\
\hline Volatile suspended solids & 232 & 28 & .762 & .987 & .493 & .293 \\
\hline Nonvolatile suspended solids ${ }^{5}$ & -- & -- & -- & -- & -- & -- \\
\hline Chloride & 890 & 0 & .933 & .977 & .196 & .599 \\
\hline Sulfate & 874 & 0 & .877 & .978 & .160 & .274 \\
\hline
\end{tabular}

${ }^{1}$ Coefficient of determination $\left(\mathrm{R}^{2}\right)$ : the proportion of the total variance in computed loads that is accounted for by regression model.

${ }^{2}$ Probability-plot correlation coefficient: a measure of the likelihood that the residuals are normally distributed. A value greater than 0.97 implies that the data are from a population with a normal distribution.

${ }^{3}$ Standard error of regression: a measure of the dispersion of the data around the regression line.

${ }^{4}$ Serial correlation of residuals: a measure of the dependence or correlation in time sequence between residuals. Serial correlation coefficient ranges from zero (no serial correlation) to 1.00 (strong serial correlation).

${ }^{5}$ Loads for this constituent were not computed from a regression model.

this system would have obscured any short-term effects from overbank flows. Correlation coefficients between monthly removal efficiencies, their respective input and output loads, and monthly mean discharges were computed, but some amount of artificial or spurious correlation between these variables was expected because the loads were based on discharges, and removal efficiencies were based on loads. 
Table 5. Statistics ( $p$ values) related to tests of significant difference between monthly constituent loads computed for Irondequoit Creek above Blossom Road (wetland inlet) and at Empire Boulevard (wetland outlet), Monroe County, N.Y., 1990-96

[Statistics are based on differences between monthly paired data; that is, input (Blossom Road) load minus output (Empire Boulevard) load. Dash indicates test is inappropriate for nonnormally distributed data, or that no conclusion can be stated.]

\begin{tabular}{|c|c|c|c|c|c|}
\hline \multirow[b]{2}{*}{ Constituent } & \multirow{2}{*}{$\begin{array}{c}\text { Shapiro-Wilk } \\
\text { test of } \\
\text { normality } \\
\text { (p-value) }\end{array}$} & \multicolumn{2}{|c|}{$\begin{array}{c}\text { Tests of significance } \\
\text { (p-value) }\end{array}$} & \multirow[b]{2}{*}{$\begin{array}{l}\text { Significant } \\
\text { difference }\end{array}$} & \multirow[b]{2}{*}{$\begin{array}{c}\text { Location } \\
\text { of greater } \\
\text { load }\end{array}$} \\
\hline & & $\begin{array}{l}\text { Paired- } \\
\text { difference } \\
\text { t-test }\end{array}$ & $\begin{array}{c}\text { Wilcoxon } \\
\text { Signed ranks } \\
\text { test }\end{array}$ & & \\
\hline Total nitrogen, as $\mathrm{N}$ & 0.0001 & -- & 0.0028 & yes & inflow \\
\hline Ammonia-plus-organic nitrogen, as $\mathrm{N}$ & .0001 & -- & .1005 & no & -- \\
\hline Ammonia nitrogen, as $\mathrm{N}$ & .1358 & .0001 & .0001 & yes & outflow \\
\hline Organic nitrogen, as $\mathrm{N}$ & .0001 & -- & .0006 & yes & inflow \\
\hline Nitrate plus nitrite, as $\mathrm{N}$ & .0030 & -- & .0163 & yes & inflow \\
\hline Total phosphorus, as $\mathrm{P}$ & .0001 & -- & .0001 & yes & inflow \\
\hline Orthophosphate, as $\mathrm{P}$ & .0001 & -- & .0001 & yes & outflow \\
\hline Total suspended solids & .0001 & -- & .0001 & yes & inflow \\
\hline Volatile suspended solids & .0001 & -- & .0001 & yes & inflow \\
\hline Nonvolatile suspended solids & .0001 & -- & .0001 & yes & inflow \\
\hline Chloride & .0019 & -- & .0001 & yes & outflow \\
\hline Sulfate & .0692 & .0024 & .0007 & yes & inflow \\
\hline
\end{tabular}

\section{EFFECTS OF WETLAND ON WATER QUALITY}

Chemical concentrations in a stream are affected by the volume of flow at the time the sample is collected. Concentrations (mass per volume) of constituents in the dissolved phase generally decrease through dilution as flow increases, whereas the loads (total mass) of these constituents generally increase during high flows. Dissolved constituents in the Ellison Park wetland, such as ammonia nitrogen $\left(\mathrm{NH}_{3}\right)$, generally followed this pattern. The range of ammonia-nitrogen concentrations, and the maximum concentrations (fig. 5A), were greater during low flows $(0.01$ to $0.66 \mathrm{mg} / \mathrm{L})$ than during high flows $(0.01$ to $0.09 \mathrm{mg} / \mathrm{L}$ ), and, similarly, the maximum concentrations of orthophosphate were greater during low flows $(0.12 \mathrm{mg} / \mathrm{L})$ than during high flows $(0.03 \mathrm{mg} / \mathrm{L})$. Concentrations of constituents in the particulate phase generally increase with increasing flow, as do their corresponding loads, when the sediment and organic matter to which these constituents adsorb is washed into the stream by overland flow or resuspended from the channel bottom by turbulence. The concentration-to-flow relations for constituents in the Ellison Park wetland that are associated with particulate matter, such as total phosphorus (TP; fig. 5B), show discrepancies, however. The concentrations of TP in most low-flow samples clustered between 0 and $0.4 \mathrm{mg} / \mathrm{L}$ but in some samples were as high as $1.5 \mathrm{mg} / \mathrm{L}$. Generally, TP concentrations increased with increasing discharge to the 700 - to $900-\mathrm{ft}^{3} / \mathrm{s}$ flow range, at least at the Blossom Road (inflow) site, then decreased as discharge increased further. These apparent discrepancies might be explained by (1) the time of sample collection in relation to the peak discharge for a given storm, and (2) the duration of high flows prior to collection of a sample. Despite these discrepancies in the concentration-to-flow relation for particulate constituents, the loads of these chemicals were directly related to discharge (table 6).

The effectiveness of any wetland in decreasing chemical loads depends on the balance between chemical-removal and chemical-generation processes because this balance determines whether a wetland acts as a sink or a source of a given constituent at a given time. In general, the Ellison Park wetland had little effect on the surface-water concentrations and loads of dissolved constituents, except ammonia nitrogen and orthophosphate, which were generated by 
Table 6. Spearman correlation coefficients between constituent loads and removal efficiencies and four variables, Ellison Park wetland, Monroe County, N.Y., 1990-96

\begin{tabular}{|c|c|c|c|c|}
\hline \multirow[b]{2}{*}{ Constituent } & \multicolumn{4}{|c|}{ Variables } \\
\hline & $\begin{array}{c}\text { Monthly } \\
\text { mean discharge } 1\end{array}$ & Season $^{2}$ & $\begin{array}{l}\text { Monthly mean } \\
\text { water-surface } \\
\text { elevation }\end{array}$ & $\begin{array}{l}\text { Removal } \\
\text { efficiency }\end{array}$ \\
\hline \multicolumn{5}{|l|}{ LOADS } \\
\hline Total nitrogen, input & 0.98 & -0.20 & 0.25 & 0.30 \\
\hline Total nitrogen, output & .98 & -.27 & .16 & .18 \\
\hline Ammonia-plus-organic nitrogen, input & .96 & -.13 & .32 & .67 \\
\hline Ammonia-plus-organic nitrogen, output & .96 & -.17 & .27 & .57 \\
\hline Ammonia nitrogen, input & .90 & -.18 & .25 & .71 \\
\hline Ammonia nitrogen, output & .88 & -.17 & .17 & .13 \\
\hline Organic nitrogen, input & .96 & -.13 & .32 & .59 \\
\hline Organic nitrogen, output & .95 & -.17 & .27 & .46 \\
\hline Nitrate-plus-nitrite nitrogen, input & .96 & -.24 & .19 & -.20 \\
\hline Nitrate-plus-nitrite nitrogen, output & .96 & -.33 & .07 & -.34 \\
\hline Total phosphorus, input & .87 & .06 & .41 & .55 \\
\hline Total phosphorus, output & .79 & .12 & .47 & .30 \\
\hline Orthophosphate, input & .79 & -.06 & .27 & .25 \\
\hline Orthophosphate, output & .78 & .00 & .33 & .04 \\
\hline Total suspended solids, input & .93 & .00 & .38 & .35 \\
\hline Total suspended solids, output & .89 & -.02 & .36 & .12 \\
\hline Volatile suspended solids, input & .94 & -.05 & .34 & .41 \\
\hline Volatile suspended solids, output & .92 & -.17 & .24 & .12 \\
\hline Nonvolatile suspended solids, input & .93 & .01 & .38 & .33 \\
\hline Nonvolatile suspended solids, output & .88 & .00 & .38 & .10 \\
\hline Chloride, input & .91 & -.34 & .06 & -.04 \\
\hline Chloride, output & .92 & -.36 & .01 & -.13 \\
\hline Sulfate, input & .99 & -.19 & .25 & -.05 \\
\hline Sulfate, output & .99 & -.22 & .19 & -.20 \\
\hline \multicolumn{5}{|l|}{ REMOVAL EFFICIENCIES } \\
\hline Total nitrogen & .31 & .47 & .59 & 1.00 \\
\hline Ammonia-plus-organic nitrogen & .64 & .11 & .44 & 1.00 \\
\hline Ammonia nitrogen & .45 & -.10 & .19 & 1.00 \\
\hline Organic nitrogen & .59 & .13 & .42 & 1.00 \\
\hline Nitrate-plus-nitrite nitrogen & -.18 & .67 & .59 & 1.00 \\
\hline Total phosphorus & .54 & -.11 & .05 & 1.00 \\
\hline Orthophosphate & .15 & -.18 & -.08 & 1.00 \\
\hline Total suspended solids & .30 & .02 & .07 & 1.00 \\
\hline Volatile suspended solids & .32 & .31 & .30 & 1.00 \\
\hline Nonvolatile suspended solids & .29 & -.02 & .03 & 1.00 \\
\hline Chloride & .14 & .19 & .32 & 1.00 \\
\hline Sulfate & -.06 & .24 & .23 & 1.00 \\
\hline
\end{tabular}

\footnotetext{
${ }^{1}$ Measured at Irondequoit above Blossom Road (wetland inlet)).
}

${ }^{2}$ Season was defined by a numeric value: 1 = October-November,; 2 = December-February, 3 = March-April, and 4 = May-September. 
wetland processes and exported from the wetland in quantities larger than those which entered the wetland. Conversely, the wetland facilitated a substantial decrease in particulate constituents, such as suspended solids and total phosphorus, through sedimentation and vegetative filtration.

\section{Constituent Loads and Removal Efficiencies}

Two factors that could have affected the calculated constituent loads and removal efficiencies for the Ellison Park wetland were chemical inputs from atmospheric deposition and ground water. Atmospheric deposition was collected monthly in the northern part of the wetland, about $1,700 \mathrm{ft}$ south of Empire Boulevard (fig. 2). Precipitation-quality data are given in Coon (1997) or in the annual USGS water-resources-data reports for western New York State, for example, Hornlein and others (1997). Kappel and others (1986) noted that atmospheric deposition in the Irondequoit Creek basin is a significant source of chemicals and, except for chloride, can make substantial contributions to chemical loads in the creek. Atmospheric-deposition sampling has inherent uncertainties that are related to
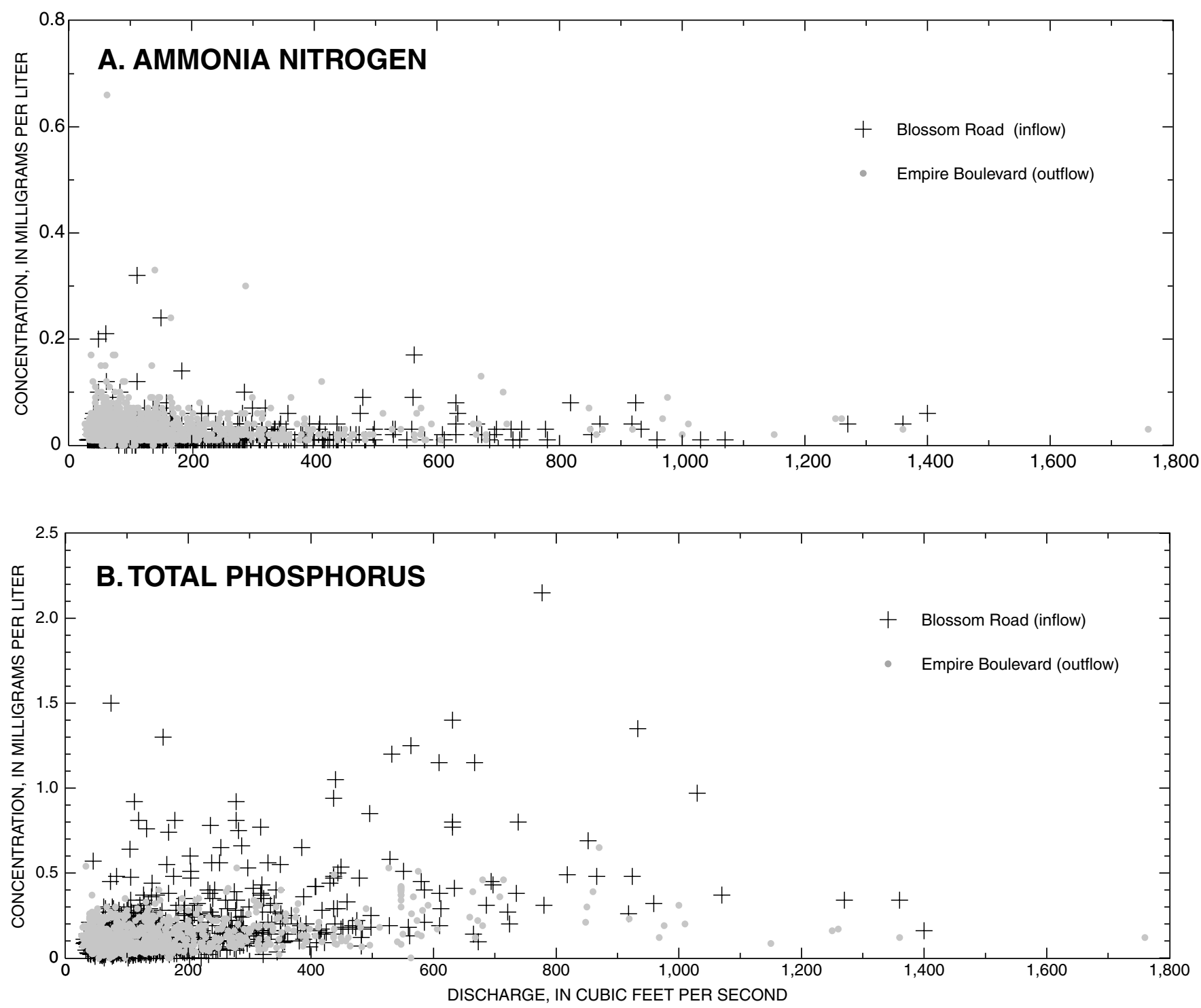

Figure 5. Concentration of $(A)$ a dissolved constituent (ammonia nitrogen), and (B) a particulate constituent (total phosphorus) as a function of discharge in Irondequoit Creek above Blossom Road and at Empire Boulevard, Monroe County, N.Y., 1990-96 
possible contamination by wildlife (primarily birds), areal variability in precipitation and dryfall, and a lack of information on the interactions and fate of chemicals after deposition; therefore, Kappel and others (1986) cautioned against using chemical contributions from atmospheric sources to compute seasonal rates of deposition, accumulation, or washoff to streams. Furthermore, atmospheric deposition that falls directly on freshwater marshes dominated by surface-water inflow is a relatively small source of nutrients (Mitsch and Gosselink, 1986). The Ellison Park wetland is surface-water dominated, and the difference in drainage area between the inflowsampling site above Blossom Road $\left(142 \mathrm{mi}^{2}\right)$ and the outflow-sampling site at Empire Boulevard $\left(151 \mathrm{mi}^{2}\right)$ is only 6 percent; therefore, chemical inputs from atmospheric deposition were considered too small to affect the results of this study.

Ground-water levels and chemical quality in Ellison Park were measured at nine observation wells in the vicinity of Browncroft Boulevard and Blossom Road (fig. 2) (not in the cattail-covered area of the wetland). Ground-water levels and ground-waterquality data are given in Coon (1997) or in the annual USGS water-resources-data reports for western New York State, for example, Hornlein and others (1997). The Ellison Park wetland is a regional and local ground-water-discharge area (Yager and others, 1985), but no studies to date have been conducted to map ground-water movement in the wetland, measure ground-water-discharge rates, define the interactions between ground water, surface water, and atmospheric deposition, or to compute chemical loads that enter the wetland from ground water. Groundwater contributions to nutrient loads in freshwater wetlands dominated by surface-water flow are reported to be relatively small (Mitsch and Gosselink, 1986); therefore, surface-water output loads from the Ellison Park wetland were not adjusted for inputs from this source.

Monthly and annual surface-water loads of selected constituents at the Ellison Park wetland inflow and outflow monitoring sites (Irondequoit Creek above Blossom Road and at Empire Boulevard, respectively) are presented in appendix 2; the monthly and annual removal efficiencies for each constituent are given in appendix 3 . The average annual input and output loads, and the annual and period-of-study removal efficiencies for each of these constituents are summarized in table 7 . The following sections describe the effect of the wetland on loads of nitrogen, phosphorus, suspended solids, chloride, and sulfate, and the wetland's removal efficiency for each. Note that:

1. The method used to compute loads is an estimation technique, where results have been shown to compare reasonably well with observed loads (Cohn and others, 1992).

2. Loads and removal efficiencies are based on annual and period-of-study results, and tests of significance are based on the differences between the monthly input and output loads.

3. Removal efficiencies are computed in relation to the input loads; therefore, large absolute values must be analyzed in relation to the constituent mass that is entering the wetland. Large monthly fluctuations in removal efficiencies, and large negative values during low-flow periods, which suggest a net exportation of a constituent, can be misleading. The monthly removal efficiencies were calculated to indicate seasonal trends (if present) and long-term trends in the capability of the wetland to improve water quality.

\section{Nitrogen}

The mechanisms by which nitrogen can enter a wetland include surface-water or ground-water inflow, atmospheric deposition, and nitrogen fixation-the conversion of nitrogen gas in the atmosphere to ammonia (Kadlec and Knight, 1996). Nitrogen can be stored in live or standing-dead plants, detritus, microbes, wildlife, soils, and in the water column. The amount of nitrogen storage in vegetation changes with plant species, plant part, above- or below-ground tissue, and season (Kadlec and Knight, 1996). Ammonia can be removed from solution through cation-exchange adsorption reactions with detritus and inorganic sediments (Kadlec and Knight, 1996). Burial of organic matter results in long-term storage of nitrogen. Nitrogen can be transformed within a wetland by the processes of (1) ammonification, or mineralization of organic nitrogen to ammonia - the initial step in the microbial breakdown of organic tissues containing amino acids; (2) nitrification-the conversion of ammonia to nitrate under aerobic conditions; (3) denitrification - the reduction of nitrate or nitrite to nitrogen gas under anoxic conditions; and (4) nitrogen assimilation-the conversion of inorganic nitrogen forms to organic compounds for cell and tissue growth (Kadlec and Knight, 1996). Most of 
Table 7. Concentrations and average annual input and output loads, and removal efficiency, for selected constituents, Ellison Park wetland, Monroe County, N.Y.,1990-96

[Inflow and outflow locations are shown in fig. 2. Dash indicates concentration not measured.]

\section{A. Inflow and outflow concentrations (in milligrams per liter) and average annual load (in tons)}

\begin{tabular}{|c|c|c|c|c|c|c|}
\hline \multirow[b]{2}{*}{ Constituent } & \multicolumn{2}{|c|}{ Inflow concentration } & \multicolumn{2}{|c|}{ Outflow concentration } & \multicolumn{2}{|c|}{ Average annual load } \\
\hline & $\begin{array}{l}\text { Interquartile } \\
\text { range }\end{array}$ & Median & $\begin{array}{c}\text { Interquartile } \\
\text { range }\end{array}$ & Median & $\begin{array}{c}\text { Input } \\
\text { (Blossom Rd.) }\end{array}$ & $\begin{array}{c}\text { Output } \\
\text { (Empire Blvd.) }\end{array}$ \\
\hline Total nitrogen & -- & -- & -- & -- & 275 & 263 \\
\hline Ammonia-plus-organic nitrogen & $0.99-0.58$ & 0.77 & $0.98-0.61$ & 0.78 & 126 & 118 \\
\hline Ammonia nitrogen & $0.02-0.01$ & .01 & $0.05-0.02$ & .03 & 2.59 & 4.76 \\
\hline Organic nitrogen & -- & -- & -- & -- & 124 & 114 \\
\hline Nitrate plus nitrite & $1.2-0.79$ & .96 & $1.2-0.73$ & .885 & 149 & 145 \\
\hline Total phosphorus & $0.17-0.055$ & .11 & $0.16-0.06$ & .10 & 26.2 & 19.0 \\
\hline Orthophosphate & $0.016-0.007$ & .011 & $0.023-0.01$ & .016 & 1.69 & 2.33 \\
\hline Total suspended solids & $244-95$ & 139 & $152-73$ & 102 & 28,500 & 15,200 \\
\hline Volatile suspended solids & $30.5-15$ & 21 & $21-12$ & 16 & 3,540 & 2,080 \\
\hline Nonvolatile suspended solids & -- & -- & -- & -- & 24,900 & 13,100 \\
\hline Chloride & $140-95$ & 110 & $140-100$ & 120 & 16,800 & 17,500 \\
\hline Sulfate & $180-110$ & 140 & $170-110$ & 140 & 16,000 & 15,700 \\
\hline
\end{tabular}

B. Removal efficiency, as percentage of input load, by water year ${ }^{1}$

\begin{tabular}{|c|c|c|c|c|c|c|c|}
\hline Constituent & 1991 & 1992 & 1993 & 1994 & 1995 & 1996 & Study period \\
\hline Total nitrogen & 9.6 & -1.8 & 4.6 & 0.3 & 2.7 & 7.6 & 4.3 \\
\hline Ammonia-plus-organic nitrogen & 13.5 & 1.2 & 8.1 & 0 & -3.2 & 8.7 & 6.1 \\
\hline Ammonia nitrogen & 15.3 & -42.2 & -61.8 & -137 & -262 & -315 & -84.0 \\
\hline Organic nitrogen & 13.4 & 2.2 & 9.5 & 2.3 & 1.5 & 13.4 & 8.0 \\
\hline Nitrate plus nitrite & 5.9 & -5.0 & 1.3 & .1 & 6.4 & 6.8 & 2.7 \\
\hline Total phosphorus & 14.5 & 17.1 & 33.0 & 26.0 & 21.1 & 49.0 & 27.6 \\
\hline Orthophosphate & -34.1 & -67.1 & -45.5 & -46.0 & -28.8 & -10.5 & -38.1 \\
\hline Total suspended solids & 31.9 & 40.4 & 51.3 & 51.1 & 49.4 & 58.6 & 46.7 \\
\hline Volatile suspended solids & 28.1 & 34.6 & 43.5 & 43.8 & 42.1 & 55.4 & 41.0 \\
\hline Nonvolatile suspended solids & 32.4 & 41.2 & 52.4 & 52.2 & 50.7 & 59.0 & 47.5 \\
\hline Chloride & 3.4 & -10.6 & -3.7 & -6.8 & -3.2 & -3.8 & -3.9 \\
\hline Sulfate & 7.4 & -2.4 & 1.1 & -.9 & 3.1 & 3.8 & 2.0 \\
\hline
\end{tabular}

${ }^{1}$ Water year is the period from October of one year to September of the following year.

these processes are microbially mediated and, therefore, temperature dependent - that is, in northern wetlands, these processes proceed at faster rates during the summer than during the winter. Nitrogenreleasing processes include decomposition of organic matter, leaching, denitrification, and ammonia desorption (Kadlec and Knight, 1996).

\section{Total Nitrogen}

Total nitrogen (TN) consists of the reduced forms of nitrogen (ammonia and organic nitrogen) and the oxidized forms of nitrogen (nitrate and nitrite). The 6-year average input load of TN in the Ellison Park wetland was 275 tons, whereas the average output load was 263 tons (table 7). Monthly 
input and output loads were similar (fig. 6), but the differences were statistically significant $(\mathrm{p}$-value $=$ 0.0028; table 5) and indicated that the wetland facilitated a small net removal of TN. Annual removal efficiencies for TN ranged from 9.6 to -1.8 percent and averaged 4.3 percent.

\section{Ammonia plus Organic Nitrogen}

Median concentrations of ammonia-plus-organic nitrogen $(\mathrm{TKN})$ at the inflow and outflow were 0.77 and $0.78 \mathrm{mg} / \mathrm{L}$, respectively, and the interquartile ranges at these two sites also were similar (table 7).
Maximum TKN inflow concentrations were often twice as high as the corresponding outflow concentrations, indicating that peak TKN concentrations decreased within the wetland. The 1990-96 plot of TKN concentrations (fig. 7A) indicates a seasonal pattern of high TKN concentrations during the summer and low concentrations during the winter, at least during 1991-94. The average estimated annual input load of TKN was 126 tons, and the average output load was 118 tons (table 7). Annual removal efficiencies ranged from -3.2 to 13.5 percent and averaged 6.1 percent for the study period, but the monthly input and output loads (fig. 7B) did not differ

\section{TOTAL NITROGEN, AS N}
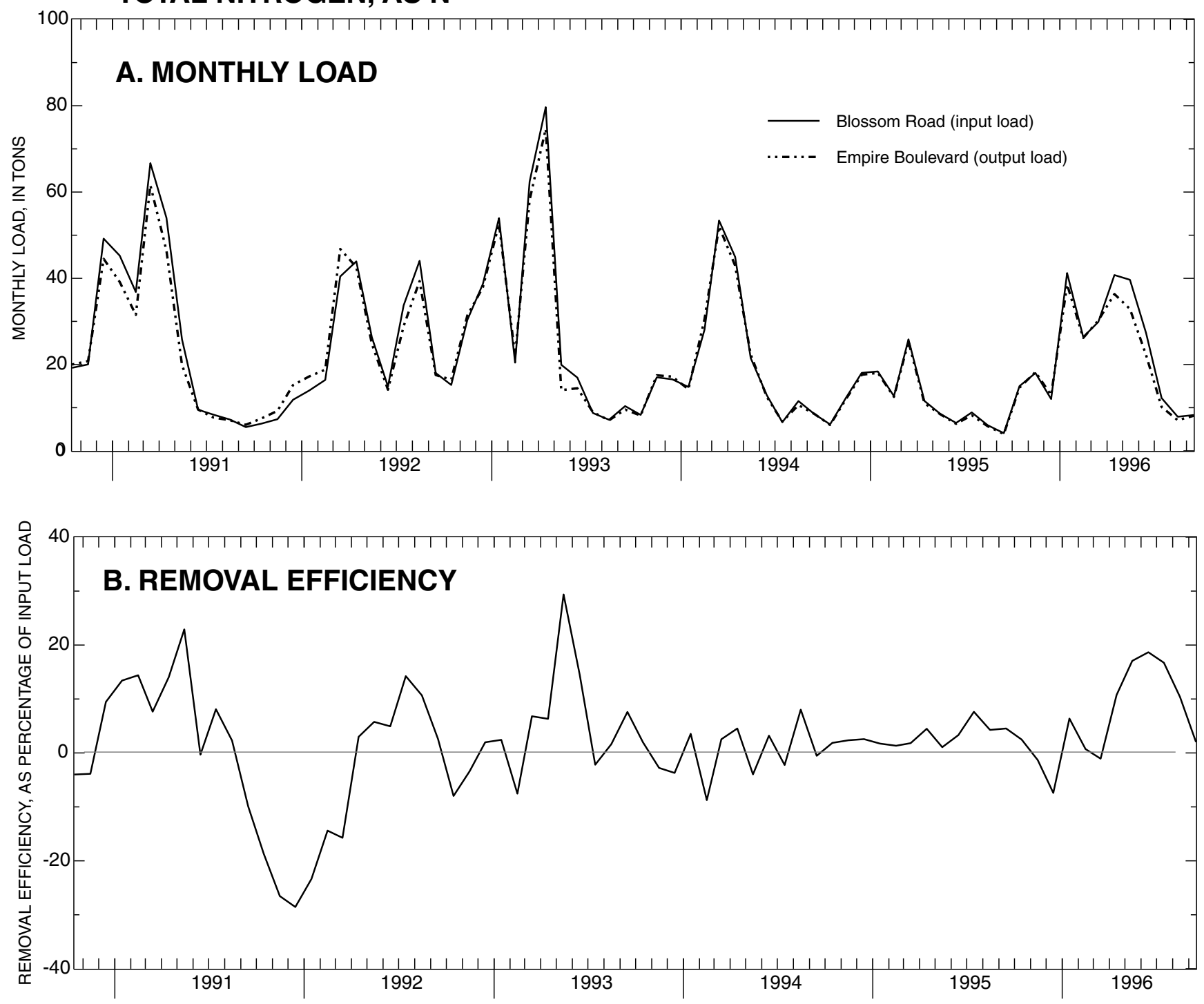

Figure 6. Monthly load and wetland's removal efficiency for total nitrogen, Ellison Park wetland, Monroe County, N.Y., 1990-96 
significantly ( $\mathrm{p}$-value $=0.1005$; table 5). Input loads generally exceeded output loads during high-flow periods, but the two were similar during low-flow periods (fig. 7).

\section{Ammonia Nitrogen}

Concentrations of ammonia $\left(\mathrm{NH}_{3}\right)$ at the inflow (fig. 8A) were typically lower than outflow concentrations, and the median values and interquartile ranges for the inflow also were lower than those for the outflow (table 7). No seasonal pattern in $\mathrm{NH}_{3}$ concentrations is apparent (fig. 8A). Output loads of $\mathrm{NH}_{3}$, which constituted 4 percent of the TKN output loads and 1.8 percent of the TN loads exiting the Ellison Park wetland, were consistently greater than the input loads (fig. 8B). The average estimated annual input load of $\mathrm{NH}_{3}$ was 2.59 tons (2 percent of the annual TKN input load and 0.9 percent of the TN load); the average output load was 4.76 tons (table 7). Annual removal efficiencies ranged from -315 to 15.3 percent and averaged -84.0 percent for the study period (fig. 8C). The significant difference (p-value $=$ 0.0001 ) between monthly input and output loads (table 5) indicated that the Ellison Park wetland was a source of $\mathrm{NH}_{3}$. The general downward trend of the monthly removal efficiencies (fig. 8C) indicated that generation of $\mathrm{NH}_{3}$ in the wetland increased through the study period. The increase in $\mathrm{NH}_{3}$ loads was obscured in the TKN data by the large loads of Org-N, which were 2 orders of magnitude larger than the $\mathrm{NH}_{3}$ loads. These results suggest that the increase in $\mathrm{NH}_{3}$ loads was caused by transformation processes within the wetland, such as ammonification and dissimilatory nitrate reduction, and diffusion of $\mathrm{NH}_{3}$ from anaerobic sediments. A net increase in $\mathrm{NH}_{3}$ loads within the wetland can be expected because the rate of ammonification exceeds the rate of nitrification (Kadlec and Knight, 1996). Rates of $\mathrm{NH}_{3}$ production would be expected to be higher under flooded (anaerobic) conditions than under low-water conditions, but coefficients of correlation of $\mathrm{NH}_{3}$ loads and removal efficiencies with monthly mean water levels (table 6) were less than 0.26 and, thus, do not support this interpretation.

\section{Organic Nitrogen}

Organic nitrogen (Org-N) made up 98 percent of the TKN input load; therefore, monthly Org-N loads showed a temporal variation similar to that of TKN during the study period, and the monthly output loads were similar to or slightly less than the monthly input loads. Removal efficiencies for Org-N were slightly higher than those for TKN; annual removal efficiency ranged from 1.5 to 13.4 percent and averaged 8.0 percent for the study period (table 7). The monthly Org-N input loads and output loads differed significantly ( $\mathrm{p}$-value $=0.0006$; table 5). The significant difference for Org-N loads, but not TKN loads, is attributed to the generation of $\mathrm{NH}_{3}$ in the wetland, which offset the slight decrease in Org-N loads.

\section{Nitrate plus Nitrite Nitrogen}

Concentrations of nitrate-plus-nitrite nitrogen $\left(\mathrm{NO}_{\mathrm{x}}\right)$ fell within the interquartile range of 1.2 to $0.73 \mathrm{mg} / \mathrm{L}$ at both sites; the outflow median concentration was slightly less than the inflow median concentration (table 7). A strong seasonal pattern in $\mathrm{NO}_{\mathrm{x}}$ concentrations is evident in fig. $9 \mathrm{~A} ; \mathrm{NO}_{\mathrm{x}}$ concentrations at both monitoring sites increased during late fall and early winter, attained peak values during winter and spring, and decreased through the summer. This pattern could result from denitrification during the summer, but this water-quality improvement did not occur entirely in the wetland because the inflow and outflow concentrations were comparable. The average estimated annual input load of $\mathrm{NO}_{\mathrm{x}}$ was 149 tons and the average output load was 145 tons (table 7). Monthly input loads were similar to monthly output loads (fig. 9), but the difference is significant $(\mathrm{p}$-value $=0.0163)($ table 5$)$. The annual removal efficiencies for $\mathrm{NO}_{\mathrm{x}}$ ranged from -5.0 to 6.8 percent and averaged 2.7 percent (table 7 ) for the study period.

Nitrogen loads entering and leaving the wetland were directly related to discharge (table 6) and were highest during high-flow periods. Coefficients of correlation between discharge and loads of all forms of nitrogen were equal to or greater than 0.90 , except for the output loads of ammonia, whose coefficient of correlation with discharge was 0.88 (table 6). Removal efficiencies for all nitrogen constituents (except $\mathrm{NO}_{\mathrm{X}}$ ), in contrast, appeared not to be correlated with discharge, season, or water level (table 6). The possible exception of $\mathrm{NO}_{\mathrm{x}}$, had a fairly strong association with season (0.67) and water level (0.59). Graphical analyses of nitrogen-removal efficiencies indicate differing seasonal trends: (1) Although $\mathrm{NO}_{\mathrm{x}}$ input loads were generally similar to output loads (fig. 9B), the removal efficiencies (fig. 9C) were low 

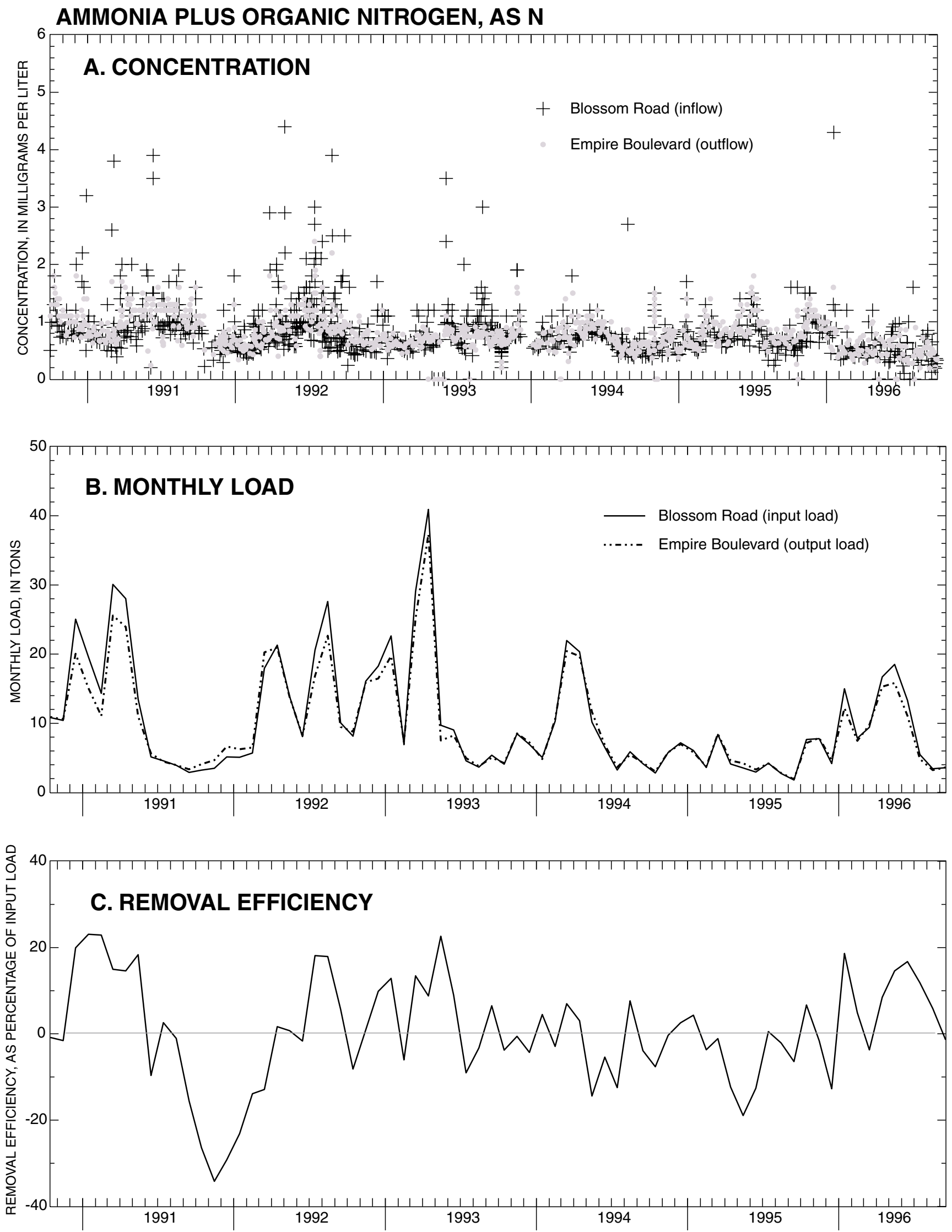

Figure 7. Concentration, monthly load, and removal efficiency of ammonia-plus-organic nitrogen, Ellison Park wetland, Monroe County, N.Y., 1990-96 

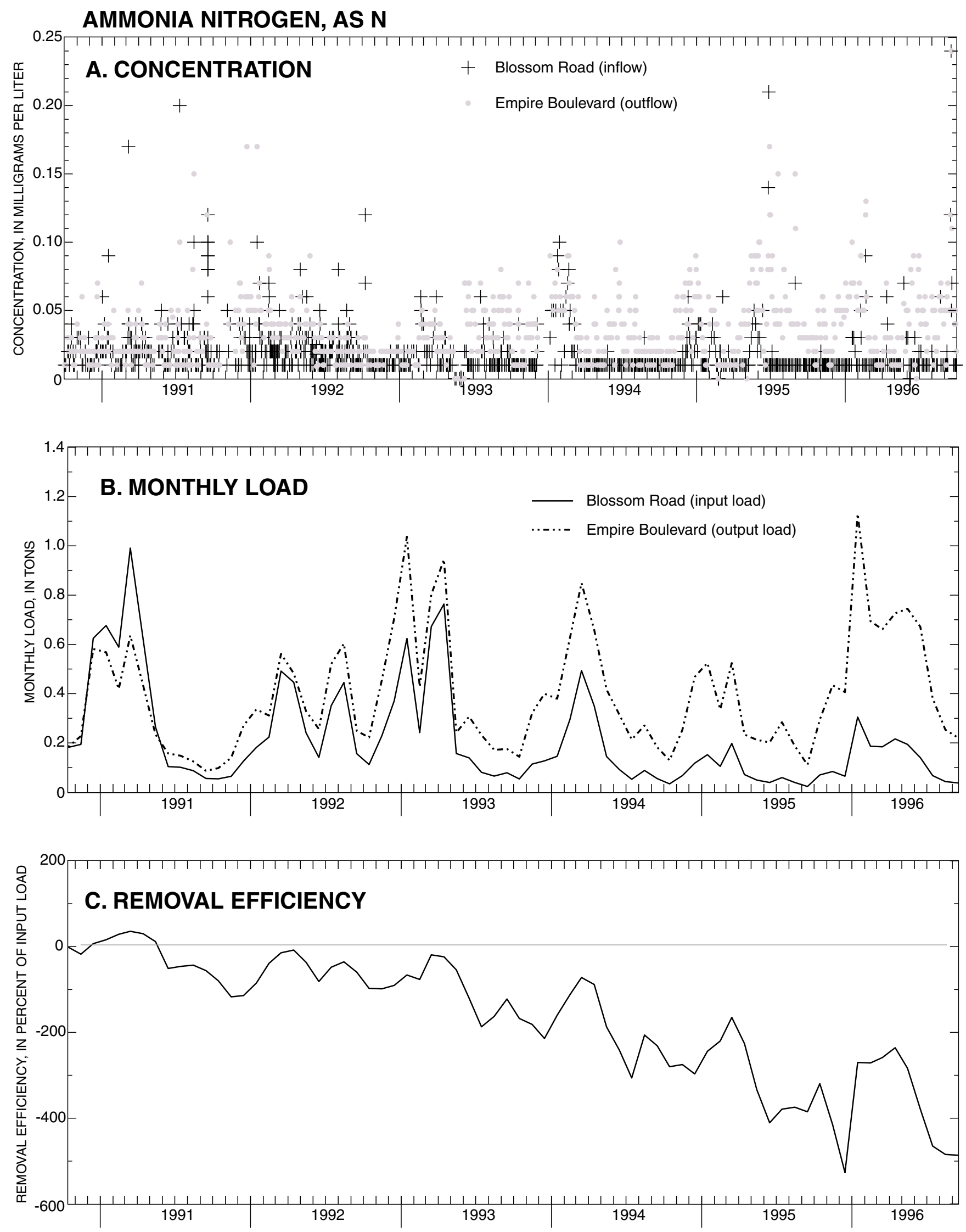

Figure 8. Concentration, monthly load, and wetland's removal efficiency for ammonia nitrogen, Ellison Park wetland, Monroe County, N.Y., 1990-96 

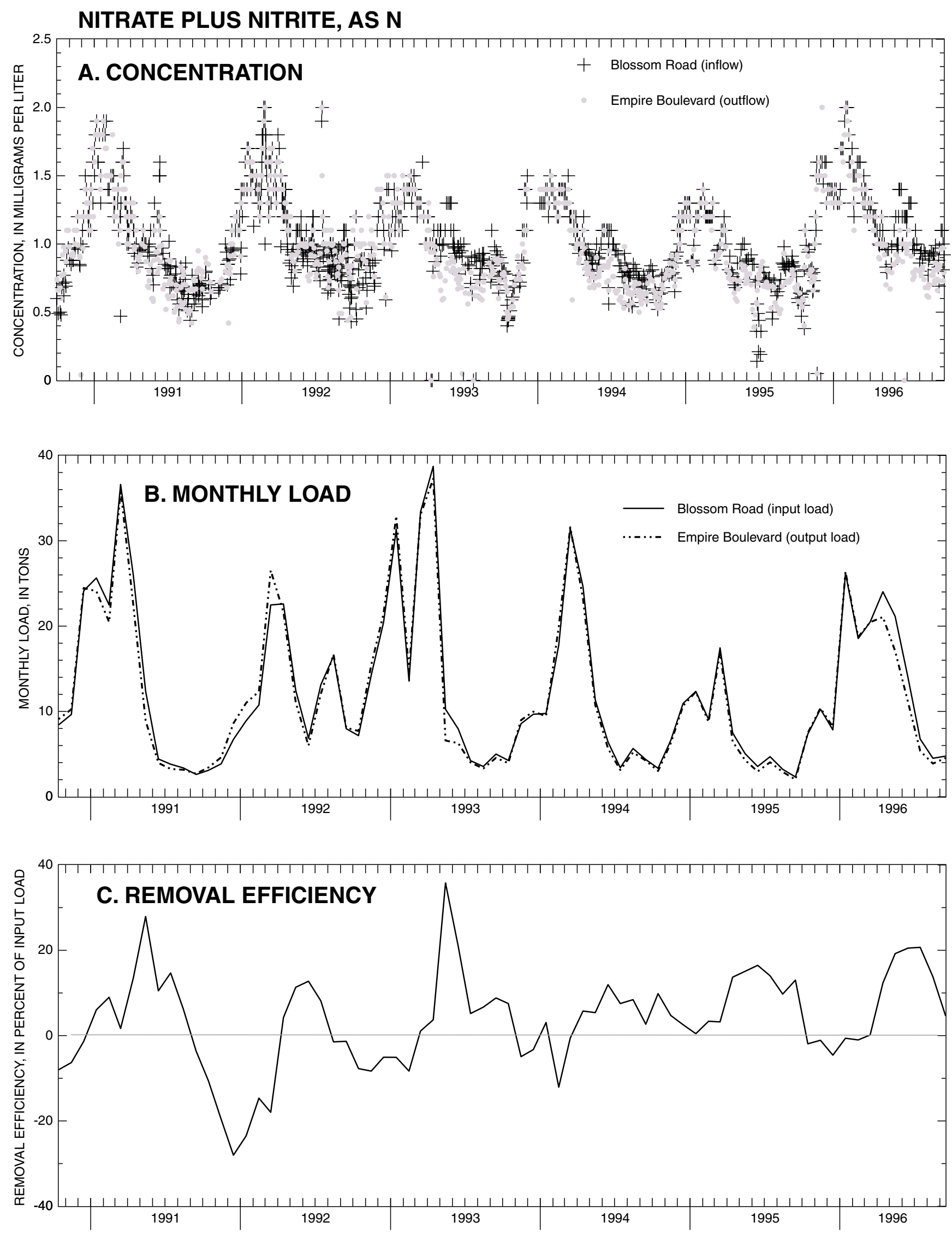

Figure 9. Concentration, monthly load, and wetland's removal efficiency for nitrate-plus-nitrite nitrogen, Ellison Park wetland, Monroe County, N.Y., 1990-96 
or negative during the fall and winter and high during the spring and summer. (2) The exportation of $\mathrm{NH}_{3}$ decreased during late winter and spring (fig. 8C), presumably from the winter decrease in biological activity and an increase in aerobic conditions resulting from low regional water levels. The generation of $\mathrm{NH}_{3}$ increased during the other seasons, presumably as a result of increased biological activity, anaerobic conditions caused by high regional water levels in summer, and plant senescence in fall. TKN input loads were similar to the output loads (fig. 7B), and the removal efficiencies (fig. 7C) fluctuated around zero and formed no noticeable seasonal trend.

An additional observation is that the input loads for $\mathrm{NH}_{3}$ appeared to decrease after 1993 (fig. 8B), while output loads remained about the same. The net result was an increasing trend in the percentage of $\mathrm{NH}_{3}$ that was exported from the wetland. This trend indicates an increase in the rate of transformation of Org- $\mathrm{N}$ to $\mathrm{NH}_{3}$ or in the rate of reduction of $\mathrm{NO}_{\mathrm{x}}$ to $\mathrm{NH}_{3}$, if inputs of $\mathrm{NH}_{3}$ from external sources remained constant. This trend in $\mathrm{NH}_{3}$ export increased noticeably around 1993-94 (figs. 8B, 8C), the period of increased flow into the southeastern part of the southern wetland area after the flow-diversion modifications to the Millrace and, thus, could result from the increased residence time and prolonged contact between stormwaters and wetland biota, and the subsequent increase in the rate of mineralization of organic nitrogen.

\section{Phosphorus}

Surface inflow and its associated suspendedsediment load (primarily clay) is the primary source of phosphorus to a wetland; atmospheric contributions are considered insignificant (Kadlec and Knight, 1996). Phosphorus-storage mechanisms within a wetland include assimilation by plants, microbial utilization, deposition of particulate phosphorus through sedimentation, accretion of biomass in soils, sorbtion to clay and organic particles, and formation of insoluble precipitates with metal cations (iron and aluminum in acidic soils, or calcium and magnesium in alkaline soils) (Kadlec and Knight, 1996; Hickok, 1978; Mitsch and Gosselink, 1986). Phosphorusreleasing processes include oxidation (or decomposition) of organic matter, desorption from clay and organic particles, translocation from soils to above-ground plant tissue, followed by leaching and decay of organic matter, and, in reduced environments, solubilization of iron minerals and subsequent release of phosphorus coprecipitates (Kadlec and Knight, 1996; Gehrels and Mulamoottil, 1989).

\section{Total Phosphorus}

Median concentrations of total phosphorus (TP) at the inflow and outflow were 0.11 and $0.10 \mathrm{mg} / \mathrm{L}$, respectively, and the interquartile ranges for both sites were similar (table 7). Maximum TP concentrations at the inflow were higher, sometimes an order of magnitude higher, than the corresponding concentrations at the outflow, indicating that peak TP concentrations decreased within the wetland. A time plot of TP concentrations (fig. 10A) suggests a slight seasonal pattern of high TP concentrations during the summer and low concentrations during the winter, excepting periods of peak inflows. The average estimated annual input load of TP during the study period was 26.2 tons; the average output load was 19.0 tons (table 7). The monthly input and output loads differed significantly ( $\mathrm{p}$-value $=0.0001$; table 5 ). The wetland was effective in decreasing TP loads; annual TP-removal efficiency ranged from 14.5 to 49.0 percent and averaged 27.6 percent for the study period (table 7). Inflow TP loads were correlated with discharge (Spearman correlation coefficient, 0.87; table 6); they increased in late winter and spring, the period of rapid melting of accumulated snow ("first flush"), and during heavy storms and periods of high runoff during the summer and fall (fig. 10). Unusually large loads of TP (53 percent of the 1992 annual load) entered the wetland during July and August 1992, when three overbank flows occurred, and during March and April 1993, when high flows that included the period-of-record maximum discharge on Irondequoit Creek, carried 58 percent of the 1993 annual TP load into the wetland.

\section{Orthophosphate}

Concentrations of orthophosphate $\left(\mathrm{PO}_{4}\right.$, the dissolved phase of phosphorus) at the inflow were typically lower than at the outflow, as were the median values and interquartile ranges (table 7). A seasonal pattern, although inconsistent, is apparent in the time plot in figure $11 \mathrm{~A}$, which indicates that, during most years, high $\mathrm{PO}_{4}$ concentrations occurred during the summer and fall. The presence of this pattern at both monitoring sites indicates that it cannot result solely from processes within the wetland; superimposed upon this pattern, however, are three summer (1991, 
TOTAL PHOSPHORUS, AS P
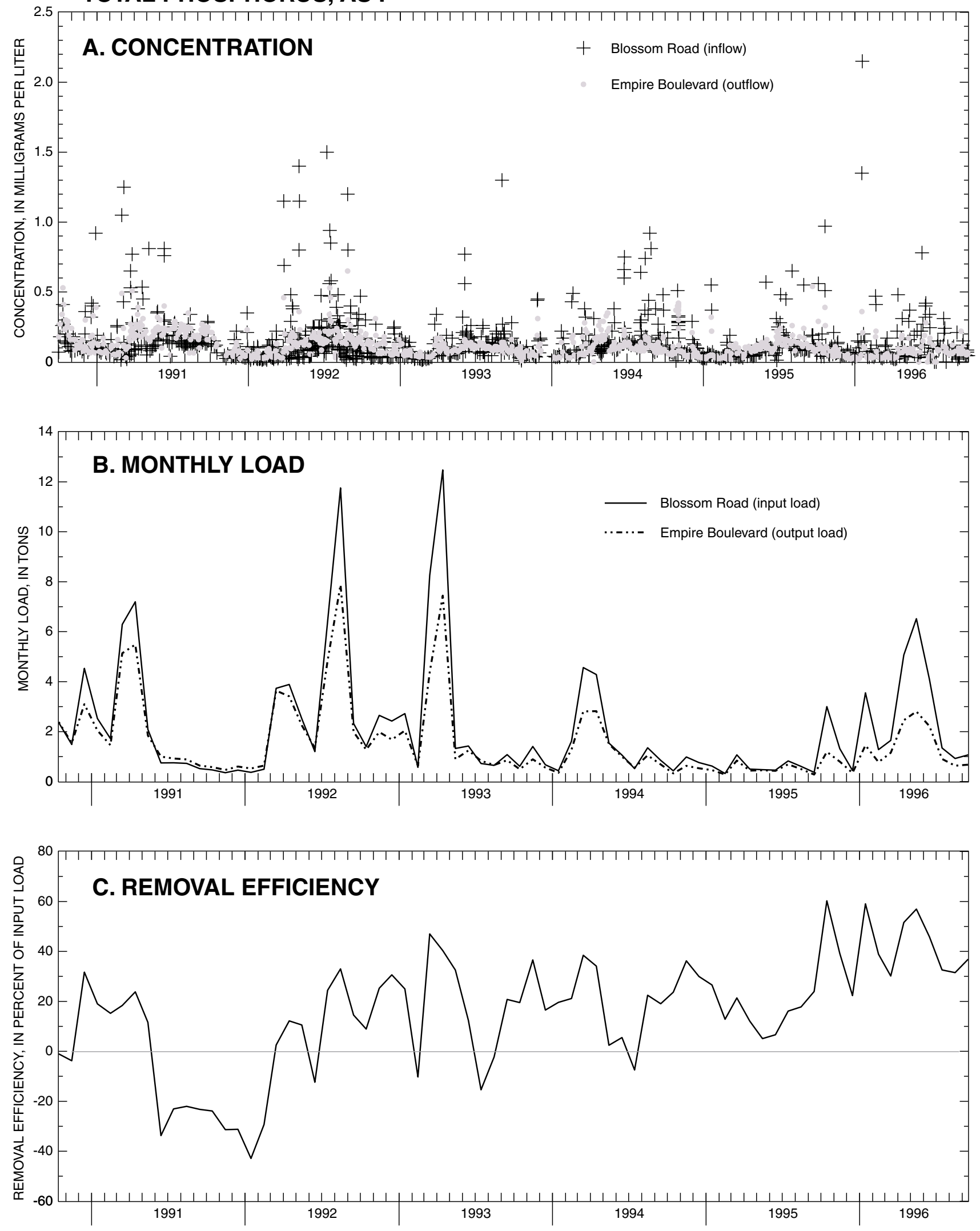

Figure 10. Concentration, monthly load, and wetland's removal efficiency for total phosphorus, Ellison Park wetland, Monroe County, N.Y., 1990-96 
1993, and 1995) periods of elevated $\mathrm{PO}_{4}$

concentrations that occur only at the outlet (fig. 11A) and, therefore, can be attributed to wetland processes. The average estimated annual input load of $\mathrm{PO}_{4}$ was 1.69 tons (6.5 percent of the annual TP input load); the average output load was 2.33 tons (12.3 percent of the TP output load) (table 7). The monthly input and output loads differed significantly (p-value $=0.0001$; table 5). The annual removal efficiency ranged from -10.5 to -67.1 percent and averaged -38.1 percent for the study period (table 7). The generation of $\mathrm{PO}_{4}$ is attributed to the release processes mentioned above. Similar seasonal patterns have been documented by Klopatek (1978) and Kadlec and Knight (1996). The peak loads of $\mathrm{PO}_{4}$ coincided with those for total phosphorus (figs. 10 and 11); that is, peak loads occurred during high-flow periods, but the export of $\mathrm{PO}_{4}$ occurred throughout the study period.

High TP removal efficiency was associated with peak flows, and low removal efficiency was evident during summer low-flow periods (fig. 10C), although the correlation between removal efficiency and inflow loads of total phosphorus was weak (Spearman correlation coefficient, 0.55 ; table 6 ). The removal efficiency for phosphorus appears to have increased around mid-1994 (fig. 11C), probably as a result of the 1994 Millrace modifications that increased flow into the southeastern backwater section of the wetland. Neither water depth nor duration of inundation were related in a consistent manner to phosphorus-removal efficiency when evaluated separately from other factors (table 6). When evaluated in conjunction with inflow loading rates, hovever, they appeared to correlate with phosphorus removal, as evidenced by high removal efficiency during the prolonged periods of inundation in the spring of 1991 and 1993 (figs. 4 and 10C). The correlation between water depth and removal efficiency was probably obscured by the effects of other phosphorus-cycling mechanisms within the wetland.

Phosphorus uptake and retention in temperateclimate marshes, such as the Ellison Park wetland, generally increase during the growing season and decrease during the senescence period; but exceptions have been observed. For example, a 1-year phosphorus-budget study of a Typha marsh in Ontario, Canada, by Gehrels and Mulamoottil (1989) found that seasonal $\mathrm{PO}_{4}$ outputs approximately equaled inputs during winter, spring, and summer but were 60 percent greater than inputs during the fall. Seasonal trends reported by Kadlec and Knight (1996) at five Canadian cattail-monocultural (Typha latifolia) constructed wetlands indicated that (1) large decreases in TP loads resulted from assimilation by biota during the spring growing season and from translocation of nutrients to the rhizomes during the fall; (2) TP removal decreased during the summer, probably as a result of phosphorus-releasing processes (leaching and decomposition of organic matter), which generated more phosphorus than was being retained by phosphorus-assimilation processes; and (3) midwinter decreases in phosphorus removal coincided with a decrease in biological activity. These processes could explain some of the seasonal variations in the TP and $\mathrm{PO}_{4}$ removal efficiencies in the Ellison Park wetland, but the pattern was not consistent from year to year. The summer release of phosphorus by leaching and decomposition of organic matter could be the reason for the non-flow-related decrease in removal efficiency (increase in exportation) of $\mathrm{PO}_{4}$ during the summer of 1992 (fig. 11C).

\section{Suspended Solids}

The primary source of suspended solids in the Irondequoit Creek basin is sediment eroded from stream channels and upland soils. Construction activities and development have disrupted the soil protection afforded by natural vegetation and have increased the amount of sediment-laden runoff. The increase in impervious surface area (buildings, roads, and parking lots) has increased the volume of storm runoff and thereby increased peak discharges for a given rainfall. This, in turn, has altered the hydrologic equilibrium of Irondequoit Creek and probably has aggravated erosion and sediment aggradation. Even if upland erosion and runoff volumes were decreased, channel storage of silt and clay particles from construction and development would be a long-term source of sediment to the wetland (Harbison, 1974). A substantial point source of sediment is a steep bluff composed of fine-grained glacial material about $3 \mathrm{mi}$ upstream from the wetland. Young and Burton (1993) estimated the erosion rate of this bluff and concluded that the volume of sediment derived from it was equal to about 50 percent of the total sediment load delivered to the wetland.

Median concentrations of total suspended solids (TSS) at the inflow and outflow were 139 and $102 \mathrm{mg} / \mathrm{L}$, respectively. Median concentrations of volatile suspended solids (VSS), the organic 

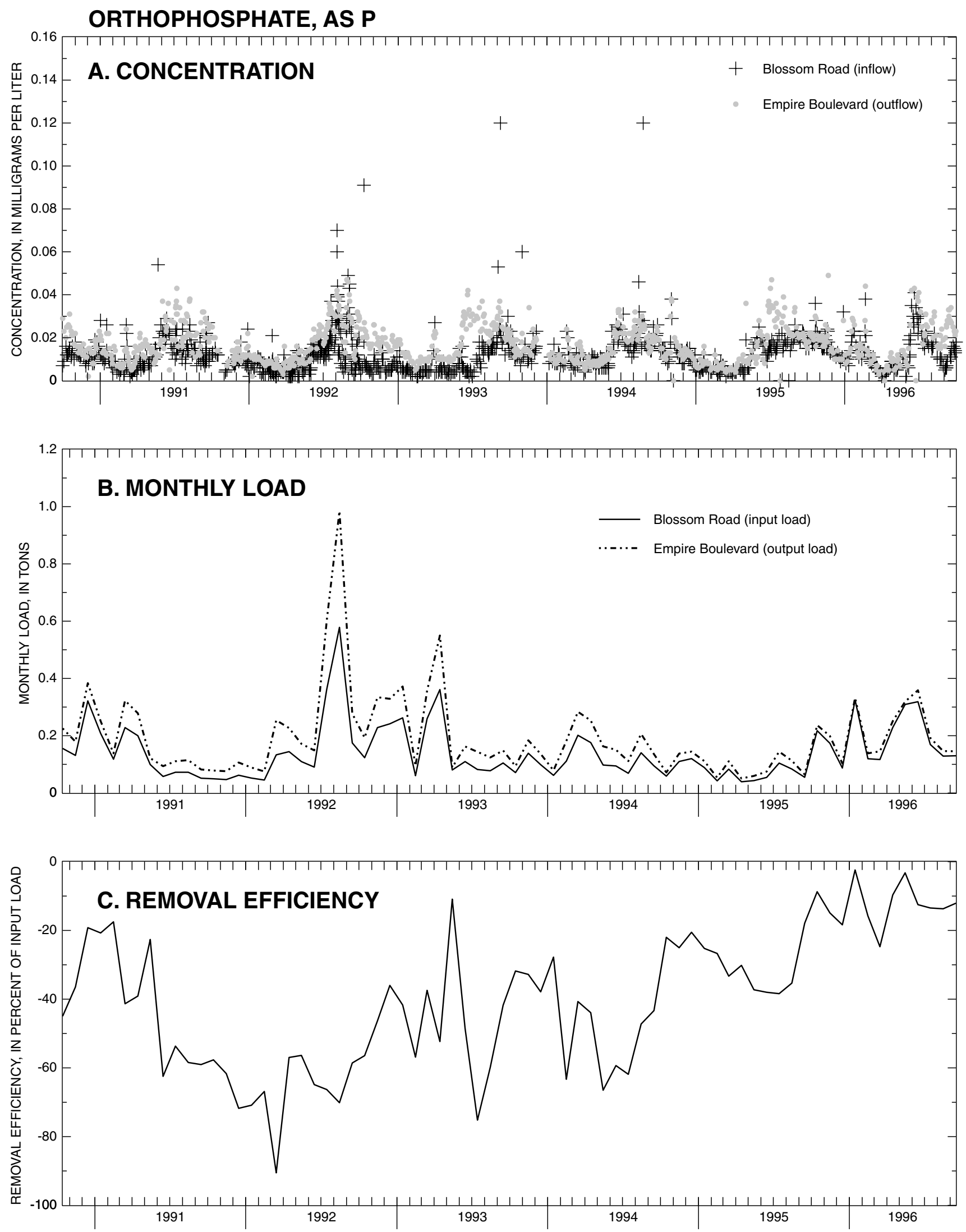

Figure 11. Concentration, monthly load, and wetland's removal efficiency for orthophosphate, Ellison Park wetland, Monroe County, N.Y., 1990-96 
component of TSS, at the inflow and outflow were 21 and $16 \mathrm{mg} / \mathrm{L}$, respectively. The interquartile ranges for both constituents at the inflow exceeded those at the outflow (table 7); thus, the wetland was a sink for suspended solids. The amounts of TSS entering the wetland during the study were large (fig. 12B); the average estimated annual input load was 28,500 tons, and the average output load was 15,200 tons (table 7). This difference, which is statistically significant (pvalue $=0.0001$; table 5), resulted in annual removal efficiencies that ranged from 31.9 to 58.6 percent and averaged 46.7 percent for the study period (table 7 , fig. 12C). Volatile suspended solids constituted 12 to 14 percent of TSS; the average estimated annual input load of VSS was 3,540 tons, and the average output load was 2,080 tons (table 7, fig. 13B). Monthly VSS output loads were significantly lower ( $\mathrm{p}$-value = 0.0001) than input loads (table 5). Annual removal efficiency ranged from 28.1 to 55.4 percent and averaged 41.0 percent for the study period (table 7 , fig. 13C).

Input loads of TSS and VSS were strongly correlated with discharge (Spearman correlation coefficients exceeded 0.93; table 6), and large loads coincided with periods of storm runoff. Although the removal efficiencies for TSS and VSS were not significantly correlated with discharge or season, nor with the duration or depth of wetland inundation (table 6), the removal-efficiency plots for TSS and VSS (figs. 12C and 13C) indicated a strong relation with discharge (fig. 3B). Except for the prolonged dry period of 1991, TSS-removal efficiency fluctuated between about 40 and 60 percent, and the greatest removal efficiencies corresponded to high-discharge periods. The primary factors in the removal of TSS were the low channel gradient and the dense vegetation of the wetland, both of which facilitated the wetland's sedimentation and filtration functions.

A TSS-removal efficiency of 49 percent reported for the Ellison Park wetland for the summer of 1972 by Harbison (1974) closely agrees with that computed from the 1991-96 data (table 7). In contrast, an average annual TSS-removal efficiency of only 12 percent, was measured between Blossom Road and the Narrows for 1980-81 by Kappel and others (1986). This low value probably reflects the removal efficiency for the southern wetland area alone, however.

\section{Chloride and Sulfate}

The primary source of chloride in the Irondequoit Creek basin is the road salts that are applied to highways during the winter (Diment and others, 1974). Chloride is a highly soluble, conservative substance in that it does not precipitate nor enter actively into biological and chemical processes (Kadlec, 1987); thus, its mass remains relatively constant among surface-water inflow and outflow, and wetland storages (Kadlec and Knight, 1996). Median concentrations of chloride at the inflow and outflow sites were 110 and $120 \mathrm{mg} / \mathrm{L}$, respectively, and the interquartile ranges also were similar (table 7). The average estimated annual input load of chloride during the study was 16,800 tons, and the average output load was 17,500 tons (table 7 ). The differences among monthly loads were small but statistically significant ( $p$-value $=0.0001$; table 5 ). The annual removal efficiency ranged from -10.6 to 3.4 percent and averaged -3.9 percent for the study (table 7). Road salt from the land surrounding the wetland downstream from the inflow site probably is the reason why the output loads were slightly greater than the input loads.

Chloride concentrations and loads (fig. 14) were elevated during the winter and low at other times. Peak chloride input and output loads occurred during periods of high discharge (figs. 3 and 14B; Spearman correlation coefficients of 0.91 and 0.92 , respectively, table 6) and reflect the washoff of chloride during the high flows that occurred during the winter and spring snowmelt; chloride loads during summer stormflows were lower. Removal efficiency (fig. 14C) was positive during the high-water periods of 1991 and 1993 (fig. 4), when the high water-surface elevations of Irondequoit Bay and Lake Ontario facilitated the dispersal and detention of flows, and was near-zero or negative during the prolonged low-water periods, when flows entering the wetland in the main channel of Irondequoit Creek had little opportunity for dispersal. Despite these observations, chlorideremoval efficiency was not statistically correlated with discharge, nor with depth or duration of inundation in the wetland (figs. 4 and 14).

Sulfate is an airborne byproduct of fossil-fuel combustion and industrial processes, such as smelting of sulfide ores (Hem, 1989) and, thus, has a widespread distribution and settles to the earth as dryfall or is removed from the air by rain or snow. Sulfate is a soluble salt, and its concentrations and 

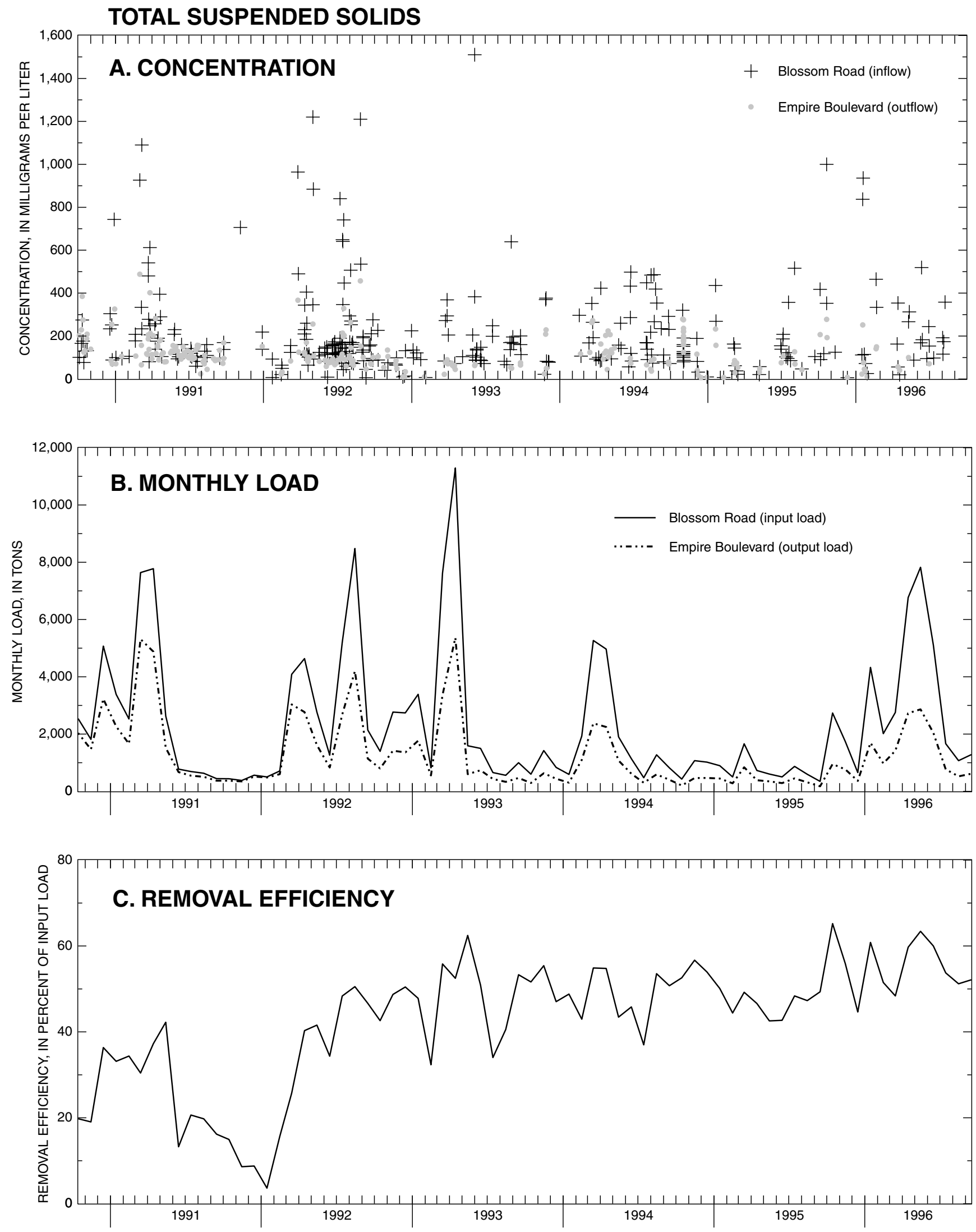

Figure 12. Concentration, monthly load, and wetland's removal efficiency for total suspended solids, Ellison Park wetland, Monroe County, N.Y., 1990-96 
VOLATILE SUSPENDED SOLIDS
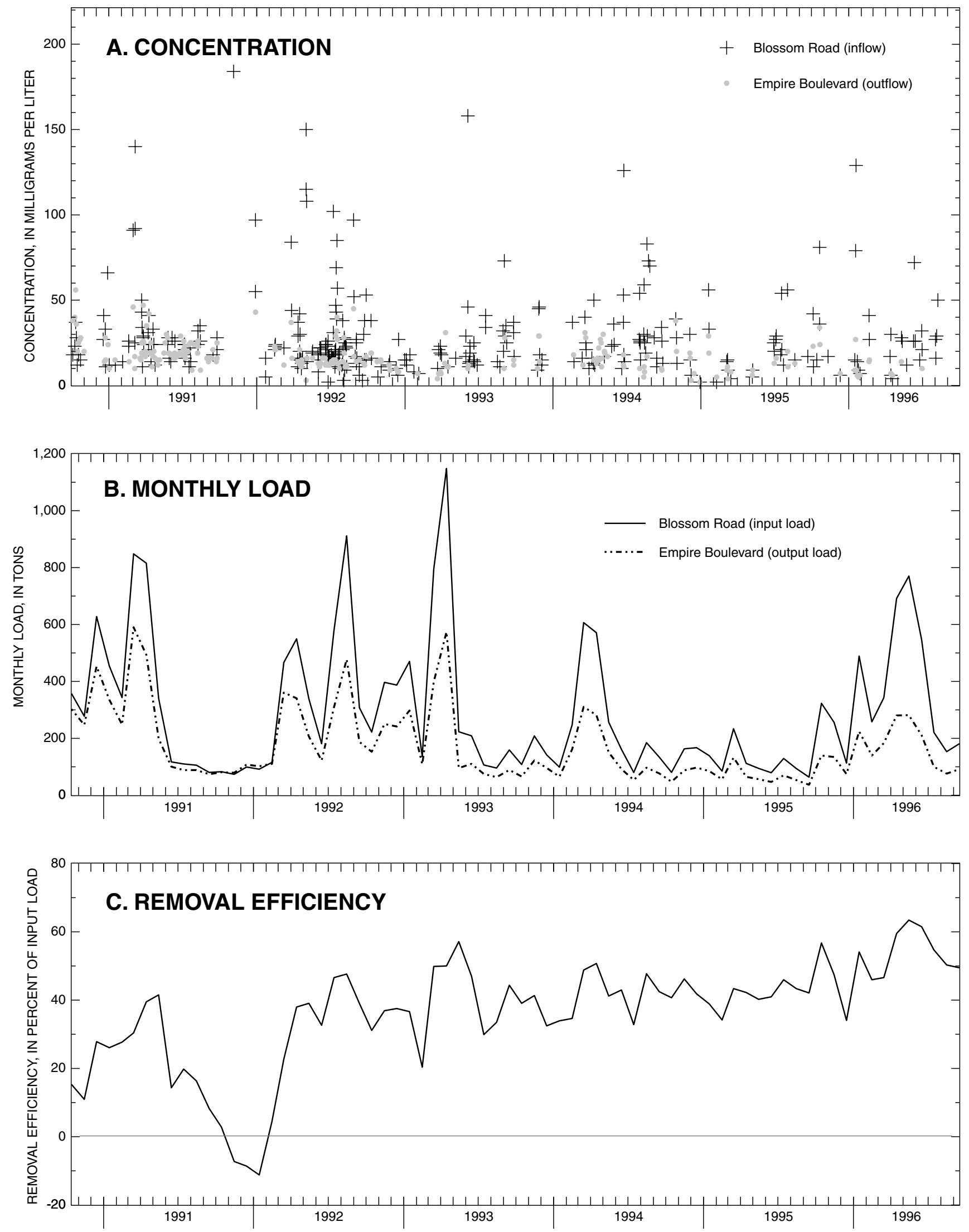

Figure 13. Concentration, monthly load, and wetland's removal efficiency for volatile suspended solids, Ellison Park wetland, Monroe County, N.Y., 1990-96 
loads, like those of chloride, were not greatly affected by the wetland. Median sulfate concentrations were $140 \mathrm{mg} / \mathrm{L}$ at the inflow and outflow sites, and the interquartile ranges differed little between the two sites (table 7). The plot of sulfate concentrations (fig. 15A) indicates seasonally high concentrations from midsummer through autumn of most years and low concentrations from late winter through spring. The average estimated annual input and output loads of sulfate were 16,000 and 15,700 tons, respectively (table 7), but the monthly output loads were significantly different from (slightly less than) the input loads ( $p$-value $=0.0024$; table 5 ). This decrease within the wetland could result from sulfate reduction under anaerobic conditions. The annual removal efficiency ranged from -2.4 to 7.4 percent and averaged 2.0 percent for the study period (table 7 ). The temporal pattern of input and output loads and removal efficiency (fig. 15) was similar to that for chloride (fig. 14).

\section{Trace Metals}

Water samples were collected from Irondequoit Creek during stormflows, and less frequently during low-flow periods, and were analyzed for four trace metals-zinc, lead, copper, and cadmium (appendix 1). The range of inflow and outflow concentrations of zinc, lead, and copper are shown in boxplots in figure 16; cadmium concentrations were usually below the analytical detection limit and were excluded. Concentrations at the inflow were generally greater than at the outflow. The median concentrations of these metals in Irondequoit Creek were compared with (1) average concentrations found in rivers worldwide (Kadlec and Knight, 1996) and in the United States (Hem, 1989; Durum and others, 1971), and (2) a summary statistic derived from the nationwide data collected during the 1980-81 NURP studies (U.S. Environmental Protection Agency, 1983). Of the 13 metals for which urban-runoff samples from NURP study sites were analyzed, copper, lead and zinc were detected most frequently-in at least 91 percent of the samples, and in some samples at concentrations that exceeded U.S. Environmental Protection Agency water-quality standards (U.S. Environmental Protection Agency, 1983). The mean concentration of a given constituent during a specific stormflow (or event mean concentration, EMC) at a NURP site was computed as the total constituent mass divided by the total runoff volume (U.S. Environmental Protection Agency, 1983) and was used to normalize the data for differences in precipitation and runoff among the study sites. The median EMC for each constituent from each NURP site was computed, and the median value of the ranked medians from all NURP sites was used as a nationwide summary statistic for each constituent.

\section{Zinc}

Zinc, an essential micronutrient for plants and animals, is naturally occurring but becomes widely distributed in the environment through its many uses. It is used in dry-cell batteries, building materials, and alloys such as brass and bronze (Windholz, 1983); galvanized steel, paint pigment, and rubber (Hem, 1989). Median zinc concentrations in streams worldwide are reported to be between 5 and $45 \mu \mathrm{g} / \mathrm{L}$ (Hem, 1989), and the average concentration is estimated to be $10 \mu \mathrm{g} / \mathrm{L}$ (Kadlec and Knight, 1996). A median value of $20 \mu \mathrm{g} / \mathrm{L}$ has been reported for U.S. streams in 1970 by Durum and others (1971). The NURP median EMC concentration of zinc was $160 \mu \mathrm{g} / \mathrm{L}$ (U.S. Environmental Protection Agency, 1983), but this value represents zinc concentrations in urban stormwater, which do not reflect average conditions. Median concentrations of zinc in Irondequoit Creek at the wetland inflow and outflow during this study were $40 \mu \mathrm{g} / \mathrm{L}$ (fig. 16), but the outflow concentrations were significantly lower than the inflow concentrations ( $p$-value $=0.0078$; table 8). The maximum zinc concentrations at the inflow and outflow were $370 \mu \mathrm{g} / \mathrm{L}$ and $150 \mu \mathrm{g} / \mathrm{L}$, respectively. The elevated zinc concentrations in the Irondequoit Creek basin are most likely a result of urbanization but also could be due partly to the dissociation of zinc sulfide from dolomite, which underlies part of the basin and is also within the overlying glacial deposits and local soils (Kappel and others, 1986). Removal of zinc by wetlands results from adsorption, sedimentation, ion exchange, formation of insoluble compounds such as zinc sulfide, which then precipitate, and through bioaccumulation, primarily in plant roots (Hem, 1989; Kadlec and Knight, 1996).

\section{Lead}

Lead has low solubility, adsorbs readily to organic and inorganic-sediment surfaces (Hem, 1989), and forms insoluble salts with sulfides, carbonates, sulfates, and chlorophosphates (Kadlec and Knight, 1996). Manmade sources of lead include pipes, 

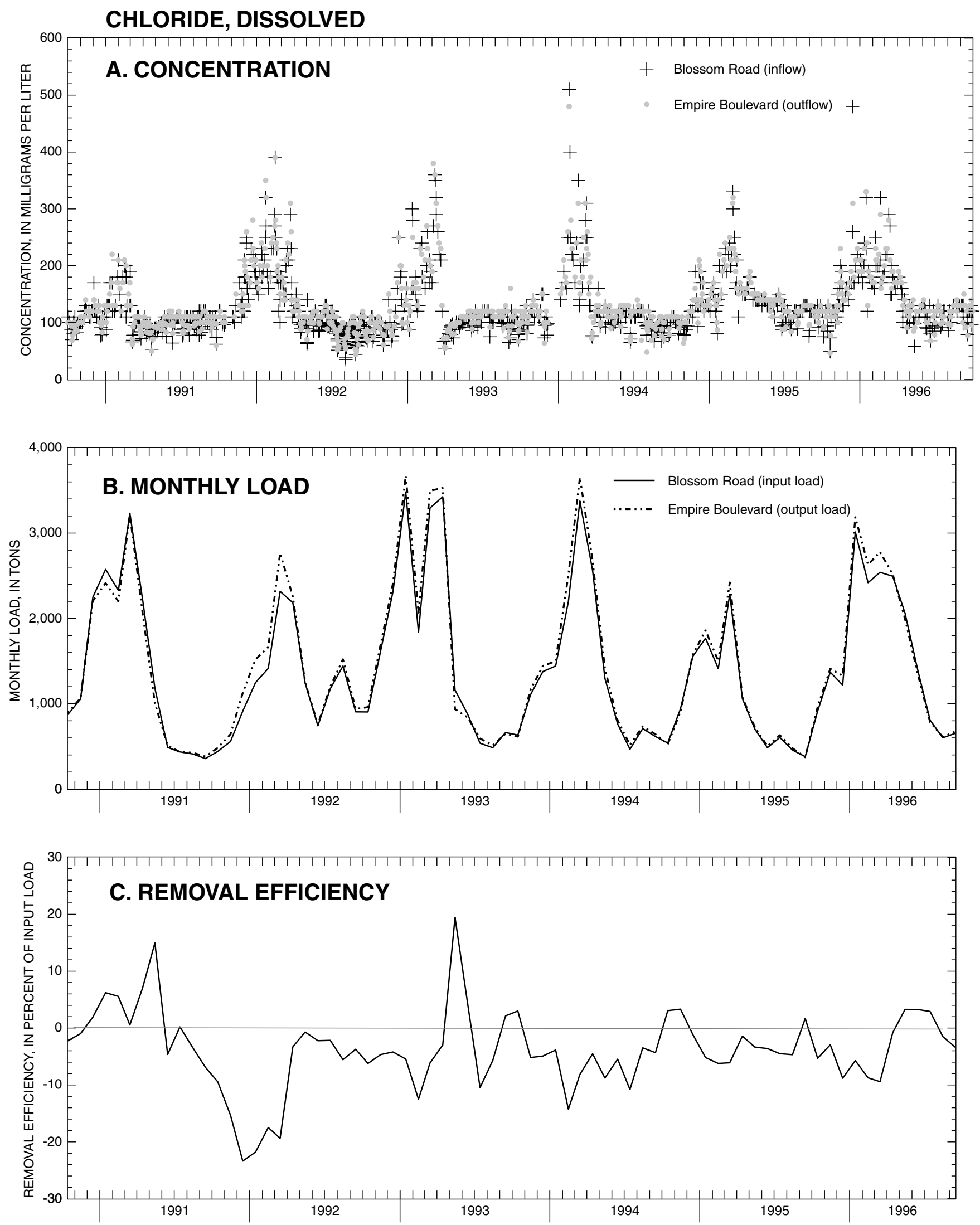

Figure 14. Concentration, monthly load, and wetland's removal efficiency for chloride, Ellison Park wetland, Monroe County, N.Y., 1990-96 

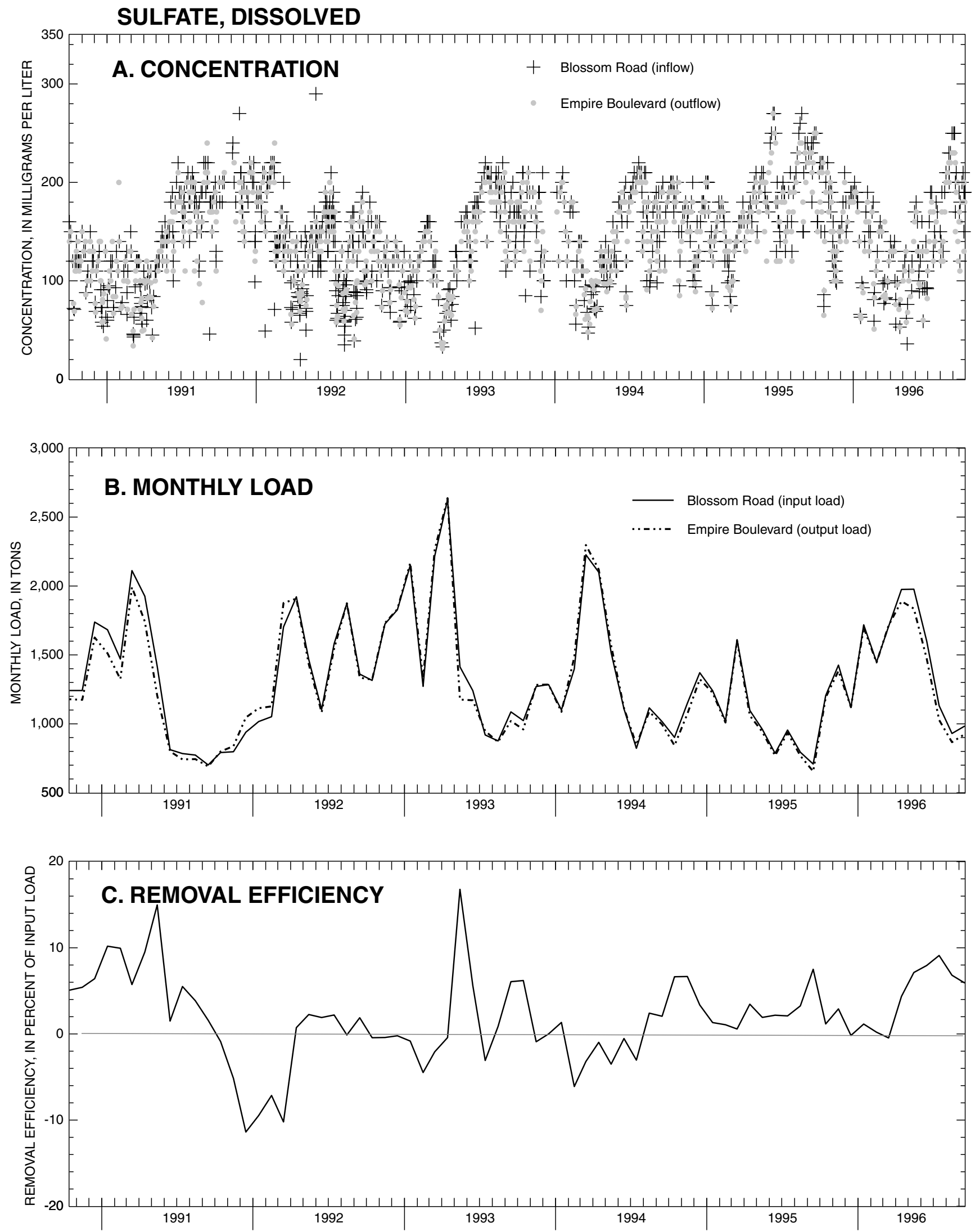

Figure 15. Concentration, monthly load, and wetland's removal efficiency for sulfate, Ellison Park wetland, Monroe County, N.Y., 1990-96 

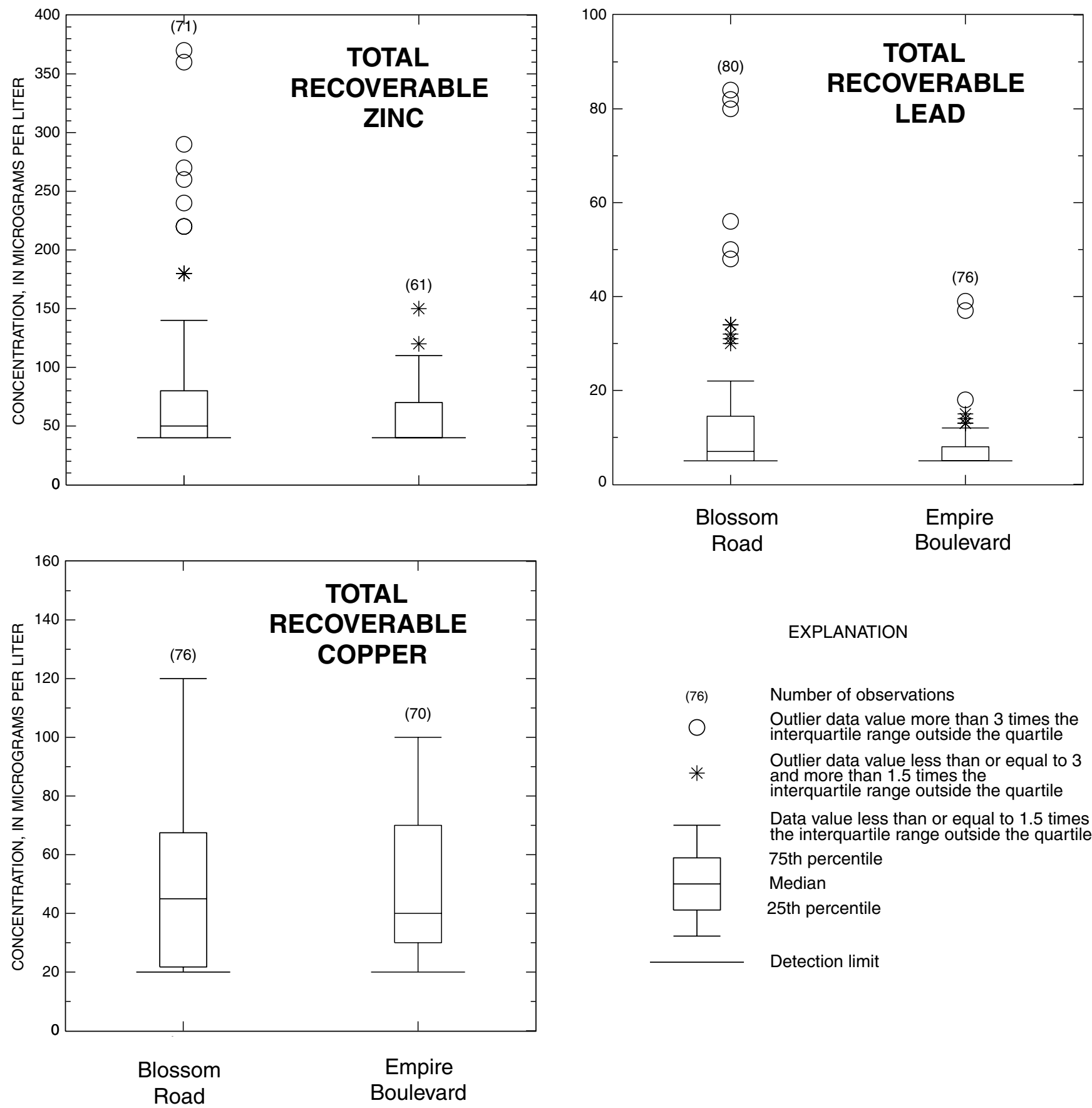

EXPLANATION

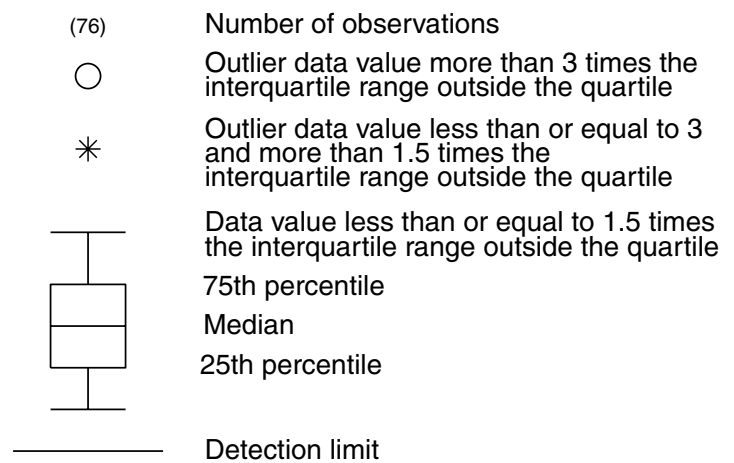

Figure 16. Concentrations of selected trace metals in stormwater samples from Irondequoit Creek above Blossom Road and at Empire Boulevard, Monroe County, N.Y., 1990-96

plastics, ceramics, paints, batteries, smelting of ores, and combustion of coal and leaded gasoline (Hem, 1989; Windholz, 1983). Lead concentration in the world's rivers averages about $0.2 \mu \mathrm{g} / \mathrm{L}$ (Kadlec and Knight, 1996), and that in U.S. streams ranges between 1 and $10 \mu \mathrm{g} / \mathrm{L}$ (Hem, 1989; Durum and others, 1971). The NURP median EMC concentration of lead in urban stormwater was $144 \mu \mathrm{g} / \mathrm{L}$ (U.S. Environmental Protection Agency, 1983). Median concentrations of lead in Irondequoit Creek during this study were $7 \mu \mathrm{g} / \mathrm{L}$ at the inflow and $5 \mu \mathrm{g} / \mathrm{L}$ at the outflow (fig. 16), a significant decrease (p-value = 
Table 8. Selected statistics on trace-metal concentrations in Irondequoit Creek above Blossom Road (wetland inlet) and at Empire Boulevard (wetland outlet), Monroe County, N.Y., 1990-96

[mg/L, milligrams per liter; <, less than. Dash indicates no conclusion can be stated. Locations are shown in fig. 2.]

\begin{tabular}{|c|c|c|c|c|c|c|c|c|c|c|}
\hline \multirow[b]{3}{*}{ Metal } & \multicolumn{4}{|c|}{ Number of observations } & \multirow{3}{*}{$\begin{array}{c}\text { Censoring } \\
\text { limit(s), } \\
\text { mg/L }\end{array}$} & \multirow{2}{*}{\multicolumn{2}{|c|}{$\begin{array}{c}\text { Median } \\
\text { concentration, } \mathrm{mg} / \mathrm{L}\end{array}$}} & \multirow{3}{*}{$\begin{array}{c}p \text {-value } \\
\text { Wilcoxon } \\
\text { Rank } \\
\text { Sum test }^{2}\end{array}$} & \multirow{3}{*}{$\begin{array}{c}\text { Signifi- } \\
\text { cant } \\
\text { differ- } \\
\text { ence }\end{array}$} & \multirow{3}{*}{$\begin{array}{c}\text { Point of } \\
\text { greater } \\
\text { concen- } \\
\text { tration }\end{array}$} \\
\hline & \multicolumn{2}{|r|}{ Inflow } & \multicolumn{2}{|c|}{ Outflow } & & & & & & \\
\hline & Total & Censored & Total & Censored & & Inflow & Outflow & & & \\
\hline Zinc & 783 & 220 & 659 & 192 & 40 & 40 & 40 & 0.0078 & yes & inflow \\
\hline Lead & 79 & 21 & 76 & 25 & 2,5 & 7 & 5 & .0096 & yes & inflow \\
\hline Copper & 77 & 7 & 73 & 6 & $10,20,50$ & 50 & 40 & .89 & no & -- \\
\hline Cadmium & 82 & 62 & 78 & 65 & 1,5 & $<1.0$ & $<1.0$ & .0265 & yes & inflow \\
\hline
\end{tabular}

${ }^{1}$ Censoring limit varies with equipment used for analysis.

${ }^{2}$ Test of significant difference between median inflow and outflow concentrations.

0.0096; table 8). The maximum lead concentrations at the inflow and outflow were $84 \mu \mathrm{g} / \mathrm{L}$ and $39 \mu \mathrm{g} / \mathrm{L}$, respectively. Lead removal in wetlands results from the formation of insoluble compounds and subsequent sedimentation; lead also can become biomagnified in aquatic biota (Kadlec and Knight, 1996).

\section{Copper}

Copper is an essential micronutrient for plants and animals and enters the environment from its use in water pipes and plumbing fixtures; it also is used in algicides and pesticides (Hem, 1989), in alloys such as bronze and brass, and in electrical conductors, ammunition, and wood preservatives (Windholz, 1983). Another source, particularly in urban settings, is the abrasion of vehicle brake pads (WoodwardClyde Consultants, 1994; 1997). Of the 13 metals detected in NURP urban-runoff samples, copper was the most frequently detected (U.S. Environmental Protection Agency, 1983). The average copper concentration in the world's rivers is about $2 \mu \mathrm{g} / \mathrm{L}$ (Kadlec and Knight, 1996), and that in U.S. streams is about $10 \mu \mathrm{g} / \mathrm{L}$ (Hem, 1989; Durum and others, 1971). The NURP median EMC concentration was $34 \mu \mathrm{g} / \mathrm{L}$ (U.S. Environmental Protection Agency, 1983). Median concentrations at the wetland inflow and outflow during this study were $50 \mu \mathrm{g} / \mathrm{L}$ and $40 \mu \mathrm{g} / \mathrm{L}$, respectively (fig. 16), but this apparent decrease was not statistically significant $(\alpha=0.10$; table 8$)$. The maximum copper concentrations at the inflow and outflow were $120 \mu \mathrm{g} / \mathrm{L}$ and $100 \mu \mathrm{g} / \mathrm{L}$, respectively. The data indicate a decrease in concentrations from 1990 through 1996 (appendix 1). Wetlands can decrease copper loads through adsorption on mineral and organic surfaces, through the formation of complexes with hydroxides, sulfides, and carbonates, and through bioaccumulation in plant tissues (Kadlec and Knight, 1996).

\section{Cadmium}

Cadmium is a naturally occurring element that enters the environment through industrial uses, which include electroplating and photography; it also is used in paint pigment, printing ink, and plastics, and as a stabilizer in PVC products, in electrical batteries, and in fluorescent and video tubes (Hem, 1989; Windholz, 1983). The average concentration of cadmium in surface waters worldwide is about $0.07 \mu \mathrm{g} / \mathrm{L}$ (Kadlec and Knight, 1996) and about $1 \mu \mathrm{g} / \mathrm{L}$ in U.S. streams (Hem, 1989; Durum and others, 1971). Cadmium concentrations in 76 and 83 percent of the samples collected at the wetland inflow and outflow, respectively, were below the analytical detection limit of $1 \mu \mathrm{g} / \mathrm{L}$. Nonetheless, the outflow concentrations, when detected, were significantly lower than the inflow concentrations ( $\mathrm{p}$-value $=0.0265$; table 8). Maximum cadmium concentrations at the inflow and outflow during this study were $3 \mu \mathrm{g} / \mathrm{L}$ and $4 \mu \mathrm{g} / \mathrm{L}$, respectively. The removal efficiency for cadmium in most wetlands is greater than 75 percent. Removal is achieved through adsorption on organic particles and the formation, and subsequent sedimentation, of sulfides (Kadlec and Knight, 1996). 


\section{Water Temperature}

Surface-water temperature increased by passage through the wetland, especially during the summer (fig. 17A), through the slow movement of water, the shallow conditions, and the absence of shade. Winter water temperatures at the outflow site were similar to those at the inflow site; daily mean temperatures at the outflow usually differed from those at the inflow by less than $0.5^{\circ} \mathrm{C}$ (fig. 17B), except in late spring and summer, when daily mean outflow temperatures were generally 1 to $2{ }^{\circ} \mathrm{C}$ higher than the inflow temperatures (fig. 17B). This difference narrowed during periods of storm runoff, as shown by the temperature record and storm hydrograph (fig. 17C) for June 18-28, 1996. The diurnal temperature pattern at the inflow site was not greatly affected by the runoff, except on June 19 and 20 , when the runoff shifted the time of the peak temperatures. At the outflow site, the runoff lowered the water temperature to as low as the inflow temperature or lower. This cooling was enhanced by cloudy conditions on June 18-20, when less than 20 percent of possible sunshine was recorded (Northeast Regional Climate Center, 1996). Soon after the passage of the stormwater, temperatures at both sites increased, and the difference in the temperature records increased to prestorm values.

\section{Characteristics of Wetland Sediments}

The composition of channel-bottom material varies within the Ellison Park wetland according to the flow velocity. The predominant bed material in the main channel (Irondequoit Creek), in which high flow velocities occur, is sand, but the predominant bed materials in the open, backwater areas where velocities are slow are silt and clay. The four bottomsediment samples collected for chemical analyses (fig. 2) were taken from backwater areas; more than 82 percent of the particles were silt sized and smaller (less than $4 \mathrm{~mm}$ in diameter). The high percentage of fine-grained mineral particles reflects the wetland's high removal efficiency for suspended solids that accumulate in these depositional environments. The sediment samples were 3.4 to 5.0 percent total organic carbon by weight and contained 0.13 percent phosphorus by weight. The relatively low concentrations of organic carbon in these samples reflects the low rate of biomass accumulation from small submergent aquatic macrophytes (such as
Myriophyllum sp. and Ceratophyllum demersum). The organic content in the cattail-vegetated (Typha glauca) areas of the wetland is expected to be substantially greater than that indicated by these results.

Results of the sediment analyses are presented in appendix 4. The high percentage of silt and clay in the sediment, and the presence of organic matter, are conducive to adsorption of metals (Hem, 1989) and organic compounds (Smith and others, 1988). Metals found in elevated concentrations (greater than 200 ppm; see table 9) included barium, manganese, strontium, and zinc; these concentrations were within the range expected for water draining an urbanized watershed, however (E.C. Callender, U.S. Geological Survey, written commun., 1996). The elevated concentrations of these and other trace elements, including chromium, copper, lead, and vanadium, could be indicative of the effectiveness of the wetland's removal processes, as substantiated by the decrease in surface-water concentrations of lead and zinc between the inflow- and outflow-sampling sites, or the attainment of the wetland's maximum retention capacity. Another major mechanism for removal of metals is the uptake and possible bioaccumulation by plants, especially in roots and rhizomes, as discussed in the following section.

Some polycyclic aromatic hydrocarbons (PAH's), including chrysene, fluoranthene, phenanthrene, and pyrene, also were found in high concentrations in the wetland sediments, as were five persistent organochlorine pesticides (chlordane, dieldrin, DDT and its metabolic-degradation products, DDD and DDE) and polychlorinated biphenyls (PCB's) (table 9). The presence, and the magnitude of concentrations, of these compounds are fairly typical of a depositional environment in a highly urbanized watershed, and many of the pesticide and PCB concentrations are comparable to or lower than those measured in 14 studies in the United States during the 1970's and 1980's, as reported by Smith and others (1988, p. 33). Concentrations of cadmium, copper, mercury, silver, and all detected PAH's were noticeably higher in the sample from the northern (downstream) part of the wetland than in the three samples from the southern part, possibly as a result of current or past chemical inputs from the adjacent drainage area, but no definite conclusions can be drawn from these sparse data.

Wetland sediments can act as a sink for chemicals that (1) precipitate out of solution as 

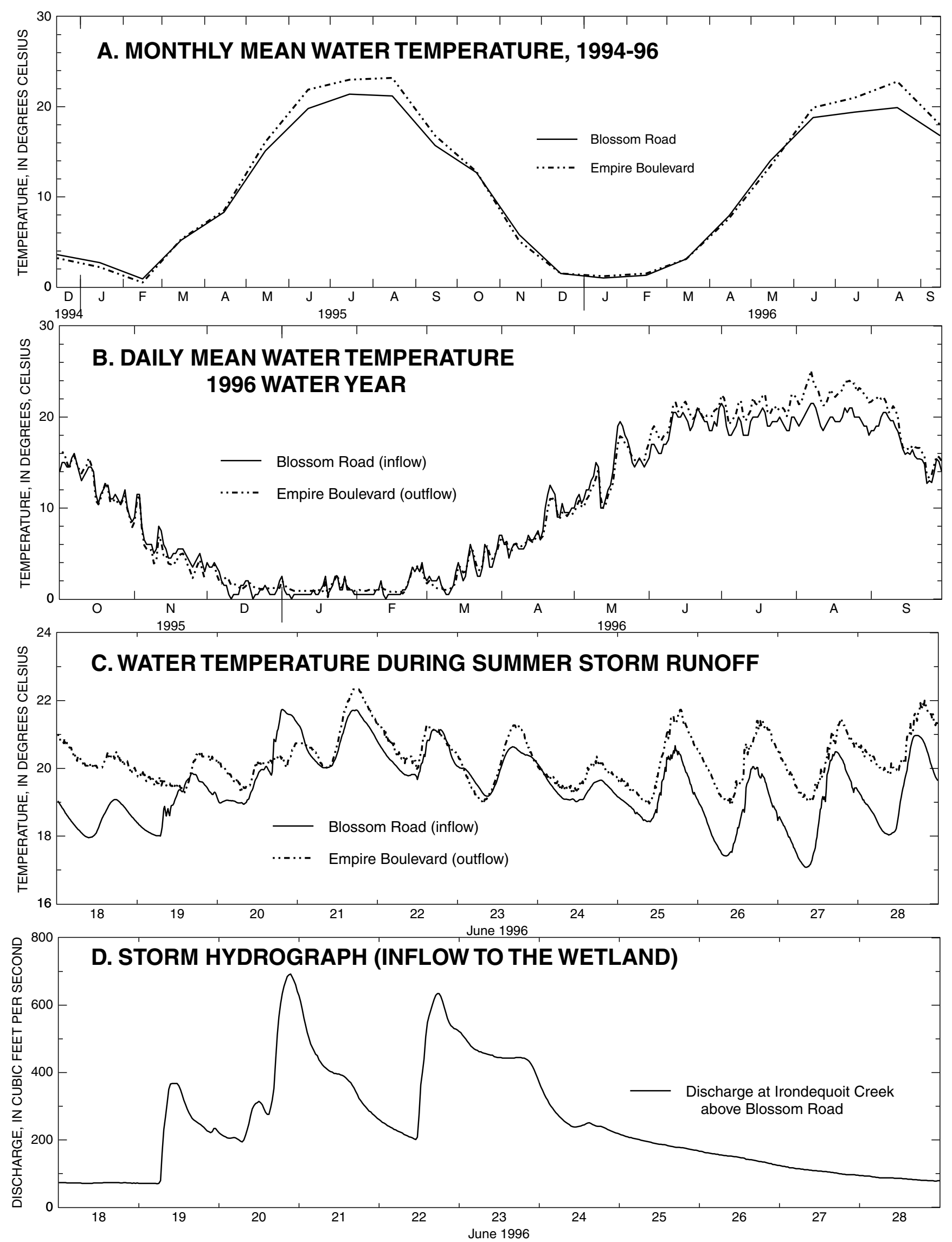

Figure 17. Water temperatures at Irondequoit Creek above

Blossom Road and at Empire Boulevard, Monroe County, N.Y.: A. Monthly mean water temperature, 1994-96. B. Daily mean water temperature, 1996 water year. C. Water temperature and D. hydrograph during storm runoff period, June 18-28, 1996 
insoluble salts, (2) are in particulate form, or (3) adsorb to mineral and organic particles (Kadlec and Knight, 1996). The storage potential of wetland soils for sorptive chemicals becomes limited, however, when the soil's capacity is reached (Mitsch and Gosselink, 1986; Gehrels and Mulamoottil, 1989; Kadlec and Knight, 1996). Thus, the only mechanism for increasing the capacity for long-term storage of chemicals is the accretion and subsequent burial of organic matter and the insoluble, particulate, and adsorbed chemicals

\section{Characteristics of Wetland Vegetation (Typha glauca)}

Vegetation plays an important role in the wetland's effectiveness in improving water quality.
Plants provide filtration, nutrient assimilation and translocation, heavy-metal uptake, and surfaces for microbial growth and their subsequent utilization of nutrients (Kadlec and Knight, 1996). The Ellison Park wetland is an ideal environment for cattails, Typha glauca, which cover more than 60 percent of it. The cattails are extremely tall (more than $10 \mathrm{ft}$ at the peak of the growing season) and have a high density, a large biomass, and a considerable capacity for taking up and utilizing nutrients during the growing season.

\section{Density and Biomass}

Characteristics of Typha glauca in the southern and northern parts of the wetland, including density, height, percentage of land surface covered, and biomass, for the two flora studies conducted during 1991 and 1996 are presented in table 10. About 63 percent, or 265 acres, of the wetland's land surface

Table 9. Concentrations of selected chemicals in sediment of Ellison Park wetland, Monroe County, N.Y., October $1994^{1}$

[Concentrations are average values from four samples. Percentages are by dry weight.]

\begin{tabular}{|c|c|c|c|c|c|}
\hline Elements & $\begin{array}{c}\text { Percent or } \\
\text { concentration }\end{array}$ & Elements & Concentration & Organic compounds & Concentration \\
\hline \multicolumn{2}{|l|}{ Percent by weight } & \multicolumn{2}{|c|}{ Parts per million (cont.) } & \multicolumn{2}{|l|}{ Parts per billion } \\
\hline Aluminum & 4.9 & Gallium & 12 & Chlordane & 22 \\
\hline Calcium & 6.0 & Lanthanum & 24 & DDD & 4.8 \\
\hline Carbon, organic & 4.0 & Lead & 65 & DDE & 7.5 \\
\hline Carbon, inorganic & 1.7 & Lithium & 27 & DDT & .8 \\
\hline Iron & 2.6 & Manganese & 710 & Dieldrin & 2.2 \\
\hline Magnesium & 1.3 & Mercury & .19 & PCB & 40 \\
\hline Phosphorus & .13 & Neodymium & 24 & Benzo $a$ anthracene & 850 \\
\hline Potassium & 1.6 & Nickel & 20 & Benzo $b$ fluoranthene & 1,000 \\
\hline Sodium & 1.2 & Niobium & 11 & Benzo $k$ fluoranthene & 1,040 \\
\hline Sulfur & .43 & Scandium & 8 & Benzo $a$ pyrene & 800 \\
\hline Titanium & .26 & Selenium & .7 & Bis(2-ethyhexyl) phthalate & 600 \\
\hline \multicolumn{2}{|l|}{ Parts per million } & Silver & 1.2 & Chrysene & 1,100 \\
\hline Antimony & 0.4 & Strontium & 400 & Fluoranthene & 2,080 \\
\hline Arsenic & 4.6 & Thorium & 6.2 & Phenanthrene & 920 \\
\hline Barium & 460 & Uranium & 1.6 & Pyrene & 1720 \\
\hline Beryllium & 1 & Vanadium & 48 & & \\
\hline Cadmium & 1.8 & Yttrium & 19 & & \\
\hline Cerium & 43 & Ytterbium & 2 & & \\
\hline Chromium & 49 & Zinc & 230 & & \\
\hline Cobalt & 11 & & & & \\
\hline Copper & 54 & & & & \\
\hline
\end{tabular}

1 Values for other trace elements, organochlorine compounds, and polycyclic aromatic hydrocarbons that were not found in concentrations above the analytical detection limit are tabulated in Coon (1997). 
was covered by cattails. Cattail density ranged from 31 to 38 shoots per $1-\mathrm{m}^{2}\left(3.3-\mathrm{ft}^{2}\right)$ plot and averaged 34 shoots $/ \mathrm{m}^{2}$. These shoots averaged about $280 \mathrm{~cm}$ $(9.2 \mathrm{ft})$ in height, and those in the northern part of the wetland averaged more than $300 \mathrm{~cm}(9.8 \mathrm{ft})$ in 1991 and attained maximum heights of $350 \mathrm{~cm}(11.5 \mathrm{ft})$. Cattail density and height varied with soil wetness; dry areas along streambanks and deep-water areas, where water depth exceeded about $40 \mathrm{~cm}$ (15 in.), yielded lower productivity than areas where the water level was between a few centimeters and about $30 \mathrm{~cm}$ (12 in.) above the top of the cattail mat.

The average weight of an individual shoot was $76 \mathrm{~g}$; the maximum average was $90 \mathrm{~g}$ for plants in the northern part of the wetland during 1996. These long, dense shoots yielded a large biomass that averaged $2,608 \mathrm{~g} / \mathrm{m}^{2}$ above ground (46 percent of the total biomass) and $3,025 \mathrm{~g} / \mathrm{m}^{2}$ below ground. Maximum values were found in the northern wetland area during 1996. Above- and below-ground biomass exceeded most values reported by other researchers; reported measurements of peak above-ground biomass in Typha glauca range from $1,281 \mathrm{~g} / \mathrm{m}^{2}$ in an Iowa marsh (Van der Valk and Davis, 1978) to $1,361 \mathrm{~g} / \mathrm{m}^{2}$ in a central New York site (Bernard and Fitz, 1979) to 2,320 g/m in a Minnesota marsh (Andrews and Pratt, 1978). Peak shoot biomass of other Typha species range from 1,118 to $2,338 \mathrm{~g} / \mathrm{m}^{2}$ (Whigham and others, 1978; Mason and Bryant, 1975; McNaughton, 1966; Van der Valk and Davis, 1978; Boyd and Hess, 1970; Boyd, 1971; Bray, Lawrence, and Pearson, 1959). Reported measurements of peak below-ground biomass in Typha glauca range from $1,450 \mathrm{~g} / \mathrm{m}^{2}$ in an Iowa marsh (Van der Valk and Davis, 1978) to $2,960 \mathrm{~g} / \mathrm{m}^{2}$ (Bray, 1960 ) and $3,100 \mathrm{~g} / \mathrm{m}^{2}$ (Andrews and Pratt, 1978) in two Minnesota sites. Peak below-ground biomass of other Typha species range from 2,646 to $5,053 \mathrm{~g} / \mathrm{m}^{2}$ (Whigham and others, 1978; McNaughton, 1966). Reported values for total biomass, which is infrequently measured, range from $3,405 \mathrm{~g} / \mathrm{m}^{2}$ in Oregon and 3,982 $\mathrm{g} / \mathrm{m}^{2}$ in Texas (McNaughton, 1966) to 4,230 and $4,720 \mathrm{~g} / \mathrm{m}^{2}$ in Minnesota (Andrews and Pratt, 1978; Bray, 1960). Total biomass measured in the Ellison Park wetland ranged from $4,801 \mathrm{~g} / \mathrm{m}^{2}$ in the southern area in 1991 to $7,085 \mathrm{~g} / \mathrm{m}^{2}$ in the northern area in 1996 and averaged $5,633 \mathrm{~g} / \mathrm{m}^{2}$ over the two study periods (table 10).

The values for all these characteristics, except cattail height in the northern area and below-ground biomass in the southern area, were lower in 1991 than in 1996, perhaps as a result of differences in sampling date, or chance variation in sampling resulting from differences in water depth, temperature, or other environmental factors. Seasonal variations in cattail biomass have been documented by many of the studies referenced above. Annual variation in wetland-plant biomass also has been reported: for example, a 37percent difference in above-ground biomass of Phragmites australis, another emergent wetland plant, was found in Norfolk, England over a 3-yr period (Boar, 1996). Therefore, the mean values for both sampling periods (1991 and 1996) are considered reliable representations of the average values for cattails over the entire wetland (table 10).

\section{Nutrients and Trace Metals}

Results of the chemical analyses of cattail tissue are presented in table 11; the values represent aboveand below-ground tissues collected from both parts of

Table 10. Characteristics of Typha glauca in Ellison Park wetland, Monroe County, N.Y., 1991 and 1996

$\left[\mathrm{g} / \mathrm{m}^{2}\right.$, grams per square meter. Values are averages of samples collected along the specified transect. Data from Bernard and Seischab $(1991,1997)$.]

\begin{tabular}{|c|c|c|c|c|c|}
\hline \multirow[b]{3}{*}{ Characteristic } & \multicolumn{4}{|c|}{ Transect location within wetland } & \multirow{3}{*}{$\begin{array}{c}\text { Overall } \\
\text { mean }\end{array}$} \\
\hline & \multicolumn{2}{|c|}{1991} & \multicolumn{2}{|c|}{1996} & \\
\hline & Southern part & Northern part & Southern part & Northern part & \\
\hline Number of 1-square-meter plots & 31 & 26 & 31 & 20 & 27 \\
\hline Number of shoots per square meter & 32 & 31 & 35 & 38 & 34 \\
\hline Height, centimeters & 212 & 318 & 290 & 297 & 279 \\
\hline Percentage of land surface covered & 68 & 79 & 88 & 97 & 83 \\
\hline Weight per shoot, grams & 65 & 76 & 72 & 90 & 76 \\
\hline Above-ground biomass, $\mathrm{g} / \mathrm{m}^{2}$ & 2094 & 2368 & 2505 & 3466 & 2608 \\
\hline Below-ground biomass, $\mathrm{g} / \mathrm{m}^{2}$ & 2707 & 3291 & 2484 & 3619 & 3025 \\
\hline Total biomass, $\mathrm{g} / \mathrm{m}^{2}$ & 4801 & 5659 & 4989 & 7085 & 5633 \\
\hline
\end{tabular}


the wetland during the two study periods (1991 and 1996). No striking differences are evident between the above-ground tissue data for 1991 and those for 1996, except possibly for aluminum and manganese concentrations, both of which were more than twice as great in 1991 as in 1996. The 1991 below-ground tissue data for most constituents also were similar to the 1996 data, except for boron concentrations, which were almost three times higher in 1991 than in 1996. Concentrations of sodium and lead were not measured in 1996.

Above-ground cattail tissues assimilated an average of 2.4 and 0.3 percent of their dry weight in nitrogen and phosphorus, respectively. Of the major macronutrients, nitrogen and potassium were found in higher concentrations in above-ground tissues ( 2.4 and 1.5 percent by dry weight, respectively) than in belowground tissues; calcium and magnesium were found in higher concentrations in below-ground tissues. Aboveground concentrations of phosphorus, as well as molybdenum and manganese, were similar to those below ground; concentrations of all other chemicals were considerably higher in below-ground tissues.
Concentrations of manganese (417 ppm) and sodium $(3,600 \mathrm{ppm})$ in above-ground tissues were exceptionally high, as were those of aluminum $(1,540$ $\mathrm{ppm})$, iron $(15,400 \mathrm{ppm})$, manganese (433 ppm), and sodium $(10,000 \mathrm{ppm})$ in below-ground tissues. These concentrations exceeded those typically found in a wide range of aquatic plants in natural wetlands (Hutchinson, 1975; Vitosh and others, 1973). The chemical composition of the Ellison Park cattails was generally within the range observed at two other cattail-study sites - a natural marsh in South Carolina (Boyd, 1970) and a constructed wetland in New York that receives landfill leachate (Bouldin and others, 1993). An exception was sodium, which was found in higher concentrations in the Ellison Park cattails than in those at the other sites, presumably as a result of winter road-salt application in the basin. Also, as in other studies, the highest concentration of micronutrients was found in below-ground tissues.

\section{Chemical Standing Stocks}

The standing stock of an element in an ecosystem is defined as the total mass of that element,

Table 11. Average dry-weight percentage or concentration of selected elements in above- and belowground biomass of Typha glauca in Ellison Park wetland, Monroe County, N.Y., 1991 and 1996

[\%, percent by weight; ppm, parts per million. Dash indicates no data.]

\begin{tabular}{|c|c|c|c|c|c|c|}
\hline \multirow[b]{2}{*}{ Element } & \multicolumn{3}{|c|}{ Above-ground biomass } & \multicolumn{3}{|c|}{ Below-ground biomass } \\
\hline & 1991 & 1996 & Mean & 1991 & 1996 & Mean \\
\hline Nitrogen, $\%$ & 2.6 & 2.3 & 2.4 & 0.8 & 0.8 & 0.8 \\
\hline Phosphorus, \% & .3 & .3 & .3 & .2 & .2 & .2 \\
\hline Potassium, $\%$ & 1.4 & 1.7 & 1.5 & .4 & .6 & .5 \\
\hline Calcium, \% & 1.0 & .8 & .9 & 1.3 & 1.4 & 1.4 \\
\hline Magnesium, \% & .2 & .18 & .19 & .5 & .5 & .5 \\
\hline Copper, ppm & 5.3 & 3.9 & 4.6 & 15.6 & 13.9 & 14.7 \\
\hline Nickel, ppm & 1.6 & 1.1 & 1.4 & 9.6 & 11.7 & 10.6 \\
\hline Chromium, ppm & 1.4 & .12 & .8 & 6.0 & 5.2 & 5.6 \\
\hline Cobalt, ppm & .1 & .1 & .1 & 6 & .6 & 6 \\
\hline Molybdenum, ppm & .4 & .5 & .5 & 6 & .5 & .5 \\
\hline Zinc, ppm & 17.5 & 13.5 & 15.5 & 59.8 & 48.5 & 54.1 \\
\hline Aluminum, ppm & 17.3 & 6.0 & 11.6 & 1,880 & 1,200 & 1,540 \\
\hline Iron, ppm & 67.4 & 56.6 & 62.0 & 18,000 & 12,800 & 15,400 \\
\hline Boron, ppm & 12.1 & 7.0 & 9.6 & 132 & 46.5 & 89.2 \\
\hline Manganese, ppm & 598 & 236 & 417 & 458 & 408 & 433 \\
\hline Sodium, ppm & 3,600 & -- & 3,600 & 10,000 & -- & 10,000 \\
\hline Lead, ppm & 6 & -- & 6 & 18.9 & -- & 18.9 \\
\hline
\end{tabular}


computed as the product of the element's

concentration and the total biomass of the ecosystem.

The total standing stocks of elements in above- and below-ground cattail tissues for 1991 and 1996, and the percentage of the total in the above-ground tissues, are presented in table 12. The above-ground tissue samples contained more than half of the total standing stocks of only three elements-nitrogen (73 percent), phosphorus (54 percent), and potassium (72 percent). Nitrogen had the largest above-ground standing stocks of any constituent measured, averaging almost $60 \mathrm{~g} / \mathrm{m}^{2}$; phosphorus, had just over $6 \mathrm{~g} / \mathrm{m}^{2}$ in aboveground tissues. Other elements with large aboveground standing stocks included potassium $\left(37 \mathrm{~g} / \mathrm{m}^{2}\right)$, calcium $\left(23 \mathrm{~g} / \mathrm{m}^{2}\right)$, and sodium $\left(7 \mathrm{~g} / \mathrm{m}^{2}\right)$. The other elements, especially the metals, tended to be concentrated in below-ground tissues; 98 percent of standing stocks of lead and more than 99 percent of standing stocks of iron and aluminum were found in below-ground tissues. Other elements with large below-ground standing stocks were iron $\left(41 \mathrm{~g} / \mathrm{m}^{2}\right)$, calcium $\left(37 \mathrm{~g} / \mathrm{m}^{2}\right)$, sodium $\left(24 \mathrm{~g} / \mathrm{m}^{2}\right)$, magnesium $\left(14 \mathrm{~g} / \mathrm{m}^{2}\right)$, and aluminum $\left(4 \mathrm{~g} / \mathrm{m}^{2}\right)$.

\section{Water-Quality-Improvement Function of Ellison Park Wetland}

A wetland's ability to improve water quality by the retention or removal of sediment and nutrients carried in stormwater, and the mechanisms by which this is achieved, are of special interest to waterresources managers, especially if the wetland is in an urban setting. The Ellison Park wetland is smaller than would be desired for a constructed wetland designed to effectively treat the volume and quality of stormwater that passes through it (the wetland covers 0.5 percent of Irondequoit Creek's drainage area). The water-quality, sediment, and biomass data obtained in this study indicate that the wetland provides effective stormwater treatment despite its small size and poor dispersal of all but the largest stormflows. The loads of particulate constituents (total phosphorus and suspended solids) and of constituents that form precipitates or that adsorb to, or chemically bind with, fine-grained sediment particles or organic matter (metals and organic chemicals) were significantly decreased by sedimentation and vegetative filtration. The loads of other constituents, such as organic

Table 12. Average standing stocks of selected elements in above- and below-ground biomass of Typha glauca in Ellison Park wetland, Monroe County, N.Y., 1991 and 1996

$\left[\mathrm{g} / \mathrm{m}^{2}\right.$, grams per square meter; $\mathrm{mg} / \mathrm{m}^{2}$, milligrams per square meter. Dash indicates no data.]

\begin{tabular}{|c|c|c|c|c|c|c|c|c|}
\hline \multirow[b]{2}{*}{ Element } & \multicolumn{3}{|c|}{ Above-ground standing stock } & \multicolumn{3}{|c|}{ Below-ground standing stock } & \multirow{2}{*}{$\begin{array}{c}\text { Total mean } \\
\text { standing } \\
\text { stock }\end{array}$} & \multirow{2}{*}{$\begin{array}{c}\text { Percent } \\
\text { standing stock } \\
\text { above ground }\end{array}$} \\
\hline & 1991 & 1996 & Mean & 1991 & 1996 & Mean & & \\
\hline Nitrogen, $g / \mathrm{m}^{2}$ & 50.1 & 68.1 & 59.1 & 19.1 & 23.8 & 21.4 & 80.5 & 73 \\
\hline Phosphorus, g/m $\mathrm{m}^{2}$ & 4.8 & 8.3 & 6.5 & 5.2 & 6.0 & 5.6 & 12.1 & 54 \\
\hline Potassium, $\mathrm{g} / \mathrm{m}^{2}$ & 27.0 & 47.8 & 37.4 & 9.6 & 19.6 & 14.6 & 52.0 & 72 \\
\hline Calcium, $\mathrm{g} / \mathrm{m}^{2}$ & 19.2 & 26.5 & 22.8 & 30.4 & 43.6 & 37.0 & 59.8 & 38 \\
\hline Magnesium, $\mathrm{g} / \mathrm{m}^{2}$ & 3.8 & 5.4 & 4.6 & 10.8 & 16.4 & 13.6 & 18.2 & 25 \\
\hline Iron, $\mathrm{g} / \mathrm{m}^{2}$ & .13 & .17 & .15 & 43.4 & 39.4 & 41.4 & 41.6 & .4 \\
\hline Manganese, $\mathrm{g} / \mathrm{m}^{2}$ & 1.2 & .7 & .9 & 1.0 & 1.2 & 1.1 & 2.0 & 45 \\
\hline Sodium, $\mathrm{g} / \mathrm{m}^{2}$ & 6.9 & -- & 6.9 & 24.1 & -- & 24.1 & 31.0 & 22 \\
\hline Copper, mg/m² & 10.2 & 11.8 & 11.0 & 37.6 & 41.8 & 39.7 & 50.7 & 22 \\
\hline Nickel, mg/m² & 3.0 & 3.0 & 3.0 & 23.1 & 35.4 & 29.2 & 32.2 & 9 \\
\hline Chromium, mg/m² & 2.6 & .3 & 1.4 & 14.4 & 15.0 & 14.7 & 16.1 & 9 \\
\hline Cobalt, $\mathrm{mg} / \mathrm{m}^{2}$ & .09 & .20 & .14 & 1.4 & 1.8 & 1.2 & 1.3 & 11 \\
\hline Molybdenum, mg/m² & .8 & 1.5 & 1.1 & 1.4 & 1.5 & 1.4 & 2.5 & 44 \\
\hline Zinc, $\mathrm{mg} / \mathrm{m}^{2}$ & 33.6 & 40.2 & 36.9 & 144 & 149 & 146 & 183 & 20 \\
\hline Aluminum, mg/m² & 33.3 & 17.5 & 25.4 & 4,524 & 3,662 & 4,093 & 4,118 & .6 \\
\hline Boron, $\mathrm{mg} / \mathrm{m}^{2}$ & 23.2 & 20.4 & 21.8 & 320 & 140 & 230 & 252 & 9 \\
\hline Lead, $\mathrm{mg} / \mathrm{m}^{2}$ & 1.1 & -- & 1.1 & 45.6 & -- & 45.6 & 46.7 & 2 \\
\hline
\end{tabular}


nitrogen, nitrate plus nitrite, and sulfate, were moderately decreased, although the long-term (6-year) removal efficiencies were low, less than 8 percent.

The input-output relations and the chemicalremoval efficiencies found in this study were determined mainly by: (1) inflow loading rates, (2) storage or release mechanisms in the sediments, and (3) accretion and burial of organic detritus. The chemical loads and removal efficiencies for most constituents were directly related to stream discharge; that is, high flows produced large chemical loads and resulted in high removal efficiencies for constituents that were affected by the wetland, and low flows generally resulted in low removal efficiencies (relative to a given constituent).

Many of the chemicals, such as the metals, for which the cattail-tissue samples were analyzed, were more abundant in below-ground tissue than in aboveground tissue, but even nitrogen, phosphorus, and potassium, whose above-ground standing stocks were large during the growing season, might have been translocated below ground prior to senescence and stored during the winter. Generally T. glauca retains less than half of the summer standing stocks of these nutrients at the time of senescence (Bernard and Fitz, 1979); the remainder may be released into the water, and large releases of elements during fall and winter have been documented in some studies (Mason and Bryant, 1975; Gehrels and Mulamoottil, 1989). The chemical concentrations of some constituents showed seasonal patterns in this study, but most of the patterns were evident in the inflow data as well as the outflow data and, therefore, cannot be attributed to wetland processes alone. The chemical load data also do not indicate a seasonal release of nutrients during senescence, except possibly for nitrate plus nitrite, but do indicate that large amounts of chemicals are stored in the sediments and below-ground biomass. In addition to this long-term retention of nutrients and trace elements, the above-ground biomass and the microbial community provide a seasonal storage of chemicals. This seasonal retention is not reflected by the surface-water output loads of most constituents, however, and indicates that most of the seasonal nutrient needs of flora and microbes are not met by surface-water inputs, but through internal cycling of chemicals from the sediments and detritus, and that vegetative assimilation generally did not measurably decrease the nutrient loads in surface water passing through the wetland. A similar conclusion was reached by Johnston (1991), who reviewed the results of many wetland studies and noted that, with the exception of floating plants, vegetative uptake often is less important in sediment and nutrient retention in wetlands than physical and microbial processes. In the Ellison Park wetland, physical processes are the primary mechanisms for the decrease in surface-water chemical loads, but the effect of microbial processes, although considered substantial, were not studied directly and, except for the generation of ammonia nitrogen, had no identifiable effect on surface-water chemical loads.

The two removal processes that can be considered ultimate sinks for nutrients retained in a Typha sp. wetland are denitrification and the permanent burial of nutrients in sediment (Prentki and others, 1978). The effectiveness of burial is dependent on the availability of buried nutrients in root-zone soils, and the susceptibility of these nutrients to reuptake by wetland plants and subsequent release back into surface waters. If the depth of burial is sufficient to inhibit the translocation of nutrients in this manner, accretion and burial of sediment and dead but undecomposed plant tissues will be an effective nutrient trap and would provide a long-term removal mechanism for some chemicals. The magnitude of this removal mechanism in the Ellison Park wetland has not been documented, however.

\section{Progress Toward Water-Quality Improvement of Irondequoit Bay}

Improvement of the ecological and recreational status of Irondequoit Bay through control of nutrient loads entering the bay have been management objectives of Monroe County since the 1970's. Progress toward these objectives has been monitored by (1) evaluation of the bay's trophic status through periodic sampling of summer phytoplankton chlorophyll_a concentrations and calculation of biologically available phosphorus concentrations in the bay, and (2) estimation of constituent loads entering the bay in surface-runoff.

\section{Trophic Status}

Two limnological measures of lake fertility are concentrations of phytoplankton chlorophyll, a measure of algal growth present, and phosphorus, a productivity-limiting nutrient. Chlorophyll_a 
concentrations have been measured in Irondequoit Bay since 1971 (MCEHL, written comm., 1997). Biweekly water samples are collected at a measuring site at the deepest point in the bay between May 1 and October 31 at about 3 -ft intervals through about $20 \mathrm{ft}$ of depth in the epilimnion. Concentrations of chlorophyll_a within the water column are averaged for a given day, and the mean of these daily values is used as the summer mean chlorophyll concentration. The potential, or biologically available, phosphorus concentration in the bay is computed from the annual total-phosphorus load and surface-water discharge to the system, and the bay's mean depth and surface area (Vollenweider, 1976). The chlorophyll_a and potential-phosphorus concentrations in the bay indicated the eutrophic conditions during the 1970's, when effluent from sewage-treatment plants was discharged into Irondequoit Creek (fig. 18). These concentrations have decreased in response to the cessation of effluent discharges in 1977 and, possibly, to erosion- and stormwater-control measures implemented by Monroe County to decrease chemical loads from nonpoint sources in the basin. The trophic state of Irondequoit Bay has improved during the last 20 years, but this improvement has not reached target levels nor returned the bay to mesotrophic conditions.

\section{Temporal Trends in Chemical Loads}

Data from this study indicate that the average annual loads of selected chemical constituents entering Irondequoit Bay, as measured at the Empire Boulevard monitoring site and adjusted for the intervening surface-drainage area, are: total nitrogen, 289 tons, which includes 130 tons of ammonia-plusorganic nitrogen and 159 tons of nitrate-plus-nitrite nitrogen; total phosphorus, 21 tons; total suspended solids, 16,700 tons; dissolved chloride, 19,200 tons; and sulfate, 17,200 tons (table 13). Corresponding

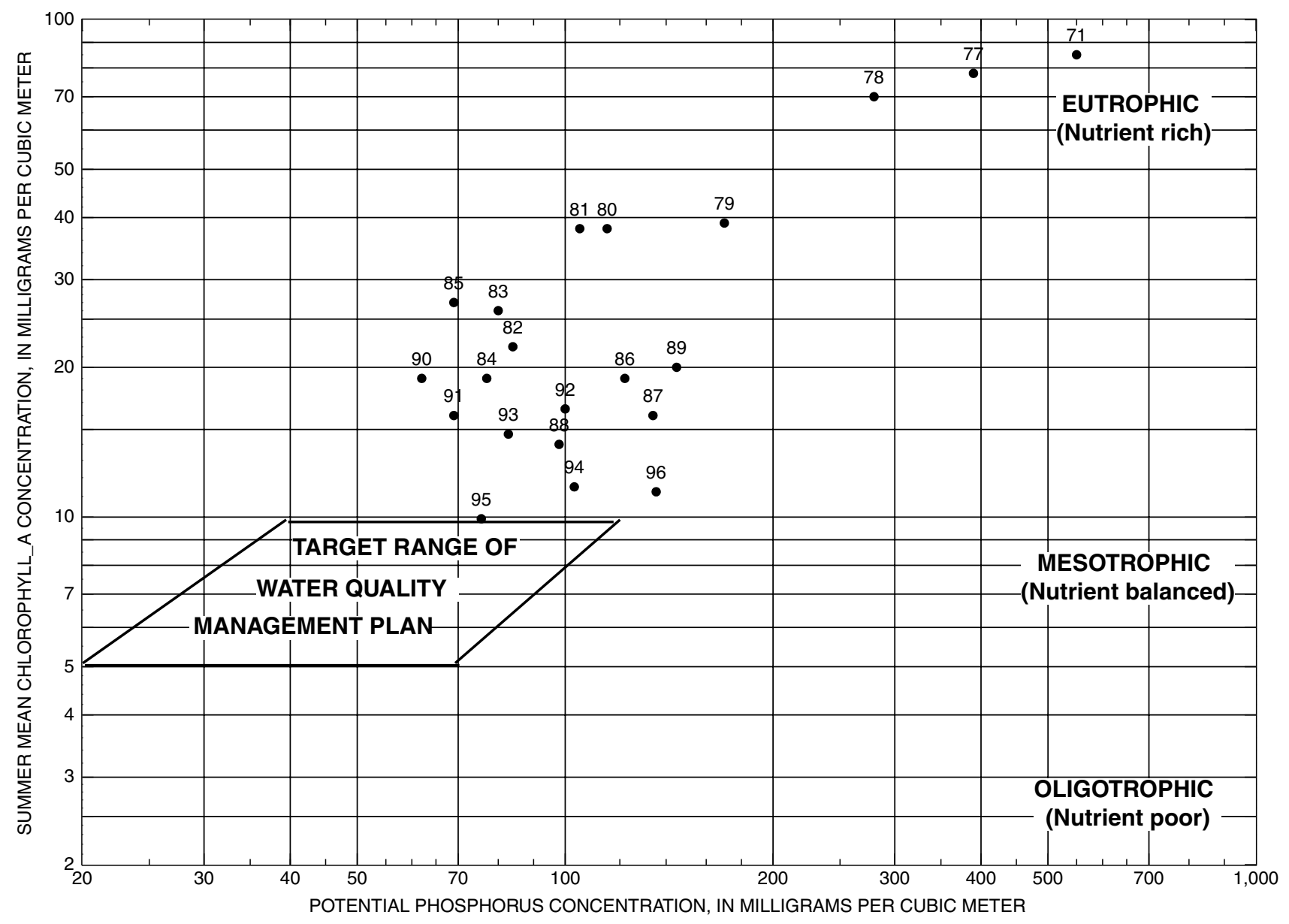

Figure 18. Trophic state of Irondequoit Bay, 1971-96, based on measured chlorophyll_a and computed potentialphosphorus concentrations (Source: Monroe County Environmental Health Laboratory.) 
values calculated from data collected during 1980-81 and 1984-88 (Kappel and others, 1986; Johnston and Sherwood, 1996) should indicate whether decreasing trends are present, but these are difficult to evaluate because the earlier load calculations were based on data collected at the Blossom Road monitoring site (adjusted for intervening surface-drainage area by a multiplier of 1.17). This estimation technique assumed that loading rates from the intervening area (the Ellison Park wetland) were comparable to those from the rest of the basin, whereas the present study (1990-96) indicated that the wetland can have a significant effect on the loads of certain constituents. For example, loads of total phosphorus and total suspended solids were greatly decreased by passage through the wetland; therefore, the estimated loads of these constituents, which were based on the adjusted Blossom Road values, probably exceeded the loads actually entering Irondequoit Bay by about 30 percent for TP and about 50 percent for TSS (based on 1990-96 estimated loads, table 13). Loads of conservative constituents, such as chloride and sulfate, which did not appear to be strongly affected by the wetland, also might have been slightly overestimated, and the loads of ammonia nitrogen and orthophosphate, which increased during passage through the wetland, probably were underestimated by this calculation method.

Comparison of estimated annual loads transported by Irondequoit Creek to Irondequoit Bay during the 1980-81 study (Kappel and others, 1986) with those for 1984-88 (table 13), indicates a decrease in TKN loads (24 tons, 11 percent), and an increase in TP loads (2.9 tons, 14 percent) and TSS loads (9,300 tons, 49 percent); chloride loads to Irondequoit Bay did not change substantially. Some of the differences between the two periods might be attributed to the differing lengths of time spanned by each study - the 1980-81 data provide a 1-year "snapshot" of a dynamic system, whereas the 1984-88 values represent a 5-year period. A comparison of the 198488 data with those from this study, which covered a similar time span, should provide a more reliable basis

Table 13. Estimated average annual loads of selected chemical constituents entering Irondequoit Bay, Monroe County, N.Y.

[All values are in tons. Dash indicates no data available.]

\begin{tabular}{|c|c|c|c|c|}
\hline \multirow[b]{3}{*}{ Constituent } & \multicolumn{4}{|c|}{ Values based on data from } \\
\hline & \multicolumn{3}{|c|}{$\begin{array}{l}\text { Upstream end of wetland } \\
\quad \text { (Blossom Road })^{1}\end{array}$} & \multirow{2}{*}{$\begin{array}{c}\text { Downstream end of wetland } \\
{\text { (Empire Boulevard })^{2}} \\
1990-96^{5}\end{array}$} \\
\hline & $1980-81^{3}$ & $1984-88^{4}$ & $1990-96^{5}$ & \\
\hline Total nitrogen & -- & 383 & 322 & 289 \\
\hline Ammonia-plus-organic nitrogen & 214 & 190 & 148 & 130 \\
\hline Ammonia nitrogen & -- & 6.33 & 3.03 & 5.24 \\
\hline Organic nitrogen & -- & 184 & 145 & 125 \\
\hline Nitrate plus nitrite & -- & 193 & 174 & 159 \\
\hline Total phosphorus & 20.2 & 23.1 & 30.7 & 20.9 \\
\hline Orthophosphate & -- & 2.44 & 1.97 & 2.56 \\
\hline Total suspended solids & 19,100 & 28,400 & 33,300 & 16,700 \\
\hline Volatile suspended solids & -- & 3,170 & 4,140 & 2,290 \\
\hline Nonvolatile suspended solids & -- & 25,200 & 29,200 & 14,400 \\
\hline Chloride & 16,400 & 16,700 & 19,700 & 19,200 \\
\hline Sulfate & -- & 18,700 & 18,700 & 17,200 \\
\hline
\end{tabular}

\footnotetext{
${ }^{1}$ Values are estimated loads computed for Irondequoit Creek at Blossom Road multiplied by 1.17 to account for the drainage area between Blossom Road and the mouth of Irondequoit Bay.

${ }^{2}$ Values are estimated loads computed for Irondequoit Creek at Empire Boulevard multiplied by 1.10 to account for the drainage area between Empire Boulevard and the mouth of Irondequoit Bay.

${ }^{3}$ Data from Kappel and others (1986).

${ }^{4}$ Data from Johnston and Sherwood (1996).

${ }^{5}$ Data from this study, 1990-96.
} 
for discerning long-term temporal trends in constituent loads.

The chemical loads entering Irondequoit Bay as calculated from the 1990-96 data were computed two ways - the first calculation used the Blossom Road (wetland inflow) loads adjusted by the drainage-area multiplier of 1.17 (as was done for the earlier load estimates), and the second used the Empire Boulevard (wetland outflow) loads adjusted by a drainage-area multiplier of 1.10 (table 13). Comparison of these results confirms the potential error inherent in the use of the upstream (Blossom Road) data; that is, overestimation for constituents whose loads are significantly decreased by the wetland, especially total phosphorus, total nitrogen, and total suspended solids, and underestimation for those that are increased in the wetland, such as orthophosphate and ammonia nitrogen. The results indicate that (1) the loads of all major forms of nitrogen entering Irondequoit Bay have decreased since the 1980's, (2) the loads of chloride have increased, (3) the loads of sulfate have remained about the same, and (4) the loads of ammonia nitrogen and orthophosphate entering the Ellison Park wetland have decreased, and (5) the loads of total phosphorus and suspended solids entering the wetland have increased. This increase in TP and TSS loads is possibly a result of increased erosion potential and transport capability of stormflows from an increasingly developed watershed and is substantiated by Young (1996), who documented an increasing rate of sediment accumulation in the floodplain of the lower Irondequoit Creek during the 20th century. The trend in loads of TP, TSS, $\mathrm{NH}_{3}$, and $\mathrm{PO}_{4}$ entering Irondequoit Bay since the 1980's cannot be reliably defined because the removal of TP and TSS and generation of $\mathrm{NH}_{3}$ and $\mathrm{PO}_{4}$ in the wetland during the two earlier study periods are unknown.

\section{SUMMARY}

A 6-year (1990-96) study of the Ellison Park wetland in Monroe County, N.Y., was conducted by the USGS, in cooperation with the Monroe County Department of Health, to document the effect of this predominantly cattail marsh on the chemical quality of Irondequoit Creek, which flows through it. This stream drains $151 \mathrm{mi}^{2}$ of mostly residential and urban land and is the main tributary to Irondequoit Bay. The wetland covers 423 acres and is mostly a palustrine persistent emergent marsh that is divided topographically into a southern and a northern part. Water levels in the wetland are controlled by the water-surface elevation of Irondequoit Bay and Lake Ontario. The seasonal periods of inundation averaged 136 and 189 days in the southern and northern areas, respectively. The average maximum depth of inundation during these periods was $1.1 \mathrm{ft}$ in the southern part and $1.5 \mathrm{ft}$ in the northern part.

Stream-discharge and water-quality data were collected at the inlet and outlet of the wetland, and the chemical loads were computed. Results indicate that the wetland decreased loads of particulate constituents and those chemicals associated with fine-grained sediment and organic matter, presumably through vegetative filtration, precipitation, and sedimentation and removal of adsorbed chemicals. Total-phosphorus and suspended-solids loads were decreased by 28 and 47 percent, respectively, over the 6-year study period, and outflow concentrations of metals (zinc, lead, and cadmium) were significantly lower than inflow concentrations. Ammonia nitrogen and orthophosphate output loads exceeded their input loads ( -38 and -84 percent removal efficiencies, respectively) but represented only 1 to 2 percent of total nitrogen loads and 6 to 12 percent of total phosphorus loads, respectively. The export of these constituents reflects generation through leaching and decomposition of organic matter and the diffusion of ammonia nitrogen from the reduced wetland soils. The loads of other constituents, such as organic nitrogen, nitrate plus nitrite, and sulfate, were decreased by the wetland, but the long-term (6-year) removal efficiencies were low (less than 8 percent). The wetland appeared to have little effect on conservative constituents, such as chloride and sulfate. Removal efficiencies for total phosphorus, orthophosphate, and, possibly, suspended solids, appeared to increase after a diversion- control modification in 1994 that permitted additional stormwater to flow into the southeastern backwater area of the wetland to increase dispersal and detention time. Water temperatures were minimally affected by the wetland during winter, but the summer daily mean outflow temperatures were generally 1 to $2{ }^{\circ} \mathrm{C}$ warmer than the inflow temperatures. The summer differences between outflow and inflow temperatures usually decreased during the passage of storm runoff.

The wetland sediments in open-water areas are predominantly silt sized and smaller and contained relatively small amounts of organic matter. The high 
percentage of fine-grained mineral particles and particulate forms of chemicals, such as suspended solids and phosphorus, that accumulated in these depositional areas are reflected in the wetland's high removal efficiency for these constituents. The relatively low concentrations of organic carbon in the sediments reflect the lower rate of biomass accumulation from small submergent aquatic macrophytes here than would be expected in the cattail-covered areas. The sediments also contained high concentrations of trace metals, including barium, manganese, strontium, and zinc (each of which exceeded $200 \mathrm{ppm}$ during this study), chromium, copper, lead, and vanadium; some polycyclic aromatic hydrocarbons, including chrysene, fluoranthene, phenanthrene, and pyrene; and persistent organochlorine pesticides (chlordane, dieldrin, DDT and its metabolic-degradation products, DDD and DDE) and polychlorinated biphenyls (PCB's).

Cattails, primarily Typha glauca, covered about 63 percent of the wetland, attained a maximum height of $350 \mathrm{~cm}$, a density of more than 30 shoots $/ \mathrm{m}^{2}$, and a total biomass of over $5,600 \mathrm{~g} / \mathrm{m}^{2}, 46$ percent of which was in above-ground tissues during the summer.

Chemical analyses of cattail tissues indicated that the above-ground tissues contained greater

concentrations of nitrogen and potassium (2.4 and 1.5 percent by dry weight, respectively) than the belowground tissues and considerably lower concentrations of all other constituents than the below-ground tissues, except for phosphorus, molybdenum, and manganese, whose concentrations in above-ground tissue were similar to those in below-ground tissue. The concentrations of four elements exceeded those typically found in natural wetlands-manganese (417 ppm) and sodium (3,600 ppm) in above-ground tissues; and aluminum (1,540 ppm), iron $(15,400$ ppm), manganese (433 ppm), and sodium $(10,000$ ppm) in below-ground tissues.

The wetland vegetation undoubtedly assimilated large quantities of nutrients during the growing season as indicated by the large biomass, but neither tissue production nor microbial metabolic processes appeared to appreciably affect the seasonal removalefficiency patterns of surface-water chemical loads. Presumably, internal cycling of nutrients in the sediments and organic detritus, combined with a summer increase in microbially mediated chemical transformations, obscured the effect of vegetative assimilation on surface-water loads. Additionally, confinement of most flows within the banks of Irondequoit Creek, which resulted in passage of storm water through the wetland with little dispersion or detention of water in the cattail and backwater areas of the wetland, diminished the wetland's capability for water-quality improvement. Anaerobic conditions in the wetland soils probably were the reason for generation of ammonia nitrogen (through microbially mediated reduction of nitrate) and orthophosphate (through dissolution of cation-phosphate precipitates). The dominant factors in the chemical-removal efficiency of the wetland are (1) inflow-loading rates, (2) storage and release mechanisms of the sediments (sedimentation, adsorption, filtration, precipitation, dissolution, and resuspension), and (3) accretion and burial of organic matter.

Measurements of chlorophyll_a concentrations and calculations of potential phosphorus concentrations made since the 1970's indicate an improvement in the trophic state of Irondequoit Bay. Estimated annual loads of selected constituents indicated a decrease in loadings of all major forms of nitrogen, an increase in chloride loads, and little change in sulfate loads since 1980. Loads of total phosphorus and suspended solids entering the wetland increased during this period, possibly in response to increased stormflow volume and erosion from increased development in the watershed, but the trends of these loads entering Irondequoit Bay cannot be reliably defined because their removal efficiencies during the 1980's are unknown. Loads of ammonia nitrogen and orthophosphate entering the wetland have decreased, but no trends on loads entering Irondequoit Bay can be stated because the generation of these constituents within the wetland was not taken into account by the earlier studies. Average annual loads (1990-96) of selected constituents entering Irondequoit Bay, as measured at the wetland outflow (Empire Boulevard) monitoring site and adjusted for the intervening surface-drainage area, were estimated to be 289 tons of total nitrogen (including 130 tons of ammonia-plus-organic nitrogen and 159 tons of nitrate-plus-nitrite nitrogen), 21 tons of total phosphorus, 16,700 tons of total suspended solids, 19,200 tons of dissolved chloride, and 17,200 tons of sulfate. 


\section{REFERENCES CITED}

Adamus, P.R., and Stockwell, L.T., 1983, A method for wetland functional assessment- $\mathrm{v}$. I, critical review and evaluation concepts: U.S. Department of Transportation, Federal Highway Administration Report FHWA-IP-82-23, 176 p.

American Public Health Association, American Water Works Association, Water Environment Federation, 1995, Standard methods for examination of water and wastewater, 19th ed.: Washington, D.C., American Public Health Association, paginated by section.

Andrews, N.J., and Pratt, D.C., 1978, The potential of cattails (Typha spp.) as an energy source-Productivity in managed stands: Journal of the Minnesota Academy of Science, v. 44, p. 5-8.

Andrle, R.F., and Carroll, J.R., 1988, The atlas of breeding birds in New York State: Ithaca, N.Y., Cornell University Press, $551 \mathrm{p}$.

Bernard, J.M., and Seischab, F.K., 1991, Flora and vegetation of the Irondequoit Creek and Buttonwood Creek wetlands: Report submitted to U.S. Geological Survey, Ithaca, N.Y., in fulfillment of contractual agreement, $49 \mathrm{p}$.

1997, Vegetation of the wetland near the mouth of Irondequoit Creek, 1996: Report submitted to U.S. Geological Survey, Ithaca, N.Y., in fulfillment of contractual agreement, $23 \mathrm{p}$.

Bernard, J.M., and Gorham, E., 1978, Life history aspects of primary production in sedge wetlands, in Good, R.E., Whigham, D.F., and Simpson, R.L., (eds.), Freshwater wetlands-production processes and management potential: Academic Press, N.Y., p. 3951.

Bernard, J.M., and Fitz, M. L., 1979, Seasonal changes in aboveground primary production and nutrient contents in a central New York Typha glauca ecosystem: Bulletin Torrey Botanical Club, v. 106, p. 37-40.

Boar, R.R., 1996, Temporal variations in nitrogen content of Phragmites australis (Cav.) Trin. ex Steud. from a shallow fertile lake: Aquatic Botany, v. 55, p. 171-181.

Bouldin, D.R., Bernard, J.M., and Lauve, T.E., 1993, Leachate treatment system using constructed wetlands, Town of Fenton sanitary landfill, Broome County, N.Y. Final Report to New York State Energy Research and Development Authority No. 94-2.

Boyd, C.E., 1970, Production, mineral accumulation and pigment concentrations in Typha latifolia and Scirpus americanus: Ecology, v. 51, p. 285-290.

1971, Further studies on productivity, nutrient and pigment relationships in Typha latifolia populations: Bulletin of the Torrey Botanical Club, v. 98 , no. 3 , p. $144-150$.
Boyd, C.E., and Hess, L.W., 1970, Factors influencing shoot production and mineral nutrient levels in Typha latifolia: Ecology, v. 51, no. 2, p. 296-300.

Bray, J.R., 1960, The chlorophyll content of some native and managed plant communities in central Minnesota: Canadian Journal of Botany, v. 38, p. 313-333.

Bray, J.R., Lawrence, D.B., and Pearson, L.C., 1959, Primary production in some Minnesota terrestrial communities: Oikos, v. 10, p. 38-49.

Bubeck, R.C., and Burton, R.S., 1989, Changes in chloride concentrations, mixing patterns, and stratification characteristics of Irondequoit Bay, Monroe County, New York, after decreased use of road-deicing salts, 1974-1984: U.S. Geological Survey Water-Resources Investigations Report 87-4223, 52 p.

Buchanan, T.J., and Somers, W.P., 1968, Stage measurement at gaging stations: U.S. Geological Survey Techniques of Water-Resources Investigations, book 3, chap. A7, $28 \mathrm{p}$.

1969, Discharge measurement at gaging stations: U.S. Geological Survey Techniques of WaterResources Investigations, book 3, chap. A8, 65 p.

Carter, R.W., and Davidian, J., 1968, General procedure for gaging streams: U.S. Geological Survey Techniques of Water-Resources Investigations, book 3, chap. A6, $13 \mathrm{p}$.

Cohn, T.A., 1988, Adjusted maximum likelihood estimation of the moments of lognormal populations from type I censored samples: U.S. Geological Survey Open-File Report 88-350, $34 \mathrm{p}$.

Cohn, T.A., 1995, Recent advances in statistical methods for the estimation of sediment and nutrient transport in rivers: U.S. National Report to International Union of Geodesy and Geophysics 1991-1994, Reviews of Geophysics, Supplement, p. 1117-1123.

Cohn, T.A., DeLong, L.L., Gilroy, E.J., Hirsch, R.M., and Wells, D.K., 1989, Estimating constituent loads: Water Resources Research, v. 25, no. 5, p. 937-942.

Cohn, T.A., Caulder, D.L., Gilroy, E.J., Zynjuk, L.D., and Summers, R.M., 1992, The validity of a simple statistical model for estimating fluvial constituent loads-an empirical study involving nutrient loads entering Chesapeake Bay: Water Resources Research, v. 28 , no. 9 , p. $2353-2363$

Cowardin, L.M., Carter, V., Golet, F.C., and LaRoe, E.T., 1979, Classification of wetlands and deepwater habitats of the United States: U.S. Fish and Wildlife Service, FWS/OBS-79/31, 131 p.

Coon, W.F., 1997, Hydrology, biology, and sedimentology of Ellison Park wetland at the mouth of Irondequoit Creek near Rochester, New York: U.S. Geological Survey Water-Resources Investigations Report 964269, $41 \mathrm{p}$.

Davido, R.L., and Conway, T.E., 1989, Nitrification and denitrification at the Iselin marsh/pond/meadow 
facility: in Hammer, D.A., Constructed wetlands for wastewater treatment-municipal, industrial and agricultural: Chelsea, Mich., Lewis Publishers, p. 477483.

DeGaspari, C., and Bannister, T.T., 1983, Survey of the Irondequoit Creek wetlands-possible effects of shortterm impoundment of storm water behind a proposed flow-regulating structure at the Narrows: Rochester, N.Y., Monroe County Department of Health, Irondequoit Bay Report No. 13, 21 p.

Diment, W.H., Bubeck, R.C., and Deck, B.L., 1974, Effects of deicing salts on the waters of the Irondequoit Bay drainage basin, Monroe County, New York, in Coogan, A.H., ed., Fourth Symposium on Salt: Cleveland, Ohio, Northern Ohio Geological Society, v. 1, p. 391-405.

Durum, W.H., Hem, J.D., and Heidel, S.G., 1971, Reconnaissance of selected minor elements in surface waters of the United States, October 1970: U.S. Geological Survey Circular 643, 49 p.

Fishman, M.J., and Friedman, L.C., (eds.), 1989, Methods for the determination of inorganic substances in water and fluvial sediments: U.S. Geological Survey Techniques of Water-Resources Investigations, book 5, chap. A1, 545 p.

Gadbois, L.E., 1989, Environmental feasibility of using wetlands to treat runoff pollution: U.S. Navy, Naval Ocean Systems Center Technical Report 1321, 29 p.

Gehrels, J., and Mulamoottil, G., 1989, The transformation and export of phosphorus from wetlands: Hydrological Processes, v. 3, p. 365-370.

Harbison, K.G., 1974, Summary of the effects on water quality of the marshlands located in the lower Irondequoit valley: Rochester, N.Y., Monroe County Environmental Management Council, 4 p.

Hem, J.D., 1989, Study and interpretation of the chemical characteristics of natural water, 3rd ed.: U.S. Geological Survey Water-Supply Paper 2254, 263 p.

Hickok, E.A., 1978, Wetlands and organic soils for the control of urban stormwater, in Lake Restoration, Proceedings of a National Conference, Minneapolis, Minn.: U.S. Environmental Protection Agency Report 440/5-79-00, p. 153-158.

Hickok, E.A., Hannaman, M.C., and Wenck, N.C., 1977, Urban runoff treatment methods, volume I, Nonstructural wetland treatment: U.S. Environmental Protection Agency Report 600/2-77-217, $121 \mathrm{p}$.

Hornlein, J.F., Szabo, C.O., Zajd, H.J., Jr., and Mulks, R.L, 1997, Water-Resources Data, New York, Water year 1996, volume 3--Western New York: U.S. Geological Survey Water-Data Report NY-96-3, 284 p.

Hutchinson, G.E., 1975, A treatise on limnology, volume III, limnological botany: New York, John Wiley, 660 p.

Johnston, Carol A., 1991, Sediment and nutrient retention by freshwater wetlands-Effects on surface water quality: Critical Reviews in Environmental Control, v. $21(5,6)$, p. 491-565.

Johnston, W.H., and Sherwood, D.A., 1996, Water Resources of Monroe County, New York, water years 1984-88, with emphasis on water quality in the Irondequoit Creek basin, Part 2-Atmospheric deposition, ground water, streamflow, trends in water quality, and chemical loads to Irondequoit Bay: U.S. Geological Survey Water-Resources Investigations Report 96-4054, 84 p.

Kadlec, J.A., 1987, Nutrient dynamics in wetlands, in Reddy, K.R, and Smith, W.H. (eds.), Aquatic plants for water treatment and resource recovery: Orlando, Fla., Magnolia Publishing Co., p. 393-419.

Kadlec, R.H., and Knight, R.L., 1996, Treatment wetlands: Boca Raton, Lewis Publishers, 893 p.

Kappel, W.M., Yager, R.M., and Zarriello, P.J., 1986, Quantity and quality of urban storm runoff in the Irondequoit Creek basin near Rochester, New York, Part 2-Quality of storm runoff and atmospheric deposition, runoff-quality modeling, and potential of wetlands for sediment and nutrient retention: U.S. Geological Survey Water-Resources Investigations Report 85-4113, 93 p.

Kappel, W.M., and Young, R.A., 1989, Glacial history and geohydrology of the Irondequoit Creek valley, Monroe County, New York: U.S. Geological Survey WaterResources Investigations Report 88-4145, 34 p.

Kennedy, E.J., 1984, Discharge ratings at gaging stations: U.S. Geological Survey Techniques of WaterResources Investigations, book 3, chap. A10, 59 p.

Klopatek, J., 1978, Nutrient dynamics of freshwater riverine marshes and the role of emergent macrophytes, in Good, R.E., Whigham, D.F., and Simpson, R.L., (eds), Freshwater Wetlands-Ecological processes and management potential: New York, Academic Press, p. 195-216.

Laenen, A., 1985, Acoustic velocity meter systems: U.S. Geological Survey Techniques of Water-Resources Investigations, book 3, chap. A17, 38 p.

Livingston, E.H., 1989, Use of wetlands for urbanstormwater management, in Hammer, D.A., Constructed wetlands for wastewater treatment-municipal, industrial, and agricultural: Chelsea, Mich., Lewis Publishers, p. 253-262.

Mason, C.R., and Bryant, R.J., 1975, Production, nutrient content, and decomposition of Phragmites communis Trin. and Typha angustifolia L.: Journal of Ecology, v. 63, p. 71-95.

McNaughton, S.J., 1966, Ecotype function in the Typha community-type: Ecological Monographs, v. 36, no. 4, p. 297-325.

Miller, D.J., and Ringler, N.H., 1992, Effects of storm water retention on the animal community of the upper and lower wetlands of Irondequoit Creek, Rochester, New 
York: Report submitted to U.S. Geological Survey, Ithaca, N.Y., in fulfillment of contractual agreement, $50 \mathrm{p}$.

Mitsch, W.J., and Gosselink, J.G., 1986, Wetlands: New York, VanNostrand Reinhold, 539 p.

National Climatic Data Center, 1996, Local climatological data, 1996 annual summary with comparative data, Rochester, New York: Asheville, N.C., National Climatic Data Center, 8 p.

Northeast Regional Climate Center, 1996, New York Climate-June1996: Ithaca, N.Y., Northeast Regional Climate Center, v. 96, no. 6, 13 p.

O'Brien and Gere, 1983, Nationwide urban runoff program, Irondequoit basin study, final report: Rochester, N.Y., Irondequoit Bay Pure Waters District, 164 p.

Pixley, E.Y., 1982, Rochester Committee for Scientific Information-Studies of pollution control in a lakefront community, 1964-81, Rochester Academy of Science, Proceedings: Rochester N.Y., Rochester Academy of Science, v. 14, no. 2, 243 p.

Prentki, R.T., Gustafson, T.D., and Adams, M.S., 1978, Nutrient movements in lakeshore marshes, in Good, R.E., Whigham, D.F., and Simpson, R.L., (eds), Freshwater Wetlands- Ecological processes and management potential, New York, Academic Press, p. 169-195.

Radtke, D. B., 1997, Bottom-material samples: U.S. Geological Survey Techniques of Water-Resources Investigations, National Field Manual for the Collection of Water-Quality Data, book 9, chap. A8, $48 \mathrm{p}$

Rantz, S.E., and others, 1982, Measurement and computation of streamflow, v. 1, Measurement of stage and discharge; v. 2, Computation of discharge: U.S. Geological Survey Water-Supply Paper 2175, 631 p.

SAS Institute, Inc., 1989, SAS/STAT users guide, version 6, 4th ed, v. 2, Cary, NC: SAS Institute, Inc., 846 p.

SAS Institute, Inc., 1990, SAS procedures guide, version 6, 3rd ed, Cary, NC: SAS Institute, Inc., 705 p.

Schroeder, R.A., 1985, Sediment accumulation rates in Irondequoit Bay, New York, based on lead-210 and cesium-137 geochronology: Northeastern Environmental Science, v. 4, no. 1, p. 23-29.

Shelton, L.R., and Capel, P.D., 1994, Guidelines for collecting and processing samples of streambed sediment for analysis of trace elements and organic contaminants for the National Water-Quality Assessment Program: U.S. Geological Survey OpenFile Report 94-458, 20 p.

Sherwood, D.A., 1997, Water resources of Monroe County, New York, water years 1989-93, with emphasis on water quality in the Irondequoit Creek basin, Part 1-Water-Resources Data: U.S. Geological Survey Open-File Report 97-587, 219 p.
Smith, J.A., Witkowski, P.J., and Fusillo, T.V., 1988, Manmade organic compounds in the surface waters of the United States - a review of current understanding: U.S. Geological Survey Circular 1007, 92 p.

Strecker, E.W., Kersnar, J.M., Driscoll, E.D., and Horner, R.R., 1992, The use of wetlands for controlling stormwater pollution: Washington, D.C., The Terrene Institute, $65 \mathrm{p}$.

Timme, P.J., 1995, National Water Quality Laboratory 1995 services catalog: U.S. Geological Survey Open-file Report 95-352, 120 p.

U.S. Environmental Protection Agency, 1983, Results of the Nationwide Urban Runoff Program, Executive Summary: National Technical Information Service, Accession No. PB84-185545, 24 p. 1993, Natural wetlands and urban stormwater-potential impacts and management: U.S. Environmental Protection Agency Report 843-R-001, $76 \mathrm{p}$.

U.S. Soil Conservation Service, 1985, Soils-hydric soils of the United States: Soil Conservation Service Natural Bulletin no. 430-5-9, 3 p.

Van der Valk, A.G., and Davis, C.B., 1978, Primary production of prairie glacial marshes: in Good, R.E., Whigham, D.F., and Simpson, R.L., (eds.), Freshwater wetlands-production processes and management potential: Academic Press, N.Y., p. 21-37.

Vitosh, M.L., Warncke, D.D., and Lucas, R.E., 1973, Secondary and micronutrients for vegetables and field crops: Extension Bulletin E-486, Cooperative Extension Service, Michigan State University, East Lansing, in Donahue, R.L., Miller, R.W., and Shickluna, J.C., 1977, Soils - an introduction to soils and plant growth: Englewood Cliffs, N.J., PrenticeHall, 626 p.

Vollenweider, R.A., 1976, Advances in defining critical loading levels for phosphorus in lake eutrophication: Memorie dell' Istituto Italiano di Idrobiologia, v. 33, p. 53-83.

Wershaw, R.L., Fishman, M.J., Grabbe, R.R., and Lowe, L.E. (eds.), 1987, Methods for the determination of organic substances in water and fluvial sediments: U.S. Geological Survey Techniques of Water-Resources Investigations, book 5, chap. A3, $80 \mathrm{p}$.

Whigham, D.F., McCormick, J., Good, R.E., and Simpson, R.L., 1978, Biomass and primary production in freshwater tidal wetlands of the Middle Atlantic coast: in Good, R.E., Whigham, D.F., and Simpson, R.L., (eds.), Freshwater wetlands-production processes and management potential: Academic Press, N.Y., p. 3-20.

Windholz, Martha, (Ed.), 1983, The Merck index, an encyclopedia of chemicals, drugs, and biologicals, 10th ed.: Rahway, N.J., Merck and Co., Inc., 1463 p. plus appendixes. 
Woodward-Clyde Consultants, 1994, Contribution of heavy metals to storm water from automotive disc brake pad wear: Oakland, Calif., Woodward-Clyde Consultants, $38 \mathrm{p}$.

1997, Metals control measures plan (v. I) and evaluation of nine metals of concern (v. II): Oakland, Calif., Woodward-Clyde Consultants, paginated by section.

Yager, R.M., Zarriello, P.J., and Kappel, W.M., 1985, Geohydrology of the Irondequoit Creek basin near Rochester, New York: U.S. Geological Survey WaterResources Investigations Report 84-4259, scale 1:24,000, 6 sheets.

Young, R.A., 1996, Historic and recent sedimentation rates and projections from radiocarbon samples, Irondequoit
Creek floodplain study, Ellison Park, Monroe County, NY: Report submitted to Monroe County Department of Health, Rochester, N.Y., 13 p.

Young, R., and Burton, R., 1993, Bluff erosion along Irondequoit Creek in Linear Park: Rochester Committee for Scientific Information, Bulletin 315, $6 \mathrm{p}$.

Zarriello, P.J., Harding, W.E., Yager, R.M., and Kappel, W.M., 1985, Quantity and quality of storm runoff in the Irondequoit Creek basin near Rochester, New York, Part 1-Data-collection network and methods, qualityassurance program, and description of available data: U.S. Geological Survey Open-File Report 84-610, $44 \mathrm{p}$. 


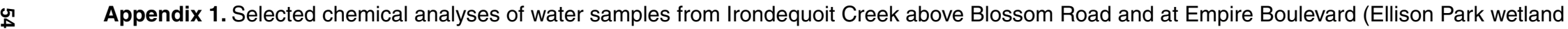
inflow and outflow sites), Monroe County, N.Y., 1990-96

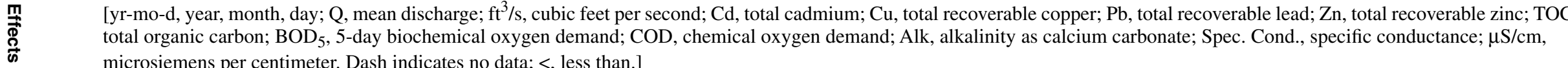

\begin{tabular}{|c|c|c|c|c|c|c|c|c|c|c|c|c|}
\hline \multicolumn{2}{|c|}{$\begin{array}{c}\text { Beginning of } \\
\text { sampling period }\end{array}$} & \multicolumn{2}{|c|}{$\begin{array}{l}\text { End of sampling } \\
\text { period }\end{array}$} & \multirow{2}{*}{$\begin{array}{c}\mathrm{Q} \\
\left(\mathrm{ft}^{3} / \mathrm{s}\right)\end{array}$} & \multicolumn{4}{|c|}{ Metals (micrograms per liter) } & \multicolumn{3}{|c|}{ Physical properties (milligrams per liter) } & \multirow{2}{*}{$\begin{array}{l}\text { Spec. } \\
\text { Cond. } \\
(\mu \mathrm{S} / \mathrm{cm})\end{array}$} \\
\hline Yr-mo-d & Time & Yr-mo-d & Time & & $\mathrm{Cd}$ & $\mathrm{Cu}$ & $\mathrm{Pb}$ & $\mathrm{Zn}$ & TOC & $\mathrm{BOD}_{5}$ & COD & \\
\hline
\end{tabular}

\begin{tabular}{|c|c|c|c|c|c|c|c|c|}
\hline \multicolumn{9}{|c|}{ A. Irondequoit Creek above Blossom Road, Rochester, N.Y. (station 0423205010) } \\
\hline 1990-01-03 & 1915 & 90-01-05 & 0915 & 170 & $<1$ & 50 & $<5$ & 80 \\
\hline 1990-01-18 & 0115 & 90-01-19 & 0915 & 350 & $<1$ & 60 & 82 & 180 \\
\hline 1990-02-08 & 1015 & $90-02-09$ & 0515 & 340 & 1 & 40 & 13 & 70 \\
\hline 1990-02-09 & 0615 & $90-02-12$ & 0915 & 540 & $<1$ & 50 & 32 & 120 \\
\hline $1990-02-22$ & 1535 & $90-02-23$ & 0835 & 500 & 3 & 50 & 30 & 120 \\
\hline 1991-03-02 & 1005 & 91-03-04 & 0305 & 440 & 2 & 90 & 50 & 240 \\
\hline 1991-03-07 & 1105 & 91-03-08 & 1005 & 560 & 1 & 70 & 84 & 260 \\
\hline 1991-03-08 & 1320 & -- & -- & 410 & $<5$ & $<10$ & $<5$ & 40 \\
\hline 1991-03-11 & 1140 & -- & -- & 210 & $<1$ & $<10$ & 7 & $<40$ \\
\hline 1992-02-18 & 1020 & $92-02-19$ & 1320 & 140 & $<1$ & 120 & 6 & 60 \\
\hline 1992-02-18 & 1055 & $92-02-19$ & 1355 & 144 & $<1$ & 60 & $<5$ & 40 \\
\hline 1992-02-19 & 1420 & $92-02-20$ & 0820 & 190 & $<1$ & 50 & 20 & 40 \\
\hline 1992-02-19 & 1455 & $92-02-20$ & 0855 & 186 & $<1$ & 30 & 9 & 40 \\
\hline 1992-02-20 & 0915 & $92-02-22$ & 2015 & 160 & $<1$ & 60 & 5 & 40 \\
\hline 1992-02-20 & 0940 & $92-02-22$ & 2040 & 160 & $<1$ & 20 & -- & 50 \\
\hline $1992-02-22$ & 2115 & $92-02-24$ & 0815 & 190 & $<1$ & 60 & 6 & 40 \\
\hline 1992-02-22 & 2140 & $92-02-24$ & 0840 & 188 & $<1$ & $<20$ & $<5$ & 60 \\
\hline 1992-03-26 & 0915 & $92-03-27$ & 2015 & 610 & 1 & 90 & 56 & 290 \\
\hline 1992-03-27 & 2115 & $92-03-30$ & 0815 & 850 & $<1$ & 90 & 15 & 140 \\
\hline 1992-10-09 & 1330 & $92-10-10$ & 0430 & 299 & 1 & 70 & 16 & 110 \\
\hline 1992-10-10 & 0530 & $92-10-13$ & 1030 & 160 & $<1$ & 40 & 6 & 60 \\
\hline 1992-11-02 & 1030 & $92-11-03$ & 0930 & 312 & 1 & 50 & 7 & 50 \\
\hline 1992-11-03 & 1030 & $92-11-05$ & 0430 & 342 & 3 & 100 & 10 & 40 \\
\hline $1992-12-10$ & 1100 & $92-12-14$ & 1000 & 120 & $<1$ & 60 & $<5$ & $<40$ \\
\hline $1992-12-14$ & 1205 & $92-12-16$ & 0505 & 140 & $<1$ & 80 & $<5$ & 40 \\
\hline 1992-12-16 & 0605 & $92-12-17$ & 1005 & 286 & $<1$ & 70 & 6 & 60 \\
\hline $1992-12-17$ & 1100 & $92-12-18$ & 0200 & 498 & $<1$ & 60 & -- & 80 \\
\hline 1992-12-18 & 0300 & $92-12-21$ & 1000 & 439 & $<1$ & 50 & -- & 70 \\
\hline
\end{tabular}


Appendix 1. Selected chemical analyses of water samples from Irondequoit Creek above Blossom Road and at Empire Boulevard (Ellison Park wetland inflow and outflow sites), Monroe County, N.Y., 1990-96 (continued)

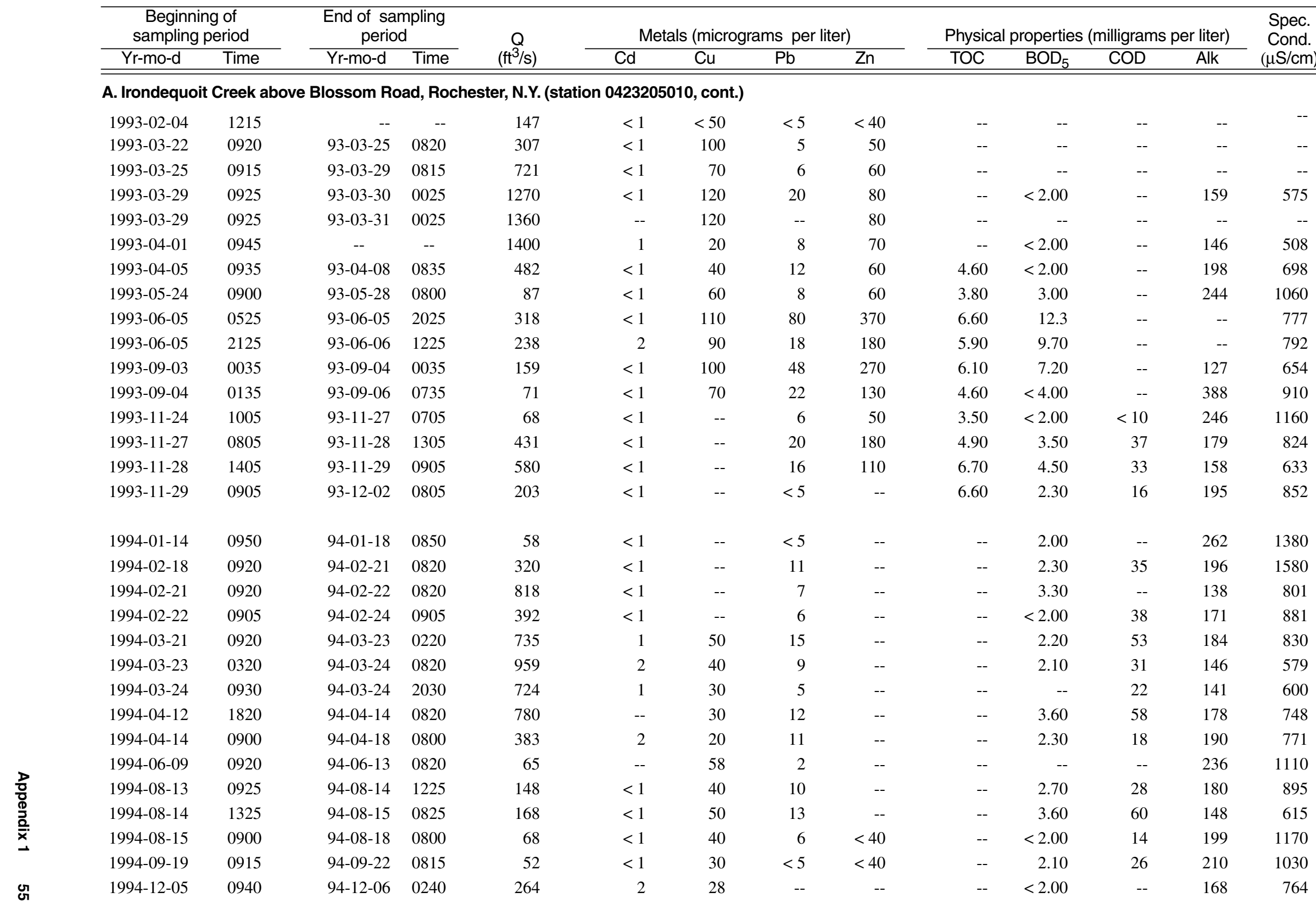


Appendix 1. Selected chemical analyses of water samples from Irondequoit Creek above Blossom Road and at Empire Boulevard (Ellison Park wetland inflow and outflow sites), Monroe County, N.Y., 1990-96 (continued)

\begin{tabular}{|c|c|c|c|c|c|c|c|c|c|c|c|c|c|}
\hline \multicolumn{2}{|c|}{$\begin{array}{c}\text { Beginning of } \\
\text { sampling period }\end{array}$} & \multicolumn{2}{|c|}{$\begin{array}{l}\text { End of sampling } \\
\text { period }\end{array}$} & \multirow{2}{*}{$\begin{array}{c}\mathrm{Q} \\
\left(\mathrm{ft}^{3} / \mathrm{s}\right)\end{array}$} & \multicolumn{4}{|c|}{ Metals (micrograms per liter) } & \multicolumn{4}{|c|}{ Physical properties (milligrams per liter) } & \multirow{2}{*}{$\begin{array}{l}\text { Spec. } \\
\text { Cond. } \\
(\mu \mathrm{S} / \mathrm{cm})\end{array}$} \\
\hline Yr-mo-d & Time & Yr-mo-d & Time & & $\mathrm{Cd}$ & $\mathrm{Cu}$ & $\mathrm{Pb}$ & $\mathrm{Zn}$ & TOC & $\mathrm{BOD}_{5}$ & COD & Alk & \\
\hline \multicolumn{14}{|c|}{ A. Irondequoit Creek above Blossom Road, Rochester, N.Y. (station 0423205010, cont.) } \\
\hline 1994-12-06 & 0340 & $94-12-07$ & 2040 & 190 & 2 & 27 & -- & -- & -- & $<2.00$ & -- & 199 & 962 \\
\hline 1994-12-08 & 0915 & 94-12-09 & 1615 & 138 & $<1$ & 30 & 5 & 40 & -- & $<2.00$ & -- & 221 & 1200 \\
\hline $1994-12-30$ & 0745 & $94-12-31$ & 1845 & 57 & $<1$ & 40 & $<5$ & $<40$ & -- & 2.00 & $<10$ & 257 & 1170 \\
\hline 1995-02-09 & 0930 & $95-02-13$ & 0830 & 60 & $<1$ & $<50$ & $<5$ & $<40$ & -- & $<2.00$ & 18 & 254 & 1450 \\
\hline 1995-03-06 & 1645 & $95-03-08$ & 1250 & 283 & 1 & 20 & $<5$ & 40 & -- & 2.00 & -- & 206 & 1070 \\
\hline 1995-03-08 & 1350 & 95-03-09 & 0750 & 322 & $<1$ & 20 & $<5$ & $<40$ & -- & 2.00 & -- & 185 & 1060 \\
\hline 1995-03-09 & 0815 & $95-03-13$ & 0715 & 222 & $<1$ & 20 & $<5$ & $<40$ & -- & $<2.00$ & -- & 210 & 1210 \\
\hline $1995-03-13$ & 0930 & $95-03-16$ & 0730 & 187 & $<1$ & 20 & 2 & 50 & -- & $<2.00$ & -- & 212 & 1050 \\
\hline 1995-03-16 & 0805 & $95-03-20$ & 0705 & 148 & 1 & 20 & $<2$ & $<40$ & -- & $<2.00$ & -- & 230 & 1170 \\
\hline 1995-05-08 & 1125 & 95-05-09 & 2225 & 52 & $<1$ & $<20$ & 1.7 & $<40$ & -- & $<2.00$ & -- & 231 & -- \\
\hline 1995-05-09 & 2325 & $95-05-11$ & 1025 & 94 & $<1$ & $<20$ & 3 & $<40$ & -- & $<2.00$ & -- & 231 & -- \\
\hline $1995-08-21$ & 1245 & $95-08-24$ & 1045 & 30 & $<1$ & 20 & $<5$ & 30 & 2.3 & $<2.00$ & -- & 211 & 1260 \\
\hline $1995-10-21$ & 0315 & $95-10-21$ & 1815 & 1030 & $<1$ & 30 & 34 & 220 & -- & $<4.00$ & -- & 137 & 526 \\
\hline $1995-10-21$ & 1915 & $95-10-23$ & 1015 & 551 & $<1$ & 30 & 12 & 70 & -- & $<2.00$ & 45 & 129 & 640 \\
\hline $1995-12-11$ & 1200 & $95-12-14$ & 1100 & 58 & $<1$ & 20 & $<5$ & 20 & 6.3 & $<2.00$ & 11 & 280 & 1430 \\
\hline 1996-01-16 & 1045 & $96-01-18$ & 0945 & 189 & $<1$ & 20 & 7 & 55 & 7.20 & $<2.00$ & 33 & 232 & 1700 \\
\hline 1996-01-18 & 1025 & $96-01-19$ & 2125 & 933 & 1 & 70 & 31 & 220 & 7.10 & 8.20 & 186 & 215 & 1160 \\
\hline 1996-01-19 & 2225 & $96-01-22$ & 0525 & 777 & 2 & 80 & 34 & 360 & 10.1 & 14.0 & 255 & 327 & 792 \\
\hline 1996-01-22 & 1125 & $96-01-25$ & 1025 & 336 & $<1$ & 40 & 10 & 45 & 7.60 & 2.00 & -- & 194 & 1150 \\
\hline $1996-01-25$ & 1040 & $96-01-29$ & 0940 & 268 & $<1$ & 30 & 13 & 35 & 5.80 & $<2.00$ & -- & 198 & 1100 \\
\hline 1996-01-29 & 1100 & $96-02-01$ & 1000 & 145 & $<1$ & 20 & 8 & 30 & 5.70 & $<2.00$ & 25 & 239 & 1250 \\
\hline 1996-02-01 & 1045 & $96-02-05$ & 0945 & 86 & $<1$ & 20 & 8 & 25 & 5.20 & $<2.00$ & 23 & 273 & 1340 \\
\hline 1996-04-12 & 1440 & $96-04-14$ & 0140 & 475 & $<1$ & 50 & $<5$ & 30 & 5.60 & 2.30 & -- & 198 & 1020 \\
\hline 1996-04-14 & 0240 & $96-04-15$ & 0940 & 866 & $<1$ & 50 & 9 & 40 & 11.0 & 2.90 & -- & 172 & 695 \\
\hline 1996-04-14 & 1100 & $96-04-17$ & 0820 & 287 & $<1$ & 30 & $<5$ & 20 & 6.20 & $<2.00$ & -- & 200 & 930 \\
\hline 1996-04-18 & 1045 & $96-04-22$ & 0945 & 229 & $<1$ & 20 & $<5$ & 10 & -- & -- & -- & 218 & 1040 \\
\hline
\end{tabular}


Appendix 1. Selected chemical analyses of water samples from Irondequoit Creek above Blossom Road and at Empire Boulevard (Ellison Park wetland inflow and outflow sites), Monroe County, N.Y., 1990-96 (continued)

\begin{tabular}{|c|c|c|c|c|c|c|c|c|c|c|c|c|c|}
\hline \multicolumn{2}{|c|}{$\begin{array}{c}\text { Beginning of } \\
\text { sampling period }\end{array}$} & \multicolumn{2}{|c|}{$\begin{array}{l}\text { End of sampling } \\
\text { period }\end{array}$} & \multirow{2}{*}{$\begin{array}{c}\mathrm{Q} \\
\left(\mathrm{ft}^{3} / \mathrm{s}\right) \\
\end{array}$} & \multicolumn{4}{|c|}{ Metals (micrograms per liter) } & \multicolumn{4}{|c|}{ Physical properties (milligrams per liter) } & \multirow{2}{*}{$\begin{array}{l}\text { Spec. } \\
\text { Cond. } \\
(\mu \mathrm{S} / \mathrm{cm})\end{array}$} \\
\hline Yr-mo-d & Time & Yr-mo-d & Time & & $\mathrm{Cd}$ & $\mathrm{Cu}$ & $\mathrm{Pb}$ & $\mathrm{Zn}$ & TOC & $\mathrm{BOD}_{5}$ & COD & Alk & \\
\hline \multicolumn{14}{|c|}{ B. Irondequoit Creek at Empire Boulevard, Rochester, N.Y. (station 0423205025) } \\
\hline 1991-03-02 & 1825 & 91-03-04 & 0925 & 438 & 1 & 80 & 39 & 150 & -- & -- & -- & -- & 832 \\
\hline 1991-03-06 & 1110 & 91-03-08 & 1010 & 659 & $<1$ & 70 & 13 & 90 & -- & -- & -- & -- & 610 \\
\hline 1991-03-08 & 1015 & $91-03-11$ & 0915 & 291 & $<1$ & 50 & 8 & 60 & -- & -- & -- & -- & 772 \\
\hline 1991-03-12 & 0955 & -- & -- & 175 & $<1$ & $<10$ & $<5$ & $<40$ & -- & -- & -- & -- & -- \\
\hline 1992-02-14 & 1015 & $92-02-15$ & 1715 & 72 & $<1$ & 60 & $<5$ & -- & -- & -- & -- & -- & 1610 \\
\hline 1992-02-15 & 1815 & $92-02-16$ & 1715 & 136 & $<1$ & 70 & 6 & -- & -- & -- & -- & -- & 1800 \\
\hline 1992-02-16 & 1815 & $92-02-17$ & 1915 & 143 & $<1$ & 70 & $<5$ & -- & -- & -- & -- & -- & 1400 \\
\hline 1992-02-18 & 1130 & $92-02-19$ & 1430 & 136 & $<1$ & 70 & 7 & -- & -- & -- & -- & -- & 1310 \\
\hline 1992-02-19 & 1530 & $92-02-20$ & 0930 & 160 & $<1$ & 70 & 7 & -- & -- & -- & -- & -- & 1320 \\
\hline 1992-02-20 & 1015 & $92-02-22$ & 2115 & 148 & $<1$ & 60 & 5 & $<40$ & -- & -- & -- & -- & 1200 \\
\hline 1992-02-22 & 2215 & $92-02-24$ & 0915 & 176 & $<1$ & 50 & $<5$ & $<40$ & -- & -- & -- & -- & 1230 \\
\hline 1992-03-26 & 1000 & $92-03-28$ & 0400 & 714 & 1 & 90 & 37 & 120 & -- & -- & -- & -- & -- \\
\hline 1992-03-28 & 0500 & $92-03-30$ & 0900 & 1010 & 1 & $<50$ & 14 & 90 & -- & -- & -- & -- & -- \\
\hline 1992-10-09 & 0945 & $92-10-10$ & 0845 & 256 & $<1$ & 40 & 8 & 70 & -- & -- & -- & -- & 880 \\
\hline 1992-10-10 & 0945 & $92-10-13$ & 0845 & 167 & $<1$ & 40 & 6 & 60 & -- & -- & -- & -- & 785 \\
\hline 1992-11-02 & 1010 & $92-11-03$ & 2110 & 316 & 1 & 40 & 9 & 70 & -- & -- & -- & -- & 816 \\
\hline 1992-11-03 & 2210 & $92-11-05$ & 0910 & 336 & 1 & 40 & 7 & 70 & -- & -- & -- & -- & 694 \\
\hline 1992-12-10 & 1025 & $92-12-14$ & 0925 & 134 & $<1$ & 60 & $<5$ & 40 & -- & -- & -- & -- & 1460 \\
\hline $1992-12-14$ & 1125 & $92-12-16$ & 0725 & 147 & $<1$ & 80 & $<5$ & 30 & -- & -- & -- & -- & 1300 \\
\hline $1992-12-16$ & 0825 & $92-12-17$ & 0925 & 276 & $<1$ & 90 & $<5$ & 50 & -- & -- & -- & -- & 1210 \\
\hline $1992-12-17$ & 1025 & $92-12-18$ & 0125 & 437 & $<1$ & 70 & -- & 110 & -- & -- & -- & -- & 1020 \\
\hline 1992-12-18 & 0225 & $92-12-21$ & 0925 & 461 & $<1$ & 70 & -- & 80 & -- & -- & -- & -- & 809 \\
\hline 1993-02-01 & 1100 & 93-02-04 & 1000 & 162 & $<1$ & $<50$ & 8 & $<40$ & -- & -- & -- & -- & -- \\
\hline 1993-03-22 & 0950 & $93-03-25$ & 0850 & 325 & $<1$ & 70 & $<5$ & 40 & -- & -- & -- & -- & -- \\
\hline 1993-03-25 & 0950 & 93-03-29 & 0850 & 668 & $<1$ & 90 & $<5$ & 110 & -- & -- & -- & -- & -- \\
\hline 1993-03-29 & 1005 & $93-03-31$ & 0405 & 1260 & $<1$ & 100 & 6 & 65 & -- & $<2.00$ & -- & 160 & 594 \\
\hline 1993-03-29 & 1005 & $93-03-31$ & 0605 & 1250 & $<1$ & 80 & 7 & 50 & -- & $<2.00$ & -- & 159 & 597 \\
\hline 1993-03-31 & 0705 & 93-04-01 & 0905 & 1360 & $<1$ & 70 & 10 & 60 & -- & $<2.00$ & -- & 147 & 516 \\
\hline 1993-04-01 & 1030 & $93-04-03$ & 0130 & 1760 & $<1$ & 90 & 10 & 70 & 5.00 & $<2.00$ & -- & 147 & 483 \\
\hline 1993-04-03 & 0230 & 93-04-05 & 0830 & 1150 & $<1$ & 90 & 5 & 60 & 4.40 & $<2.00$ & -- & 151 & 526 \\
\hline 1993-04-06 & 1015 & 93-04-06 & 1045 & 496 & $<1$ & 70 & 5 & 70 & 4.40 & $<2.00$ & -- & 197 & 698 \\
\hline 1993-04-06 & 1045 & 93-04-08 & 0945 & 442 & $<1$ & 80 & 8 & 70 & 4.30 & $<2.00$ & -- & 196 & 701 \\
\hline
\end{tabular}


Appendix 1. Selected chemical analyses of water samples from Irondequoit Creek above Blossom Road and at Empire Boulevard (Ellison Park wetland inflow and outflow sites), Monroe County, N.Y., 1990-96 (continued)

\begin{tabular}{|c|c|c|c|c|c|c|c|c|c|c|c|c|c|}
\hline \multicolumn{2}{|c|}{$\begin{array}{c}\text { Beginning of } \\
\text { sampling period }\end{array}$} & \multicolumn{2}{|c|}{$\begin{array}{c}\text { End of sampling } \\
\text { period }\end{array}$} & \multirow{2}{*}{$\begin{array}{c}\mathrm{Q} \\
\left(\mathrm{ft}^{3} / \mathrm{s}\right) \\
\end{array}$} & \multicolumn{4}{|c|}{ Metals (micrograms per liter) } & \multicolumn{4}{|c|}{ Physical properties (milligrams per liter) } & \multirow{2}{*}{$\begin{array}{l}\text { Spec. } \\
\text { Cond. } \\
(\mu \mathrm{S} / \mathrm{cm})\end{array}$} \\
\hline Yr-mo-d & Time & Yr-mo-d & Time & & $\mathrm{Cd}$ & $\mathrm{Cu}$ & $\mathrm{Pb}$ & $\mathrm{Zn}$ & TOC & $\mathrm{BOD}_{5}$ & COD & Alk & \\
\hline \multicolumn{14}{|c|}{ B. Irondequoit Creek at Empire Boulevard, Rochester, N.Y. (station 0423205025, cont.) } \\
\hline $1993-05-24$ & 0925 & $93-05-28$ & 0825 & 68 & 1 & 70 & 5 & $<40$ & 4.90 & $<2.00$ & -- & 249 & 1050 \\
\hline 1993-06-05 & 0545 & $93-06-06$ & 0045 & 275 & -- & 60 & 9 & 110 & 6.50 & 2.20 & -- & -- & 939 \\
\hline 1993-06-06 & 0145 & $93-06-07$ & 0845 & 174 & $<1$ & 60 & 12 & 90 & 5.60 & 5.30 & -- & -- & 764 \\
\hline 1993-09-02 & 2015 & 93-09-04 & 0615 & 150 & $<1$ & 30 & 6 & 80 & 4.30 & $<2.00$ & -- & 140 & 735 \\
\hline 1993-09-04 & 0715 & 93-09-07 & 0915 & 106 & $<1$ & 40 & 12 & 60 & 4.50 & $<2.00$ & -- & 155 & 790 \\
\hline 1993-11-24 & 1030 & $93-11-27$ & 1230 & 69 & $<1$ & -- & $<5$ & 40 & 3.50 & $<2.00$ & 14 & 251 & 1170 \\
\hline 1993-11-27 & 1330 & $93-11-28$ & 1330 & 307 & $<1$ & -- & 13 & 60 & 5.00 & $<4.00$ & 27 & 186 & 836 \\
\hline 1993-11-28 & 1430 & $93-11-29$ & 0930 & 591 & $<1$ & -- & 11 & 80 & 7.40 & $<4.00$ & 28 & 144 & 589 \\
\hline 1993-11-29 & 1000 & $93-12-02$ & 0900 & 244 & $<1$ & -- & $<5$ & -- & 6.70 & 2.30 & 14 & 191 & 835 \\
\hline 1994-01-14 & 1030 & $94-01-18$ & 0930 & 64 & $<1$ & -- & $<5$ & -- & -- & $<2.00$ & -- & 260 & 1410 \\
\hline 1994-02-18 & 1025 & $94-02-21$ & 1325 & 362 & $<1$ & -- & 9 & -- & -- & 4.90 & 29 & 186 & 1550 \\
\hline 1994-02-21 & 1425 & $94-02-22$ & 0925 & 976 & $<1$ & -- & 6 & -- & -- & 2.90 & 29 & 126 & 827 \\
\hline 1994-02-22 & 0945 & $94-02-24$ & 0845 & 574 & $<1$ & -- & 5 & -- & -- & $<2.00$ & 38 & 162 & 872 \\
\hline 1994-03-21 & 0950 & $94-03-23$ & 0550 & 582 & 1 & 40 & 12 & -- & -- & 2.60 & 46 & 159 & 818 \\
\hline 1994-03-23 & 0650 & $94-03-24$ & 0850 & 919 & 1 & 30 & 7 & -- & -- & 2.20 & 21 & 131 & 591 \\
\hline 1994-03-24 & 1000 & $94-03-27$ & 0500 & 580 & 1 & 30 & 5 & -- & -- & -- & 20 & 159 & 676 \\
\hline 1994-04-12 & 1555 & 94-04-14 & 0855 & 563 & -- & 20 & 8 & -- & -- & 2.50 & 21 & 178 & 777 \\
\hline 1994-04-14 & 0930 & 94-04-18 & 0830 & 438 & $<1$ & 30 & -- & -- & -- & 2.70 & 22 & 191 & 803 \\
\hline 1994-06-09 & 1035 & 94-06-13 & 0835 & 67 & $<1$ & 29 & 3 & -- & -- & -- & $<10$ & 242 & 1130 \\
\hline 1994-08-13 & 0955 & $94-08-14$ & 1655 & 133 & $<1$ & 30 & 10 & -- & -- & $<2.00$ & 10 & 183 & 960 \\
\hline 1994-08-14 & 1755 & 94-08-15 & 0855 & 180 & $<1$ & 40 & 5 & -- & -- & $<2.00$ & 22 & 120 & 593 \\
\hline 1994-08-15 & 0930 & 94-08-18 & 0830 & 70 & $<1$ & 30 & 5 & $<40$ & -- & $<2.00$ & 11 & 182 & 910 \\
\hline 1994-12-05 & 1005 & $94-12-06$ & 0305 & 259 & 1 & 21 & -- & -- & -- & $<2.00$ & -- & 182 & 832 \\
\hline 1994-12-06 & 0405 & $94-12-08$ & 0905 & 192 & $<1$ & 22 & -- & -- & -- & $<2.00$ & -- & 196 & 1000 \\
\hline 1994-12-08 & 0945 & 94-12-09 & 2045 & 135 & $<1$ & 40 & $<5$ & $<40$ & -- & 2.00 & -- & 216 & 1250 \\
\hline 1994-12-30 & 0815 & $94-12-31$ & 1915 & 54 & -- & 30 & $<5$ & $<40$ & -- & 2.00 & $<10$ & 265 & 1190 \\
\hline
\end{tabular}


Appendix 1. Selected chemical analyses of water samples from Irondequoit Creek above Blossom Road and at Empire Boulevard (Ellison Park wetland inflow and outflow sites), Monroe County, N.Y., 1990-96 (continued)

\begin{tabular}{|c|c|c|c|c|c|c|c|c|c|c|c|c|c|}
\hline \multicolumn{2}{|c|}{$\begin{array}{c}\text { Beginning of } \\
\text { sampling period }\end{array}$} & \multicolumn{2}{|c|}{$\begin{array}{l}\text { End of sampling } \\
\text { period }\end{array}$} & \multirow{2}{*}{$\begin{array}{c}\mathrm{Q} \\
\left(\mathrm{ft}^{3} / \mathrm{s}\right) \\
\end{array}$} & \multicolumn{4}{|c|}{ Metals (micrograms per liter) } & \multicolumn{4}{|c|}{ Physical properties (milligrams per liter) } & \multirow{2}{*}{$\begin{array}{l}\text { Spec. } \\
\text { Cond. } \\
(\mu \mathrm{S} / \mathrm{cm})\end{array}$} \\
\hline Yr-mo-d & Time & Yr-mo-d & Time & & $\mathrm{Cd}$ & $\mathrm{Cu}$ & $\mathrm{Pb}$ & $\mathrm{Zn}$ & TOC & $\mathrm{BOD}_{5}$ & COD & Alk & \\
\hline \multicolumn{14}{|c|}{ B. Irondequoit Creek at Empire Boulevard, Rochester, N.Y. (station 0423205025, cont.) } \\
\hline 1995-02-09 & 1000 & $95-02-13$ & 0900 & 60 & $<1$ & $<50$ & $<5$ & $<40$ & -- & $<2.00$ & 11 & 258 & 1500 \\
\hline 1995-03-06 & 1025 & $95-03-08$ & 0815 & 273 & $<1$ & 20 & $<5$ & $<40$ & -- & $<2.00$ & -- & 206 & 1210 \\
\hline 1995-03-08 & 0915 & 95-03-09 & 0815 & 348 & $<1$ & 20 & $<5$ & $<40$ & -- & $<2.00$ & -- & 182 & 1040 \\
\hline 1995-03-09 & 0845 & $95-03-13$ & 0745 & 237 & $<1$ & 20 & $<5$ & $<40$ & -- & $<2.00$ & -- & 210 & 1260 \\
\hline 1995-03-13 & 0950 & $95-03-16$ & 0750 & 198 & $<1$ & 20 & 2 & $<40$ & -- & $<2.00$ & -- & 213 & 1020 \\
\hline 1995-03-16 & 0835 & $95-03-20$ & 0735 & 147 & 1 & 20 & 3 & 40 & -- & $<2.00$ & -- & 232 & 1170 \\
\hline $1995-05-08$ & 1100 & 95-05-09 & 2200 & 52 & $<1$ & $<20$ & 3.3 & $<40$ & -- & $<2.00$ & -- & 232 & -- \\
\hline 1995-05-09 & 2300 & $95-05-11$ & 1000 & 87 & $<1$ & $<20$ & 4 & 40 & -- & $<2.00$ & -- & 227 & -- \\
\hline $1995-08-21$ & 1215 & $95-08-24$ & 1015 & 32 & $<1$ & 20 & $<5$ & 40 & 3.6 & $<2.00$ & -- & 210 & 1250 \\
\hline $1995-10-21$ & 0250 & $95-10-22$ & 0550 & 664 & $<1$ & 30 & 15 & 65 & -- & $<2.00$ & 39 & 105 & 526 \\
\hline $1995-10-22$ & 0650 & $95-10-23$ & 0950 & 564 & $<1$ & 30 & 7 & 50 & -- & $<2.00$ & 31 & 122 & 644 \\
\hline 1995-12-11 & 1140 & $95-12-14$ & 1040 & 60 & $<1$ & 20 & $<5$ & 10 & 5.60 & $<2.00$ & 10 & 286 & 1490 \\
\hline 1996-01-16 & 1025 & $96-01-18$ & 0925 & 178 & $<1$ & 40 & 5 & 30 & 6.10 & $<2.00$ & 33 & 232 & 1780 \\
\hline 1996-01-18 & 1005 & $96-01-20$ & 0105 & 708 & 4 & 50 & 5 & 35 & 6.90 & 4.00 & 68 & 161 & 1220 \\
\hline 1996-01-20 & 0205 & $96-01-22$ & 0905 & 848 & 4 & 40 & 9 & 40 & 6.90 & 2.40 & 43 & 139 & 822 \\
\hline 1996-01-22 & 1055 & $96-01-25$ & 0955 & 329 & $<1$ & 30 & 8 & 50 & 7.60 & $<2.00$ & -- & 193 & 1170 \\
\hline 1996-01-25 & 1015 & $96-01-29$ & 0915 & 288 & $<1$ & 40 & 6 & 25 & 6.00 & $<2.00$ & -- & 194 & 1120 \\
\hline 1996-01-29 & 1025 & $96-02-01$ & 0925 & 136 & $<1$ & 20 & $<5$ & 15 & 6.00 & $<2.00$ & $<20$ & 238 & 1260 \\
\hline 1996-02-01 & 1020 & $96-02-05$ & 0920 & 94 & $<1$ & 30 & $<5$ & 20 & 5.20 & 2.40 & 28 & 273 & 1360 \\
\hline 1996-04-14 & 1035 & $96-04-17$ & 0935 & 541 & $<1$ & 40 & $<5$ & 20 & 6.10 & 2.10 & -- & 195 & 916 \\
\hline 1996-04-18 & 1025 & $96-04-22$ & 0925 & 222 & $<1$ & 30 & $<5$ & 20 & -- & -- & -- & 219 & 1050 \\
\hline 1996-10-20 & 1820 & $96-10-21$ & 0920 & -- & $<1$ & 50 & 18 & 50 & -- & 3.00 & -- & -- & 524 \\
\hline
\end{tabular}


Appendix 2. Monthly and annual constituent input and output loads and associated errors for Ellison Park wetland, Monroe County, N.Y., 1990-96

\begin{tabular}{|c|c|c|c|c|c|c|c|c|c|c|c|c|c|c|c|c|}
\hline \multicolumn{17}{|c|}{ A. Nitrogen Compounds } \\
\hline \multirow{3}{*}{$\begin{array}{c}\text { Month/ } \\
\text { year }\end{array}$} & \multicolumn{2}{|c|}{ Total nitrogen ${ }^{1}$} & \multicolumn{4}{|c|}{ Ammonia-plus-organic nitrogen } & \multicolumn{4}{|c|}{ Ammonia nitrogen } & \multicolumn{2}{|c|}{ Organic nitrogen ${ }^{2}$} & \multicolumn{4}{|c|}{ Nitrate plus nitrite } \\
\hline & \multirow{2}{*}{$\begin{array}{l}\text { Input } \\
\text { Load } \\
\end{array}$} & \multirow{2}{*}{$\begin{array}{c}\text { Output } \\
\text { Load }\end{array}$} & \multicolumn{2}{|c|}{ Input } & \multicolumn{2}{|c|}{ Output } & \multicolumn{2}{|c|}{ Input } & \multicolumn{2}{|c|}{ Output } & \multirow{2}{*}{$\begin{array}{l}\text { Input } \\
\text { Load } \\
\end{array}$} & \multirow{2}{*}{$\begin{array}{l}\text { Output } \\
\text { Load }\end{array}$} & \multicolumn{2}{|c|}{ Input } & \multicolumn{2}{|c|}{ Output } \\
\hline & & & Load & Error & Load & Error & Load & Error & Load & Error & & & Load & Error & Load & Error \\
\hline $10 / 90$ & 19.24 & 20.01 & 10.82 & 0.99 & 10.91 & 0.76 & 0.18 & 0.04 & 0.18 & 0.03 & 10.63 & 10.72 & 8.42 & 0.43 & 9.10 & 0.41 \\
\hline $11 / 90$ & 20.05 & 20.82 & 10.40 & 0.87 & 10.57 & 0.69 & 0.19 & 0.04 & 0.23 & 0.04 & 10.21 & 10.34 & 9.64 & 0.46 & 10.26 & 0.43 \\
\hline $12 / 90$ & 49.19 & 44.53 & 25.05 & 2.82 & 20.06 & 1.63 & 0.62 & 0.19 & 0.58 & 0.12 & 24.43 & 19.48 & 24.14 & 1.39 & 24.47 & 1.23 \\
\hline $1 / 91$ & 45.24 & 39.17 & 19.59 & 1.86 & 15.07 & 1.17 & 0.68 & 0.16 & 0.57 & 0.11 & 18.92 & 14.51 & 25.64 & 1.27 & 24.09 & 1.10 \\
\hline $2 / 91$ & 36.82 & 31.52 & 14.33 & 1.31 & 11.05 & 0.78 & 0.59 & 0.14 & 0.42 & 0.08 & 13.75 & 10.63 & 22.48 & 1.12 & 20.46 & 0.90 \\
\hline $3 / 91$ & 66.69 & 61.58 & 30.08 & 2.96 & 25.58 & 1.99 & 0.99 & 0.26 & 0.64 & 0.13 & 29.09 & 24.95 & 36.61 & 1.89 & 35.99 & 1.73 \\
\hline $4 / 91$ & 53.98 & 46.39 & 28.03 & 3.01 & 23.94 & 2.08 & 0.62 & 0.16 & 0.43 & 0.09 & 27.40 & 23.51 & 25.95 & 1.34 & 22.45 & 1.09 \\
\hline $5 / 91$ & 25.85 & 19.92 & 13.47 & 1.07 & 11.00 & 0.69 & 0.27 & 0.06 & 0.23 & 0.04 & 13.21 & 10.77 & 12.38 & 0.56 & 8.92 & 0.36 \\
\hline $6 / 91$ & 9.55 & 9.58 & 5.13 & 0.45 & 5.62 & 0.36 & 0.10 & 0.02 & 0.16 & 0.03 & 5.02 & 5.46 & 4.43 & 0.21 & 3.96 & 0.16 \\
\hline 7/91 & 8.38 & 7.70 & 4.57 & 0.38 & 4.45 & 0.28 & 0.10 & 0.02 & 0.15 & 0.02 & 4.46 & 4.30 & 3.82 & 0.18 & 3.26 & 0.13 \\
\hline $8 / 91$ & 7.28 & 7.12 & 3.91 & 0.32 & 3.95 & 0.25 & 0.09 & 0.02 & 0.12 & 0.02 & 3.83 & 3.83 & 3.37 & 0.15 & 3.16 & 0.13 \\
\hline $9 / 91$ & 5.50 & 6.05 & 2.89 & 0.25 & 3.33 & 0.22 & 0.06 & 0.01 & 0.09 & 0.01 & 2.83 & 3.25 & 2.62 & 0.12 & 2.71 & 0.12 \\
\hline WY91 total & 347.78 & 314.38 & 168.27 & 16.27 & 145.54 & 10.92 & 4.49 & 1.14 & 3.80 & 0.72 & 163.78 & 141.74 & 179.50 & 9.11 & 168.84 & 7.79 \\
\hline $10 / 91$ & 6.32 & 7.50 & 3.23 & 0.26 & 4.08 & 0.25 & 0.05 & 0.01 & 0.10 & 0.02 & 3.17 & 3.98 & 3.09 & 0.14 & 3.42 & 0.13 \\
\hline $11 / 91$ & 7.33 & 9.28 & 3.48 & 0.30 & 4.67 & 0.31 & 0.06 & 0.01 & 0.14 & 0.02 & 3.42 & 4.53 & 3.85 & 0.18 & 4.61 & 0.19 \\
\hline $12 / 91$ & 11.85 & 15.24 & 5.14 & 0.51 & 6.64 & 0.46 & 0.13 & 0.03 & 0.27 & 0.05 & 5.01 & 6.37 & 6.72 & 0.35 & 8.60 & 0.38 \\
\hline $1 / 92$ & 13.98 & 17.25 & 5.07 & 0.42 & 6.25 & 0.40 & 0.18 & 0.04 & 0.34 & 0.06 & 4.89 & 5.91 & 8.91 & 0.40 & 11.00 & 0.44 \\
\hline $2 / 92$ & 16.44 & 18.80 & 5.70 & 0.51 & 6.49 & 0.44 & 0.22 & 0.05 & 0.31 & 0.05 & 5.47 & 6.17 & 10.74 & 0.52 & 12.32 & 0.52 \\
\hline $3 / 92$ & 40.42 & 46.78 & 17.94 & 2.15 & 20.26 & 1.80 & 0.49 & 0.14 & 0.56 & 0.11 & 17.45 & 19.69 & 22.48 & 1.24 & 26.52 & 1.28 \\
\hline $4 / 92$ & 43.90 & 42.59 & 21.30 & 1.90 & 20.95 & 1.42 & 0.45 & 0.10 & 0.48 & 0.08 & 20.86 & 20.47 & 22.60 & 1.06 & 21.64 & 0.89 \\
\hline $5 / 92$ & 26.34 & 24.82 & 13.86 & 1.43 & 13.76 & 1.03 & 0.24 & 0.06 & 0.33 & 0.06 & 13.62 & 13.43 & 12.48 & 0.64 & 11.06 & 0.51 \\
\hline $6 / 92$ & 14.93 & 14.19 & 8.07 & 0.66 & 8.21 & 0.53 & 0.14 & 0.03 & 0.26 & 0.04 & 7.93 & 7.95 & 6.85 & 0.31 & 5.98 & 0.24 \\
\hline $7 / 92$ & 33.71 & 28.91 & 20.58 & 2.34 & 16.85 & 1.43 & 0.35 & 0.10 & 0.52 & 0.11 & 20.23 & 16.33 & 13.13 & 0.72 & 12.06 & 0.60 \\
\hline $8 / 92$ & 44.06 & 39.35 & 27.61 & 3.11 & 22.66 & 1.95 & 0.45 & 0.13 & 0.60 & 0.12 & 27.16 & 22.06 & 16.45 & 0.91 & 16.69 & 0.85 \\
\hline $9 / 92$ & 18.03 & 17.57 & 10.06 & 0.87 & 9.49 & 0.63 & 0.16 & 0.04 & 0.25 & 0.04 & 9.90 & 9.24 & 7.97 & 0.37 & 8.08 & 0.34 \\
\hline WY92 total & 277.33 & 282.29 & 142.04 & 14.44 & 140.29 & 10.66 & 2.92 & 0.75 & 4.16 & 0.77 & 139.12 & 136.13 & 135.29 & 6.85 & 142.00 & 6.37 \\
\hline
\end{tabular}

${ }^{1}$ Loads of total nitrogen are computed as the sum of ammonia-plus-organic and nitrate-plus-nitrite nitrogen loads. No associated errors of prediction are available.

${ }^{2}$ Loads of organic nitrogen are computed as the difference between ammonia-plus-organic and ammonia nitrogen loads. No associated errors of prediction are available. 
Appendix 2. Monthly and annual constituent input and output loads and associated errors for Ellison Park wetland, Monroe County, N.Y., $1990-96$ (continued)

\begin{tabular}{|c|c|c|c|c|c|c|c|c|c|c|c|c|c|c|c|c|}
\hline \multicolumn{17}{|c|}{ A. Nitrogen Compounds (continued) } \\
\hline \multirow{3}{*}{$\begin{array}{l}\text { Month/ } \\
\text { water year }\end{array}$} & \multicolumn{2}{|c|}{ Total nitrogen } & \multicolumn{4}{|c|}{ Ammonia-plus-organic nitrogen } & \multicolumn{4}{|c|}{ Ammonia nitrogen } & \multicolumn{2}{|c|}{ Organic nitrogen } & \multicolumn{4}{|c|}{ Nitrate plus nitrite } \\
\hline & \multirow{2}{*}{$\begin{array}{l}\text { Input } \\
\text { Load }\end{array}$} & \multirow{2}{*}{$\begin{array}{l}\text { Output } \\
\text { Load }\end{array}$} & \multicolumn{2}{|c|}{ Input } & \multicolumn{2}{|c|}{ Output } & \multicolumn{2}{|c|}{ Input } & \multicolumn{2}{|c|}{ Output } & \multirow{2}{*}{$\begin{array}{l}\text { Input } \\
\text { Load }\end{array}$} & \multirow{2}{*}{$\begin{array}{l}\text { Output } \\
\text { Load }\end{array}$} & \multicolumn{2}{|c|}{ Input } & \multicolumn{2}{|c|}{ Output } \\
\hline & & & Load & Error & Load & Error & Load & Error & Load & Error & & & Load & Error & Load & Error \\
\hline $10 / 92$ & 15.29 & 16.50 & 8.13 & 0.67 & 8.79 & 0.56 & 0.11 & 0.02 & 0.22 & 0.04 & 8.01 & 8.57 & 7.16 & 0.32 & 7.71 & 0.31 \\
\hline $11 / 92$ & 30.35 & 31.38 & 16.10 & 1.47 & 15.94 & 1.10 & 0.23 & 0.06 & 0.46 & 0.08 & 15.87 & 15.48 & 14.26 & 0.69 & 15.44 & 0.66 \\
\hline $12 / 92$ & 38.69 & 37.92 & 18.26 & 1.78 & 16.46 & 1.17 & 0.37 & 0.10 & 0.71 & 0.13 & 17.89 & 15.75 & 20.43 & 1.05 & 21.46 & 0.95 \\
\hline $1 / 93$ & 53.94 & 52.63 & 22.63 & 1.93 & 19.72 & 1.31 & 0.62 & 0.14 & 1.04 & 0.18 & 22.00 & 18.68 & 31.31 & 1.44 & 32.91 & 1.33 \\
\hline $2 / 93$ & 20.46 & 22.01 & 6.90 & 0.55 & 7.32 & 0.46 & 0.24 & 0.05 & 0.43 & 0.07 & 6.66 & 6.89 & 13.56 & 0.61 & 14.69 & 0.58 \\
\hline $3 / 93$ & 62.43 & 58.18 & 29.05 & 3.49 & 25.15 & 2.16 & 0.67 & 0.19 & 0.80 & 0.16 & 28.38 & 24.34 & 33.38 & 1.89 & 33.03 & 1.57 \\
\hline $4 / 93$ & 79.64 & 74.61 & 40.93 & 4.29 & 37.33 & 3.02 & 0.76 & 0.22 & 0.94 & 0.19 & 40.16 & 36.38 & 38.72 & 2.14 & 37.28 & 1.89 \\
\hline $5 / 93$ & 19.96 & 14.09 & 9.71 & 0.76 & 7.51 & 0.46 & 0.16 & 0.03 & 0.24 & 0.04 & 9.55 & 7.27 & 10.25 & 0.45 & 6.58 & 0.26 \\
\hline $6 / 93$ & 16.98 & 14.51 & 9.03 & 0.76 & 8.23 & 0.53 & 0.14 & 0.03 & 0.31 & 0.05 & 8.90 & 7.92 & 7.95 & 0.37 & 6.29 & 0.26 \\
\hline $7 / 93$ & 8.79 & 8.98 & 4.56 & 0.36 & 4.97 & 0.30 & 0.08 & 0.02 & 0.23 & 0.04 & 4.48 & 4.74 & 4.23 & 0.18 & 4.01 & 0.16 \\
\hline $8 / 93$ & 7.20 & 7.09 & 3.66 & 0.28 & 3.78 & 0.23 & 0.07 & 0.01 & 0.17 & 0.03 & 3.59 & 3.61 & 3.54 & 0.15 & 3.31 & 0.13 \\
\hline 9/93 & 10.38 & 9.59 & 5.38 & 0.46 & 5.03 & 0.33 & 0.08 & 0.02 & 0.18 & 0.03 & 5.30 & 4.85 & 5.01 & 0.23 & 4.57 & 0.19 \\
\hline WY93 total & 364.12 & 347.49 & 174.32 & 16.80 & 160.21 & 11.62 & 3.54 & 0.89 & 5.72 & 1.03 & 170.79 & 154.48 & 189.80 & 9.53 & 187.28 & 8.28 \\
\hline $10 / 93$ & 8.33 & 8.17 & 4.08 & 0.32 & 4.24 & 0.26 & 0.05 & 0.01 & 0.14 & 0.02 & 4.03 & 4.09 & 4.25 & 0.19 & 3.93 & 0.15 \\
\hline $11 / 93$ & 17.05 & 17.52 & 8.49 & 1.09 & 8.54 & 0.70 & 0.11 & 0.04 & 0.32 & 0.07 & 8.37 & 8.21 & 8.56 & 0.53 & 8.99 & 0.46 \\
\hline $12 / 93$ & 16.60 & 17.21 & 6.93 & 0.61 & 7.23 & 0.49 & 0.13 & 0.03 & 0.40 & 0.07 & 6.81 & 6.83 & 9.66 & 0.45 & 9.98 & 0.41 \\
\hline $1 / 94$ & 14.81 & 14.28 & 5.05 & 0.53 & 4.82 & 0.36 & 0.15 & 0.04 & 0.38 & 0.07 & 4.90 & 4.44 & 9.76 & 0.53 & 9.46 & 0.45 \\
\hline 2/94 & 28.08 & 30.53 & 10.28 & 1.36 & 10.58 & 1.04 & 0.30 & 0.10 & 0.63 & 0.14 & 9.98 & 9.95 & 17.80 & 1.10 & 19.95 & 1.12 \\
\hline $3 / 94$ & 53.38 & 52.02 & 21.97 & 2.20 & 20.43 & 1.47 & 0.49 & 0.12 & 0.85 & 0.15 & 21.47 & 19.58 & 31.41 & 1.58 & 31.59 & 1.34 \\
\hline $4 / 94$ & 44.97 & 42.93 & 20.33 & 1.95 & 19.71 & 1.39 & 0.35 & 0.09 & 0.66 & 0.12 & 19.98 & 19.05 & 24.63 & 1.22 & 23.22 & 0.99 \\
\hline $5 / 94$ & 21.51 & 22.36 & 10.17 & 0.81 & 11.63 & 0.72 & 0.14 & 0.03 & 0.42 & 0.07 & 10.02 & 11.21 & 11.34 & 0.51 & 10.73 & 0.42 \\
\hline $6 / 94$ & 12.93 & 12.51 & 6.51 & 0.58 & 6.86 & 0.46 & 0.09 & 0.02 & 0.31 & 0.05 & 6.42 & 6.55 & 6.41 & 0.30 & 5.65 & 0.24 \\
\hline 7/94 & 6.64 & 6.79 & 3.24 & 0.25 & 3.65 & 0.22 & 0.05 & 0.01 & 0.21 & 0.03 & 3.19 & 3.43 & 3.40 & 0.15 & 3.14 & 0.12 \\
\hline $8 / 94$ & 11.54 & 10.61 & 5.88 & 0.55 & 5.43 & 0.38 & 0.09 & 0.02 & 0.27 & 0.05 & 5.79 & 5.16 & 5.66 & 0.28 & 5.18 & 0.23 \\
\hline 9/94 & 8.51 & 8.55 & 4.14 & 0.35 & 4.31 & 0.28 & 0.06 & 0.01 & 0.18 & 0.03 & 4.09 & 4.12 & 4.36 & 0.20 & 4.25 & 0.18 \\
\hline WY94 total & 244.33 & 243.49 & 107.07 & 10.60 & 107.42 & 7.76 & 2.01 & 0.52 & 4.78 & 0.87 & 105.05 & 102.64 & 137.26 & 7.03 & 136.07 & 6.11 \\
\hline
\end{tabular}


Appendix 2. Monthly and annual constituent input and output loads and associated errors for Ellison Park wetland, Monroe County, N.Y., 1990-96 (continued)

A. Nitrogen Compounds (continued)

\begin{tabular}{|c|c|c|c|c|c|c|c|c|c|c|c|c|c|c|c|c|}
\hline \multirow{3}{*}{$\begin{array}{c}\text { Month/ } \\
\text { water year }\end{array}$} & \multicolumn{2}{|c|}{ Total nitrogen } & \multicolumn{4}{|c|}{ Ammonia-plus-organic nitrogen } & \multicolumn{4}{|c|}{ Ammonia nitrogen } & \multicolumn{2}{|c|}{ Organic nitrogen } & \multicolumn{4}{|c|}{ Nitrate plus nitrite } \\
\hline & \multirow{2}{*}{$\begin{array}{l}\text { Input } \\
\text { Load }\end{array}$} & \multirow{2}{*}{$\begin{array}{l}\text { Output } \\
\text { Load }\end{array}$} & \multicolumn{2}{|c|}{ Input } & \multicolumn{2}{|c|}{ Output } & \multicolumn{2}{|c|}{ Input } & \multicolumn{2}{|c|}{ Output } & \multirow{2}{*}{$\begin{array}{l}\text { Input } \\
\text { Load }\end{array}$} & \multirow{2}{*}{$\begin{array}{c}\text { Output } \\
\text { Load }\end{array}$} & \multicolumn{2}{|c|}{ Input } & \multicolumn{2}{|c|}{ Output } \\
\hline & & & Load & Error & Load & Error & Load & Error & Load & Error & & & Load & Error & Load & Error \\
\hline $10 / 94$ & 6.14 & 6.02 & 2.80 & 0.22 & 3.01 & 0.18 & 0.03 & 0.01 & 0.13 & 0.02 & 2.77 & 2.88 & 3.34 & 0.15 & 3.01 & 0.12 \\
\hline $11 / 94$ & 12.38 & 12.09 & 5.77 & 0.65 & 5.79 & 0.50 & 0.07 & 0.02 & 0.25 & 0.05 & 5.70 & 5.54 & 6.61 & 0.35 & 6.30 & 0.32 \\
\hline $12 / 94$ & 18.10 & 17.63 & 7.16 & 0.62 & 6.98 & 0.47 & 0.12 & 0.03 & 0.47 & 0.08 & 7.05 & 6.51 & 10.93 & 0.51 & 10.65 & 0.44 \\
\hline $1 / 95$ & 18.41 & 18.09 & 6.06 & 0.64 & 5.80 & 0.46 & 0.15 & 0.04 & 0.52 & 0.10 & 5.91 & 5.28 & 12.35 & 0.66 & 12.29 & 0.60 \\
\hline $2 / 95$ & 12.68 & 12.50 & 3.61 & 0.32 & 3.74 & 0.26 & 0.10 & 0.02 & 0.34 & 0.06 & 3.51 & 3.41 & 9.06 & 0.44 & 8.76 & 0.38 \\
\hline $3 / 95$ & 25.83 & 25.36 & 8.38 & 0.71 & 8.48 & 0.55 & 0.20 & 0.04 & 0.52 & 0.09 & 8.18 & 7.95 & 17.45 & 0.81 & 16.89 & 0.69 \\
\hline $4 / 95$ & 11.58 & 11.06 & 4.10 & 0.34 & 4.60 & 0.30 & 0.07 & 0.02 & 0.23 & 0.04 & 4.03 & 4.37 & 7.48 & 0.34 & 6.45 & 0.26 \\
\hline $5 / 95$ & 8.60 & 8.51 & 3.54 & 0.29 & 4.21 & 0.27 & 0.05 & 0.01 & 0.21 & 0.04 & 3.49 & 4.00 & 5.06 & 0.23 & 4.29 & 0.17 \\
\hline $6 / 95$ & 6.48 & 6.27 & 2.93 & 0.26 & 3.30 & 0.23 & 0.04 & 0.01 & 0.20 & 0.04 & 2.89 & 3.10 & 3.55 & 0.17 & 2.96 & 0.13 \\
\hline $7 / 95$ & 8.92 & 8.24 & 4.22 & 0.37 & 4.20 & 0.27 & 0.06 & 0.01 & 0.28 & 0.05 & 4.16 & 3.91 & 4.70 & 0.22 & 4.04 & 0.16 \\
\hline $8 / 95$ & 5.96 & 5.70 & 2.74 & 0.26 & 2.80 & 0.20 & 0.04 & 0.01 & 0.19 & 0.03 & 2.70 & 2.61 & 3.21 & 0.16 & 2.90 & 0.13 \\
\hline $9 / 95$ & 4.10 & 3.92 & 1.79 & 0.15 & 1.90 & 0.12 & 0.02 & 0.01 & 0.11 & 0.02 & 1.76 & 1.79 & 2.32 & 0.11 & 2.02 & 0.08 \\
\hline WY95 total & 139.17 & 135.39 & 53.11 & 4.82 & 54.82 & 3.82 & 0.96 & 0.23 & 3.47 & 0.61 & 52.16 & 51.36 & 86.05 & 4.14 & 80.57 & 3.48 \\
\hline $10 / 95$ & 15.00 & 14.63 & 7.65 & 1.26 & 7.14 & 0.72 & 0.07 & 0.03 & 0.29 & 0.07 & 7.58 & 6.84 & 7.35 & 0.53 & 7.49 & 0.44 \\
\hline $11 / 95$ & 18.04 & 18.28 & 7.77 & 0.72 & 7.89 & 0.55 & 0.08 & 0.02 & 0.43 & 0.08 & 7.68 & 7.46 & 10.27 & 0.51 & 10.38 & 0.45 \\
\hline $12 / 95$ & 12.01 & 12.90 & 4.17 & 0.35 & 4.70 & 0.31 & 0.06 & 0.01 & 0.41 & 0.07 & 4.11 & 4.30 & 7.84 & 0.36 & 8.20 & 0.33 \\
\hline $1 / 96$ & 41.21 & 38.58 & 14.99 & 2.07 & 12.20 & 1.16 & 0.31 & 0.11 & 1.13 & 0.26 & 14.69 & 11.07 & 26.21 & 1.70 & 26.38 & 1.47 \\
\hline $2 / 96$ & 26.38 & 26.19 & 7.84 & 0.89 & 7.45 & 0.60 & 0.19 & 0.05 & 0.69 & 0.14 & 7.65 & 6.76 & 18.55 & 1.03 & 18.73 & 0.90 \\
\hline $3 / 96$ & 29.89 & 30.21 & 9.41 & 0.86 & 9.76 & 0.68 & 0.18 & 0.04 & 0.66 & 0.12 & 9.22 & 9.10 & 20.49 & 1.00 & 20.45 & 0.88 \\
\hline $4 / 96$ & 40.74 & 36.36 & 16.71 & 1.80 & 15.29 & 1.19 & 0.22 & 0.06 & 0.73 & 0.14 & 16.49 & 14.56 & 24.03 & 1.29 & 21.07 & 0.98 \\
\hline $5 / 96$ & 39.65 & 32.88 & 18.52 & 2.08 & 15.82 & 1.23 & 0.19 & 0.06 & 0.74 & 0.14 & 18.32 & 15.07 & 21.13 & 1.15 & 17.07 & 0.80 \\
\hline $6 / 96$ & 27.32 & 22.22 & 13.31 & 1.31 & 11.08 & 0.82 & 0.14 & 0.04 & 0.67 & 0.13 & 13.17 & 10.41 & 14.01 & 0.73 & 11.14 & 0.52 \\
\hline $7 / 96$ & 12.23 & 10.19 & 5.48 & 0.46 & 4.83 & 0.32 & 0.07 & 0.01 & 0.38 & 0.06 & 5.41 & 4.45 & 6.76 & 0.32 & 5.36 & 0.23 \\
\hline $8 / 96$ & 7.92 & 7.10 & 3.42 & 0.31 & 3.21 & 0.22 & 0.04 & 0.01 & 0.25 & 0.04 & 3.37 & 2.96 & 4.51 & 0.23 & 3.89 & 0.17 \\
\hline $9 / 96$ & 8.33 & 8.16 & 3.57 & 0.35 & 3.62 & 0.26 & 0.04 & 0.01 & 0.22 & 0.04 & 3.53 & 3.39 & 4.76 & 0.26 & 4.54 & 0.22 \\
\hline WY96 total & 278.72 & 257.69 & 112.81 & 12.46 & 102.99 & 8.07 & 1.59 & 0.45 & 6.62 & 1.28 & 111.22 & 96.37 & 165.90 & 9.12 & 154.70 & 7.40 \\
\hline $\begin{array}{c}\text { Period of } \\
\text { record } \\
1990-96\end{array}$ & 1,651 & 1,581 & 757.64 & 75.39 & 711.27 & 52.84 & 15.52 & 3.98 & 28.55 & 5.29 & 742.12 & 682.73 & 893.80 & 45.79 & 869.45 & 39.43 \\
\hline
\end{tabular}


Appendix 2. Monthly and annual constituent input and output loads and associated errors for Ellison Park wetland, Monroe County, N.Y., 1990-96 (continued)

[Values are in tons. Input and output loads are based on data from Irondequoit Creek above Blossom Road and Irondequoit Creek at Empire Boulevard, respectively. Error is standard error of prediction, which, when multiplied by 1.96 and added to and subtracted from the estimated load, provides 95-percent confidence limits of the load estimate. WY, water year.]

\section{B. Phosphorus Compounds}

\begin{tabular}{|c|c|c|c|c|c|c|c|c|}
\hline \multirow{3}{*}{$\begin{array}{l}\text { Month/ } \\
\text { year }\end{array}$} & \multicolumn{4}{|c|}{ Total phosphorus, as $\mathrm{P}$} & \multicolumn{4}{|c|}{ Orthophosphate, as $\mathrm{P}$} \\
\hline & \multicolumn{2}{|c|}{ Input } & \multicolumn{2}{|c|}{ Output } & \multicolumn{2}{|c|}{ Input } & \multicolumn{2}{|c|}{ Output } \\
\hline & Load & Error & Load & Error & Load & Error & Load & Error \\
\hline $10 / 90$ & 2.36 & 0.47 & 2.39 & 0.28 & 0.16 & 0.02 & 0.23 & 0.02 \\
\hline $11 / 90$ & 1.49 & 0.25 & 1.54 & 0.16 & 0.13 & 0.01 & 0.18 & 0.01 \\
\hline $12 / 90$ & 4.53 & 1.33 & 3.10 & 0.48 & 0.32 & 0.05 & 0.38 & 0.04 \\
\hline $1 / 91$ & 2.53 & 0.56 & 2.05 & 0.29 & 0.21 & 0.03 & 0.25 & 0.03 \\
\hline $2 / 91$ & 1.72 & 0.32 & 1.46 & 0.16 & 0.12 & 0.01 & 0.14 & 0.01 \\
\hline $3 / 91$ & 6.29 & 1.46 & 5.14 & 0.72 & 0.23 & 0.03 & 0.32 & 0.03 \\
\hline $4 / 91$ & 7.20 & 2.11 & 5.48 & 0.94 & 0.20 & 0.03 & 0.28 & 0.03 \\
\hline $5 / 91$ & 2.09 & 0.31 & 1.85 & 0.18 & 0.10 & 0.01 & 0.12 & 0.01 \\
\hline $6 / 91$ & 0.75 & 0.14 & 1.00 & 0.10 & 0.06 & 0.01 & 0.09 & 0.01 \\
\hline $7 / 91$ & 0.75 & 0.12 & 0.92 & 0.09 & 0.07 & 0.01 & 0.11 & 0.01 \\
\hline $8 / 91$ & 0.73 & 0.12 & 0.89 & 0.09 & 0.07 & 0.01 & 0.11 & 0.01 \\
\hline $9 / 91$ & 0.52 & 0.09 & 0.64 & 0.07 & 0.05 & 0.01 & 0.08 & 0.01 \\
\hline WY91 total & 30.94 & 7.27 & 26.44 & 3.55 & 1.72 & 0.23 & 2.30 & 0.21 \\
\hline $10 / 91$ & 0.47 & 0.07 & 0.58 & 0.05 & 0.05 & 0.01 & 0.08 & 0.01 \\
\hline $11 / 91$ & 0.36 & 0.06 & 0.47 & 0.05 & 0.05 & 0.01 & 0.08 & 0.01 \\
\hline $12 / 91$ & 0.46 & 0.10 & 0.60 & 0.07 & 0.06 & 0.01 & 0.11 & 0.01 \\
\hline $1 / 92$ & 0.37 & 0.06 & 0.53 & 0.05 & 0.05 & 0.01 & 0.09 & 0.01 \\
\hline $2 / 92$ & 0.49 & 0.09 & 0.64 & 0.07 & 0.05 & 0.01 & 0.08 & 0.01 \\
\hline $3 / 92$ & 3.73 & 1.16 & 3.64 & 0.65 & 0.13 & 0.02 & 0.25 & 0.03 \\
\hline $4 / 92$ & 3.89 & 0.77 & 3.41 & 0.37 & 0.14 & 0.02 & 0.23 & 0.02 \\
\hline $5 / 92$ & 2.52 & 0.69 & 2.25 & 0.30 & 0.11 & 0.02 & 0.17 & 0.01 \\
\hline $6 / 92$ & 1.20 & 0.19 & 1.35 & 0.13 & 0.09 & 0.01 & 0.15 & 0.01 \\
\hline $7 / 92$ & 6.40 & 1.89 & 4.84 & 0.76 & 0.36 & 0.06 & 0.60 & 0.06 \\
\hline $8 / 92$ & 11.76 & 3.23 & 7.88 & 1.21 & 0.58 & 0.09 & 0.98 & 0.10 \\
\hline $9 / 92$ & 2.33 & 0.40 & 1.99 & 0.21 & 0.17 & 0.02 & 0.28 & 0.02 \\
\hline WY92 total & 33.96 & 8.70 & 28.17 & 3.91 & 1.85 & 0.26 & 3.09 & 0.29 \\
\hline $10 / 92$ & 1.40 & 0.23 & 1.27 & 0.13 & 0.12 & 0.01 & 0.19 & 0.01 \\
\hline $11 / 92$ & 2.65 & 0.51 & 1.98 & 0.22 & 0.23 & 0.03 & 0.33 & 0.03 \\
\hline $12 / 92$ & 2.42 & 0.54 & 1.68 & 0.19 & 0.24 & 0.03 & 0.33 & 0.03 \\
\hline $1 / 93$ & 2.72 & 0.48 & 2.04 & 0.21 & 0.26 & 0.03 & 0.37 & 0.03 \\
\hline $2 / 93$ & 0.57 & 0.09 & 0.63 & 0.06 & 0.06 & 0.01 & 0.09 & 0.01 \\
\hline $3 / 93$ & 8.26 & 2.60 & 4.38 & 0.73 & 0.26 & 0.05 & 0.36 & 0.04 \\
\hline $4 / 93$ & 12.48 & 3.56 & 7.44 & 1.19 & 0.36 & 0.06 & 0.55 & 0.06 \\
\hline $5 / 93$ & 1.33 & 0.20 & 0.89 & 0.08 & 0.08 & 0.01 & 0.09 & 0.01 \\
\hline $6 / 93$ & 1.42 & 0.24 & 1.25 & 0.12 & 0.11 & 0.01 & 0.16 & 0.01 \\
\hline $7 / 93$ & 0.72 & 0.11 & 0.83 & 0.08 & 0.08 & 0.01 & 0.14 & 0.01 \\
\hline $8 / 93$ & 0.65 & 0.10 & 0.67 & 0.06 & 0.08 & 0.01 & 0.12 & 0.01 \\
\hline $9 / 93$ & 1.08 & 0.18 & 0.86 & 0.09 & 0.10 & 0.01 & 0.15 & 0.01 \\
\hline WY93 total & 35.70 & 8.83 & 23.92 & 3.17 & 1.99 & 0.26 & 2.90 & 0.25 \\
\hline
\end{tabular}


Appendix 2. Monthly and annual constituent input and output loads and associated errors for Ellison Park wetland, Monroe County, N.Y., 1990-96 (continued)

\section{B. Phosphorus Compounds (continued)}

\begin{tabular}{|c|c|c|c|c|c|c|c|c|}
\hline \multirow{3}{*}{$\begin{array}{l}\text { Month/ } \\
\text { year }\end{array}$} & \multicolumn{4}{|c|}{ Total phosphorus, as $\mathrm{P}$} & \multicolumn{4}{|c|}{ Orthophosphate, as P } \\
\hline & \multicolumn{2}{|c|}{ Input } & \multicolumn{2}{|c|}{ Output } & \multicolumn{2}{|c|}{ Input } & \multicolumn{2}{|c|}{ Output } \\
\hline & Load & Error & Load & Error & Load & Error & Load & Error \\
\hline $10 / 93$ & 0.61 & 0.09 & 0.49 & 0.05 & 0.07 & 0.01 & 0.09 & 0.01 \\
\hline $11 / 93$ & 1.41 & 0.48 & 0.89 & 0.13 & 0.14 & 0.03 & 0.18 & 0.02 \\
\hline $12 / 93$ & 0.67 & 0.13 & 0.56 & 0.06 & 0.10 & 0.01 & 0.14 & 0.01 \\
\hline $1 / 94$ & 0.44 & 0.11 & 0.35 & 0.05 & 0.06 & 0.01 & 0.08 & 0.01 \\
\hline $2 / 94$ & 1.62 & 0.58 & 1.28 & 0.25 & 0.11 & 0.02 & 0.18 & 0.02 \\
\hline $3 / 94$ & 4.57 & 1.13 & 2.81 & 0.35 & 0.20 & 0.03 & 0.28 & 0.02 \\
\hline $4 / 94$ & 4.28 & 1.01 & 2.82 & 0.34 & 0.18 & 0.02 & 0.25 & 0.02 \\
\hline $5 / 94$ & 1.54 & 0.24 & 1.50 & 0.14 & 0.10 & 0.01 & 0.16 & 0.01 \\
\hline $6 / 94$ & 1.06 & 0.20 & 1.00 & 0.11 & 0.09 & 0.01 & 0.15 & 0.01 \\
\hline $7 / 94$ & 0.52 & 0.08 & 0.56 & 0.05 & 0.07 & 0.01 & 0.11 & 0.01 \\
\hline $8 / 94$ & 1.35 & 0.28 & 1.05 & 0.12 & 0.14 & 0.02 & 0.21 & 0.02 \\
\hline 9/94 & 0.85 & 0.14 & 0.69 & 0.07 & 0.09 & 0.01 & 0.14 & 0.01 \\
\hline WY94 total & 18.92 & 4.45 & 14.00 & 1.71 & 1.36 & 0.18 & 1.98 & 0.17 \\
\hline $10 / 94$ & 0.43 & 0.06 & 0.33 & 0.03 & 0.06 & 0.01 & 0.07 & 0.00 \\
\hline $11 / 94$ & 0.99 & 0.29 & 0.63 & 0.11 & 0.11 & 0.02 & 0.14 & 0.01 \\
\hline $12 / 94$ & 0.76 & 0.13 & 0.53 & 0.06 & 0.12 & 0.01 & 0.14 & 0.01 \\
\hline $1 / 95$ & 0.62 & 0.16 & 0.46 & 0.06 & 0.09 & 0.01 & 0.11 & 0.01 \\
\hline $2 / 95$ & 0.32 & 0.06 & 0.28 & 0.03 & 0.04 & 0.00 & 0.05 & 0.00 \\
\hline $3 / 95$ & 1.07 & 0.18 & 0.84 & 0.08 & 0.08 & 0.01 & 0.11 & 0.01 \\
\hline $4 / 95$ & 0.50 & 0.08 & 0.44 & 0.04 & 0.04 & 0.00 & 0.05 & 0.00 \\
\hline $5 / 95$ & 0.48 & 0.07 & 0.45 & 0.04 & 0.04 & 0.00 & 0.06 & 0.00 \\
\hline $6 / 95$ & 0.46 & 0.08 & 0.43 & 0.05 & 0.05 & 0.01 & 0.07 & 0.01 \\
\hline $7 / 95$ & 0.82 & 0.14 & 0.69 & 0.07 & 0.10 & 0.01 & 0.14 & 0.01 \\
\hline $8 / 95$ & 0.61 & 0.12 & 0.50 & 0.06 & 0.08 & 0.01 & 0.11 & 0.01 \\
\hline $9 / 95$ & 0.37 & 0.06 & 0.28 & 0.03 & 0.05 & 0.01 & 0.06 & 0.00 \\
\hline WY95 total & 7.43 & 1.43 & 5.86 & 0.66 & 0.88 & 0.11 & 1.14 & 0.09 \\
\hline $10 / 95$ & 3.00 & 1.37 & 1.19 & 0.23 & 0.22 & 0.05 & 0.24 & 0.03 \\
\hline $11 / 95$ & 1.32 & 0.25 & 0.80 & 0.09 & 0.17 & 0.02 & 0.20 & 0.02 \\
\hline $12 / 95$ & 0.44 & 0.07 & 0.34 & 0.03 & 0.09 & 0.01 & 0.10 & 0.01 \\
\hline $1 / 96$ & 3.55 & 1.30 & 1.45 & 0.26 & 0.32 & 0.07 & 0.33 & 0.04 \\
\hline $2 / 96$ & 1.28 & 0.39 & 0.78 & 0.11 & 0.12 & 0.02 & 0.14 & 0.01 \\
\hline $3 / 96$ & 1.65 & 0.32 & 1.15 & 0.13 & 0.12 & 0.01 & 0.15 & 0.01 \\
\hline $4 / 96$ & 5.07 & 1.36 & 2.45 & 0.33 & 0.23 & 0.04 & 0.25 & 0.02 \\
\hline $5 / 96$ & 6.52 & 2.06 & 2.81 & 0.39 & 0.31 & 0.05 & 0.32 & 0.03 \\
\hline $6 / 96$ & 4.09 & 0.88 & 2.21 & 0.28 & 0.32 & 0.04 & 0.36 & 0.03 \\
\hline $7 / 96$ & 1.34 & 0.22 & 0.90 & 0.09 & 0.17 & 0.02 & 0.19 & 0.01 \\
\hline $8 / 96$ & 0.93 & 0.17 & 0.63 & 0.07 & 0.13 & 0.02 & 0.15 & 0.01 \\
\hline $9 / 96$ & 1.07 & 0.24 & 0.67 & 0.08 & 0.13 & 0.02 & 0.15 & 0.01 \\
\hline WY96 total & 30.25 & 8.62 & 15.41 & 2.10 & 2.32 & 0.37 & 2.57 & 0.24 \\
\hline $\begin{array}{c}\text { Period of record } \\
1990-96\end{array}$ & 157.19 & 39.30 & 113.81 & 15.11 & 10.12 & 1.42 & 13.97 & 1.25 \\
\hline
\end{tabular}


Appendix 2. Monthly and annual constituent input and output loads and associated errors for Ellison Park wetland, Monroe County, N.Y., 1990-96 (continued)

[Values are in tons. Input and output loads are based on data from Irondequoit Creek above Blossom Road and Irondequoit Creek at Empire Boulevard, respectively. Error is standard error of prediction, which, when multiplied by 1.96 and added to and subtracted from the estimated load, provides 95-percent confidence limits of the load estimate. WY, water year.]

\section{Selected Anions (chloride and sulfate)}

\begin{tabular}{|c|c|c|c|c|c|c|c|c|}
\hline \multirow[b]{3}{*}{ Month/year } & \multicolumn{4}{|c|}{ Chloride } & \multicolumn{4}{|c|}{ Sulfate } \\
\hline & \multicolumn{2}{|c|}{ Input } & \multicolumn{2}{|c|}{ Output } & \multicolumn{2}{|c|}{ Input } & \multicolumn{2}{|c|}{ Output } \\
\hline & Load & Error & Load & Error & Load & Error & Load & Error \\
\hline $10 / 90$ & 874 & 36 & 893 & 38 & 1242 & 46 & 1179 & 40 \\
\hline $11 / 90$ & 1056 & 43 & 1067 & 44 & 1242 & 45 & 1174 & 39 \\
\hline $12 / 90$ & 2249 & 101 & 2206 & 101 & 1739 & 65 & 1627 & 56 \\
\hline $1 / 91$ & 2575 & 105 & 2416 & 103 & 1683 & 61 & 1512 & 50 \\
\hline $2 / 91$ & 2328 & 97 & 2199 & 95 & 1470 & 54 & 1324 & 45 \\
\hline $3 / 91$ & 3232 & 136 & 3215 & 144 & 2112 & 77 & 1991 & 68 \\
\hline $4 / 91$ & 2222 & 92 & 2065 & 91 & 1926 & 70 & 1743 & 59 \\
\hline $5 / 91$ & 1183 & 46 & 1006 & 41 & 1417 & 48 & 1205 & 38 \\
\hline 6/91 & 488 & 20 & 511 & 21 & 813 & 29 & 800 & 26 \\
\hline $7 / 91$ & 436 & 17 & 435 & 18 & 785 & 27 & 741 & 24 \\
\hline $8 / 91$ & 412 & 16 & 426 & 17 & 774 & 27 & 744 & 24 \\
\hline 9/91 & 357 & 15 & 382 & 16 & 702 & 25 & 691 & 23 \\
\hline WY91 total & 17,414 & 725 & 16,821 & 729 & 15,903 & 575 & 14,731 & 490 \\
\hline $10 / 91$ & 441 & 17 & 483 & 19 & 792 & 27 & 799 & 25 \\
\hline $11 / 91$ & 557 & 23 & 642 & 27 & 797 & 28 & 838 & 27 \\
\hline $12 / 91$ & 914 & 39 & 1128 & 48 & 939 & 33 & 1046 & 33 \\
\hline $1 / 92$ & 1248 & 49 & 1520 & 61 & 1017 & 34 & 1113 & 34 \\
\hline $2 / 92$ & 1415 & 59 & 1663 & 71 & 1051 & 37 & 1127 & 36 \\
\hline $3 / 92$ & 2317 & 100 & 2766 & 121 & 1703 & 61 & 1877 & 62 \\
\hline $4 / 92$ & 2184 & 87 & 2257 & 93 & 1922 & 66 & 1908 & 60 \\
\hline $5 / 92$ & 1244 & 52 & 1252 & 54 & 1466 & 50 & 1433 & 45 \\
\hline $6 / 92$ & 741 & 29 & 757 & 31 & 1104 & 37 & 1083 & 34 \\
\hline $7 / 92$ & 1176 & 51 & 1201 & 55 & 1581 & 56 & 1546 & 50 \\
\hline $8 / 92$ & 1441 & 64 & 1521 & 71 & 1873 & 67 & 1875 & 63 \\
\hline $9 / 92$ & 906 & 36 & 940 & 39 & 1361 & 46 & 1335 & 42 \\
\hline WY92 total & 14,584 & 608 & 16,130 & 690 & 15,606 & 543 & 15,981 & 510 \\
\hline $10 / 92$ & 904 & 35 & 961 & 38 & 1315 & 44 & 1321 & 40 \\
\hline $11 / 92$ & 1624 & 67 & 1699 & 72 & 1725 & 60 & 1732 & 55 \\
\hline $12 / 92$ & 2315 & 98 & 2413 & 103 & 1828 & 63 & 1832 & 58 \\
\hline $1 / 93$ & 3482 & 137 & 3672 & 149 & 2150 & 73 & 2168 & 67 \\
\hline $2 / 93$ & 1838 & 73 & 2068 & 84 & 1272 & 44 & 1329 & 42 \\
\hline $3 / 93$ & 3294 & 143 & 3496 & 151 & 2217 & 83 & 2263 & 77 \\
\hline $4 / 93$ & 3426 & 152 & 3528 & 165 & 2627 & 98 & 2638 & 92 \\
\hline $5 / 93$ & 1161 & 45 & 936 & 37 & 1413 & 47 & 1176 & 36 \\
\hline $6 / 93$ & 875 & 34 & 839 & 34 & 1241 & 42 & 1171 & 37 \\
\hline $7 / 93$ & 537 & 20 & 593 & 23 & 920 & 31 & 948 & 29 \\
\hline $8 / 93$ & 485 & 18 & 513 & 20 & 876 & 30 & 868 & 27 \\
\hline $9 / 93$ & 663 & 26 & 649 & 27 & 1087 & 37 & 1021 & 32 \\
\hline WY93 total & 20,605 & 849 & 21,366 & 903 & 18,670 & 651 & 18,467 & 592 \\
\hline
\end{tabular}


Appendix 2. Monthly and annual constituent input and output loads and associated errors for Ellison Park wetland, Monroe County, N.Y., 1990-96 (continued)

\section{Selected Anions (chloride and sulfate) (continued)}

\begin{tabular}{|c|c|c|c|c|c|c|c|c|}
\hline \multirow[b]{3}{*}{ Month/year } & \multicolumn{4}{|c|}{ Chloride } & \multicolumn{4}{|c|}{ Sulfate } \\
\hline & \multicolumn{2}{|c|}{ Input } & \multicolumn{2}{|c|}{ Output } & \multicolumn{2}{|c|}{ Input } & \multicolumn{2}{|c|}{ Output } \\
\hline & Load & Error & Load & Error & Load & Error & Load & Error \\
\hline $10 / 93$ & 633 & 24 & 615 & 24 & 1023 & 34 & 960 & 29 \\
\hline $11 / 93$ & 1108 & 51 & 1165 & 54 & 1271 & 46 & 1283 & 42 \\
\hline $12 / 93$ & 1377 & 54 & 1445 & 58 & 1285 & 43 & 1285 & 40 \\
\hline $1 / 94$ & 1443 & 62 & 1499 & 66 & 1101 & 38 & 1086 & 34 \\
\hline $2 / 94$ & 2197 & 104 & 2510 & 123 & 1398 & 54 & 1484 & 53 \\
\hline $3 / 94$ & 3376 & 138 & 3652 & 150 & 2227 & 79 & 2298 & 74 \\
\hline $4 / 94$ & 2558 & 105 & 2674 & 112 & 2100 & 74 & 2120 & 68 \\
\hline $5 / 94$ & 1298 & 50 & 1412 & 56 & 1516 & 51 & 1569 & 48 \\
\hline $6 / 94$ & 762 & 30 & 804 & 33 & 1108 & 38 & 1114 & 35 \\
\hline $7 / 94$ & 467 & 18 & 517 & 20 & 823 & 28 & 848 & 26 \\
\hline $8 / 94$ & 710 & 29 & 734 & 31 & 1116 & 38 & 1089 & 34 \\
\hline $9 / 94$ & 616 & 24 & 643 & 26 & 1016 & 35 & 995 & 31 \\
\hline WY94 total & 16,545 & 690 & 17,670 & 753 & 15,983 & 559 & 16,131 & 516 \\
\hline $10 / 94$ & 540 & 21 & 524 & 21 & 902 & 30 & 842 & 26 \\
\hline $11 / 94$ & 941 & 40 & 910 & 41 & 1149 & 41 & 1073 & 36 \\
\hline $12 / 94$ & 1555 & 62 & 1573 & 64 & 1371 & 46 & 1325 & 41 \\
\hline $1 / 95$ & 1769 & 77 & 1860 & 84 & 1241 & 43 & 1225 & 39 \\
\hline $2 / 95$ & 1412 & 59 & 1500 & 64 & 1020 & 36 & 1009 & 32 \\
\hline $3 / 95$ & 2282 & 91 & 2422 & 100 & 1611 & 54 & 1602 & 50 \\
\hline $4 / 95$ & 1061 & 43 & 1076 & 44 & 1098 & 37 & 1060 & 33 \\
\hline $5 / 95$ & 704 & 28 & 727 & 30 & 960 & 32 & 942 & 29 \\
\hline $6 / 95$ & 486 & 20 & 503 & 22 & 786 & 28 & 769 & 25 \\
\hline $7 / 95$ & 605 & 24 & 632 & 26 & 955 & 32 & 935 & 29 \\
\hline $8 / 95$ & 457 & 19 & 479 & 21 & 794 & 28 & 768 & 25 \\
\hline $9 / 95$ & 380 & 15 & 374 & 16 & 709 & 25 & 655 & 22 \\
\hline WY95 total & 12,193 & 498 & 12,580 & 532 & 12,595 & 434 & 12,204 & 386 \\
\hline $10 / 95$ & 913 & 47 & 962 & 49 & 1205 & 47 & 1191 & 41 \\
\hline $11 / 95$ & 1370 & 58 & 1410 & 61 & 1426 & 50 & 1385 & 45 \\
\hline $12 / 95$ & 1219 & 48 & 1327 & 54 & 1119 & 38 & 1121 & 35 \\
\hline $1 / 96$ & 3014 & 150 & 3186 & 160 & 1718 & 67 & 1698 & 61 \\
\hline $2 / 96$ & 2419 & 108 & 2630 & 119 & 1448 & 54 & 1445 & 49 \\
\hline $3 / 96$ & 2540 & 104 & 2780 & 116 & 1706 & 61 & 1714 & 56 \\
\hline $4 / 96$ & 2495 & 108 & 2515 & 110 & 1975 & 74 & 1889 & 65 \\
\hline $5 / 96$ & 2061 & 89 & 1994 & 87 & 1977 & 73 & 1836 & 62 \\
\hline $6 / 96$ & 1394 & 60 & 1348 & 60 & 1600 & 60 & 1473 & 51 \\
\hline $7 / 96$ & 809 & 32 & 785 & 32 & 1132 & 41 & 1028 & 34 \\
\hline $8 / 96$ & 601 & 24 & 610 & 25 & 930 & 34 & 867 & 29 \\
\hline $9 / 96$ & 655 & 28 & 678 & 30 & 984 & 37 & 926 & 32 \\
\hline WY96 total & 19,491 & 857 & 20,226 & 904 & 17,220 & 638 & 16,574 & 561 \\
\hline $\begin{array}{c}\text { Period of record } \\
1990-96\end{array}$ & 100,832 & 4,226 & 104,793 & 4,512 & $\mathbf{9 5 , 9 7 8}$ & 3,400 & 94,087 & 3,055 \\
\hline
\end{tabular}


Appendix 2. Monthly and annual constituent input and output loads and associated errors for Ellison Park wetland, Monroe County, N.Y., 1990-96 (continued)

[Values are in tons. Input and output loads are based on data from Irondequoit Creek above Blossom Road and Irondequoit Creek at Empire Boulevard, respectively. Error is standard error of prediction, which, when multiplied by 1.96 and added to and subtracted from the estimated load, provides 95-percent confidence limits of the load estimate. WY, water year.]

\begin{tabular}{|c|c|c|c|c|c|c|c|c|c|c|}
\hline \multicolumn{9}{|c|}{ D. Suspended Solids } & \multirow{2}{*}{\multicolumn{2}{|c|}{$\begin{array}{c}\text { Nonvolatile } \\
\text { suspended solids }{ }^{1}\end{array}$}} \\
\hline \multirow{3}{*}{$\begin{array}{c}\text { Month/ } \\
\text { year }\end{array}$} & \multicolumn{4}{|c|}{ Total suspended solids } & \multicolumn{4}{|c|}{ Volatile suspended solids } & & \\
\hline & \multicolumn{2}{|c|}{ Input } & \multicolumn{2}{|c|}{ Output } & \multicolumn{2}{|c|}{ Input } & \multicolumn{2}{|c|}{ Output } & \multirow{2}{*}{$\begin{array}{l}\text { Input } \\
\text { Load }\end{array}$} & \multirow{2}{*}{$\begin{array}{l}\text { Output } \\
\text { Load }\end{array}$} \\
\hline & Load & Error & Load & Error & Load & Error & Load & Error & & \\
\hline 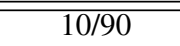 & 2541 & $\overline{7719}$ & 2038 & $\overline{4411}$ & 357 & $\overline{85}$ & $\overline{303}$ & $\overline{446}$ & 2184 & 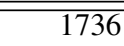 \\
\hline $11 / 90$ & 1815 & 453 & 1470 & 270 & 278 & 60 & 247 & 35 & 1537 & 1222 \\
\hline $12 / 90$ & 5072 & 1755 & 3229 & 791 & 628 & 171 & 453 & 76 & 4444 & 2776 \\
\hline $1 / 91$ & 3390 & 957 & 2267 & 512 & 454 & 105 & 336 & 53 & 2936 & 1931 \\
\hline $2 / 91$ & 2529 & 651 & 1660 & 310 & 343 & 75 & 248 & 35 & 2186 & 1412 \\
\hline $3 / 91$ & 7640 & 2151 & 5317 & 1151 & 848 & 196 & 590 & 91 & 6792 & 4726 \\
\hline $4 / 91$ & 7778 & 2547 & 4882 & 1219 & 816 & 207 & 494 & 82 & 6962 & 4388 \\
\hline $5 / 91$ & 2631 & 553 & 1520 & 234 & 341 & 62 & 199 & 23 & 2291 & 1321 \\
\hline $6 / 91$ & 775 & 200 & 672 & 107 & 117 & 25 & 100 & 12 & 657 & 572 \\
\hline $7 / 91$ & 693 & 157 & 550 & 87 & 110 & 21 & 88 & 11 & 583 & 462 \\
\hline $8 / 91$ & 633 & 144 & 508 & 81 & 105 & 20 & 88 & 11 & 528 & 420 \\
\hline 9/91 & 446 & 109 & 374 & 65 & 80 & 17 & 74 & 10 & 365 & 300 \\
\hline WY91 total & 35,944 & 10,396 & 24,486 & 5,239 & 4,479 & 1,044 & 3,221 & 483 & 31,465 & 21,265 \\
\hline $10 / 91$ & 439 & 97 & 374 & 61 & 83 & 16 & 81 & 10 & 356 & 293 \\
\hline $11 / 91$ & 382 & 93 & 349 & 63 & 74 & 15 & 79 & 11 & 308 & 270 \\
\hline $12 / 91$ & 565 & 166 & 516 & 103 & 99 & 24 & 108 & 16 & 466 & 408 \\
\hline $1 / 92$ & 502 & 122 & 484 & 88 & 92 & 19 & 102 & 14 & 411 & 382 \\
\hline $2 / 92$ & 712 & 179 & 601 & 110 & 116 & 25 & 111 & 16 & 596 & 490 \\
\hline $3 / 92$ & 4088 & 1480 & 3035 & 773 & 467 & 131 & 361 & 61 & 3621 & 2674 \\
\hline $4 / 92$ & 4637 & 1139 & 2769 & 478 & 550 & 111 & 341 & 43 & 4088 & 2428 \\
\hline $5 / 92$ & 2767 & 888 & 1617 & 334 & 339 & 82 & 207 & 29 & 2428 & 1410 \\
\hline $6 / 92$ & 1265 & 272 & 831 & 131 & 181 & 33 & 122 & 15 & 1084 & 708 \\
\hline $7 / 92$ & 5190 & 1774 & 2681 & 638 & 580 & 152 & 310 & 49 & 4610 & 2371 \\
\hline $8 / 92$ & 8481 & 2782 & 4195 & 994 & 912 & 239 & 478 & 79 & 7569 & 3718 \\
\hline 9/92 & 2146 & 494 & 1144 & 195 & 308 & 60 & 188 & 24 & 1838 & 957 \\
\hline WY92 total & 31,175 & 9,487 & 18,595 & 3,967 & 3,800 & 908 & 2,486 & 367 & 27,374 & 16,109 \\
\hline $10 / 92$ & 1395 & 317 & 801 & 136 & 222 & 43 & 153 & 20 & 1173 & 648 \\
\hline $11 / 92$ & 2770 & 700 & 1421 & 265 & 397 & 84 & 251 & 35 & 2373 & 1170 \\
\hline $12 / 92$ & 2741 & 767 & 1358 & 267 & 387 & 88 & 242 & 35 & 2354 & 1116 \\
\hline $1 / 93$ & 3389 & 789 & 1769 & 317 & 470 & 94 & 298 & 41 & 2918 & 1471 \\
\hline $2 / 93$ & 825 & 185 & 558 & 97 & 136 & 27 & 109 & 15 & 688 & 449 \\
\hline $3 / 93$ & 7624 & 2728 & 3369 & 813 & 795 & 225 & 398 & 66 & 6829 & 2971 \\
\hline $4 / 93$ & 11292 & 3500 & 5366 & 1228 & 1148 & 284 & 574 & 92 & 10143 & 4792 \\
\hline $5 / 93$ & 1593 & 329 & 598 & 95 & 223 & 40 & 96 & 12 & 1370 & 503 \\
\hline $6 / 93$ & 1501 & 343 & 737 & 122 & 209 & 40 & 111 & 14 & 1292 & 627 \\
\hline $7 / 93$ & 657 & 138 & 433 & 70 & 106 & 19 & 75 & 9 & 550 & 359 \\
\hline $8 / 93$ & 558 & 115 & 332 & 54 & 96 & 17 & 64 & 8 & 463 & 268 \\
\hline 9/93 & 998 & 233 & 466 & 82 & 159 & 31 & 89 & 12 & 839 & 378 \\
\hline WY93 total & 35,343 & 10,144 & 17,209 & 3,547 & 4,350 & 991 & 2,458 & 359 & 30,993 & 14,751 \\
\hline
\end{tabular}

\footnotetext{
${ }_{1}$ Loads of nonvolatile suspended solids are computed as the difference between total suspended solids and volatile suspended solids. No associated errors of prediction are available.
} 
Appendix 2. Monthly and annual constituent input and output loads and associated errors for Ellison Park wetland, Monroe County, N.Y., 1990-96 (continued)

\begin{tabular}{|c|c|c|c|c|c|c|c|c|c|c|}
\hline \multicolumn{8}{|c|}{ D. Suspended Solids (continued) } & & \multicolumn{2}{|c|}{$\begin{array}{l}\text { Nonvolatile } \\
\text { suspended solids }^{1}\end{array}$} \\
\hline \multirow{2}{*}{$\begin{array}{l}\text { Month/ } \\
\text { year }\end{array}$} & \multicolumn{2}{|c|}{ Input } & \multicolumn{2}{|c|}{ Output } & \multicolumn{2}{|c|}{ Input } & \multicolumn{2}{|c|}{ Output } & \multirow{2}{*}{$\begin{array}{l}\text { Input } \\
\text { Load }\end{array}$} & \multirow{2}{*}{$\begin{array}{l}\text { Output } \\
\text { Load }\end{array}$} \\
\hline & Load & Error & Load & Error & Load & Error & Load & Error & & \\
\hline $10 / 93$ & 600 & 130 & 290 & $\overline{50}$ & 108 & 20 & 66 & 9 & 492 & 224 \\
\hline $11 / 93$ & 1422 & 579 & 634 & 148 & 208 & 63 & 122 & 20 & 1214 & 512 \\
\hline $12 / 93$ & 835 & 217 & 442 & 86 & 142 & 31 & 96 & 14 & 693 & 346 \\
\hline $1 / 94$ & 591 & 199 & 303 & 69 & 99 & 26 & 65 & 11 & 492 & 237 \\
\hline $2 / 94$ & 1931 & 805 & 1102 & 315 & 247 & 79 & 162 & 31 & 1684 & 940 \\
\hline $3 / 94$ & 5271 & 1542 & 2378 & 457 & 607 & 143 & 311 & 43 & 4664 & 2067 \\
\hline $4 / 94$ & 4969 & 1389 & 2247 & 423 & 571 & 128 & 281 & 38 & 4398 & 1966 \\
\hline $5 / 94$ & 1905 & 407 & 1078 & 170 & 257 & 47 & 151 & 18 & 1649 & 927 \\
\hline $6 / 94$ & 1139 & 286 & 617 & 112 & 161 & 33 & 92 & 12 & 977 & 525 \\
\hline $7 / 94$ & 475 & 98 & 299 & 48 & 80 & 14 & 54 & 7 & 395 & 246 \\
\hline $8 / 94$ & 1275 & 345 & 592 & 112 & 185 & 40 & 97 & 13 & 1090 & 496 \\
\hline $9 / 94$ & 822 & 191 & 405 & 72 & 134 & 26 & 77 & 10 & 688 & 328 \\
\hline WY94 total & 21,236 & 6,188 & 10,388 & 2,062 & 2,800 & 651 & 1,574 & 227 & 18,436 & 8,814 \\
\hline $10 / 94$ & 428 & 91 & 203 & 34 & 80 & 15 & 48 & 6 & 348 & 155 \\
\hline $11 / 94$ & 1072 & 391 & 464 & 122 & 163 & 45 & 88 & 15 & 909 & 376 \\
\hline $12 / 94$ & 1021 & 246 & 470 & 85 & 167 & 35 & 97 & 14 & 854 & 373 \\
\hline $1 / 95$ & 895 & 293 & 446 & 104 & 139 & 36 & 85 & 14 & 756 & 361 \\
\hline $2 / 95$ & 504 & 138 & 280 & 56 & 85 & 19 & 56 & 8 & 419 & 224 \\
\hline $3 / 95$ & 1658 & 386 & 842 & 145 & 234 & 47 & 132 & 17 & 1425 & 710 \\
\hline $4 / 95$ & 729 & 167 & 389 & 68 & 112 & 22 & 65 & 9 & 617 & 325 \\
\hline $5 / 95$ & 605 & 138 & 347 & 62 & 94 & 19 & 56 & 8 & 510 & 291 \\
\hline $6 / 95$ & 506 & 128 & 290 & 58 & 79 & 17 & 47 & 7 & 427 & 243 \\
\hline $7 / 95$ & 873 & 213 & 451 & 85 & 129 & 26 & 70 & 10 & 743 & 381 \\
\hline $8 / 95$ & 596 & 167 & 314 & 68 & 94 & 21 & 53 & 8 & 502 & 261 \\
\hline $9 / 95$ & 348 & 81 & 177 & 34 & 63 & 13 & 37 & 6 & 285 & 140 \\
\hline WY95 total & 9,235 & 2,438 & 4,674 & 920 & 1,440 & 314 & 833 & 122 & 7,795 & 3,841 \\
\hline $10 / 95$ & 2738 & 1455 & 953 & 291 & 323 & 128 & 140 & 28 & 2415 & 813 \\
\hline $11 / 95$ & 1741 & 452 & 768 & 153 & 256 & 56 & 135 & 20 & 1485 & 633 \\
\hline $12 / 95$ & 655 & 161 & 363 & 70 & 113 & 24 & 74 & 11 & 542 & 288 \\
\hline $1 / 96$ & 4330 & 1809 & 1697 & 472 & 489 & 160 & 225 & 43 & 3841 & 1472 \\
\hline $2 / 96$ & 2016 & 733 & 978 & 240 & 258 & 73 & 139 & 24 & 1757 & 838 \\
\hline $3 / 96$ & 2755 & 733 & 1422 & 302 & 343 & 77 & 183 & 30 & 2412 & 1239 \\
\hline $4 / 96$ & 6767 & 2215 & 2728 & 674 & 692 & 183 & 280 & 51 & 6076 & 2447 \\
\hline $5 / 96$ & 7824 & 2839 & 2863 & 742 & 770 & 218 & 282 & 54 & 7053 & 2581 \\
\hline $6 / 96$ & 5110 & 1514 & 2044 & 526 & 547 & 137 & 211 & 42 & 4563 & 1833 \\
\hline $7 / 96$ & 1663 & 425 & 769 & 187 & 221 & 49 & 100 & 19 & 1443 & 669 \\
\hline $8 / 96$ & 1072 & 302 & 523 & 132 & 153 & 37 & 76 & 15 & 919 & 447 \\
\hline $9 / 96$ & 1284 & 421 & 615 & 168 & 181 & 49 & 92 & 19 & 1102 & 523 \\
\hline WY96 total & 37,955 & 13,059 & 15,721 & 3,959 & 4,347 & 1,190 & 1,936 & 358 & 33,608 & 13,785 \\
\hline $\begin{array}{c}\text { Period of } \\
\text { record } \\
1990-96\end{array}$ & $\mathbf{1 7 0 , 8 8 8}$ & 51,712 & 91,074 & 19,693 & 21,215 & $\mathbf{5 , 0 9 7}$ & 12,508 & 1,915 & 149,673 & 78,565 \\
\hline
\end{tabular}


Appendix 3. Monthly removal efficiencies for selected constituents as percentage of input load retained in Ellison Park wetland, Monroe County, N.Y., 1990-96 [Values are in percent. Positive and negative values indicate net constituent retention in or export from wetland, respectively. WY, water year. Water year values are based on total annual loads and are not mean monthly values.]

\begin{tabular}{|c|c|c|c|c|c|c|c|c|c|c|c|c|}
\hline \multirow[b]{2}{*}{$\begin{array}{l}\text { Month/ } \\
\text { year }\end{array}$} & \multicolumn{12}{|c|}{ Percent removal } \\
\hline & $\begin{array}{c}\text { Total } \\
\text { nitrogen }\end{array}$ & $\begin{array}{c}\text { Ammonia } \\
\text { plus organic } \\
\text { nitrogen }\end{array}$ & $\begin{array}{l}\text { Ammonia } \\
\text { nitrogen }\end{array}$ & $\begin{array}{l}\text { Organic } \\
\text { nitrogen }\end{array}$ & $\begin{array}{l}\text { Nitrate plus } \\
\text { nitrite }\end{array}$ & $\begin{array}{c}\text { Total } \\
\text { phosphorus }\end{array}$ & $\begin{array}{c}\text { Ortho- } \\
\text { phosphate }\end{array}$ & Chloride & Sulfate & $\begin{array}{c}\text { Total } \\
\text { suspended } \\
\text { solids }\end{array}$ & $\begin{array}{c}\text { Volatile } \\
\text { suspended } \\
\text { solids }\end{array}$ & $\begin{array}{l}\text { Nonvolatile } \\
\text { suspended } \\
\text { solids }\end{array}$ \\
\hline 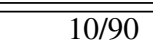 & -4.0 & 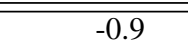 & $\begin{array}{l}-1.1 \\
\end{array}$ & $\begin{array}{l}-0.8 \\
\end{array}$ & $\begin{array}{l}-8.0 \\
\end{array}$ & -1.0 & -45.0 & -2.3 & 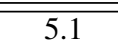 & 19.8 & 15.3 & 20.5 \\
\hline $11 / 90$ & -3.9 & -1.6 & -17.6 & -1.3 & -6.3 & -3.8 & -36.5 & -1.0 & 5.4 & 19.0 & 10.9 & 20.5 \\
\hline $12 / 90$ & 9.5 & 19.9 & 6.9 & 20.3 & -1.4 & 31.7 & -19.2 & 1.9 & 6.4 & 36.3 & 27.8 & 37.5 \\
\hline $1 / 91$ & 13.4 & 23.1 & 16.0 & 23.3 & 6.0 & 19.0 & -20.7 & 6.2 & 10.2 & 33.1 & 26.0 & 34.2 \\
\hline $2 / 91$ & 14.4 & 22.9 & 28.8 & 22.6 & 9.0 & 15.2 & -17.5 & 5.6 & 9.9 & 34.4 & 27.7 & 35.4 \\
\hline $3 / 91$ & 7.7 & 15.0 & 35.8 & 14.2 & 1.7 & 18.3 & -41.3 & 0.5 & 5.7 & 30.4 & 30.4 & 30.4 \\
\hline $4 / 91$ & 14.1 & 14.6 & 30.1 & 14.2 & 13.5 & 23.8 & -39.1 & 7.1 & 9.5 & 37.2 & 39.5 & 37.0 \\
\hline $5 / 91$ & 22.9 & 18.3 & 11.6 & 18.5 & 27.9 & 11.6 & -22.6 & 15.0 & 15.0 & 42.2 & 41.5 & 42.3 \\
\hline 6/91 & -0.3 & -9.7 & -50.9 & -8.8 & 10.5 & -33.7 & -62.5 & -4.6 & 1.5 & 13.3 & 14.3 & 13.1 \\
\hline 7/91 & 8.1 & 2.6 & -46.3 & 3.7 & 14.7 & -23.1 & -53.7 & 0.2 & 5.5 & 20.6 & 19.8 & 20.8 \\
\hline $8 / 91$ & 2.3 & -1.1 & -43.2 & -0.1 & 6.2 & -22.0 & -58.4 & -3.4 & 3.9 & 19.8 & 16.3 & 20.4 \\
\hline 9/91 & -9.9 & -15.5 & -56.0 & -14.7 & -3.6 & -23.3 & -59.0 & -6.9 & 1.6 & 16.2 & 8.2 & 17.9 \\
\hline WY91 & 9.6 & 13.5 & 15.3 & 13.4 & 5.9 & 14.5 & -34.1 & 3.4 & 7.4 & 31.9 & 28.1 & 32.4 \\
\hline $10 / 91$ & -18.7 & -26.4 & -79.9 & -25.5 & -10.6 & -23.9 & -57.7 & -9.5 & -0.9 & 14.9 & 2.8 & 17.8 \\
\hline $11 / 91$ & -26.5 & -34.2 & -117 & -32.6 & -19.6 & -31.4 & -61.7 & -15.3 & -5.2 & 8.6 & -7.3 & 12.4 \\
\hline $12 / 91$ & -28.6 & -29.2 & -114 & -27.1 & -28.0 & -31.2 & -71.8 & -23.4 & -11.4 & 8.8 & -8.6 & 12.5 \\
\hline $1 / 92$ & -23.4 & -23.1 & -85.2 & -20.8 & -23.5 & -42.9 & -70.9 & -21.8 & -9.5 & 3.6 & -11.2 & 6.9 \\
\hline $2 / 92$ & -14.4 & -13.9 & -39.1 & -12.9 & -14.7 & -29.3 & -66.9 & -17.5 & -7.1 & 15.7 & 4.5 & 17.9 \\
\hline $3 / 92$ & -15.7 & -12.9 & -14.3 & -12.8 & -18.0 & 2.5 & -90.5 & -19.4 & -10.2 & 25.8 & 22.7 & 26.1 \\
\hline $4 / 92$ & 3.0 & 1.7 & -8.1 & 1.9 & 4.2 & 12.2 & -57.0 & -3.3 & 0.7 & 40.3 & 38.0 & 40.6 \\
\hline $5 / 92$ & 5.8 & 0.7 & -36.5 & 1.4 & 11.3 & 10.5 & -56.4 & -0.7 & 2.3 & 41.6 & 39.1 & 41.9 \\
\hline $6 / 92$ & 4.9 & -1.7 & -81.4 & -0.3 & 12.7 & -12.3 & -64.9 & -2.2 & 1.9 & 34.3 & 32.6 & 34.6 \\
\hline 7/92 & 14.2 & 18.1 & -48.0 & 19.3 & 8.1 & 24.4 & -66.3 & -2.2 & 2.2 & 48.3 & 46.6 & 48.6 \\
\hline $8 / 92$ & 10.7 & 17.9 & -35.4 & 18.8 & -1.5 & 33.0 & -70.1 & -5.6 & -0.1 & 50.5 & 47.6 & 50.9 \\
\hline 9/92 & 2.6 & 5.7 & -59.4 & 6.7 & -1.3 & 14.5 & -58.6 & -3.7 & 1.9 & 46.7 & 39.0 & 48.0 \\
\hline WY92 & -1.8 & 1.2 & -42.2 & 2.2 & -5.0 & 17.1 & -67.1 & -10.6 & -2.4 & 40.4 & 34.6 & 41.2 \\
\hline
\end{tabular}


ป Appendix 3. Monthly removal efficiencies for selected constituents as percentage of input load retained in Ellison Park wetland, Monroe County, N.Y., 1990-96 (continued)

\begin{tabular}{|c|c|c|c|c|c|c|c|c|c|c|c|c|}
\hline \multirow[b]{2}{*}{$\begin{array}{l}\text { Month/ } \\
\text { year }\end{array}$} & \multicolumn{12}{|c|}{ Percent removal } \\
\hline & $\begin{array}{c}\text { Total } \\
\text { nitrogen }\end{array}$ & $\begin{array}{c}\text { Ammonia } \\
\text { plus organic } \\
\text { nitrogen }\end{array}$ & $\begin{array}{l}\text { Ammonia } \\
\text { nitrogen }\end{array}$ & $\begin{array}{l}\text { Organic } \\
\text { nitrogen }\end{array}$ & $\begin{array}{l}\text { Nitrate plus } \\
\text { nitrite }\end{array}$ & $\begin{array}{c}\text { Total } \\
\text { phosphorus }\end{array}$ & $\begin{array}{c}\text { Ortho- } \\
\text { phosphate }\end{array}$ & Chloride & Sulfate & $\begin{array}{c}\text { Total } \\
\text { suspended } \\
\text { solids }\end{array}$ & $\begin{array}{c}\text { Volatile } \\
\text { suspended } \\
\text { solids }\end{array}$ & $\begin{array}{c}\text { Nonvolatile } \\
\text { suspended } \\
\text { solids }\end{array}$ \\
\hline $10 / 92$ & -8.0 & -8.2 & -97.4 & -6.9 & -7.7 & 8.9 & -56.4 & 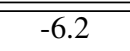 & 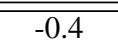 & $\overline{42.6}$ & 31.1 & 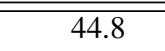 \\
\hline $11 / 92$ & -3.4 & 1.0 & -98.5 & 2.4 & -8.3 & 25.3 & -46.3 & -4.7 & -0.4 & 48.7 & 36.9 & 50.7 \\
\hline $12 / 92$ & 2.0 & 9.9 & -90.4 & 11.9 & -5.1 & 30.6 & -36.0 & -4.2 & -0.2 & 50.4 & 37.5 & 52.6 \\
\hline $1 / 93$ & 2.4 & 12.9 & -66.2 & 15.1 & -5.1 & 25.0 & -41.7 & -5.4 & -0.8 & 47.8 & 36.6 & 49.6 \\
\hline $2 / 93$ & -7.6 & -6.0 & -76.7 & -3.5 & -8.3 & -10.3 & -56.9 & -12.5 & -4.5 & 32.4 & 20.3 & 34.7 \\
\hline $3 / 93$ & 6.8 & 13.4 & -19.3 & 14.2 & 1.1 & 47.0 & -37.4 & -6.1 & -2.1 & 55.8 & 49.9 & 56.5 \\
\hline $4 / 93$ & 6.3 & 8.8 & -23.6 & 9.4 & 3.7 & 40.4 & -52.4 & -3.0 & -0.4 & 52.5 & 50.0 & 52.8 \\
\hline $5 / 93$ & 29.4 & 22.6 & -54.1 & 23.9 & 35.8 & 32.5 & -10.9 & 19.4 & 16.8 & 62.4 & 57.1 & 63.3 \\
\hline $6 / 93$ & 14.5 & 8.9 & -120 & 11.0 & 20.9 & 12.3 & -48.5 & 4.2 & 5.6 & 50.9 & 47.0 & 51.5 \\
\hline 7/93 & -2.2 & -9.0 & -187 & -5.8 & 5.2 & -15.4 & -75.2 & -10.5 & -3.1 & 34.0 & 29.9 & 34.8 \\
\hline $8 / 93$ & 1.6 & -3.3 & -163 & -0.4 & 6.7 & -2.3 & -59.8 & -5.7 & 0.9 & 40.5 & 33.5 & 42.0 \\
\hline 9/93 & 7.6 & 6.5 & -122 & 8.4 & 8.8 & 20.8 & -41.8 & 2.1 & 6.1 & 53.3 & 44.4 & 55.0 \\
\hline WY93 & 4.6 & 8.1 & -61.8 & 9.5 & 1.3 & 33.0 & -45.5 & -3.7 & 1.1 & 51.3 & 43.5 & 52.4 \\
\hline $10 / 93$ & 2.0 & -3.8 & -167 & -1.6 & 7.5 & 19.5 & -31.8 & 3.0 & 6.2 & 51.6 & 39.1 & 54.4 \\
\hline $11 / 93$ & -2.8 & -0.6 & -181 & 1.9 & -4.9 & 36.6 & -32.8 & -5.2 & -0.9 & 55.4 & 41.3 & 57.8 \\
\hline $12 / 93$ & -3.7 & -4.3 & -214 & -0.4 & -3.3 & 16.5 & -37.9 & -4.9 & -0.0 & 47.0 & 32.5 & 50.0 \\
\hline $1 / 94$ & 3.5 & 4.5 & -160 & 9.4 & 3.1 & 19.6 & -27.8 & -3.9 & 1.3 & 48.8 & 33.9 & 51.8 \\
\hline $2 / 94$ & -8.7 & -2.9 & -112 & 0.3 & -12.1 & 21.1 & -63.3 & -14.3 & -6.1 & 43.0 & 34.6 & 44.2 \\
\hline $3 / 94$ & 2.5 & 7.0 & -72.0 & 8.8 & -0.6 & 38.5 & -40.7 & -8.2 & -3.2 & 54.9 & 48.8 & 55.7 \\
\hline $4 / 94$ & 4.5 & 3.1 & -88.2 & 4.6 & 5.8 & 34.1 & -44.0 & -4.5 & -1.0 & 54.8 & 50.7 & 55.3 \\
\hline $5 / 94$ & -4.0 & -14.4 & -187 & -11.9 & 5.4 & 2.4 & -66.5 & -8.8 & -3.5 & 43.4 & 41.2 & 43.8 \\
\hline $6 / 94$ & 3.2 & -5.4 & -241 & -2.0 & 12.0 & 5.5 & -59.3 & -5.5 & -0.5 & 45.8 & 43.0 & 46.3 \\
\hline 7/94 & -2.2 & -12.5 & -306 & -7.6 & 7.5 & -7.4 & -61.9 & -10.8 & -3.0 & 37.0 & 32.8 & 37.8 \\
\hline $8 / 94$ & 8.0 & 7.7 & -206 & 10.9 & 8.4 & 22.4 & -47.2 & -3.5 & 2.4 & 53.5 & 47.7 & 54.5 \\
\hline $9 / 94$ & -0.5 & -3.9 & -231 & -0.8 & 2.7 & 19.1 & -43.3 & -4.3 & 2.0 & 50.8 & 42.5 & 52.4 \\
\hline WY94 & 0.3 & 0.0 & -137 & 2.3 & 0.1 & 26.0 & -46.0 & -6.8 & -0.9 & 51.1 & 43.8 & 52.2 \\
\hline
\end{tabular}


Appendix 3. Monthly removal efficiencies for selected constituents as percentage of input load retained in Ellison Park wetland, Monroe County, N.Y., $1990-96$ (continued)

\begin{tabular}{|c|c|c|c|c|c|c|c|c|c|c|c|c|}
\hline \multirow[b]{2}{*}{$\begin{array}{l}\text { Month/ } \\
\text { year }\end{array}$} & \multicolumn{12}{|c|}{ Percent removal } \\
\hline & $\begin{array}{c}\text { Total } \\
\text { nitrogen }\end{array}$ & $\begin{array}{c}\text { Ammonia } \\
\text { plus organic } \\
\text { nitrogen }\end{array}$ & $\begin{array}{l}\text { Ammonia } \\
\text { nitrogen }\end{array}$ & $\begin{array}{l}\text { Organic } \\
\text { nitrogen }\end{array}$ & $\begin{array}{l}\text { Nitrate plus } \\
\text { nitrite }\end{array}$ & $\begin{array}{c}\text { Total } \\
\text { phosphorus }\end{array}$ & $\begin{array}{c}\text { Ortho- } \\
\text { phosphate }\end{array}$ & Chloride & Sulfate & $\begin{array}{c}\text { Total } \\
\text { suspended } \\
\text { solids }\end{array}$ & $\begin{array}{c}\text { Volatile } \\
\text { suspended } \\
\text { solids }\end{array}$ & $\begin{array}{c}\text { Nonvolatile } \\
\text { suspended } \\
\text { solids }\end{array}$ \\
\hline $1010 / 94$ & 1.9 & 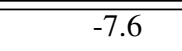 & 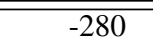 & 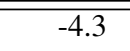 & 9.8 & 23.7 & -22.0 & 3.0 & 6.6 & 52.6 & 40.7 & 55.3 \\
\hline $11 / 94$ & 2.4 & -0.3 & -275 & 2.9 & 4.7 & 36.2 & -25.1 & 3.3 & 6.7 & 56.7 & 46.2 & 58.6 \\
\hline $12 / 94$ & 2.6 & 2.6 & -297 & 7.6 & 2.6 & 30.0 & -20.5 & -1.1 & 3.4 & 53.9 & 41.8 & 56.3 \\
\hline $1 / 95$ & 1.7 & 4.3 & -244 & 10.7 & 0.5 & 26.6 & -25.2 & -5.2 & 1.3 & 50.1 & 38.9 & 52.2 \\
\hline $2 / 95$ & 1.4 & -3.7 & -220 & 2.8 & 3.3 & 12.8 & -26.7 & -6.2 & 1.1 & 44.4 & 34.2 & 46.5 \\
\hline $3 / 95$ & 1.8 & -1.1 & -165 & 2.9 & 3.2 & 21.4 & -33.3 & -6.1 & 0.6 & 49.2 & 43.4 & 50.2 \\
\hline $4 / 95$ & 4.5 & -12.3 & -226 & -8.5 & 13.7 & 12.1 & -30.2 & -1.4 & 3.5 & 46.6 & 42.2 & 47.4 \\
\hline $5 / 95$ & 1.1 & -18.9 & -334 & -14.5 & 15.1 & 5.1 & -37.3 & -3.3 & 1.9 & 42.6 & 40.2 & 43.0 \\
\hline $6 / 95$ & 3.3 & -12.6 & -411 & -7.2 & 16.5 & 6.6 & -38.0 & -3.6 & 2.2 & 42.7 & 41.0 & 43.0 \\
\hline 7/95 & 7.6 & 0.5 & -379 & 5.9 & 14.0 & 16.1 & -38.4 & -4.5 & 2.1 & 48.4 & 46.0 & 48.8 \\
\hline $8 / 95$ & 4.3 & -2.1 & -375 & 3.3 & 9.7 & 17.8 & -35.3 & -4.7 & 3.3 & 47.3 & 43.4 & 48.0 \\
\hline 9/95 & 4.5 & -6.4 & -385 & -1.5 & 13.0 & 23.9 & -17.9 & 1.7 & 7.5 & 49.3 & 42.1 & 50.9 \\
\hline WY95 & 2.7 & -3.2 & -262 & 1.5 & 6.4 & 21.1 & -28.8 & -3.2 & 3.1 & 49.4 & 42.1 & 50.7 \\
\hline $10 / 95$ & 2.5 & 6.7 & -320 & 9.7 & -1.9 & 60.3 & -8.7 & -5.3 & 1.2 & 65.2 & 56.7 & 66.3 \\
\hline $11 / 95$ & -1.3 & -1.6 & -415 & 2.9 & -1.1 & 39.2 & -14.9 & -2.9 & 2.9 & 55.9 & 47.4 & 57.4 \\
\hline $12 / 95$ & -7.4 & -12.7 & -527 & -4.6 & -4.6 & 22.3 & -18.4 & -8.8 & -0.2 & 44.6 & 34.1 & 46.8 \\
\hline $1 / 96$ & 6.4 & 18.6 & -270 & 24.6 & -0.6 & 59.1 & -2.4 & -5.7 & 1.1 & 60.8 & 54.1 & 61.7 \\
\hline 2/96 & 0.7 & 4.9 & -271 & 11.6 & -1.0 & 38.9 & -15.8 & -8.7 & 0.2 & 51.5 & 46.0 & 52.3 \\
\hline $3 / 96$ & -1.1 & -3.7 & -259 & 1.4 & 0.2 & 30.1 & -24.7 & -9.4 & -0.5 & 48.4 & 46.6 & 48.6 \\
\hline $4 / 96$ & 10.8 & 8.5 & -236 & 11.7 & 12.3 & 51.6 & -9.7 & -0.8 & 4.4 & 59.7 & 59.5 & 59.7 \\
\hline $5 / 96$ & 17.1 & 14.6 & -284 & 17.7 & 19.2 & 56.9 & -3.2 & 3.3 & 7.1 & 63.4 & 63.4 & 63.4 \\
\hline $6 / 96$ & 18.7 & 16.7 & -379 & 21.0 & 20.5 & 45.8 & -12.5 & 3.3 & 7.9 & 60.0 & 61.5 & 59.8 \\
\hline 7/96 & 16.7 & 11.8 & -465 & 17.8 & 20.7 & 32.6 & -13.5 & 2.9 & 9.1 & 53.7 & 54.7 & 53.6 \\
\hline $8 / 96$ & 10.4 & 5.9 & -484 & 12.2 & 13.8 & 31.5 & -13.7 & -1.5 & 6.8 & 51.2 & 50.3 & 51.4 \\
\hline $9 / 96$ & 2.0 & -1.4 & -486 & 3.8 & 4.6 & 36.9 & -12.1 & -3.4 & 5.9 & 52.1 & 49.5 & 52.6 \\
\hline WY96 & 7.6 & 8.7 & -315 & 13.4 & 6.8 & 49.0 & -10.5 & -3.8 & 3.8 & 58.6 & 55.4 & 59.0 \\
\hline $\begin{array}{c}\text { Period of record } \\
1990-96\end{array}$ & 4.3 & 6.1 & -84.0 & 8.0 & 2.7 & 27.6 & -38.1 & -3.9 & 2.0 & 46.7 & 41.0 & 47.5 \\
\hline
\end{tabular}


Appendix 4. Chemical analyses of four sediment samples collected in Ellison Park wetland,Monroe County, N.Y., October 1994.

$[\mu \mathrm{g} / \mathrm{g}$, microgram per gram; $<63 \mathrm{U}$ or $<180 \mathrm{U} \mathrm{WS}$, material passing through a 63 - or 180-micrometer wet sieve, respectively; DW REC, dry weight recoverable; <, less than. SQ1 = Station 430951077312801. SQ2 = Station 430952077314001.

SQ3 = Station 431021077315901. Locations are shown in fig. 2.]

A. Major Elements, Trace Elements, and Carbon

\begin{tabular}{|c|c|c|c|c|c|c|c|c|}
\hline LOCAL & $\begin{array}{l}\text { ALUM- } \\
\text { INUM }\end{array}$ & $\begin{array}{l}\text { ANTI- } \\
\text { MONY }\end{array}$ & ARSENIC & BARIUM & $\begin{array}{l}\text { BERYL- } \\
\text { LIUM }\end{array}$ & BISMUTH & CADMIUM & CALCIUM \\
\hline $\begin{array}{l}\text { SITE } \\
\text { ID }\end{array}$ & $\begin{array}{c}<63 \text { US WS } \\
\text { ( PERCENT) }\end{array}$ & $\begin{array}{l}<63 \mathrm{U} \text { WS } \\
(\mu \mathrm{g} / \mathrm{g})\end{array}$ & $\begin{array}{l}<63 \mathrm{U} \text { WS } \\
(\mu \mathrm{g} / \mathrm{g})\end{array}$ & $\begin{array}{l}<63 \mathrm{U} \text { WS } \\
(\mu \mathrm{g} / \mathrm{g})\end{array}$ & $\begin{array}{l}<63 \mathrm{U} W \mathrm{~W} \\
(\mu \mathrm{g} / \mathrm{g})\end{array}$ & $\begin{array}{c}<180 \mathrm{U} \text { WS } \\
(\mu \mathrm{g} / \mathrm{g})\end{array}$ & $\begin{array}{c}<63 \mathrm{U} \text { WS } \\
(\mu \mathrm{g} / \mathrm{g})\end{array}$ & $\begin{array}{l}<63 \mathrm{U} \text { WS } \\
\text { ( PERCENT }\end{array}$ \\
\hline \multirow[t]{2}{*}{ SQ1 } & 5.0 & 0.4 & 4.9 & 460 & 1 & $<10$ & 0.9 & 6.4 \\
\hline & 5.0 & .5 & 5.1 & 460 & 1 & $<10$ & .7 & 6.6 \\
\hline SQ2 & 4.9 & .2 & 5.0 & 450 & 1 & $<10$ & .9 & 6.7 \\
\hline SQ3 & 4.8 & .6 & 3.9 & 470 & 1 & $<10$ & 3.8 & 4.7 \\
\hline
\end{tabular}

\begin{tabular}{|c|c|c|c|c|c|c|c|c|c|c|}
\hline $\mathrm{OC}$ & CERIUM & $\begin{array}{l}\text { CHRO- } \\
\text { MIUM }\end{array}$ & COBALT & COPPER & $\begin{array}{l}\text { EURO- } \\
\text { PIUM }\end{array}$ & GALLIUM & GOLD & MIUM & IRON & $\begin{array}{c}\text { LANTHA- } \\
\text { NUM }\end{array}$ \\
\hline $\begin{array}{l}\text { SITE } \\
\text { ID }\end{array}$ & $\begin{array}{l}<63 \mathrm{U} \text { WS } \\
(\mu \mathrm{g} / \mathrm{g})\end{array}$ & $\begin{array}{l}<63 \mathrm{U} \text { WS } \\
(\mu \mathrm{g} / \mathrm{g})\end{array}$ & $\begin{array}{l}<63 \mathrm{U} \text { WS } \\
(\mu \mathrm{g} / \mathrm{g})\end{array}$ & $\begin{array}{l}<63 \mathrm{U} \text { WS } \\
(\mu \mathrm{g} / \mathrm{g})\end{array}$ & $\begin{array}{l}<63 \mathrm{U} \text { WS } \\
(\mu \mathrm{g} / \mathrm{g})\end{array}$ & $\begin{array}{l}<63 \mathrm{U} \text { WS } \\
(\mu \mathrm{g} / \mathrm{g})\end{array}$ & $\begin{array}{l}<63 \mathrm{U} \text { WS } \\
(\mu \mathrm{g} / \mathrm{g})\end{array}$ & $\begin{array}{l}<63 \mathrm{U} \text { WS } \\
(\mu \mathrm{g} / \mathrm{g})\end{array}$ & $\begin{array}{c}<63 \text { U WS } \\
\text { (PERCENT) }\end{array}$ & $\begin{array}{c}<63 \mathrm{U} \text { WS } \\
(\mu \mathrm{g} / \mathrm{g})\end{array}$ \\
\hline
\end{tabular}

$\begin{array}{llllllllll}\text { SQ1 } & 45 & 43 & 11 & 41 & <2 & 11 & <8 & <4 & 2.7 \\ & 44 & 43 & 10 & 38 & <2 & 12 & <8 & <4 & 2.7 \\ \text { SQ2 } & 45 & 46 & 12 & 49 & <2 & 12 & <8 & <4 & 2.8 \\ \text { SQ3 } & 39 & 59 & 10 & 72 & <2 & 11 & <8 & <4 & 2.4\end{array}$

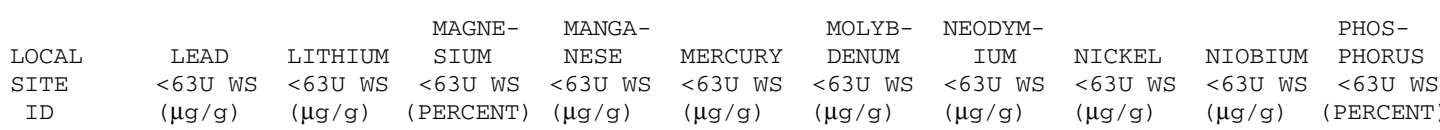

$\begin{array}{lllllllll}\text { SQ1 } & 44 & 30 & 1.4 & 880 & 0.11 & <2 & 25 & 19\end{array}$

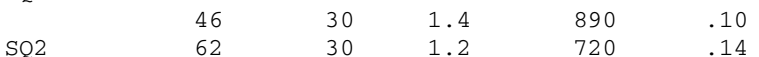

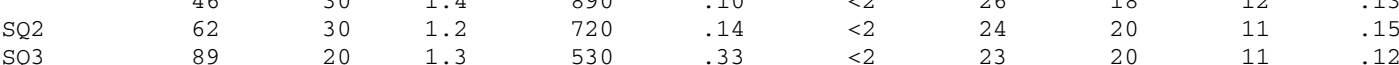

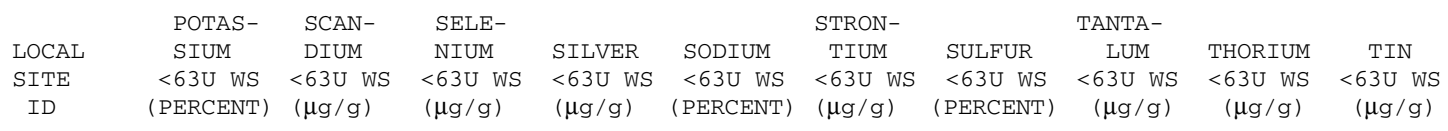

\begin{tabular}{|c|c|c|c|c|c|c|c|c|c|c|}
\hline SQ1 & 1.7 & 8 & 0.5 & 0.5 & 1.2 & 420 & 0.34 & $<40$ & 4.7 & $<10$ \\
\hline & 1.7 & 8 & .6 & .5 & 1.2 & 420 & .33 & $<40$ & 7.8 & $<10$ \\
\hline SQ2 & 1.6 & 8 & .8 & .7 & 1.1 & 440 & .60 & $<40$ & 6.5 & $<10$ \\
\hline SQ3 & 1.6 & 7 & .8 & 2.3 & 1.3 & 340 & .35 & $<40$ & 5.7 & $<10$ \\
\hline
\end{tabular}

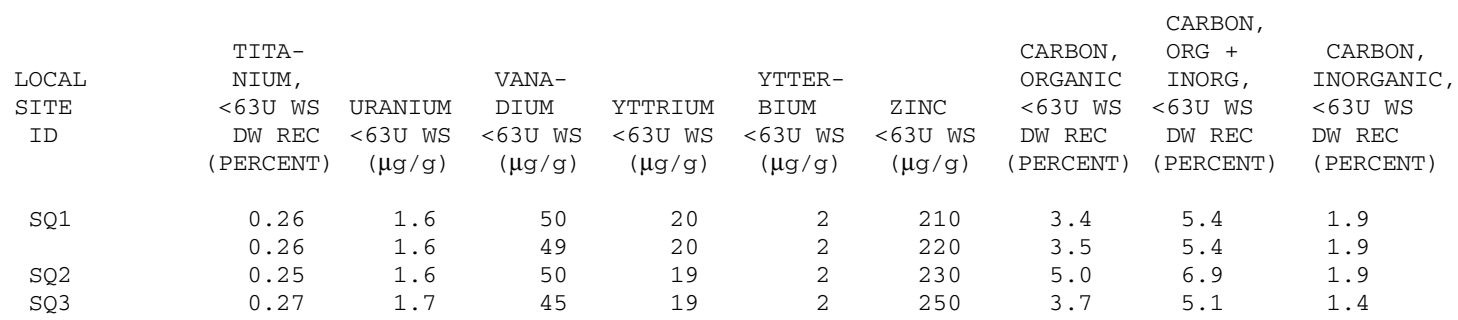


Appendix 4. Analyses of sediment samples collected in the Ellison Park wetland, Monroe County, N.Y., October 1994 (continued)

\section{B. Polycyclic aromatic hydrocarbons}

\begin{tabular}{|c|c|c|c|c|c|c|c|c|c|c|}
\hline LOCAL & $\begin{array}{l}\text { PARA- } \\
\text { CHLORO- } \\
\text { META }\end{array}$ & $\begin{array}{c}2- \\
\text { CHLORO- }\end{array}$ & $\begin{array}{l}2,4 \text {-DI- } \\
\text { CHLORO- }\end{array}$ & & $\begin{array}{l}\text { 4,6- } \\
\text { DINITRO } \\
\text {-ORTHO- }\end{array}$ & $\begin{array}{c}2,4- \\
\text { DI- } \\
\text { NITRO- }\end{array}$ & $\begin{array}{c}2- \\
\text { NITRO- }\end{array}$ & $\begin{array}{c}4- \\
\text { NITRO- }\end{array}$ & $\begin{array}{r}\text { PENTA- } \\
\text { CHLORO- }\end{array}$ & $\begin{array}{l}\text { PHENOL } \\
\left(\mathrm{C}_{6} \mathrm{H}_{5}\right.\end{array}$ \\
\hline $\begin{array}{l}\text { SITE } \\
\text { ID }\end{array}$ & $\begin{array}{l}\text { CRESOL } \\
(\mu \mathrm{g} / \mathrm{kg})\end{array}$ & $\begin{array}{l}\text { PHENOL } \\
(\mu \mathrm{g} / \mathrm{kg})\end{array}$ & $\begin{array}{l}\text { PHENOL } \\
(\mu \mathrm{g} / \mathrm{kg})\end{array}$ & $\begin{array}{l}2,4-\mathrm{DP} \\
(\mu \mathrm{g} / \mathrm{kg})\end{array}$ & $\begin{array}{l}\text { CRESOL } \\
(\mu \mathrm{g} / \mathrm{kg})\end{array}$ & $\begin{array}{l}\text { PHENOL } \\
(\mu \mathrm{g} / \mathrm{kg})\end{array}$ & $\begin{array}{l}\text { PHENOL } \\
(\mu \mathrm{g} / \mathrm{kg})\end{array}$ & $\begin{array}{l}\text { PHENOL } \\
(\mu \mathrm{g} / \mathrm{kg})\end{array}$ & $\begin{array}{l}\text { PHENOL } \\
(\mu \mathrm{g} / \mathrm{kg})\end{array}$ & $\begin{array}{c}-\mathrm{OH}) \\
(\mu \mathrm{g} / \mathrm{kg})\end{array}$ \\
\hline \multirow[t]{2}{*}{ SQ1 } & $<600$ & $<200$ & $<200$ & $<200$ & $<600$ & $<600$ & $<200$ & $<600$ & $<600$ & $<200$ \\
\hline & $<600$ & $<200$ & $<200$ & $<200$ & $<600$ & $<600$ & $<200$ & $<600$ & $<600$ & $<200$ \\
\hline SQ2 & $<600$ & $<200$ & $<200$ & $<200$ & $<600$ & $<600$ & $<200$ & $<600$ & $<600$ & $<200$ \\
\hline SQ3 & $<600$ & $<200$ & $<200$ & $<200$ & $<600$ & $<600$ & $<200$ & $<600$ & $<600$ & $<200$ \\
\hline
\end{tabular}

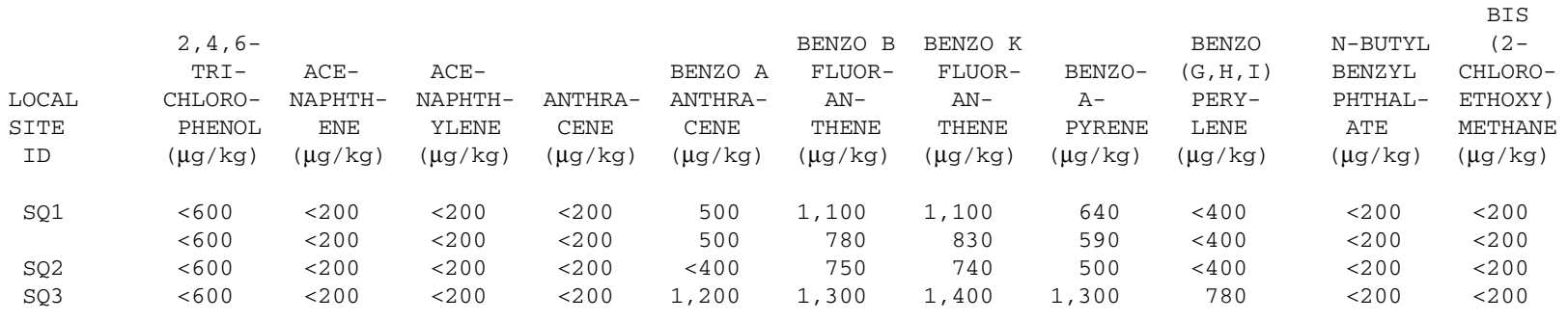

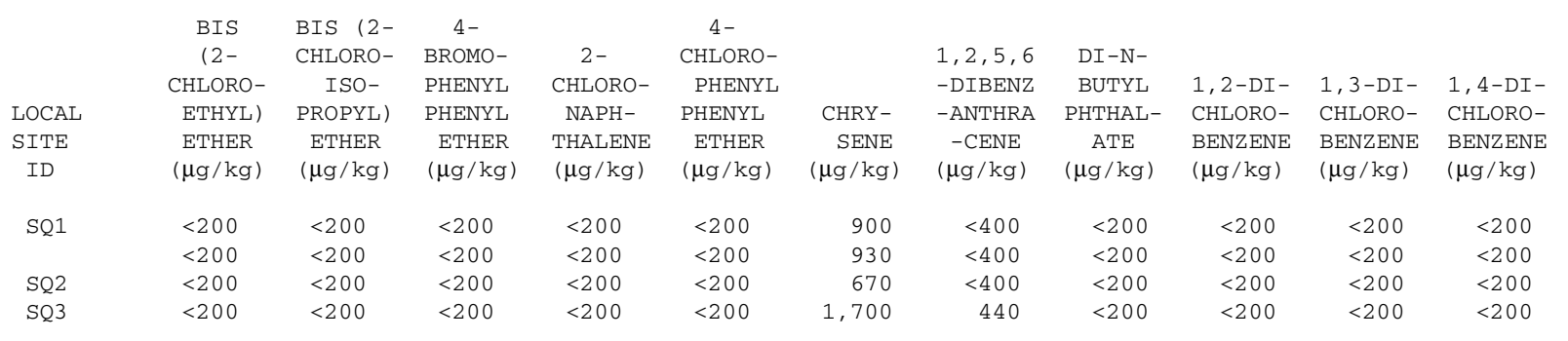

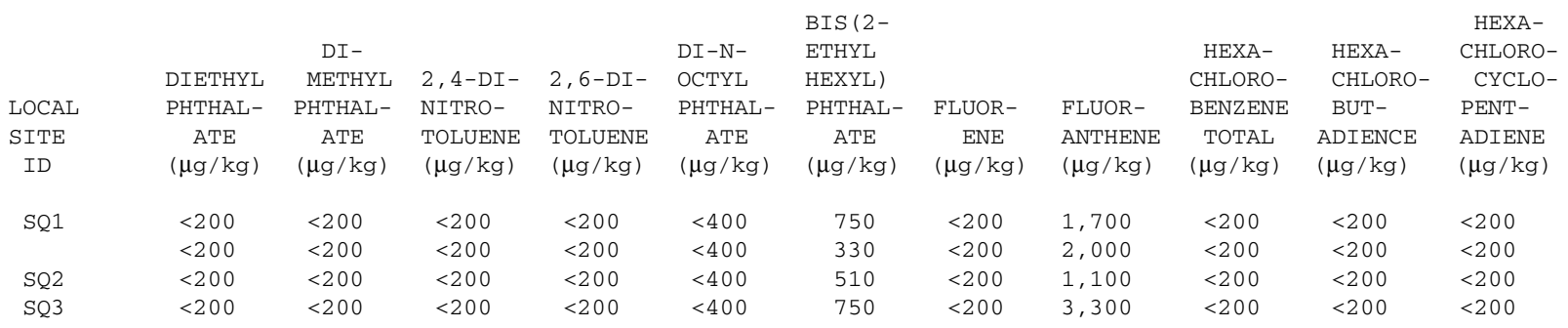

\begin{tabular}{|c|c|c|c|c|c|c|c|c|c|c|c|}
\hline $\begin{array}{l}\text { LOCAL } \\
\text { SITE } \\
\text { ID }\end{array}$ & $\begin{array}{c}\text { HEXA- } \\
\text { CHLORO- } \\
\text { ETHANE } \\
(\mu \mathrm{g} / \mathrm{kg})\end{array}$ & $\begin{array}{l}\text { INDENO } \\
(1,2,3- \\
\text { CD }) \\
\text { PYRENE } \\
(\mu \mathrm{g} / \mathrm{kg})\end{array}$ & $\begin{array}{l}\text { ISO- } \\
\text { PHORONE } \\
(\mu \mathrm{g} / \mathrm{kg})\end{array}$ & $\begin{array}{c}\text { NAPHTH- } \\
\text { ALENE } \\
(\mu \mathrm{g} / \mathrm{kg})\end{array}$ & $\begin{array}{l}\text { NITRO- } \\
\text { BENZENE } \\
(\mu \mathrm{g} / \mathrm{kg})\end{array}$ & $\begin{array}{c}\text { N-NITRO } \\
\text {-SODI- } \\
\text { METHY- } \\
\text { LAMINE } \\
(\mu \mathrm{g} / \mathrm{kg})\end{array}$ & $\begin{array}{c}\text { N-NITRO } \\
\text {-SODI- } \\
\text { PHENY- } \\
\text { LAMINE } \\
(\mu \mathrm{g} / \mathrm{kg})\end{array}$ & $\begin{array}{c}\text { N-NITRO- } \\
\text { SODI-N- } \\
\text { PROPYL- } \\
\text { AMINE } \\
(\mu \mathrm{g} / \mathrm{kg})\end{array}$ & $\begin{array}{l}\text { PHENAN- } \\
\text { THRENE } \\
(\mu \mathrm{g} / \mathrm{kg})\end{array}$ & $\begin{array}{l}\text { PYRENE } \\
(\mu \mathrm{g} / \mathrm{kg})\end{array}$ & $\begin{array}{c}1,2,4- \\
\text { TRI- } \\
\text { CHLORO- } \\
\text { BENZENE } \\
(\mu \mathrm{g} / \mathrm{kg})\end{array}$ \\
\hline \multirow[t]{2}{*}{ SQ1 } & $<200$ & $<400$ & $<200$ & $<200$ & $<200$ & $<200$ & $<200$ & $<200$ & 580 & 1,300 & $<200$ \\
\hline & $<200$ & $<400$ & $<200$ & $<200$ & $<200$ & $<200$ & $<200$ & $<200$ & 880 & 1,500 & $<200$ \\
\hline SQ2 & $<200$ & $<400$ & $<200$ & $<200$ & $<200$ & $<200$ & $<200$ & $<200$ & 320 & 850 & $<200$ \\
\hline $\mathrm{SQ3}$ & $<200$ & 720 & $<200$ & $<200$ & $<200$ & $<200$ & $<200$ & $<200$ & 1,700 & 2,900 & $<200$ \\
\hline
\end{tabular}


Appendix 4. Analyses of sediment samples collected in the Ellison Park wetland, Monroe County, N.Y., October 1994 (continued).

\begin{tabular}{|c|c|c|c|c|c|c|c|c|c|}
\hline \multicolumn{10}{|c|}{ C. Organochlorine compounds } \\
\hline $\begin{array}{l}\text { LOCAL } \\
\text { SITE } \\
\text { ID }\end{array}$ & & $\begin{array}{l}\text { ALDRIN, } \\
\text { TOTAL } \\
(\mu \mathrm{g} / \mathrm{kg})\end{array}$ & $\begin{array}{l}\text { CHLOR- } \\
\text { DANE, } \\
\text { TOTAL } \\
(\mu \mathrm{g} / \mathrm{kg})\end{array}$ & $\begin{array}{c}\mathrm{P}, \mathrm{P}^{\prime}- \\
\mathrm{DDD}, \\
\mathrm{RECOVER} \\
(\mu \mathrm{g} / \mathrm{kg})\end{array}$ & $\begin{array}{c}\mathrm{P}, \mathrm{P}^{\prime}- \\
\mathrm{DDE}, \\
\mathrm{RECOVER} \\
(\mu \mathrm{g} / \mathrm{kg})\end{array}$ & $\begin{array}{c}\mathrm{P}, \mathrm{P}^{\prime}- \\
\mathrm{DDT}, \\
\mathrm{RECOVER} \\
(\mu \mathrm{g} / \mathrm{kg})\end{array}$ & $\begin{array}{l}\quad \text { DI - } \\
\text { ELDRIN } \\
\text { TOTAL } \\
(\mu \mathrm{g} / \mathrm{kg})\end{array}$ & $\begin{array}{l}\text { ENDO- } \\
\text { SULFAN, } \\
\text { TOTAL } \\
(\mu \mathrm{g} / \mathrm{kg})\end{array}$ & $\begin{array}{l}\text { ENDRIN, } \\
\text { TOTAL } \\
(\mu \mathrm{g} / \mathrm{kg})\end{array}$ \\
\hline $\begin{array}{l}\text { SQ1 } \\
\text { SQ2 } \\
\text { SQ3 }\end{array}$ & & $\begin{array}{l}<0.1 \\
<0.1 \\
<0.2 \\
<0.1\end{array}$ & $\begin{array}{l}22 \\
19 \\
18 \\
26\end{array}$ & $\begin{array}{l}3.8 \\
3.1 \\
4.5 \\
6.5\end{array}$ & $\begin{array}{l}7.1 \\
6.2 \\
8.4 \\
7.4\end{array}$ & $\begin{array}{r}1.0 \\
.9 \\
.6 \\
.8\end{array}$ & $\begin{array}{l}2.3 \\
1.8 \\
1.2 \\
3.5\end{array}$ & $\begin{array}{l}<0.1 \\
<0.1 \\
<0.2 \\
<0.1\end{array}$ & $\begin{array}{l}<0.8 \\
<0.8 \\
<1.6 \\
<0.8\end{array}$ \\
\hline $\begin{array}{l}\text { LOCAL } \\
\text { SITE } \\
\text { ID }\end{array}$ & $\begin{array}{l}\text { HEPTA- } \\
\text { CHLOR } \\
\text { EPOXIDE, } \\
\text { TOTAL } \\
(\mu \mathrm{g} / \mathrm{kg})\end{array}$ & $\begin{array}{l}\text { HEPTA- } \\
\text { CHLOR, } \\
\text { TOTAL } \\
(\mu \mathrm{g} / \mathrm{kg})\end{array}$ & $\begin{array}{l}\text { LINDANE, } \\
\text { TOTAL } \\
(\mu \mathrm{g} / \mathrm{kg})\end{array}$ & $\begin{array}{l}\text { METH- } \\
\text { OXY- } \\
\text { CHLOR, } \\
\text { TOTAL } \\
(\mu \mathrm{g} / \mathrm{kg})\end{array}$ & $\begin{array}{l}\text { MIREX, } \\
\text { TOTAL } \\
(\mu \mathrm{g} / \mathrm{kg})\end{array}$ & $\begin{array}{l}\text { PER- } \\
\text { THANE, } \\
\text { TOTAL } \\
(\mu \mathrm{g} / \mathrm{kg})\end{array}$ & $\begin{array}{l}\text { TOXA- } \\
\text { PHENE, } \\
\text { TOTAL } \\
(\mu \mathrm{g} / \mathrm{kg})\end{array}$ & $\begin{array}{l}\text { PCB, } \\
\text { TOTAL } \\
(\mu \mathrm{g} / \mathrm{kg})\end{array}$ & $\begin{array}{l}\text { PCN } \\
\text { TOTAL } \\
(\mu \mathrm{g} / \mathrm{kg})\end{array}$ \\
\hline $\begin{array}{l}\text { SQ1 } \\
\text { SQ2 } \\
\text { SQ3 }\end{array}$ & $\begin{array}{l}<0.8 \\
<0.8 \\
<1.6 \\
<0.8\end{array}$ & $\begin{array}{l}<0.1 \\
<0.1 \\
<0.2 \\
<0.1\end{array}$ & $\begin{array}{l}<0.1 \\
<0.1 \\
<0.2 \\
<0.1\end{array}$ & $\begin{array}{l}<32 \\
<26 \\
<24 \\
<38\end{array}$ & $\begin{array}{l}<0.1 \\
<0.1 \\
<0.2 \\
<0.1\end{array}$ & $\begin{array}{l}<1 \\
<1 \\
<2 \\
<1\end{array}$ & $\begin{array}{l}<10 \\
<10 \\
<20 \\
<10\end{array}$ & $\begin{array}{l}28 \\
25 \\
43 \\
52\end{array}$ & $\begin{array}{l}<1.0 \\
<1.0 \\
<2.0 \\
<1.0\end{array}$ \\
\hline
\end{tabular}

